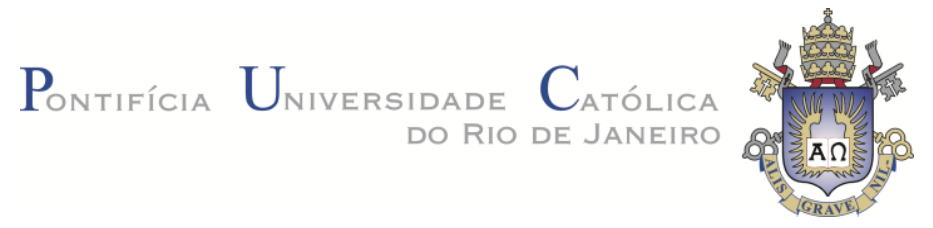

Ilona Becskeházy

\title{
A formação de redes escolares no Estado de São Paulo: Em busca de padrões de qualidade e equidade
}

Dissertação de Mestrado

Dissertação apresentada como requisito parcial para obtenção do grau de Mestre em Educação do Departamento de Educação do Centro de Teologia e Ciências Humanas da PUC-Rio.

Orientador: Prof. Fátima Cristina de Mendonça Alves

Rio de Janeiro

Março de 2014 


\title{
Pontifícia Universidade Católica $_{\text {a }}$

llona Becskeházy

\section{A formação de redes escolares no Estado de São Paulo:}

Em busca de padrões de qualidade e equidade

\begin{abstract}
Dissertação apresentada como requisito parcial para obtenção do grau de Mestre em Educação do Departamento de Educação do Centro de Teologia e Ciências Humanas da PUC-Rio. Aprovada pela Comissão Examinadora abaixo assinada.
\end{abstract}

Prof. Fátima Cristina de Mendonça Alves

Orientadora

Departamento de Educação - PUC-Rio

Prof. Cynthia Paes de Carvalho Departamento de Educação - PUC-Rio

Prof. Romualdo Portela USP

Prof. Denise Berruezo Portinari Coordenadora Setorial doCentro de Teologia e Ciências Humanas PUC-Rio

Rio de Janeiro, 31 de março de 2014 
Todos os direitos reservados. É proibida a reprodução total ou parcial do trabalho sem autorização da universidade, da autora e do orientador.

\section{llona Becskeházy}

Bacharel em Nutrição pela Universidade Federal do Rio de Janeiro (1990) com Especialização em Administração de Empresas pela Escola de Administração de Empresas da Fundação Getúlio Vargas de São Paulo. Dirigiu de 1996 a 2011 várias instituições sem fins lucrativos, com projetos na área de educação. É colunista do Boletim Missão Aluno da Rádio CBN e da Revista Gestão Educacional.

Ficha Catalográfica

Becskeházy, llona

A formação de redes escolares no estado de São Paulo: em busca de padrões de qualidade e equidade / Ilona Becskeházy ; orientadora: Fátima Cristina de Mendonça Alves. - 2014.

155 f. : il. (color.) ; $30 \mathrm{~cm}$

Dissertação (mestrado) - Pontifícia Universidade Católica do Rio de Janeiro, Departamento de Educação, 2014.

Inclui bibliografia

1. Educação - Teses. 2. Descentralização. 3. Municipalização. 4. São Paulo. 5. Qualidade. 6. Equidade. I. Alves, Fátima Cristina de Mendonça. II. Pontifícia Universidade Católica do Rio de Janeiro. Departamento de Educação. III. Título. 
Ao meu marido, Manuel, e à nossa filha Ritinha, de cujas companhias me privei para produzir este trabalho, mas cujas existências são minhas principais fontes de inspiração. 


\section{Agradecimentos}

À Capes - Coordenadoria de Aperfeiçoamento de Pessoal de Nível Superior, por meio do Programa de Excelência Acadêmica (Proex), no ano de 2012/13

e à

Faperj - Fundação Carlos Chagas Filho de Amparo à Pesquisa do Estado do Rio de Janeiro, por meio do programa "Bolsa Nota 10" no ano de 2013/14, pelos recursos que tornaram possível a execução deste trabalho.

Aos Professores do Departamento de Educação da Puc-Rio, com quem aprendi muito durante o Programa de Mestrado, em particular à minha Orientadora, Professora Fátima Alves, que me mostrou o caminho das pedras não só para absorver o máximo de conhecimento durante todo o percurso, mas especificamente para desenhar e produzir esta pesquisa. Agradeço especialmente à Professora Cynthia Paes de Carvalho, com quem tive uma emocionante e educativa experiência de estágio supervisionado, além das ótimas dicas para o projeto, e à Professora Mariane Koslinski, da Faculdade de Educação da UFRJ, que nos proporcionou um curso desafiante de Sociologia e Desigualdades Educacionais com a Professora Fátima Alves.

À Professora Lorena Barberia do Departamento de Ciências Políticas da Faculdade de Filosofia, Letras e Ciências Humanas da USP, que me aceitou como aluna especial e me permitiu fazer as pazes com a Estatística, mesmo com todas as dificuldades que tive. Ao Professor Romualdo Portela, da Faculdade de Educação da USP, que também me aceitou como aluna em seu concorrido curso de Política Educacional, dando-me a oportunidade de ler e discutir obras da maior importância para minha formação.

À querida amiga Paula Louzano que segura a minha mão nas horas difíceis e ilumina minhas idéias com sua inteligência, competência e ótimo humor. 
À Ana Maria Mantovani, Coordenadora do Centro de Gerenciamento da Municipalização do Ensino da Secretaria de Educação do Estado de São Paulo, pela disponibilização das informações do Projeto de Avaliação dos Sistemas Municipais de Ensino Fundamental, elaborado pela Fundação do Desenvolvimento Administrativo (Fundap).

Às Professoras Guiomar Namo de Mello e Maria Helena Guimarães de Castro pelas ótimas referências bibiográficas e apoio moral.

Aos colegas do Observatório da Educação, que mostraram a infinidade de temas a se pesquisar e debater, em particular ao André Regis, que me ensinou os primeiros passos no SPSS.

À minha prima Ana Caillaux que, com muita paciência, me fez progredir no entendimento das bases de dados e do SPSS.

Na Faculdade de Filosofia, Letras e Ciências Humanas da USP, agradeço ao Paulo Loyola, que não só ajudou com as primeiras bases de dados, mas foi um ótimo tutor de STATA e ao Leonardo Sangali Barone, que me emprestou seu genial curso autoinstrutivo do mesmo pacote estatístico.

Aos pacientes funcionários do Departamento de Educação da Puc-Rio, que resolvem nossas dificuldades a todo momento. 


\section{Resumo}

Becskeházy, Ilona; Alves, Fátima Cristina de Mendonça. A formação de redes escolares no Estado de São Paulo: Em busca de padrões de qualidade e equidade. Rio de Janeiro, 2014. 155p. - Departamento de Educação, Pontifícia Universidade Católica do Rio de Janeiro.

O objetivo do trabalho é compreender se o processo de descentralização das matrículas do ensino fundamental do Estado de São Paulo para seus municípios se deu de forma a contribuir para o binômio qualidade-equidade e em que tipo de contexto local. Por meio da categorização dos municípios em termos de seu estágio de municipalização e da confrontação dessa variável dependente com características dos municípios, procurou-se verificar perfis sistemáticos no ritmo de descentralização e de evolução de desempenho das escolas. A unidade de análise é o município, os critérios de diferenciação entre eles são o tamanho da população, riqueza e renda locais e a Região Administrativa do Governo em que se localizam. A pesquisa identificou, entre outros, dois grupos com comportamento oposto: os que municipalizaram totalmente a rede nas duas etapas do ensino fundamental e obtém resultados progressivamente melhores e os que optaram por manter a maior parte das escolas em nível estadual e apresentam mais lentidão em avançar seus indicadores de performance. Além disso, utilizou as variáveis estudadas para propor um indicador complementar ao IDEB que explicita as diferenças de contexto entre municípios.

\section{Palavras-chave}

Descentralização; Municipalização; São Paulo; Qualidade; Equidade 


\section{Abstract}

Becskeházy, Ilona; Alves, Fátima Cristina de Mendonça (Advisor). The structuring of school networks in the State of São Paulo: in search of patterns of quality and equity. Rio de Janeiro, 2014. 155p. Msc. Dissertation - Departamento de Educação, Pontifícia Universidade Católica do Rio de Janeiro.

The work aims at grasping if, in the State of São Paulo, the process of decentralizing public education services in primary and lower secondary schools from the state level to its municipalities contributed to the binomial of qualityequity and in which type of local context. By categorizing the municipalities in terms of their decentralization processes and confronting this dependent variable with local characteristics, the research tried to find systematic profiles of municipalization rhythm and performance evolution at school level. The unit of analysis is the municipality, and the criteria to differentiate them are their population size, local wealth production and income, and the administrative region they belong to. The work identified, among others, two groups of municipalities with opposing profiles: one that controls enrollments both at primary and lower secondary schools which is consistently improving performance indicators, and another, which opted to maintain the majority of enrollments at the state level, and is lagging to advance proficiency performance. In addition, the variables were combined to propose an index to complement the official IDEB and make the differences between municipalities more explicit.

\section{Keywords}

Descentralization; Municipalization; São Paulo; Quality; Equity 


\section{Sumário}

$\begin{array}{ll}\text { 1. Introdução } & 17\end{array}$

2. Objetivos, hipóteses e metodologia da pesquisa 23

3. Referencial teórico sobre descentralização na educação 27

4. O contexto educacional brasileiro 57

4.1 Descrição da estrutura da oferta de educação 57

4.2 Expansão rápida e recente das matrículas: uma corrida contra o tempo

4.3 A avaliação em larga escala como parte essencial da evolução educacional recente no Brasil

5. O contexto educacional paulista

5.1 Ritmo de evolução da distribuição das matrículas 81

5.2 População e matrícula por dependência administrativa 94

5.3 Ritmo de evolução de desempenho por dependência administrativa

6. Identificação de grupos similares de municípios 111

6.1 A construção das variáveis independentes 111

7. Análise dos grupos identificados 121

8. Indicador complementarr para comparar municípios 130

9. Perspectivas futuras e conclusões 134

10. Referências Bibliográficas 139

11. Anexos 149 


\section{Lista de tabelas}

Tabela 1: Municípios analisados por Lucio (2005) e características dos processos de municipalização

Tabela 2: Municípios analisados por Lucio (2005) e condições de implementação da política pública

Tabela 3: Etapas de ensino - idade correspondente, denominação, marco legal, matrícula líquida e meta PNE

Tabela 4: Distribuição das matrículas por dependência administrativa e etapa -Brasil (2011)

Tabela 5: Distribuição das matrículas por dependência administrativa e etapa -São Paulo (2011)

Tabela 6: Evolução da população de 1980 a 2010 e projeção para 2020, por faixas etárias selecionadas - Brasil

Tabela 7 : Evolução das matrículas totais de 1980 a 2010 e projeção de acordo com o Plano Nacional de Educação, por etapa de ensino - Brasil

Tabela 8:São Paulo - Evolução das matrículas totais de 1980 a 2010 e projeção de acordo com o Plano Nacional de Educação, por etapa de ensino

Tabela 9: Gajardo, 1999 - Eixos e estratégias nas orientações de política educacional na década de 1990

Tabela 10: OCDE - Categorias de decisão autônoma em gestão educacional

Tabela 11: Evolução do número de municípios por faixa de municipalização nos anos iniciais do ensino fundamental (19962012)

Tabela 12: Evolução do número de municípios por faixa de municipalização nos anos finais do ensino fundamental (19962012) 
Tabela 13: Distribuição do número de municípios com rede própria por faixa de municipalização (1996/2012)

Tabela 14: Matriz de correlação entre PIB percapita municipal, renda das famílias e nível de educação dos residentes adultos

Tabela 15: Cobertura populacional da educação básica no Estado de São Paulo (2010)

Tabela 16: Distribuição da população no Estado de São Paulo por patamar de população residente* nos municípios (2010)

Tabela 17: Distribuição das matrículas de ensino fundamental no Estado de São Paulo por patamar de matrículas nos municípios (2010)

Tabela 18: Sumário estatístico - evolução ldeb $5^{\circ}$ ano - rede estadual e redes municipais

Tabela 19: Sumário estatístico - evolução Ideb $5^{\circ}$ ano - rede estadual e redes municipais

Tabela 20: Classificação de nível de renda do Banco Mundial traduzida para o contexto de São Paulo

Tabela 21: Categorias de PIB percapita e distribuição no Estado de São Paulo

Tabela 22: Sumário estatístico despesa percapita na função educação no ensino fundamental e PIB percapita

Tabela 23: Distribuição da população residente com 10 anos ou mais por faixa de rendimento mensal nominal em Salários Mínimos

Tabela 24: Classificação e distribuição dos municípios pelo seu percentual de domicílios por faixa de rendimento mensal nominal em Salários Mínimos

Tabela 25: Classificação e distribuição dos municípios e população pelas Regiões Administrativas do Estado

Tabela 26: Distribuição percentual dos municípios pelas Regiões Administrativas do estado por nível de municipalização

Tabela 27: Sumário estatístico - percentual de matrículas na rede particular - anos iniciais e finais em 1996 e em 2012 
Tabela 28: Cálculo do indicador proposto - anos inciais

Tabela 29: Cálculo do indicador proposto - anos finais ............................. 132

Tabela 30: Exemplo de ranking por Ideb - anos inciais ............................ 132

Tabela 31: Exemplo de ranking pelo indicador proposto - anos iniciais 


\section{Lista de gráficos}

Gráfico 1: Distribuição das matrículas estaduais e municipais, Brasil, Regiões e estados da Região Sudeste (2011)

Gráfico 2: Evolução da população de 1980 a 2013, com projeção para 2020, por faixas etárias selecionadas - São Paulo 66

Gráfico 3: Evolução da matrícula bruta no ensino secundário (19701990-2010*) - países do G-20 + América do Sul e México 68

Gráfico 4: Taxa de distorção idade-série (\%) Brasil, Regiões e estados do Sudeste (2012)

Gráfico 5: Número de aulas aula-dia por etapa de ensino - Regiões do Brasil e Estado de São Paulo

Gráfico 6: Evolução comparativa dos resultados no PISA desde 2000 - G20

Gráfico 7: Evolução das matrículas da educação básica no Estado de São Paulo por dependência administrativa (1991, 1996, 20002011)

Gráfico 8 A e B: Evolução da municipalização no Estado de São Paulo - anos iniciais e finais (1996 - 2012).

Gráfico 9: Comparação da distribuição dos municípios pelo \% de municipalização nos anos iniciais com o nível de PIB percapita (1996 e 2000) 91

Gráfico 10: Comparação da distribuição dos municípios pelo \% de municipalização nos anos iniciais com o nível de PIB percapita (2005 e 2012)

Gráfico 11: Comparação da distribuição dos municípios pelo \% de municipalização nos anos iniciais com o \% de renda domiciliar acima de 2SM (1996 e 2000) 93

Gráfico 12: Comparação da distribuição dos municípios pelo \% de municipalização nos anos iniciais com o \% de renda domiciliar acima de 2SM (2005 e 2012) 
Gráfico 13: Evolução das matrículas totais da educação básica e da população total de 0 a 19 anos no Estado de São Paulo (1991, 1996, 2000-2011)

Gráfico 14: Evolução da matrícula no ensino fundamental no Estado de São Paulo por dependência administrativa (1991, 1996, 2000-2011)

Gráfico 15 A e B: Comparação da distribuição dos municípios pelo $\%$ de municipalização nos anos iniciais com o tamanho de sua população (1996 e 2000)

Gráfico 16: Fórmula de cálculo do IDEB 100

Gráfico 17: Evolução Ideb - 5o ano - Rede estadual (2) e redes municipais (2)

Gráfico 18: Evolução Ideb - 9o Ano - Rede estadual (2) e redes municipais (2) 102

Gráfico 19: Comparação da evolução do IDEB de 5ํan ano na rede estadual com o conjunto das redes municipais por nível de renda domiciliar dos municípios

Gráfico 20: Evolução do percentual de matrículas nas redes particulares dos municípios por nível de renda dos domicílios 105

Gráfico 21: Média por escola de proficiência em Língua Portuguesa 2011 - por nível de renda familiar (de 1 a 5) e tipo de rede (2 ou 3) 106

Gráfico 22: Média por escola de proficiência em Língua Portuguesa 2011 - por nível de renda familiar (de 1 a 5) e tipo de rede (2 ou 3) 107

Gráfico 23: Evolução da média de proficiência em Língua Portuguesa por escola - mesma coorte - por nível de renda familiar (de 1 a 5 ) e tipo de rede (2 ou 3). 108

Gráfico 24: Taxa de distorção idade-série nos anos iniciais - por nível de renda familiar (de 1 a 5) e tipo de rede (2 ou 3). 109

Gráfico 25: Taxa de distorção idade-série nos anos finais - por nível de renda familiar (de 1 a 5 ) e tipo de rede (2 ou 3 )..... 109

Gráfico 26 A e B: Comparação da taxa de municipalização por RA início (1996) e dado mais recente do processo de municipalização (2012)

Gráfico 27 A e B: Evolução da taxa de municipalização por nível de renda - anos iniciais e anos finais - GRUPO 1 
Gráfico 28: Evolução da taxa de municipalização por nível de renda - anos iniciais- GRUPO 2

Gráfico 29 A a E: Evolução da média de proficiência por escola em Língua Portuguesa para cada GRUPO de interesse, por etapa de ensino e nível de renda 


\section{Lista de siglas}

APEOESP - Sindicato dos Professores do Ensino Oficial do Estado de São Paulo

APM - Associação de Pais e Mestres

BM - Banco Mundial

CACS - Conselhos de Acompanhamento e Controle Social

CAPES - Coordenação de Aperfeiçoamento de Pessoal de Nível

Superior

CEPAL - Comissão Econômica para a América Latina e Caribe

(CEPAL)

CF - Constituição Federal

CME - Conselho Municipal de Educação

CNE - Conselho Nacional de Educação

$\mathrm{CTCH}$ - Centro de Teologia e Ciências Humanas

DF - Distrito Federal

EC - Emenda Constitucional

EF - Ensino Fundamental

El - Educação Infantil

EJA - Educação para Jovens e Adultos

EM - Escola Municipal

FFLCH - Faculdade de Filosofia, Letras e Ciências Humanas

FIFA - Fédération Internationale de Football Association

FNDE - Fundo Nacional de Desenvolvimento da Educação

FUNDAP - Fundação do Desenvolvimento

FUNDEB - Fundo de Manutenção e Desenvolvimento da Educação

Básica e de Valorização dos Profissionais da Educação

FUNDEF - Fundo de Manutenção e Desenvolvimento do Ensino

Fundamental e de Valorização do Magistério

HTPC - Horas de Trabalho Pedagógico Coletivo

IBGE - Instituto Brasileiro de Geografia e Estatística

IDEB - Índice de Desenvolvimento da Educação Básica

IDH - Índice de Desenvolvimento Humano

IES - Instituição de Educação Superior

INEP - Instituto Nacional de Estudos e Pesquisas Educacionais

IPEA - Instituto de Pesquisa Econômica Aplicada

IPRS - Índice Paulista de Responsabilidade Social

LC - Lei Complementar

LDB - Lei de Diretrizes e Bases

LDBEN - Lei de Diretrizes e Bases da Educação Nacional

MEC - Ministério da Educação e Cultura

NEPP - Núcleo de Estudos e Práticas Pedagógicas

OCDE - Organização de Cooperação e Desenvolvimento Econômico 
OEA - Organização dos Estados Americanos

ONG - Organização Não Governamental

PCN - Parâmetros Curriculares Nacionais

PCP - Professor Coordenador Pedagógico

PDDE - Programa Dinheiro Direto na Escola

PDE - Plano de Desenvolvimento da Educação

PIB - Produto Interno Bruto

PISA - Programa Internacional de Avaliação de Estudantes

PME - Plano Municipal de Educação

PNE - Plano Nacional de Educação

PNLD - Programa Nacional do Livro Didático

PNUD - Plano das Nações Unidas para o Desenvolvimento

PREAL - Programa Para Reforma Educacional na América Latina e

Caribe

ProUni - Programa Universidade para Todos

RMC - Região Metropolitana de Campinas

SAEB - Sistema de Avaliação da Educação Básica

SARESP - Sistema de Avaliação do Rendimento Escolar do Estado de

São Paulo

SEADE - Sistema Estadual de Análise de Dados Estatísticos

SEB - Secretaria de Educação Básica

SEESP - Secretaria da Educação do Estado de São Paulo

SIOPE - Sistema de Informações sobre Orçamentos Públicos em

Educação

SME - Secretaria Municipal de Educação

TALIS - Pesquisa Internacional sobre Ensino e Aprendizagem

UNESCO - Organização das Nações Unidas para a Educação, a

Ciência e a Cultura

UNESP - Universidade Estadual Paulista

UNICAMP - Universidade Estadual de Campinas

UNICEF - Fundo das Nações Unidas para a Infância

USP - Universidade de São Paulo 


\section{Introdução}

Os indicadores educacionais brasileiros têm apresentado melhoras históricas nas últimas décadas: acesso e cobertura atingiram proporções jamais alcançadas até então, principalmente para as camadas mais pobres da população e comunidades mais isoladas, ao mesmo tempo que infraestrutura, desempenho, conclusão e equidade, mesmo ainda inspirando inquietação, também apresentaram sensível evolução positiva.

Essa transformação é consequência da implementação de um intrincado conjunto de iniciativas e práticas, que, no seu conjunto, constitui o investimento da sociedade brasileira em recursos humanos e materiais com vistas a educação das próximas gerações. É um conjunto engloba legislação, programas de governo, projetos temáticos, gastos, gestão e avaliação e resultou em uma evolução recente com quatro caracteristicas principais: i) a rápida expansão das matrículas nas últimas décadas, em um contexto de transição populacional; ii) a descentralização de alguns aspectos de sua governância, com autonomia relativa de municípios, escolas e professores; iii) a consolidação de sistemas de avaliação externa em larga escala e iv) a manutenção de elevadas desigualdades sociais nas oportunidades de aprendizagem oferecidas dos alunos.

A desigualdade de oportunidades de aprendizagem é inerente estrutura do sistema educacional brasileiro (PATTO, 1991; COSTA RIBEIRO, 1991; PLANK, 1996; MELLO, 1995), com a consequente desigualdade de resultados (ALVES \& SOARES, 2007; RIBEIRO, 2011; SOARES ET AL., 2012) e é um dos pontos de partida desta pesquisa. Os componentes estruturais de desigualdade no sistema educacional brasileiro podem ser percebidos, de maneira concreta, nas diferenças de atribuições legais, na forma e na capacidade de aplicar e auditar recursos entre as três esferas administrativas do Estado brasileiro: federal, estadual e municipal (além da esfera privada) e captam grande interesse dos pesquisadores da área de políticas educacionais. A dinâmica que marca o sistema educacional brasileiro, 
com os investimentos educacionais distribuídos de maneira heterogênea em modalidade e intensidade, produz resultados diferentes entre regiões geográficas, estados e municípios, seja entre escolas da mesma localidade e dependência administrativa, seja entre alunos de perfil socioeconômico similar. Assim, aguçase a curiosidade do investigador em identificar possíveis padrões relacionados com a evolução do binômio qualidade - equidade. A identificação desses padrões é de interesse para o desenho, implementação e monitoramento de políticas públicas, pois seus componentes poderiam contribuir com ou emperrar sua eficácia e eficiência.

A história do atendimento educacional brasileiro tem ainda mais uma característica: a rápida e recente expansão das matrículas, que possibilitou a massificação da educação primária e secundária, deu-se com um lapso de décadas (OLIVEIRA \& ARAÚJO, 2005) em relação aos países com os quais o Brasil pretende, do ponto de vista da diplomacia, e, dada a sua importância econômica e geográfica, dividir a liderança política mundial, além de tornar-se atraente para investidores transnacionais.

A busca por ocupar espaço de destaque em nível global (VIGEVANI, OLIVEIRA \& CINTRA, 2003; VIGEVANI \& CEPALUNI, 2007) e por vantagens competitivas comerciais, e o fato de ser signatário de tratados e acordos internacionais cujos termos vinculam decisões internas (UNESCO, 2000; 2000), obrigam o país a emprender maiores esforços para alcançar um alinhamento de soberanias em certos fóruns de decisão e a modelar um perfil atrativo nos mercados de capital, e também resulta em maior exposição das características tanto positivas quanto negativas de sua identidade ${ }^{1}$. Uma das consequências desse aumento de esforço externo é a intensificação dos esforços internos para mitigar problemas sociais, econômicos, ambientais e de direitos humanos. Começa a

1 Um exemplo de como um país pode ter uma exposição positiva ou negativa em nível mundial é a Revista The Economist, que circula entre as lideranças políticas e empresariais do mundo todo. Recentemente, fez duas reportagens detalhadas sobre o Brasil: a da edição de novembro de 2009 tem o título "Brazil Takes Off" ou "O Brazil Decola" com uma imagem editada do Cristo Redentor transformado em foguete decolando na plataforma de lançamento, e a segunda, com uma abordagem oposta a essa, em setembro de 2013 traz o título "Has Brazil Blown It?", ou "O Brasil Estragou Tudo?", tem como capa a mesma edição da imagem do Cristo Redentor como foguete, mas com a decolagem abortada. Pode-se questionar o conteúdo da publicação, mas não sua influência em nível global. Relatórios internacionais como os do Pisa/Education at a Glance e os da Unesco/Educação para todos também expõem as fragilidades do país no setor da educação. 
haver um maior alinhamento das aspirações de justiça social com as de desenvolvimento econômico. Com isso, o interesse pelos resultados educacionais e a disponibilidade de recursos públicos e privados para o setor vêm aumentando, aparentemente fazendo parte de um novo contexto da sociedade brasileira.

Este trabalho busca organizar grande quantidade de informações disponíveis em diferentes órgãos de governo, com o objetivo principal de descrever, com base nas características da escolarização do contexto brasileiro já apontadas - expansão tardia das matrículas, descentralização e autonomia, avaliação externa e desigualdade de oportunidades de aprendizado - a evolução recente da educação no Brasil, com ênfase no estado da Federação com maior grau de industrialização e maior produção de riqueza, cujas dimensões territoriais e populacionais deixam para trás boa parte das nações do mundo: São Paulo.

A escolha do Estado deveu-se também a alguns de seus aspectos únicos no contexto educacional brasileiro. Em primeiro lugar, apresenta o maior contingente de pessoas em idade de escolarização obrigatória (de 4 a 17 anos): 8,1 milhões ou $18 \%$ do total brasileiro ${ }^{2}$ e número expressivo de municípios $\left(645\right.$, ou $12 \%$ deles $\left.^{3}\right)$. Em segundo, apresenta um rico histórico de municipalização, com modelos de implementação e etapas diferentes, que permitem o compartilhamento de matrículas de dependência administrativa distintas no mesmo município, ou em municípios de características semelhantes. Por último, conta com documentação, de maneira geral, farta e de fácil acesso em órgãos locais como a Fundação Seade e a Secretaria de Educação do Estado, além dos órgãos federais como o Instituto Brasileiro de Geografia e Estatística (IBGE), Ministério da Educação, Instituto de Pesquisa Econômica Aplicada (IPEA), e Fundo Nacional de Desenvolvimento da Educação (FNDE) - Siope (Sistema de Informações sobre Orçamentos Públicos em Educação).

A hipótese adjacente à escolha de São Paulo como foco da pesquisa relaciona-se ao fato de ser o estado (excetuando-se o Distrito Federal) que conta 
com a maior renda per capita do país $\left(\mathrm{R} \$ 30.243,00^{4}\right)$, o que poderia levar à suposição de existência de condições materiais favoráveis para a constituição de redes escolares mais estáveis e competentes. Nesse sentido, a principal contribuição deste trabalho seria a sistematização de dados de maneira a gerar informações com as quais se possa perceber se o processo de descentralização das matrículas do ensino fundamental do estado para seus municípios se deu de forma a contribuir ou não para o binômio qualidade-equidade, em que tipo de contexto local e com que perspectivas futuras.

Fez-se, primeiramente, um levantamento bibliográfico dos conceitos teóricos relacionados ao tema, o que permitiu identificar, entre outras, dois polos antagônicos no largo espectro de argumentações sobre a política de descentralização do controle e operação dos serviços públicos de educação do nível estadual para o municipal no estado de São Paulo.

Em um deles localizava-se a tese da gestão estadual, que percebia a descentralização como positiva com base na hipótese de uma diminuição da complexidade na gestão e do aumento do controle social por parte dos beneficiários da política. No outro, encontrava-se a maior oposição do ponto de vista político, a do sindicato dos docentes do Estado, que previa um aumento das desigualdades educacionais em São Paulo, dadas as grandes diferenças de capacidade de investimento e de gestão nos seus municípios.

Outra importante vertente de argumentos contra a transferência de matrículas do estado para seus municípios era em relação à fragilidade de recursos humanos e materias em nível local, que poderia colocar em risco a expansão de todas as etapas da educação básica, assim como a evolução futura de sua qualidade, além de dar oportunidade para outro tipo de transferência de responsabilidade, que inclui o setor privado.

Ainda na bibliografia, foi feito um mapeamento da produção recente sobre descentralização de matrículas no Estado, com ênfase na modalidade de trabalhos do tipo relato de contexto. Essas produções, do tipo dissertação ou tese, em geral 
de profissionais ligados às administrações municipais de educação, como gestores, funcionários e professores, trouxeram muitos detalhes sobre a forma de implementação do processo de transferência de matrículas da Secretaria Estadual para as prefeituras, ou da criação/expansão de redes locais. Com a leitura desse material definiu-se como principal variável de análise da primeira parte da pesquisa o percentual de matrículas sob controle local em cada município, uma vez que se constatou ritmos muito diferentes nos processos de descentralização das matrículas, mesmo quando os municípios têm sua educação reconhecida como "municipalizada".

Com a diversidade de contextos de implementação mais profundamente compreendida, partiu-se para organizar dados disponíveis de forma a contextualizar a implementação da política no estado de São Paulo, a partir de uma visão geral da evolução mais recente do setor educacional em âmbito nacional.

Os dados do Censo decenal do IBGE mais recente disponível, de 2010, permitiram identificar tipos de município sob diferentes aspectos, por tentativa e erro. A referência inicial foi o alerta apontado por Celina Souza (2004), que defendeu a importância de se fazer uma diferenciação entre os municípios, tanto para pautar a distribuição de recursos por outros níveis de governo, quanto para fazer parte do desenho de programas ou políticas que possam ser impactados por questões ligadas à diversidade local.

\begin{abstract}
Apesar de no Brasil a definição oficial de município não fazer distinção entre a enorme diversidade dos 5.561 municípios, nem mesmo em relação ao grau de urbanização e à separação entre áreas urbanas e rurais, assim como entre a sede e os distritos municipais, existem diferenças marcantes entre eles. Assim, a definição oficial de município torna-se uma ferramenta meramente administrativa, que independe da incorporação de variáveis importantes, principalmente o tamanho da localidade. Tal uniformidade também significa que as regras aplicadas aos governos locais são invariáveis e independem da complexidade das tarefas a eles atribuídas. (SOUZA, 2004, pg. 28)
\end{abstract}

Foram então escolhidas quatro variáveis independentes que poderiam influenciar a variável dependente "estágio de municipalização" (a proporção entre matrículas municipais e estaduais em cada cidade): tamanho da população, 
produção de renda em nível municipal (PIB percapita), nível de renda da população e localização no sistema de divisão administrativa do estado, que permitiram a identificação de quatro grupos distintos de municípios, a saber: os que municipalizaram todo o ensino fundamental, os que praticamente não municipalizaram, os que pertenciam à unica região administrativa do estado que, em conjunto, tinha concluído o processo de municipalização nos anos iniciais do ensino fundamental até 2012 e os que tinham serviços educacionais com performance alta em todas as edições da Prova Brasil.

Ao se analisar a distribuição das matrículas pelas diferentes esferas administrativas ao longo do tempo, percebeu-se padrões diferentes de crescimento da rede privada em nível local, que não estavam exclusivamente relacionados ao nível de renda familiar do município, assim a variável percentual de matrículas na rede particular foi incluída na análise.

Na segunda parte, onde o objetivo era comparar a evolução da qualidade dos serviços educacionais entre os grupos de municípios selecionados, utilizou-se a evolução da média de proficiência das escolas municipais em Língua Portuguesa em cada uma das quatro edições da Prova Brasil. Esse indicador, para os anos iniciais do ensino fundamental, apresentou trajetória mais regular no grupo com municipalização completa nas duas etapas. Da mesma forma que, com base na evolução da distribuição das matrículas em cada município, constatou-se que o crescimento da rede particular para aquele grupo é menor que no restante do estado.

A contribuição específica desta pesquisa se constitui na tentativa de, por meio da categorização dos municípios sob os critérios descritos, identificar contextos locais que, sistematicamente, facilitem ou dificultem a provisão de serviços públicos de educação de qualidade e com equidade, a partir de uma política de descentralização das matrículas. Embora, para os anos finais do ensino fundamental, a progressão dos resultados de proficiência em Língua Portuguesa ainda seja errática tanto para as redes municipais quanto para a estadual, em relação aos anos iniciais, os municípios do estado de São Paulo que implantaram a política de forma mais abrangente apresentaram resultados mais consistentes do que os que não a implementaram. 


\section{Objetivos, hipóteses e metodologia da pesquisa}

O principal objetivo deste trabalho foi identificar condições locais ou perfis sistemáticos de municípios que revelassem a materialização do binômio qualidade-equidade na educação pública do estado de São Paulo, pela perspectiva comparativa de um aspecto crucial de gestão: o controle centralizado (no nível do estado) versus o controle descentralizado (no nível do município) da operação dos serviços. Foi dada atenção para alterações na distribuição das matrículas entre as esferas administrativas presentes no estado (estadual, municipal e privada) nos anos mais recentes e a sua relação com algumas características dos municípios quando comparadas, principalmente, com resultados e informações obtidas via avaliações externas e levantamentos de dados escolares oficiais.

O recorte temporal escolhido para essa análise foi, a partir de uma primeira "foto" o mais próxima possível da promulgação da Constituição Federal de 1988 (quando a base legal de descentralização de políticas sociais foi instituída) seguir com um "filme", com início em 1996 até os dados mais recentes disponíveis. Nesse ano foi instituida a Lei de Diretrizes e Bases da Educação (LDB 9394/1996), que detalhou o escopo e as atribuições da educação básica brasileira, e em 1998 teve início a implementação do Fundo de Manutenção e Desenvolvimento do Ensino Fundamental e de Valorização do Magistério (Fundef 9424/1996, substituído pelo Fundeb 6253/2007) que alteraram estrutura contábil e legal de financiamento educacional público. Assim, pode-se apresentar um panorama amplo do andamento da política de descentralização de matrículas no Estado de São Paulo.

As unidades de análise foram os municipíos do Estado, procurando-se neles identificar características (tamanho da população, produção de riqueza e renda em nível local, estágio de municipalização das matrículas de ensino fundamental e localização em regiões de governo) que possam estar associadas à estruturação de redes de ensino que ofereçam maior qualidade e equidade aos estudantes do 
ensino fundamental, medidas pela distribuição do desempenho médio das escolas por esfera administrativa (estadual ou municipal). Os critérios de escolha desses parâmetros estão detalhados em capítulo específico.

As principais perguntas de pesquisa são:

1) Como se deu a distribuição das matrículas no Estado de São Paulo:

a) Em uma perspectiva temporal, desde a Constituição Federal de 1988, principalmente após a implementação da Lei de Diretrizes e Bases e do Fundo de Manutenção e Desenvolvimento do Ensino Fundamental e de Valorização do Magistério de 1996, até os dados mais recentes disponíveis?

b) Em uma perspectiva comparativa, há alguma característica sistemática dos municípios que diferencie o ritmo de municipalização ou de evolução de seus resultados?

2) Qual a esfera administrativa ou perfil de rede que vem conseguindo prestar melhor atendimento educacional à população, medido, inicialmente, pela evolução do Ideb, mas detalhado, em termos de equidade, pela evolução da distribuição, no nível de município e por escola das médias de Língua Portuguesa nas quatro edições da Prova Brasil?

As perguntas foram elaboradas a partir dos seguintes pontos de partida, que constituíam os polos antagônicos de argumentação a respeito dessa política pública, antes de sua implementação:

1) No Estado de São Paulo, os municípios, em média, apresentariam melhores resultados de qualidade e equidade que a rede estadual, pelas questões de menor complexidade de sua gestão (argumento usado pela Secretaria Estadual de Educação para iniciar o massivo processo de municipalização em 1995) e de crença na descentralização como indutor da qualidade no serviço público por meio do controle social;

2) Municípios com maior geração de renda local e, portanto, maior disponibilidade de recursos públicos vinculados à educação, além do mínimo repassado pelo Fundef/b, ou com população com maior renda teriam maior probabilidade de oferecer educação de qualidade à população, aumentando as desigualdades 
educacionais no estado (hipótese usada pela Direção da APEOESP - sindicato estadual dos professores - para se opor à municipalização) ${ }^{5}$

A metodologia para selecionar e analisar as informações disponíveis referentes a população, matrículas, produção de renda e nível de renda da populaçao e divisão administrativa do estado, além dos dados de desempenho nas provas nacionais padronizadas e indicadores de qualidade, é apresentada a seguir, de acordo com sua relação com cada pergunta de pesquisa:

1) Pergunta 1:

a) Apresentação do histórico da evolução das faixas etárias relacionadas com a educação básica dadas pelos Censos e projeções demográficas do IBGE e Fundação Seade e do histórico da distribuição das matrículas de cada uma das etapas da educação básica desde o período mais próximo possível de 1988 até o mais recente disponível, disponibilizadas pelo INEP e Fundação Seade;

b) A partir da situação mais recente da distribuição de matrículas, estabelecer categorias de nível de municipalização para os anos iniciais e finais do ensino fundamental e sua relação com tamanho de município, nível de produção de renda local (PIB percapita), percentual de domicílios por faixa de renda e localização nas áreas de governo do estado. Neste ponto os dados foram agrupados formando indicadores de análise calculados por mim, como as faixas de PIB percapita, de proporção de domicílios com renda acima de dois salários mínimos ou de proporção de matrículas em rede privada.

2) Pergunta 2:

a) Apresentação da evolução comparativa do desempenho da rede estadual e das redes municipais dada pela evolução do Ideb, das médias de proficiência em Língua Portuguesa e pelo valor mais recente do indicador distorção idade-série;

b) Identificação de quatro perfis sistemáticos de municípios: i) os que implementaram a política de municipalização para todo o ensino fundamental, ou

5 GHANEN et al. 1991, pg: 64 
seja, com controle de $100 \%$ das matrículas nas duas etapas; ii) os que a implementaram de forma frágil, ou com menos de $25 \%$ de matrículas sob controle local; iii) a Região Administrativa de Barretos, que apesar de concentrar municípios com perfil de renda mais baixa, conta com a totalidade de seus municípios com matrículas locais nos anos iniciais e já avançando para os anos finais, e iv) os que em todas as edições da Prova Brasil tiveram desempenho alto, como referência para comparar a evolução das médias de proficiência em Língua Portuguesa, além dos indicadores educacionais mencionados.

3) O esforço de sistematização de dados evidenciou uma lacuna deixada pelo Ideb em sua função de comparar contextos municipais. Este trabalho traz, então, um esboço de indicador complementar para esse fim, com a seguinte composição:

\begin{tabular}{lr} 
Cálculo indicador - anos iniciais & $\begin{array}{l}\text { Acréscimo de } \\
\text { pontos }\end{array}$ \\
\hline Taxa de municipalização na etapa & $0-100$ \\
\hline Taxa de frequência na faixa etária correspondente & $0-100$ \\
\hline $\begin{array}{l}\text { Taxa de distorção idade-série na etapa } \\
\text { correspondente }\end{array}$ & $0-100$ \\
\hline Município no nível 1ou 2 de renda domiciliar & +100 pontos \\
\hline Município de população nível 5, 6 ou 7 & +100 pontos \\
\hline Sub-total características do município & $\mathbf{5 0 0}$ \\
\hline Média de proficiência adequada para a etapa & de 200 a 250 \\
\hline Valor máximo possível & $\mathbf{7 5 0}$ \\
\hline
\end{tabular}

$\mathrm{Na}$ fase final deste trabalho, o perfil de expansão da rede privada em nível local foi incluído na análise, com base na seguinte lógica: se existem matrículas gratuitas disponíveis para todos os alunos e $21 \%$ deles estão na rede privada, em um estado onde $93 \%$ da população conta com renda mensal abaixo de 5 Salários Mínimos (valor de $2010=\mathrm{R} \$ 510,00$ ), algo além da renda pode estar fazendo as famílias pagarem um prêmio para sair da escola pública. A hipótese levantada que justifica a inclusão da variável é de que a escolha das famílias se relaciona com uma percepção de vantagem de qualidade para a opção tomada. 


\section{Referencial teórico sobre descentralização na educação}

A descentralização da educação pública não é um tema novo. Mesmo no caso do Brasil, onde, de forma particular, a descentralização na educação tem sido caracterizada simplesmente como a transferência, com ampla autonomia administrativa, do controle gerencial, operacional e político das matrículas e da oferta das atividades de ensino pelos estados da federação a seus municípios no recente período pós regime militar. Vários campos do conhecimento há anos esmiúçam o assunto e cada um deles costuma ter um foco específico, típico de sua área de interesse, apesar de, mais recentemente, as produções começarem a ter componentes multidisciplinares e com metodologias mistas. No entanto, uma pergunta permanece atual: "qual é a capacidade desse mecanismo em contribuir para o binômio qualidade-equidade?”. A profusão de dados oriundos principalmente das avaliações em larga escala e dos censos escolares é um campo fértil para o detalhamento e aprofundamento da indagação. $\mathrm{O}$ recente trabalho de Soares \& Alves (2013) mostrando o efeito local das escolas no contexto de seus municípios é um exemplo dessa nova fase de pesquisa. Os projetos de pesquisa do Centro de Estudos da Metrópole ${ }^{6}$, "Políticas Públicas e Desigualdade Territorial" e "Política e Políticas redistributivas", que produziram recentemente um indicador com 10 dimensões das condições de saúde e de educação dos municípios brasileiros (ARRETCHE, FUSARO \& GOMES, 2012) mostram um investimento acadêmico susbtancial na compreensão do tema das relações entre níveis de poder e a evolução das políticas públicas de bem-estar para os cidadãos.

No âmbito da educação, tanto a discussão teórica, quanto os relatos históricos e boa parte das pesquisas sobre os resultados da municipalização concentram-se mais na transferência de matrículas do que hoje se chama ensino

6 http://www.fflch.usp.br/centrodametropole/1102 
fundamental e menos nas implicações de modelos de federalismo ou nos contextos locais que facilitem ou dificultem o desenvolvimento social a partir dos municípios. As áreas de Ciências Políticas e Econômicas costumam estudar, geralmente em uma abordagem nacional, desenhos institucionais e políticos, seus conceitos e implicações. Entretanto, o interesse na relação dessas estruturas de estado com a superação dos grandes desafios sociais e econômicos do país e, a partir de 1984, em um ambiente político democrático, é crescente nas diferentes áreas do conhecimento e, de certa forma, convergente para avaliar seus resultados e identificar detalhes de contexto local.

Como forma de ilustrar a variedade de contribuições da pesquisa brasileira para a compreensão dessa relação, apesar das diferenças de enfoque teórico e metodológico, apresento a seguir três exemplos de abordagem entre os diferentes campos de estudo (Ciências Políticas, Educação e Políticas Públicas)

No campo das Ciências Políticas, Tavares de Almeida, em "The new local agenda: elite support for decentralization of social services in brazil" (2000) argumenta que as aspirações democráticas pós-ditadura eram a principal motivação para tornar os serviços públicos mais "locais" ${ }^{7}$ no período da democratização:

A descentralização foi um tema de maior relevância na agenda da redemocratização no Brasil nos anos 1980. O regime autoritário e burocrático (1964-1984) promoveu a concentração das decisões, dos recursos financeiros e da competência administrativa no nível federal. O país tornou-se um exemplo extremo de federalismo centralizado, quase indistinguível de um modelo político unitário. Foi natural até demais que a oposição ao regime militar tivesse tomado a descentralização

\footnotetext{
7 Decentralization was a major issue of the democratization's agenda in Brazil, during the 80s. Bureaucratic-authoritarian regime (19641984) promoted concentration of decisions, financial resources and administrative capacities at federal level. The country became an extreme case of centralized federalism, almost undistinguishable from a unitary polity. It was only too natural that democratic opposition to military rule took decentralization as one of its most cherished motto, together with social justice, rule of law and citizen's participation. Especially in the social policies' domain, decentralization to local level was argued for in the name of democracy as much as in the name of efficiency and efficacy. It would allow not only for citizen's influence in decision-making but also for citizen's control over social services provision reducing widespread red tape, clientelism and corruption, which made social policies inefficient and frequently regressive.
} 
como o seu motto preferido, junto com justiça social, estado de direito e participação cidadã. Particularmente no domínio das políticas sociais, a descentralização para o nível local era defendida tanto em nome da democracia quanto em nome da eficiência e da eficácia. Ele permitiria não só que os cidadãos execessem influência no processo decisório, mas que controlassem a provisão de serviços sociais, reduzindo a burocracia, o clientelismo e a corrupção que tinham tornado as políticas sociais ineficientes e, frequentemente, regressivas. (ALMEIDA \& CARNEIRO, 2000, pg.2 - tradução nossa)

$\mathrm{Na}$ área da Educação, a contribuição desse afã democrático na melhoria da cobertura, qualidade e equidade dos serviços públicos do setor foi vista com mais cautela, uma vez que a sua materialização é complexa e onerosa, demandando muito mais que a mobilização por igualdade de direitos. Neste campo, cito Azanha que em "Uma idéia sobre a municipalização do ensino" (1991) faz a ponte entre democracia e descentralização, lembrando que a aspiração por descentralização talvez tenha pouca relação com o aprimoramento da educação:

Em primeiro lugar, é preciso lembrar que, após A. Teixeira ${ }^{8}$, o tema da municipalização saiu de moda por muitos anos e não são poucos aqueles que interpretam o seu retorno aos debates educacionais como expressão da vontade política de fragmentação dos movimentos sindicais do magistério. Embora essa interpretação possa ter seu grão de verdade, é inegável que o tema da municipalização do ensino é também um componente de um pathos participativo. Após duas décadas de uma ordenação legal autoritária da vida nacional, há uma ânsia participativa em torno da qual têm se congregado todas as camadas da população. Hoje, há até um mito da participação como se apenas as iniciativas que dela decorressem fossem válidas e aceitáveis, até mesmo quando a complexidade do assunto pudesse não recomendar simples decisões consensuais, frutos de esforços participativos. Como integrante desse pathos, o termo municipalização se relaciona fortemente com outros como descentralização, desconcentração,

$8 \mathrm{O}$ autor se refere ao artigo TEIXEIRA, Anísio. A municipalização do ensino primário. Revista Brasileira de Estudos Pedagógicos. Rio de Janeiro, v.27, n.66, abr./jun. 1957. p.22-43., no qual o autor comenta os dispositivos constitucionais que estabelecem as responsabilidades e níveis mínimos de aplicação de recursos de cada ente federado no que diz respeito a educação pública e sugere a) a criação de fundos de educação administrados por Conselhos de Educação para gerir e fiscalizar o uso de recursos; b) uma proposta para sua alocação, com base na noção de que "o fundo pertence às crianças e aos educandos dos municípios, dos estados, do Brasil e sòmente pode ser dispendido de modo a assegurar aos seus legítimos beneficiários as vantagens que lhes deva virtualmente garantir", por exemplo, sugerindo uma proporção de "60\% do total do custo da classe ao pessoal (sendo dos $60 \%$, $80 \%$ para o professor e $20 \%$ para administração e demais auxiliares), $30 \%$ para material e $10 \%$ para o prédio, a ser construído, mediante empréstimo amortizável por essa percentagem fixa da despesa", c) que a União poderia complementar os recursos de estados e municípios com não menos de $30 \%$ de seus recursos para educação; demonstra a necessidade de aumento de recursos para o setor, confrontando dados sobre a cobertura existente e a necessária e d) mostra que a importância de se acompanhar o efetivo gasto por aluno como forma de avaliar o esforço de cada ente federado. 
consenso, etc., todos eles positivamente valorizados, como se invariavelmente indicassem maior democratização e, também, maior racionalização. Todos sabemos que as coisas não são bem assim e que a simples administração local do ensino não representa por si só nenhuma garantia de sua efetiva democratização e pode até mesmo ser oportunidade de exercício de formas mais duras de coerção sobre o processo educativo e sobre o magistério." (AZANHA, 1991, pgs. 6263) [grifos meus]

Na área de Políticas Públicas, o trabalho de Celina Souza, “ Reinventando o poder local: limites e possibilidades do federalismo e da descentralização" (1996) traz contribuições particularmente interessantes porque estuda justamente a relação do federalismo com o desenho de políticas públicas e a análise das condições locais pré-existentes. A autora apresentou uma visão realista dos condicionantes da descentralização, argumentando que, ao contrário dos que atribuíam os esforços de desconcentração de poder a uma aspiração democrática, seu principal motor poderia ser antagônico à melhoria da qualidade dos serviços públicos, embora representasse grande utilidade política:

Apesar dos compromissos assumidos no Brasil a favor de valores voltados para a democracia política e social e onde a descentralização se inscreve, inúmeros constrangimentos têm dificultado $\mathrm{o}$ alcance dos objetivos constitucionais e o equacionamento dos vários problemas que a Constituição procurou enfrentar. (SOUZA, 1996, pg. 103) [...]

Argumenta-se neste artigo que a razão de ser do federalismo brasileiro sempre foi, e continua sendo, uma forma de acomodação de demandas de elites com objetivos conflitantes, bem como um meio para amortecer as enormes disparidades regionais.

No que se refere à descentralização, apesar de políticas decentralizadas estarem em voga na maioria dos países, o conceito de descentralização é vago e ambíguo. A popularidade da descentralização respalda-se em vários fatores, como por exemplo, nos ataques da direita e da esquerda no poder excessivo dos governos centrais e na capacidade que o conceito traz embutida de prometer mais que se pode cumprir. (idem, pg. 104) [grifos meus]

Para qualquer que fosse o desenho de Estado que tivesse sido estabelecido no país, não temos ainda nem três décadas de regime democrático com a nova Constituição Federal, que reconheceu e ampliou uma ampla gama de direitos individuais e coletivos. Portanto, não seria razoável esperar que todos os direitos 
humanos, sociais e culturais já estivessem plenamente atendidos, varrendo do cenário nacional não só a hierarquia de poder determinante das graves e históricas injustiças sociais, como elas próprias, tendo sido cultivadas durante vários séculos. Mesmo assim, há uma insatisfação e angústia latentes quanto a capacidade de o país aproximar-se do padrão de vida, de justiça social e de direitos humanos de nações mais desenvolvidas. Um exemplo concreto e recente de expectativas latentes na população quanto a melhoria de padrão de atendimento social, dentre eles a educação, seria o mote "Educação padrão FIFA" ${ }^{9}$, que surgiu nas massivas manifestações de rua de junho de 2013 e que resume uma aspiração coletiva, mesmo que não expresse de forma objetiva o que significa um "padrão FIFA" transposto para o ensino, nem, pelo menos até o momento, enseje um movimento político organizado pela qualidade e equidade na educação, como se tem visto, por exemplo, no Chile nos últimos anos. Até aqui, pode-se dizer que há uma aspiração por algo diferente, mas não uma mobilização clara, seja popular ou da classe média, em torno de uma agenda definida ${ }^{10}$. Mesmo a tramitação e as negociações do novo Plano Nacional de Educação ficam restritas a alguns grupos de interesse do setor, como, por exemplo, a representação sindical docente, as famílias de alunos com necessidades educacionais especiais e empresários da educação, cada qual no seu embate com o governo federal.

Decisões estruturais cruciais já foram tomadas pela Assembléia Nacional Constituinte de 1987/8 sobre a configuração das matrículas da educação infantil e fundamental, tendo sido consolidadas por legislação complementar e por iniciativas governamentais em todos os níveis. Aparentemente, a pressão atual por mudanças em fóruns especializados tem foco na efetivação de um sistema nacional de educação, que materialize a ideia de Regime de Colaboração e no aumento de recursos a quem foram atribuídas responsabilidades, mas não na

9 A Fédération Internationale de Football Association (FIFA) é uma associação regida pela legislação suíça, fundada em 1904 e sediada em Zurique. É composta por 208 federações nacionais e tem como objetivo, de acordo com os seus Estatutos, a melhora contínua do futebol. Em http://pt.fifa.com/aboutfifa/organisation/index.html. Acesso em 15/01/2014.

10 Ver: Compendio de Demandas y Propuestas Estudiantiles Coordinadora Nacional de Estudiantes Secundarios CONES. Documento preparado pelo Movimento Estudantil de Estudantes Secundário do Chile, com um diagnóstico detalhado do problema da educação no país e com uma pauta de reivindicações clara e estruturada, que alterou o rumo da política nacional chilena nas eleições recentes. Em: http://www.elciudadano.cl/wpcontent/uploads/2012/08/propuesta-cones.pdf. Acesso em 20/01/2014. 
reversão delas para os governos estaduais ou central ${ }^{11}$. Assim, talvez o que ainda esteja faltando desde a redemocratização e da sua nova Constituição seja definir o que se quer alcançar de forma mais clara, verificar se a estrutura existente é apropriada para o que se almeja, avaliando o potencial de contribuição de cada ente federado para atingir os objetivos traçados, identificando também necessidades de ajustes e a forma de fazê-los.

De fato, no mesmo artigo de 1991, Azanha conclui:

Municipalização do ensino é apenas uma expressão abstrata e, nessas condições, nada indica que deva provocar reações de apoio ou de desaprovação. É preciso, como fez Anísio Teixeira, que indiquemos claramente quais são os problemas que se pretende resolver com uma política municipalista em educação. Sem isso, a retórica pró-municipalização, como também a retórica antimunicipalização são inteiramente vazias, não obstante o tecnicismo de que se revistam e, eventualmente, podem até ensejar fortes prejuízos à causa educacional. Contudo, foi nesse quadro que as constituições federal e estadual (sic) instituíram a municipalização do ensino. (AZANHA, 1991, pg.63)

Alguns trabalhos mais recentes (D'ATRI, 2007; LEME, PAREDES \& SOUZA, 2009; CANO, 2010; CENEVIVA, 2011; LEME et al., 2012; SOARES \& ALVES, 2013) procuram levantar evidências sobre a contribuição da descentralização das matrículas e seus desdobramentos para o binômio qualidadeequidade. Tais trabalhos, marcadamente de cunho quantitativo, mostram, em geral, que as evidências empíricas disponíveis não sustentam que a "ânsia participativa" ou a transferência pura e simples de matrículas sejam preponderantes para a universalização do ensino obrigatório ou para sua materialização com qualidade e equidade. Permanece o desafio de compreender a relevância da divisão de responsabilidades, poderes e atribuições entre os entes federados para o desenho das políticas públicas do setor, mais recentemente com foco em seus resultados e em detalhes de sua implementação.

11 O Sen. Cristovam Buarque apresentou substitutivo ao PNE com uma proposta de federalização que não tem sido levada em conta no debate da votação do PNE no Senado: http://www12.senado.gov.br/noticias/materias/2013/12/11/cristovam-buarque-defende-aprovacao-de-seu-substitutivo-ao-pne 
A análise do debate sobre o tema na área da Educação neste trabalho seguirá a rota traçada por Araújo (2005), que fez uma detalhada revisão bibliográfica e dividiu em três vertentes os vários pontos de vista expostos pela produção acadêmica brasileira sobre o tema "intensificada nos anos 1980/90", mas que "preservou a polarização do debate das décadas de 1950 e 1960" com argumentos que "enfatizavam a necessidade de uma descentralização municipalista" ou que demonstravam a "inviabilidade dessa descentralização": a) os partipacionistas, b) os que enfocam a análise na viabilidade técnica e nas condições prévias existentes e c) os que denunciam a municipalização por meio de suas consequências político-ideológicas e econômicas (pg.50).

Sem negligenciar as conceituações e definições das áreas de Ciências Políticas e Econômicas, que explicam como e porquê nosso país chegou ao desenho de federalismo constitucional, institucional e político atual, este levantamento teórico teve como foco identificar referências que estabelecessem possíveis ligações conceituais entre as vertentes do debate identificadas por Araújo, mais frequentemente argumentadas na área de educação, e "a democratização, eficiência e eficácia" (ALMEIDA, 2000) dos serviços de educação pública em uma perspectiva de implementação. Portanto, o tipo de trabalho priorizado aqui foi o dos que se debruçam sobre contextos específicos de municipalização ou de relatos de sua implementação. A vasta produção sobre temas relacionados a "participacionismo" e controle social (ou participação comunitária) (MARTINS, 2009) e as de maior enfoque político ou sindical (REIS, 2006) debruçam-se pouco sobre os condicionantes locais de implementação, foco deste trabalho.

Muito brevemente, em relação ao "participacionismo" ou à capacidade de controle social pelas comunidades e populações locais para demandar, contribuir na implementação e monitorar serviços públicos no sentido do desenvolvimento social (e do econômico), parece mesmo haver uma certa romantização de seu 
potencial, como apontou Proud'Homme $(1995)^{12}$, a partir de uma aspiração democrática e igualitária, sendo a obra de Tocqueville a mais clássica referência sobre o tema. De fato, o contexto ${ }^{13}$ em que o autor escreveu sua famosa "A Democracia na América - Livro 1: leis e costumes", publicado em sua primeira versão em 1835, é o de contrapor o regime absolutista e feudal vencido pela Revolução Francesa e a nascente nação igualitária e democrática que eram os Estados Unidos da América na época de sua histórica viagem de investigação em 1831/2. Ou seja, um espírito de renovação que pode-se dizer análogo ao do brasileiro pós-ditadura:

Entre os novos objetos que me chamaram a atenção durante minha permanência nos Estados Unidos, nenhum me impressionou mais do que a igualdade das condições. Descobri sem custo a influência prodigiosa que exerce esse primeiro fato sobre o andamento da sociedade; ele proporciona ao espírito público certa direção, certo aspecto às leis; aos govemantes, novas máximas e hábitos particulares aos governados. Não tardei a reconhecer que esse mesmo fato estende sua influência muito além dos costumes políticos e das leis, e tem império sobre a sociedade tanto quanto sobre o governo: cria opiniões, faz nascer sentimentos, sugere usos e modifica tudo o que ele não produz. (Tocqueville, 1927, pg. 7) [ grifos meus]

$[\ldots]$

12 Prud'homme (1995) sobre os perigos da descentralização (em uma abordagem econômica): "the model assumes that the taxpayers/voters of each jurisdiction will express their preferences in their votes. This hypothesis bears little relationship to local electoral behavior in developing countries. Local elections, when they exist, are usually decided on the basis of personal, tribal, or political party loyalties. People vote for a mayor they know, a member of their group, or a party they like. This is true in all countries; local elections are often a mere rehearsal of national elections and say little about local preferences. In addition, the platforms on which local elections are fought (when they exist) are often vague and unrealistic. The menus offered for choice are unlikely to express the electorate's preferences." (grifo meu)

$13 \mathrm{Na}$ introdução da edição de 1927 François Furet apresenta o autor e a obra: "Tocqueville pertence ao mundo vencido pela Revolucao Francesa, da qual tira, como toda a sua geração, o sentimento da marcha irreversível da história. Mas, como é um espírito impelido para a abstracao, o famoso "destino" romantico assume nele a forma de um conceito tirado diretamente da experiencia do seu meio e que e a vitoria do principio democratico sobre o principio aristocratico. Toda a sua obra pode ser encarada como uma interminavel reflexao a respeito da nobreza (pg. XIV) ... Diversamente de Marx, por exemplo, para quem o sentido da historia e demonstravel, e o fim do capitalismo dedutivel das leis economicas que o governam, ele coloca como axioma ou como evidencia a ideia de que a humanidade caminha a passos largos para a era democratica (pg. XVI).

.. Outro elemento-chave da independencia da sociedade americana: o nivel elevado de cultura. Aqui Tocqueville se afasta de Montesquieu: a mola das republicas nao e a virtude, sao as luzes - ele entende por tal a democratizacao dos conhecimentos, notadamente em materia politica. Indagando- se a respeito das "mil razoes que fazem os Estados Uni dos suportarem a liberdade republicana", ele escreve nos seus cadernos de viagem: "Há uma razão maior que domina todas as outras e que, depois que todas elas foram expostas, prevalece por si só na balança. O povo americano considerado cm massa não só é o mais esclarecido do mundo mas - o que eu coloco bem acima dessa vantagem - é aquele cuja educação política prática é a mais avançada. É essa verdade, na qual acredito firmemente, que faz nascer em mim a única esperança que tenho para a felicidade futura da Europa (pgs. XXVI-XXVII). 
Mas se lhes parecer util voltar à atividade intelectual e moral do homem para as necessidades da vida material e empregá-la para produzir o bem-estar; se a razão lhes parecer mais proveitosa aos homens do que o gênio; se seu objetivo não for criar virtudes heróicas, mas hábitos serenos; se preferirem ver vícios a ver crimes, e ver menos grandes ações contanto que se produzam menos fracassos; se, em vez de agir no seio de uma sociedade brilhante, basta-lhes viver no meio de uma sociedade próspera; se, enfim, o objetivo principal de um govemo não for, na opinião de vocês, dar ao corpo inteiro da nação o máximo possível de força ou de glória, mas proporcionar a cada um dos individuos que o compõem o máximo de bem-estar e evitar-lhe ao máximo a miséria, entao igualem as condições e constituam o governo da democracia. (idem, pg. 286) [grifos meus]

O que chama atenção na obra de Tocqueville e que pode caracterizar uma significativa diferença do contexto brasileiro (atual ou histórico) é justamente a constatação que o autor fez in loco do compromisso moral dos membros das comunidades com a igualdade entre eles, o que influenciava as relações políticas, institucionais, jurídicas e comunitárias na América nascente. Para o autor, as observações que fez em suas viagens e que sistematizou em sua obra-relatório, eram um claro contraponto ao contexto de sua origem, marcado pelo individualismo e pelo espírito de corpo da aristocracia (França na primeira metade do séc. XIX), e foram apresentadas por ele como exemplo a seguir. Juntamente com influências humanistas e iluministas da época, a consolidação da igualdade e da liberdade como valores universais acabou se espalhando pela Europa, principalmente a partir do início século seguinte. Mas para nós brasileiros, acostumados a uma lógica de classes e de grupos sociais hierarquizados, a democracia e a igualdade parecem sedutoras no discurso, mas apenas de maneira incipente vão tomando forma no dia a dia.

De fato, com um salto no tempo da época de Tocqueville para os dias atuais e, restringindo a comparação ao campo educacional, o compromisso com o desempenho dos alunos e uma busca permanente da equidade educacional é concreto nos Estados Unidos, no Canadá e em muitos países da Europa, alcançando resultados educacionais e sociais melhores que os nossos, o que é recorrentemente exposto em relatórios de acompanhamento educacional internacionais, como Pisa (OCDE, 2001; 2004; 2007; 2010; 2012) e Educação para Todos (Unesco, 2002; 2014; Unesco-IES, 2012), mesmo que ainda se 
deparem com questões remanescentes (e permamentes) do binômio qualidadeequidade. A existência desse compromisso com a igualdade por parte da sociedade brasileira é colocada em cheque não só por Azanha e Souza, já citados, mas por Plank (1996) e, por obras icônicas como "Casa Grande e Senzala" (FREYRE, 1933) e "Raízes do Brasil" (HOLANDA \& CÂNDIDO, 1936) e mais recentemente, a "Cabeça do Brasileiro" (ALMEIDA, 2007).

Além disso, não é verdade que a educação de qualidade com equidade só possa ser conquistada em ambientes democráticos, ou com governos ditos progressistas, como evidenciam não só as avaliações internacionais, mas trabalhos de cunho comparativo transnacionais como os de Carnoy (2007), Levin (2001), Hargreaves \& Fullan (2009), Mourshed (2007) e Barber \& Mourshed (2010).

Em um deles, "Change Wars" (HARGREAVES \& FULLAN, 2009), Darling-Hammond (2009), apresenta quatro abordagens teóricas de hipóteses de mudança que norteiam reformas educacionais pelo mundo e que competem entre si: a burocrática, a profissional, a mercadológica e a democrática.

Sobre a hipótese democrática, ela aponta que seu fundamento é que a apropriação local da gestão das escolas públicas faz com que elas sejam conduzidas de forma mais próximas a quem elas atendem, mas argumenta ${ }^{14}$ que:

\begin{abstract}
. . . Assegurar que boas decisões são tomadas depende, mais uma vez, na disponibilidade de sólidos conhecimentos profissionais e forte compromisso moral dentro da escola, apontando para a importância crucial de combinar a agenda profissional com a de garantir processos decisórios democráticos. (DARLING-HAMMOND, 2009, pg. 55)
\end{abstract}

É difícil, então, não concordar com Azanha, no sentido que a descentralização das decisões sobre educação permanecerão vazias e sem efeito se não forem embasadas por uma agenda política e operacional claramente definida.

Partindo para a terceira vertende apontada por Araújo (a segunda será abordada em mais detalhe a seguir), que nos leva para os trabalhos de oposição

14 ". . . ensuring that good decisions are made depends, once again, on the availability of solid professional knowledge and strong moral commitments within the school, suggesting the critical importance of combining professional agenda with one to secure more democratic decision-making." 
política ao controle da educação pelos municípios, há a percepção entre alguns estudiosos de que o processo de descentralização de serviços públicos na área social, em particular os da educação, sejam uma imposição externa (KRAWCZYK, 2002; SOUZA \& FARIA, 2004; BOMFIM, 2011), parte de uma agenda estratégica e conceitual articulada internacionalmente e imposta, operacionalmente, por organismos internacionais, que desobriga o estado a cumprir sua função social para manter interesses econômicos, ao transferir suas responsabilidades para outros entes, estatais ou não.

No caso brasileiro, massificou-se a educação e gastou-se mais com sua implementação justamente a partir dos anos 1990. A obrigatoriedade e a cobertura da educação foram substancialmente expandidas, incorporando exatamente as camadas mais pobres e vulneráveis da população. O advento de mecanismos legais de vinculação de receitas e de redistribuição de recursos e a definição de escopo de despesas educacionais têm efetivamente aumentado as matrículas e os gastos com educação de nível básico, como mostram os dados do Ministério da Educação do Brasil ${ }^{15}$. Assim, há um certo desequilíbrio explicativo nos argumentos das pressões externas (mesmo que fossem os acordos internacionais, como os de Jomtien em 1990 (Unesco, 2000) e de Dakar em 2000 (Unesco, 2000), nos quais os países signatários, entre eles o Brasil, se comprometeram ${ }^{16}$ a aumentar a escolaridade de suas populações).

Não se pode, entretanto, deixar de reconhecer a influência externa nas estratégias dos governos nacionais e sub-nacionais dos países, mas analisá-las em uma dimensão ampliada.

Carnoy (2002) enfatiza a contribuição da educação para o desenvolvimento social e econômico na atualidade e reconhece o impacto da mundialização no setor:

15 Várias apresentações do Ministro Mercadante: http://portal.mec.gov.br/index.php?option=com_content\&view=article\&id=12224\&Itemid=380 16 As metas da iniciativa Educação para Todos são (http://www.un.org/en/globalissues/briefingpapers/efa/): Goal 1: Expand early childhood care and education;Goal 2: Provide free and compulsory primary education for all; Goal 3: Promote learning and life skills for young people and adults; Goal 4: Increase adult literacy; Goal 5: Achieve gender parity; Goal 6: Improve the quality of education 
. . . em muitos casos, esse fenômeno [a mundialização] tende a tornar-se um pretexto para os responsáveis pelas políticas na área da educação: daqui em diante, as mais diversas forças e fatores são atribuídos à mundialização e a seus efeitos indiretos. Se é verdade que um grande número de evoluções, ainda não bem identificadas, são devidas a tal fenômeno, temos de constatar que as políticas têm necessidade de instrumentos conceituais para que venha a ser discernido o que é realmente a mundialização e quais são suas verdadeiras repercussões. (CARNOY, 2002, pg.7) [grifo meu],

e agrupa as reformas em três conjuntos: as que enfatizam o ajuste estrutural, as que seguem pela descentralização da gestão e do financiamento ou as que optaram pela privatização. Em seu estudo chama atenção para a necessidade de um esforço coeso e sistemático do setor público, inclusive com o aumento de investimento e da regulação para garantir a equidade, de forma que suas populações possam colher os frutos da era da informação.

Rosar \& Krawczyk (2001) e Krawczyk (2002, 2005) análisam as reformas educacionais dos anos 1990 na América Latina, em particular Argentina, Brasil, Chile e México. Krawczyk (2005) resume a lógica delas:

"De uma forma ou de outra, as reformas que se iniciam nesta época ocorrem sob a lógica da "modernização", seguindo a tendência de toda a região, isto é, adaptar a educação às mudanças econômicas e de concorrência internacional. Neste sentido, propõe-se inovar não só as relações institucionais no interior do próprio Estado (que se mantém na liderança da implementação das reformas), mas também as parcerias com a sociedade civil.

Um dos eixos principais da reforma educacional, ocorrida nos anos 90 do século XX na América Latina, foi a consolidação de uma nova organização e governação do sistema educacional e da escola. Esta, ao adotar o princípio do mercado como indicador das realizações em todas as esferas sociais e ao ressignificar o conceito de cidadania enquanto consumidor, define formas quase mercantis de delegação de poderes e de relação com a demanda educacional. (KRAWCZYK 2005, pg. 803)

fazendo uma diferenciação entre as formas de decentralizar:

"Esse novo modelo de regulação supõe uma mudança radical da categoria 'sociedade civil' e 'cidadania' e vem sendo concretizado a partir de um processo de descentralização desenhado em três dimensões: descentralização entre os diferentes órgãos de governo (municipalização), 
descentralização para escola (autonomia escolar) e descentralização para o mercado (responsabilidade social)." (idem, Resumo)

O cenário é complementado por Arelaro (2007) que aponta significativos impeditivos de ordem interna e de contexto local para materializar a absorção da responsabilidade sobre o cotidiano escolar pelos municípios:

No processo turbulento e até irresponsável de municipalização de todo ou de parte significativa do ensino fundamental, seus dirigentes educacionais não conseguiram organizar, com um mínimo de condições objetivas e dignas de trabalho, um cotidiano escolar que favorecesse o florescimento de experiências pedagógicas singulares e interessantes nas suas redes públicas de ensino. (ARELARO, 2007, pg.915)

A precariedade técnica, administrativa e financeira dos municípios (a maior parte deles de porte minúsculo e sem renda própria ${ }^{17}$ ) pode, ainda, estar associada ao estímulo de "ações de terceirização da oferta e da privatização da educação municipal" por meio de, por exemplo "subvenção pública a vagas em estabelecimentos privados, assessoria privada para a gestão educacional e compra de "sistemas" de ensino". (ADRIÃO, 2009; 2012).

Efetivamente, há o risco de se potencializar ou perpetuar a precariedade técnica dos profissionais da educação das localidades mais frágeis e até de se deparar com o desaparecimento da possibilidade de matrícula, com a exacerbação da dependência do setor privado, como antecipa Adrião (2009): "Na ausência de regulações claras, a educação pública vem sendo incorporada às estratégias de ampliação e concentração do capital privado da área educacional".

A autora estuda em profundidade a aquisição, por parte dos municípios, de produtos e serviços educacionais comercializados por empresas e entidades filantrópicas ${ }^{18}$. A contribuição desses expedientes para mitigar as dificuldades locais já foi apontada, mas não foi comprovada (LEME, LOUZANO \&

17 Segundo o Censo de 2010 do IBGE, 85\% dos municípios do estado de São Paulo tinham até 10 mil habitantes, correspondendo a $21 \%$ da população do estado e 54 municípios concentram 50\% do Produto Interno Bruto do Brasil, sendo que outros 1.325 cidades compõem apenas $1 \%$.

18 Pela lei brasileira, entidades filantrópicas podem prestar serviços e vender produtos, desde que não distribuam seu superávit. 
PORTELA, 2012), e tem sua lógica apresentada por Adrião et al. (2009), como parte de um extenso projeto de pesquisa sobre o tema (ADRIÃO, 2011 ${ }^{19}$ ).

"A precariedade técnico-operacional encontrada nos municípios, frente às suas responsabilidades para com a oferta de educação básica, parece estar no cerne dessa busca de qualidade por meio da padronização. Os dirigentes municipais entrevistados reconhecem limites de natureza técnicopedagógica para se instituir um ensino de qualidade, tais como ausência de um quadro técnico qualificado para oferecer suporte ao trabalho desenvolvido nas unidades escolares, ou, ainda, precariedades na formação docente para as quais a alternativa seria o oferecimento de materiais apostilados, além de assessoria promovida pela instituição privada produtora do material. . . . Temos a considerar o fato de alguns dirigentes apontarem outros benefícios importantes como resultado da parceria. Estes se configurariam principalmente em ganhos eleitorais, uma vez que a população tenderia a identificar como indicador de qualidade educativa a vinculação da educação municipal a logotipos e marcas de escolas privadas. Em muitos casos, essa vinculação é associada a uma suposta democratização do acesso à educação de qualidade, uma vez que, aparentemente, são minimizadas as diferenças entre os mais ricos, que podem pagar pelos estudos, e os mais pobres, que precisam recorrer ao poder público. (ADRIÃO et al, 2009, pg. 811)

Essa peocupação é fundamental porque se a descentralização de responsabilidades e de recursos passarem a ser uma associação inevitável com o fechamento de negócios com o setor privado como aponta a autora, é bom termos em mente que, para qualquer mercado desregulamentado (ou pouco regulamentado para as oportunidades de ganho que oferece), o jogo empresarial assemelha-se à "lei da selva" ou à "sobrevivência do mais forte". Além disso, a separação da responsabilidade civil entre pessoas jurídicas e físicas faz com que, diferentemente do mundo animal, aquele que é mais fraco (ou perdulário, irresponsável ou criminoso) não pague com a própria vida (assemelha-se, entretanto não é a lei da selva!) sua incompetência (ou ganância, irresponsabilidade ou psicopatia), mas, frequentemente, com o prejuízo alheio, o que torna o risco - quase sempre maior para os incautos - tremendamente atrativo.

19 No relatório de pesquisa para a FAPESP, projeto no qual produziu um extenso banco de dados público com informaç̃es sobre todos os municípios de São Paulo, suas redes e o status de uso desse tipo de solução. Disponível em: http://www.fae.unicamp.br/greppe/bd/pesquisas/pesqdados.php 
Casos famosos e recentes, com consequências desastrosas e contabilizadas, como insolvência do banco de investimentos americano Lehman Brothers e, no caso da educação, o fechamento súbito da rede de escolas JB Education ${ }^{20}$ na Suécia, ou os com desdobramentos ainda a se avaliar, como o fechamento universidades Gama Filho e UniverCidade do Grupo Galileu ${ }^{21}$ no Rio de Janeiro, que deixou 34 mil

20 A falência, neste ano, da JB Education, controlada pela empresa dinamarquesa de "private equity" Axcel, foi o maior, mas não o único, caso do setor educacional sueco. O fechamento da JB custou o emprego de quase mil pessoas e deixou mais de 1 bilhão de coroas suecas (US\$ 150 milhões) em dívidas, principalmente com bancos e fornecedores. Os alunos de suas escolas ficaram abandonados. Uma em cada quatro escolas de ensino médio é deficitária e, desde 2008, o risco de insolvência subiu 188\% e é $25 \%$ superior à média das empresas suecas, disse a consultoria UC. "São poucos os setores que exibem cifras tão ruins como essas", disse a UC. Parte do problema resulta da distribuição etária da população, com os números totais das escolas secundárias sofrendo queda significativa desde 2008 e pouca probabilidade de voltar ao antigo nível por uma geração ou mais. A permissividade do ambiente regulatório também contribuiu. A Suécia substituiu um dos sistemas escolares mais rigidamente regulamentados do mundo por um dos mais desregulamentados, o que levou a escândalos como um caso de 2011 em que um pedófilo condenado pôde abrir várias escolas de forma absolutamente legal.

Quando uma das maiores empresas privadas de educação faliu, alguns meses atrás, deixou 11 mil alunos a ver navios e fez com que o governo da Suécia repensasse sua reforma pioneira da educação pública, aos moldes do mercado. O fechamentos de escolas e a piora dos resultados tiraram o brilho de um modelo de educação admirado e imitado em todo o mundo, em especial no Reino Unido. "Acho que acreditamos cegamente demais na possibilidade de mais escolas privadas garantirem maior qualidade da educação", disse Tomas Tobé, diretor da comissão de educação do Parlamento e porta-voz de educação do governista Partido Moderado.

No país de crescimento mais acelerado da desigualdade econômica entre todos os membros da Organização para a Cooperação e Desenvolvimento Econômico (OCDE), os aspectos básicos do mercado escolar desregulamentado estão agora sendo reconsiderados, levantando interrogações sobre o envolvimento do setor privado em outras áreas, como a de saúde. Duas décadas após o início de seu experimento de livre mercado na educação, cerca de $25 \%$ dos alunos do ensino médio da Suécia frequentam agora escolas financiadas com recursos públicos, mas administradas pela iniciativa privada. Essa proporção é quase o dobro da média mundial. Quase metade desses alunos estudam em escolas parcial ou totalmente controladas por empresas de "private equity", que compram participações em outras empresas. Na expectativa das eleições do ano que vem, políticos de todos os matizes estão questionando o papel dessas empresas, acusadas de privilegiar o lucro em detrimento da educação, com práticas como deixar alunos decidirem quando aprenderam o suficiente para passar e não manter registro de notas. As escolas privadas introduziram muitas práticas antes exclusivas do mundo corporativo, como bônus por desempenho para funcionários e divulgação de anúncios no sistema de metrô de Estocolmo. Ao mesmo tempo, a concorrência pôs os professores sob pressão para dar notas mais altas e fazer marketing de suas escolas. No início, imaginava-se que a participação privada na educação se daria por meio de escolas geridas individualmente e em nível local. Poucos vislumbraram que haveria empresas de "private equity" e grandes corporações administrando centenas de unidades. Fonte: Jornal Valor Econômico. 11/12/2013. Acesso em 20/1/2014.

$21 \mathrm{O}$ Ministério Público Federal pediu à Polícia Federal a instauração de inquéritos para investigar a gestão do grupo Galileo à frente das universidades Gama Filho e UniverCidade, do Rio, descredenciadas esta semana (jan 2014) pelo Ministério da Educação (MEC). O objetivo é apurar suspeitas de gestão fraudulenta e lavagem de dinheiro. O grupo pode não ser o único alvo de investigações nesse caso. O deputado estadual Paulo Ramos (PSOL) afirmou ontem que pedirá, na próxima semana, que o Ministério Público Federal apure a atuação do MEC no descredenciamento das duas instituições. Para ele, pode haver interesse de funcionários do MEC em beneficiar alguma instituição privada com a decisão. Com o descredenciamento, os cerca de 9,5 mil alunos da Gama Filho e UniverCidade serão transferidos para outras instituições. O procedimento será guiado pelo MEC.

Ramos foi presidente da CPI das Universidades Privadas, criada na Assembleia Legislativa do Rio em 2012 para apurar irregularidades nas instituições. O relatório final da CPI, enviado ao MEC em setembro de 2013, pedia a intervenção do ministério na gestão das duas universidades. "Pedimos a intervenção do MEC para que houvesse o acompanhamento da situação do grupo Galileo, mas não o descredenciamento", disse.

A Gama Filho enfrenta problemas financeiros há mais de uma década. Um dos motivos que levaram a família fundadora a acumular dívidas foi o plano de abrir unidades fora do bairro de origem, Piedade, no Rio. Em 2010, após coordenar o curso de direito e prestar serviços para a escola, o advogado Marcio André Mendes Costa, negociou com a família Gama Filho a transferência da universidade para sua empresa, a Galileo. Com a ajuda do Banco Mercantil, Costa fez um empréstimo e montou uma emissão de debêntures de R \$ 100 milhões. Os papéis foram vendidos a fundos de pensão, como Postalis e Petros. Parte do dinheiro foi usada para pôr outra instituição carioca, a UniverCidade, também endividada, no portfólio da Galileo. Fonte: Jornal Valor Econômico. 14/1/2014 e 20/1/2014. Acesso em 20/1/2014. 
alunos sem ter onde estudar e mais de mil graduados sem diploma, são exemplos concretos de que há grandes riscos em delegar, com pouco ou nenhum controle, o destino e os interesses da população nas mãos de poucos.

Embora a colaboração entre instituições públicas e privadas não seja, em si, um pecado capital, sem uma regulação e mecanismos de proteção jurídica e financeira competentes, é muito difícil, principalmente em contextos de precariedade técnica e administrativa como os de muitos municípios, alinhar objetivos, monitorar práticas e garantir resultados quando o setor público e o privado trabalham juntos.

Em um país em desenvolvimento como o Brasil, que arrasta historicamente limitações de toda sorte em relação à população e aos gestores que dela emanam, vencer o círculo vicioso da precariedade em nível local passa a ser crucial, quer a gestão seja totalmente pública, ou compartilhada com a comunidade ou arranjos institucionais diversos.

Não só as parcerias público-privadas, mas mesmo a descentralização em si pode resultar em efeito reverso do desejado, como foi apontado por Prud'homme (1995), sob a perspectiva das teorias econômicas em países emergentes. O autor se refere ao mecanismo de desconcentração política, fiscal e técnica de políticas públicas como um potente remédio que, aplicado nas doses e no contexto certo, pode ter o efeito salutar esperado, mas que em doses e em contextos errados, pode fazer mais mal que bem. Seus argumentos sustentam que a descentralização pode aumentar as disparidades e "ser a mãe da segregação" ${ }^{22}$, por em risco a estabilidade macroeconômica (no caso da descentralização fiscal ${ }^{23}$ ), e prejudicar a eficiência (de alocação de recursos ${ }^{24}$ ), (pgs. 202-203).

22 A third point is that poor people in low-income regions are poor for good reason: they live in a place that offers fewer economic opportunities and less infrastructure and lacks economies of agglomeration and other location-specific externalities. Raising individual incomes is not the same thing as increasing the development potential of the area. It cures the symptoms rather than the illness.

23 The two main instruments of macroeconomic policy are monetary policy and fiscal policy. Fiscal policy-that is, control over the amount and structure of taxes and expenditures and the management of the budget deficit (or surplus) - is a very powerful instrument for stabilizing the economy. It is an instrument that only the central government can manipulate, because local authorities have few or no incentives to undertake economic stabilization policies.

24 The case for centralization is usually based on efficiency. The argument provided by the theory of fiscal federalism is that the inhabitants of the different jurisdictions have different tastes: in local government A, people prefer recreation, but in local government B, they prefer education. The same provision of education and recreation in A and B will satisfy neither. Decentralized provision, on the contrary, will make it possible to give the residents of A 
Neste breve percurso sobre descentralização fica a certeza de que esse é um tema que não pode ser simplificado, ainda mais quando está relacionado a outro complexo que é a provisão de serviços de educação de qualidade em larga escala. Entretanto, apesar de sua compreensão ficar muito limitada se não recorrermos a mais de uma área de conhecimento, não é um enigma intransponível, pois há um ponto comum entre as diferentes abordagens teóricas: a necessidade de se mapear, sistematizar e analisar a grande variedade de realidades locais para que os remédios possam ser corretamente selecionados e aplicados.

Passamos assim, para a última vertente do debate tipificado por Araújo e a de maior relevância para este estudo, que é a que reune os trabalhos que tenham como componente de análise principal, ou relevante, os contextos locais dos processos de municipalização. Antes de apresentar o que este conjunto de trabalho contribui ou suscita, é importante diferenciar a descentralização da educação de acordo com o que propõe Abreu (2003). A autora divide a municipalização em antes de depois da década de 1990, ou pré e pós Fundef/b (ou ainda, complementando, antes/depois da democratização, da nova Constituição e dos mecanismos de vinculação e de distribuição de recursos estatais), quando houve "inversão da lógica de transferência de encargos sem recursos", fazendo o seguinte histórico:

. a educação foi realmente massificada no Brasil apenas no final do séc. XX e no início do seguinte. Em termos internacionais, foi um processo rápido mas atrasado, que incorporou por último as camadas mais pobres e isoladas da população. Esse contingente "retardatário" foi absorvido em maior proporção pelos municípios que pelos estados, principalmente por uma questão de restrição de recursos (e de interesse) por parte destes;

. a partir dos anos 1970, em paralelo com a massificação, começa também o processo de transferência de matrículas dos estados para seus municípios, com a preocupação direcionada mais para a melhora das contas públicas que da 
educação propriamente dita. Municípios politicamente mais frágeis cederam mais às pressões de transferência, ou simplesmente de expansão compulsória, que os que tinham maior poder de barganha;

. dessa forma, em 1997, ano anterior ao início do funcionamento do Fundef, a região com maior taxa de municipalização era o Nordeste, com 57,3\% e a menor estava na região Sudeste, com 28,6\%; entre os estados, havia o grupo menos municipalizado formado por São Paulo (18,8\%), Minas Gerais (26,3\%) e Espírito Santo $(30,2 \%)$ e os altamente municipalizados: Piauí $(60,0 \%)$, Ceará $(64,3 \%)$, Maranhão (67,8\%) e Alagoas (73,2\%). O Rio de Janeiro, que teve sua capital (exDistrito Federal) incorporada ao estado, com as matrículas automaticamente municipalizadas, tinha $64,9 \%$, uma vez que a capital respondia pela maior parte delas.

Depreende-se então que, após o advento do Fundef/b, o dinheiro "segue o aluno" e o simples "descarte" deles do estado para seus municípios diminui sensivelmente, uma vez que às matrículas foi atrelado algum recurso. Os trabalhos selecionados para melhor compreender os diferentes contextos em que a transferência de matrículas ocorreu no Estado de São Paulo têm duas caraterísticas principais: descrevem o processo em contexto local de cidades ou grupo delas e são mais recentes, com um lapso temporal mínimo de 10 anos desde o início do processo em 1995. Assim, pode-se, por meio deles, compreender não só características de implementação, como suas consequências, pelo menos no que diz respeito às alterações de gestão da educação durante e após cada processo de municipalização.

Eles estão ordenados por ano de publicação e resumidos segundo a relevância de suas informações para a presente pesquisa. Foram selecionadas dissertações ou teses que descrevessem com detalhes questões locais diretamente relacionadas ao desafio de receber/criar vagas no ensino fundamental e implementar um sistema de educação. 
Lucio (2005) faz uma análise com ênfase referências de desenho de políticas públicas $^{25}$ e nas características de pré-condição para implementação propostas por Dagnino $^{26}$, além de apresentar na bibliografia a listagem dos instrumentos legais utilizados nos processo em cada uma das cidades, o que facilita a compreesão de sua implementação. Contextualizou cada uma delas dos pontos de vista histórico, político, econômico e populacional, antes de descrever, em detalhes, cada um dos processos, resumidos as seguir.

25 VIANA, Ana Luiza . Abordagens metodológicas em políticas públicas. RAP - Revista de Administração Pública. Fundação Getúlio Vargas. Rio de Janeiro. 30 (2) 5-43. MAR/ABR. 1996.

26 DAGNINO, Renato et alii: Gestão Estratégica de Inovações: Metodologias para análise e implementação. Taubaté: Editora Cabral Universitária, 2002. (p.34) 
Tabela 1: Municípios analisados por Lucio (2005) e características dos processos de municipalização

\begin{tabular}{|c|c|c|}
\hline Município & Processo & Situação dos docentes \\
\hline Mococa & $\begin{array}{l}\text { Não aderiu ao convênio do estado. } \\
\text { Municipalizou somente escolas do } \\
\text { meio rural, expandindo a } \\
\text { municipalização, logo após, para } \\
\text { o meio urbano. Legislação } \\
\text { acompanhou as necessidades do } \\
\text { processo. Quadros de apoio } \\
\text { formados nos } 3 \text { primeiros anos. }\end{array}$ & $\begin{array}{l}\text { Houve sobre de docentes do } \\
\text { estado, que não foram absorvidos } \\
\text { pelo município, com acomodação } \\
\text { local. Formação continuada e } \\
\text { contratação de Coordenadores } \\
\text { Pedagógicos. Gratificações com } \\
\text { sobras do FUNDEF. Até } 2003 \\
\text { não tinha aprovado plano de } \\
\text { carreira. }\end{array}$ \\
\hline $\begin{array}{l}\text { São José do } \\
\text { Rio Pardo }\end{array}$ & $\begin{array}{l}\text { Não assinou } \\
\text { estabeleceu matrícula convênio, } \\
\text { com o Estado, dado contar com } \\
\text { rede própria. Legislação } \\
\text { acompanhou as necessidades do } \\
\text { processo. Quadros de apoio } \\
\text { formados nos } 3 \text { primeiros anos. }\end{array}$ & $\begin{array}{l}\text { Não houve sobra porque tinha } \\
\text { rede própria. Formação } \\
\text { continuada e contratação de } \\
\text { Coordenadores Pedagógicos. } \\
\text { Gratificações com sobras do } \\
\text { FUNDEF. Até } 2003 \text { não tinha } \\
\text { aprovado plano de carreira. }\end{array}$ \\
\hline $\begin{array}{l}\text { São } \\
\text { Sebastião da } \\
\text { Grama }\end{array}$ & $\begin{array}{l}\text { Assinou convênio municipalizou } \\
\text { as escolas do meio rural e as } \\
\text { escolas do meio urbano de } 1 .^{\mathrm{a}} \text { a } 4 .^{\mathrm{a}} \\
\text { séries do Ensino Fundamental, } \\
\text { mantendo classes multisseriadas } \\
\text { de } 1 .^{\mathrm{a}} \text { a } 4^{\mathrm{a}} \text { séries no meio rural. } \\
\text { Contava com base legal aprovada, } \\
\text { à exceção do Estatuto do } \\
\text { Magistério (aprovado apenas em } \\
\text { 2005). Quadros de apoio } \\
\text { formados nos } 3 \text { primeiros anos. }\end{array}$ & $\begin{array}{l}\text { Sobra com remoção compulsória } \\
\text { para cidades próximas. Formação } \\
\text { continuada e contratação de } \\
\text { Coordenadores Pedagógicos. } \\
\text { Gratificações com sobras do } \\
\text { FUNDEF. Até } 2003 \text { não atendia } \\
\text { os anos finais. Até } 2003 \text { não tinha } \\
\text { aprovado plano de carreira. }\end{array}$ \\
\hline Tapiratiba & $\begin{array}{l}\text { Assinou convênio e recebeu } \\
\text { alunos, docentes efetivos e } \\
\text { prédios equipados. Legislação } \\
\text { acompanhou as necessidades do } \\
\text { processo. Quadros de apoio } \\
\text { formados nos } 3 \text { primeiros anos. }\end{array}$ & $\begin{array}{l}\text { Sobra com remoção compulsória } \\
\text { para cidades próximas. Formação } \\
\text { continuada e contratação de } \\
\text { Coordenadores Pedagógicos. } \\
\text { Gratificações com sobras do } \\
\text { FUNDEF. Até } 2003 \text { não atendia } \\
\text { os anos finais, Até } 2003 \text { não tinha } \\
\text { aprovado plano de carreira }\end{array}$ \\
\hline
\end{tabular}

Em relação às pré-condições propostas por Dagnino: 
Tabela 2: Municípios analisados por Lucio (2005) e condições de implementação da política pública

\begin{tabular}{|c|c|c|c|c|}
\hline Pré-condições & Mococa & $\begin{array}{ll}\text { S.J. } & \text { Rio } \\
\text { Pardo } & \\
\end{array}$ & $\begin{array}{ll}\text { S.S. } & \text { da } \\
\text { Grama } & \\
\end{array}$ & Tapiratiba \\
\hline $\begin{array}{l}1-\text { que os responsáveis pela } \\
\text { implementação de municipalização } \\
\text { não imponham restrições muito } \\
\text { severas ao programa }\end{array}$ & Ok & Ok & $\begin{array}{l}\text { APEOESP } \\
\text { fez violenta } \\
\text { oposição }\end{array}$ & $\begin{array}{l}\text { Oposição dos } \\
\text { docentes } \log 0 \\
\text { debelada }\end{array}$ \\
\hline $\begin{array}{l}\text { 2- que haja tempo adequado e } \\
\text { recursos suficientes à disposição do } \\
\text { programa28 }\end{array}$ & Ok & Ok & $\mathrm{Ok}$ & Ok \\
\hline $\begin{array}{l}3 \text { - que não haja restrições em termos } \\
\text { de recursos globais e se a política for } \\
\text { implementada por etapas, que os } \\
\text { recursos sejam garantidos em cada } \\
\text { etapa }\end{array}$ & Ok & Ok & Ok & Ok \\
\hline $\begin{array}{l}4 \text { - que haja uma única agência de } \\
\text { implementação e que as relações de } \\
\text { dependência sejam pequenas em } \\
\text { número e importância }\end{array}$ & $\begin{array}{l}\text { Parcial - } \\
\text { escolas com } \\
\text { autonomia } \\
\text { pedagógica, } \\
\text { mas não } \\
\text { orçamentária, } \\
\text { a não ser } \\
\text { pelas APMs }\end{array}$ & $\begin{array}{l}\text { Parcial - } \\
\text { escolas com } \\
\text { autonomia } \\
\text { pedagógica, } \\
\text { mas não } \\
\text { orçamentária, } \\
\text { a não ser } \\
\text { pelas APMs }\end{array}$ & $\begin{array}{l}\text { Parcial - } \\
\text { escolas com } \\
\text { autonomia } \\
\text { pedagógica, } \\
\text { mas não } \\
\text { orçamentária, } \\
\text { a não ser } \\
\text { pelas APMs }\end{array}$ & $\begin{array}{l}\text { Parcial - } \\
\text { escolas com } \\
\text { autonomia } \\
\text { pedagógica, } \\
\text { mas não } \\
\text { orçamentária, } \\
\text { a não ser } \\
\text { pelas APMs }\end{array}$ \\
\hline $\begin{array}{l}5 \text { - que haja entendimento completo } \\
\text { e, consentimento, acerca dos } \\
\text { objetivos a serem atingidos durante } \\
\text { todo o processo de implementação }\end{array}$ & Não houve & Não houve & Não houve & Não houve \\
\hline $\begin{array}{l}6 \text { - que ao mobilizar-se para o } \\
\text { cumprimento de objetivos acordados } \\
\text { seja possível especificar, em } \\
\text { completo detalhe e perfeita } \\
\text { sequência, as tarefas a serem levadas } \\
\text { a cabo por cada participante do } \\
\text { programa }\end{array}$ & Confusão & Confusão & $\begin{array}{l}\text { Estabelecidas } \\
\text { no conênio } \\
\text { com a SEESP }\end{array}$ & $\begin{array}{l}\text { Estabelecidas } \\
\text { no conênio } \\
\text { com a SEESP }\end{array}$ \\
\hline $\begin{array}{l}7 \text { - que haja perfeita comunicação e } \\
\text { coordenação entre os vários } \\
\text { elementos envolvidos no programa }\end{array}$ & Confusão & Confusão & Confusão & Confusão \\
\hline $\begin{array}{l}8-\text { que aqueles com autoridade } \\
\text { possam exigir e obter perfeita } \\
\text { obediência }\end{array}$ & Ok & Ok & Ok & Ok \\
\hline
\end{tabular}

Segundo o autor, a descentralização contribuiu para melhorar o processo ensino-prendizagem nestes municípios pois eles investiram boa parte dos recursos financeiros na compra de material didático e pedagógico e no acervo das bibliotecas; na capacitação dos professores, com previsão de afastamento remunerado e progressão por títulos; previsão para formação em serviço e horas 
de trabalho pedagógico; na inclusão de alunos com necessidades especiais e na atenção particular para alunos com dificuldades na aprendizagem. Além de investir nas instalações prediais, no provimento de cargos de especialistas da educação, colocando em todas as escolas de Mococa, São José do Rio Pardo e Tapiratiba, no mínimo, um Coordenador Pedagógico e dois Coordenadores Pedagógicos para as escolas rurais e urbanas em São Sebastião da Grama. As diferenças de implementação entre os municípios são explicadas por características geográficas, que impediram a nucleação das escolas rurais em Tapiratiba, por exemplo; políticas, que facilitam a municipalização em Tapiratiba porque o Prefeito estava alinhado com o Gabinete da SEESP e, ao contrário, em Rio Pardo, onde a APEOESP levou ao processo de municipalização em rede própria.

Sousa (2005) descreve o processo de municipalização nas cidades de Catanduva, Mauá e Lins, a partir de um detalhado relato da descentralização educacional e da municipalização das matrículas no Estado de São Paulo como um todo, fazendo um paralelo com a formação do Partido do Trabalhadores, da evolução de sua agenda educacional e de sua atuação nos três municípios escolhidos como estudo de caso. Os três municípios, geridos em continuidade por militantes do Partido, optaram por não municipalizar as matrículas, mas por criar redes próprias, o que se explica pelas ligações políticas dos prefeitos com o Sindicato Estadual dos Docentes, APEOESP. Os três escolheram dar prioridade à educação infantil e à de jovens e adultos, o que fez com que as matrículas municipais para os anos iniciais do ensino fundamental estabilizassem (até o ano de 2003), respectivamente, nas faixas de $25 \%, 3,2 \%$ e $6,2 \%$.

Siqueira (2006) analisou os processos de recrutamento e seleção de professores dos anos iniciais do ensino fundamental na cidade de Jundiaí após a municipalização do ensino na cidade, em 1996 com 26 escolas, que, juntamente com Santos e Ilha Solteira foram as "pioneiras" do processo em São Paulo. Faz a análise de seu ponto de vista como professor da rede estadual em outra cidade, Caieiras, com a indagação inicial se os processos de municipalização estariam contribuindo ou não para a profisssionalização dos docentes e da estabilidade do 
exercício da profissão e também para a fragmentação do exercício sindical docente no estado.

$\mathrm{O}$ autor parte de um contraponto entre o ponto de vista da APEOESP apresentado em uma publicação conjunta do Sindicato com a Ação Educativa (2001) e o de Guiomar Namo de Mello (1993) para apresentar seu trabalho. Confrontou a documentação relativa aos dois tipos de contratação local, concursos e escalas rotativas (temporários para períodos intervalados de seis meses, com avaliação de mérito profissional), com questionários para determinar o perfil profissional dos docentes temporários da cidade, que são contratados pela CLT $^{29} \mathrm{e}$ não contam com estabilidade funcional. Constatou que são pessoas mais jovens e com menor experiência profissional, de formação mais precária, sem outra opção profissional, mas com maioria residente na própria cidade, que optam por participar dessa modalidade de contratação para dar aulas de inglês e de educação física.

No período de análise (1996-2005) foram feitos três concursos e seis seleções para escalas rotativas, fazendo com que o corpo docente da cidade seja composto por $54 \%$ de concursados e estáveis e $17 \%$ de afastados do estado (que foram municipalizados com salários equiparados aos da rede estadual) e $28 \%$ de contratados por escala rotativa. Entretanto, o autor não apresenta a composição do tipo de contratação no município pré-municipalização, apenas a do estado em 2006, que era de $45 \%$ de não efetivos.

Finaliza concluindo que a política de contratação em caráter temporário está sendo revista, mas que foi uma opção "além de [ser] mais econômica para a prefeitura, também possibilita o maior controle dos dirigentes locais em relação à composição e atuação do corpo docente.", mas que APEOESP tem um argumento válido de que um sindicato maior tem mais condições de resistir à precarização da condição docente em nível local.

29 Consolidação das Leis Trabalhistas, legislação que regulamenta as condições de trabalho do setor privado. 
Figueiredo (2008) apresenta a implementação do sistema de avaliação externa local da cidade de Cosmorama (Sarem - Sistema de Avaliação do Rendimento Escolar Municipal de Cosmorama,), cuja educação foi municipalizada em 2001. A cidade conta com duas escolas, uma municipal para os anos iniciais do ensino fundamental e uma estadual, para os anos finais. A cidade utiliza material apostilado privado, mas o sistema de avaliação foi desenvolvido pelos próprios docentes. O sistema de avaliação educacional local complementa os do Estado (Saresp) e o do Governo Federal - Prova Brasil - e é aplicado anualmente desde 2002. As avaliações municipais mostram, segundo a autora, uma evolução positiva do aprendizado dos alunos, como consequência do investimento em ações e projetos de qualidade educacional, sem que fique claro o mecanismo de indução da qualidade que eles aportam. Aponta também que os alunos mais vulneráveis são os que têm mais dificuldades de apresentar melhoras, mas relata que o esforço de se avaliar os alunos localmente, com o envolvimento das escolas e docentes propiciou a disponibilização de informações que foram úteis ao redirecionamento das ações pedagógicas no município e conclui que, mesmo a municipalização tendo sido um movimento externo aos municípios, ensejado por organismos multilaterais, esses podem reagir, não só ao criar seus sistemas educacionais próprios, mas também ao avaliá-los e aprimorá-los.

Macedo (2008) escolheu o tema da supervisão escolar municipal tendo sido a autora a primeira a ocupar o cargo na cidade de Valinhos a partir de 2002, na segunda fase da municipalização das escolas, que passou também ao controle local as escolas dos anos finais do ensino fundamental. A autora parte de conceitos de racionalidade e burocracia de Weber argumentando que a constituição de uma ordem legal racional e da burocracia se contrapõem à irracionalidade e à tradição arcaica pré-capitalista, a qual usa para fazer um paralelo com a realidade de sua cidade durante a implementação da municipalização, cujo processo formal apresenta quase como um folhetim, mas cujos relatos anedóticos revelam o patrimonialismo e personalismo vigentes na gestão educacional local.

Militão (2008) apresenta o processo de municipalização da Região Administrativa de Marília, que, na sua opinião foi essencialmente motivado pela 
implementação do Fundef, uma vez que as matrículas em redes locais eram escassas antes do início do processo, o que levaria os municípios a perdas expressivas de receita. Os relatos resumidos de cada muncípio mostram principalmente questões operacionais na transferência dos prédios e docentes e que a maior parte deles aderiu logo ao processo de transferências de prédios, alunos e docentes, com exceção dos municípios de Garça e Marília que formaram redes próprias por razões diferentes. A primeira cidade, aparentemente por uma opção política e a segunda por uma questão de patrimônio, uma vez que já era proprietária dos prédios nos quais estavam instaladas as escolas estaduais originais. O autor relata ainda a ausência de debates e de informação apropriada sobre o processo de municipalização a pais, docentes e interessados, tendo sido uma decisão tomada entre a Prefeitura e o Governo Estadual, com alguma resistência inicial por parte de docentes e do sindicato estadual (APEOESP), logo superada. Segue apresentando mais detalhes sobre a implementação dos demais componentes do processo de municipalização como a criação dos Conselhos Municipais de Educação e de acompanhamento do Fundef, que em boa parte dos municípios parecem estar funcionando sob a influência direta das prefeituras e não como colegiados independentes. A realização imediata dos concursos públicos para seleção de docentes também foi cumprida apenas por uma parte dos municípios que adequaram a contratação deles aos esquemas legais já vigentes em cada localidade, o que também impactou na criação dos planos de carreira de magistério.

Outro ponto analisado pelo autor é a preferência das prefeituras em absorver alunos nos anos iniciais do ensino fundamental, quando apenas pela questão do Fundef não haveria diferença em relação a que etapa municipalizar. Seriam duas explicações, uma de que agregar alunos nos anos iniciais seria uma tarefa mais simples pela própria dinâmica educacional dessa etapa e também porque, à época das entrevistas, o futuro do Fundef e da disposição política do estado em manter as condições para promover municipalização adicional não eram claras. $\mathrm{O}$ autor conclui que, mesmo com o advento do Fundeb, que inclui as modalidades de ensino que tinham ficado de fora no Fundef, o mecanismo pouco pode fazer pela melhoria da educação, uma vez que apenas distribui melhor os recursos existentes, sem agregar mais nenhum. 
Moraes (2009): A autora foi a própria Secretária de Educação do município de Itirapina durante boa parte do tempo em que se concentra a análise (19972008), faz uma longa revisão bibliográfica e histórica da organização da educação no Brasil para depois descrever uma década de municipalização no município, que começou em 1997 com a criação de turmas próprias de $1^{\text {a }}$ série para acomodar crianças oriundas da rede de educação infantil da cidade que não tinham idade ${ }^{30}$ para entrar nas duas escolas estaduais da cidade e com a criação dos Conselhos Municipal de Educação e de Acompanhamento do Fundef. A Câmara local aprovou por unanimidade a assinatura do convênio com o estado, com pouca oposição ao processo. No ano seguinte começam os repasses do Fundo, a princípio sem ônus para a cidade. Entretanto, no mesmo ano, há um aditamento ao convênio obrigando o município a reembolsar ao estado $20 \%$ dos custos dos professores, o que é feito novamente em 2002, passando o percentual de reembolso para 100\%. Para cada obstáculo não previsto são criadas leis e acomodações administrativas à medida que o tempo passa. Em 2004 o Plano Municipal de Educação é aprovado na Câmara. No período da análise - 1998 a 2008, com a expansão das matrículas e a diminuição do número médio de alunos por turma (de 35 para 25, contra 37 para 33 na escola estadual), a rede chega a cinco unidades de ensino fundamental, sendo duas em período integral e apenas uma escola estadual.

Os professores temporários do estado são contratados pelo município e o primeiro concurso realizado em 2008. A autora também relata que a gestão fez em 2006 a opção pelo uso de sistema apostilado de ensino em substituição ao PNLD por questões de logística, recorrendo à empresa COC no primeiro momento, que foi substituída pelo sistema Positivo dois anos depois. O uso de apostilas agradou ao pais, mas desagradou aos professores. A cidade participa do SARESP e da Prova Brasil desde 2005. 
Conclui que considera a experiência "bem-sucedida", dos pontos de vista da autonomia local, da proximidade com os usuários, da flexibilidade e do aumento de recursos que proporcionaram melhores condições físicas às escolas da cidade.

Espósito (2010) analisa a implementação da municipalização na cidade de Martinópolis, a partir de entrevistas com profissionais da Secretaria de Educação e de escolas da rede, com os dados das avaliações em larga escala aplicadas no estado, SARESP e Prova Brasil, fez uma detalhada análise da evolução da proficiência dos alunos. A autora apurou nas entrevistas que a cidade investiu em "política de formação do magistério, contratação por meio de concurso público, capacitação dos docentes, escolas reformadas e adequadas à situação de ensino, disponibilidade de recursos (TV, DVD e máquina xerox), equipe multidisciplinar na área da saúde, que trabalha em conjunto com a educação (psicólogo, fonoaudiólogo, médicos e dentistas), sincronismo entre o departamento de educação e os demais departamentos da Prefeitura, Conselhos Municipais (de Educação, Fundeb e conselho da escola) atuantes, transparência nas ações e clima organizacionais positivo nas escolas pesquisadas", todas elas valorizadas pelos entrevistados. A contratação de sistema privado apostilado foi valorizada pelos profissionais da Secretaria, mas criticada por parte dos profissionais das escolas. Os resultados das avaliações mostram melhorias pontuais no SARESP e involução nas edições da Prova Brasil. A autora conclui que embora o município tenha avançado nas providências para melhorar a qualidade da educação oferecida a sua população, elas não foram suficientes para impactar positivamente no desempenho dos alunos.

Pupo (2012) descreve a municipalização no município de Campinas, sob o ponto de vista da introdução do Fundef e sua relação com a formação docente em nível local. A cidade diferencia-se da maior parte das demais por contar à época do início da municipalização com alto orçamento para a educação, que permitia um gasto por aluno da ordem de $\mathrm{R} \$ 2500,00$, já em 1998 , quando o percapita nacional do Fundo para os anos iniciais do ensino fundamental era de $\mathrm{R} \$ 315,00$. Mas o município acaba perdendo recursos pois não recebe mais alunos pelo processo de descentralização do governo estadual, nem os absorve em sua rede própria. $\mathrm{O}$ trabalho mostra um ponto recorrente da implementação do Fundef, que 
foi a diminuição relativa de recursos entre as etapas cobertas e as não cobertas pelo Fundo, mas acaba por passar ao largo do objetivo central que era descrever as alterações na formação docente. O comentário mais relevante é que a permissividade do horário de trabalho pedagógico fora de sala de aula quanto a não ser obrigatória, acaba diminuindo a disponibilidade de docentes para formações (que, segundo a autora não são formuladas de forma a atender às necessidades da rede, muito menos, planejadas) e os dados que mostram salários docentes bem acima da média para a realidade nacional.

Ramos (2013) valeu-se de entrevistas com profissionais das redes de MonteMor e Sumaré para avaliar a formação docente nas duas cidades após a municipalização. Ambas utilizam sistemas apostilados privados e baseiam a formação docente em seus conteúdos, além de terem toda sua regulação influenciadas pelas empresas prestadoras de serviço. Em Monte-Mor, chama atenção para a instalação, em todas as salas de aula, de lousas digitais e na ênfase que a formação docente no período deu para as orientações de uso do equipamento. Além disso, o município conta com uma série de parcerias com ongs e com o Governo Estadual e Federal, sem que a coordenação de todas as contribuições que elas possam ter dado tenha ficado esclarecida no trabalho. No lado positivo, a cidade conta com plano de carreira e remuneração que parece satisfazer a comunidade docente, aliado a um sistema permanente de avaliação que aborda as seguintes dimensões: cumprimento do currículo/ livro integrado; planejamento de aulas semanais/ quinzenais; elaboração e correção das avaliações; organização e didática; assiduidade e pontualidade; relacionamento com os discentes. A cidade de Sumaré também organizou seu sistema educacional com a municipalização, utiliza vouchers para a educação infantil e remunera seus docentes com padrões mais baixos que em Monte-Mor. Embora a autora seja muito crítica em relação ao uso do sistema apostilado privado e demais parcerias, não conseguiu estabelecer de forma clara seu impacto negativo, uma vez que, em ambas as cidades os indicadores educacionais vêm melhorando no período analisado (2000 a 2010) além de apontar, na pg. 179, que a escolha de um sistema unificado privado na cidade de Sumaré foi a solução encontrada pelo gestor e sua equipe para amenizar as diferenças predominantes por anos no município, no qual 
as escolas de bairro tinham acesso a educação de qualidade muito diferente das do centro.

Este levantamento bibliográfico permitiu o contato com detalhes da complexidade envolvida na implementação de um sistema educacional público de qualidade, que no caso brasileiro está sendo concebido como uma empreitada de natureza local, necessariamente fragmentada e inserida em um contexto nacional gigantesco e diverso. As explicações para se conceber a educação a partir de instâncias mais periféricas e frequentemente frágeis sob vários pontos de vista, foram o centro do debate durante a maior parte do tempo do período recente da história educacional brasileira. Simplificadamente, encontrou-se, de um lado, o Governo Federal e os governos estaduais tentando se livrar do ônus operacional e financeiro de se responsabilizar por milhões de alunos, professores e profissionais. De outro, sindicalistas e docentes procurando proteger suas conquistas profissionais e seus espaços de exposição política. Ao mesmo tempo, compromissos soberanos externos forçam o Governo Federal a aumentar a escolarização da população, além das pressões populares internas que vão na mesma direção.

A leitura das obras evidenciou uma atenção mais demorada de seus autores nos aspectos formais do controle das matrículas e da situação docente do que nas condições de ensino ofertadas aos alunos ou na análise de condicionantes que permitissem a estabilização da prestação de serviços educacionais de qualidade, quer pelo estado, quer pelos municípios.

As obras citadas no início do capítulo, que apontavam a descrença dos autores na existência de um interesse genuíno de políticos e autoridades educacionais brasileiras na efetiva mobilização de esforços materiais, humanos e políticos em prol de uma educação voltada para a emancipação individual e para a concussão de objetivos estratégicos da nação (Souza, Plank e Azanha, por exemplo) ficaram recorrentemente gravitando nos meus pensamentos enquanto analisava os relatos de campo. 
As descrições de contexto de municipalização consolidaram a impressão de que, no radar dos formuladores de política educacional, os alunos são vistos mais como coadjuvantes do que como essência de seu trabalho. Essa distância dos estudantes do cerne da atenção profissional acaba desviando, em alguma medida, as bússolas acadêmicas, com os trabalhos analisados traçando apenas vagamente a ponte entre o desenho burocrático e institucional da educação no município e o aprendizado dos alunos. A necessidade de renovação dos temas frente aos desafios atuais do país é apontada por Alves (2009):

Para além da filiação filosófica e partidária, os temas precisam ser discutidos à luz dos resultados de experiências nacionais e internacionais. Por certo, o Brasil é um país muito diverso e complexo, e não se trata de prescrever para o contexto brasileiro políticas que se mostraram eficazes em outros contextos. No entanto, a própria complexidade e a prórpia diversidade da realidade brasileira demandam maior inovação, diversificação e a avaliação das politicas educacionais praticadas. (ALVES, 2009, pg.160)

$[\ldots]$

Face ao desenvolvimento recente da educação brasileira, não há base sólida para esperar grandes novidades positivas nas próximas décadas. Isso deve ser considerado como mais uma razão para a renovação da agenda de política educacional. (idem, pg.161)

Entretanto, outra política educacional que vem ganhando corpo em âmbito nacional, estadual e até municipal, talvez subsidiariamente ajude a trazer o foco das novas políticas do setor para o aprendizado efetivo de todos os alunos: as sistemáticas avaliações de aprendizagem em larga escala. A farta disponibilidade de dados sobre eles, suas famílias e escolas facilita o surgimento de perguntas de pesquisa relacionadas aos seus interesses e contextos de aprendizagem. Andrews \& De Vries (2012) chamam atenção, entretanto, para os limites de seu papel: "os indicadores de desempenho devem ser encarados como instrumentos auxiliares das políticas educacionais e não como parâmetros a que as políticas devem se submeter irrefletidamente". A produção acadêmica mais recente vem superando os fossos entre as diferentes áreas de conhecimento, o que possivelmente potencialize o que cada uma tem a contribuir com o desenvolvimento da educação brasileira. 


\section{O contexto educacional brasileiro}

Para analisar o contexto de uma política pública implementada em âmbito nacional, como a descentralização, mesmo que do ponto de vista de apenas um estado, é necessário dar um passo atrás e compreender aquilo que afeta o ambiente específico da análise, mas que está localizado fora dele: i) a rápida expansão das matrículas nas últimas décadas, em um contexto de transição populacional; ii) a descentralização de alguns aspectos de sua governância, com autonomia relativa de municípios, escolas e professores; iii) a consolidação de sistemas de avaliação externa em larga escala e iv) a manutenção de elevadas desigualdades sociais nas oportunidades de aprendizagem oferecidas dos alunos.

\subsection{Descrição da estrutura da oferta de educação}

À época da Assembleia Constituinte, que negociou e redigiu a Constituição Federal atual, o Brasil era, dos pontos de vista social, econômico, político, previdenciário, educacional e de saúde, um país atrasado em relação, principalmente, aos da Europa e América do Norte mas também em relação a alguns vizinhos da América Latina. Assim, houve um grande esforço para incluir em seu texto provisões legais que pudessem contribuir para reverter os atrasos historicamente acumulados e declarar explicitamente princípios nos quais a sociedade brasileira pudesse se inspirar ${ }^{31}$. Com isto, em 1988, foi promulgada a Constituição apelidada de "cidadã", que abordou, quer tornando obrigatórios,

\footnotetext{
31 Constituição Federal de 1988 - Art. $3^{\circ}$ Constituem objetivos fundamentais da República Federativa do Brasil:

I - construir uma sociedade livre, justa e solidária;

II - garantir o desenvolvimento nacional;

III - erradicar a pobreza e a marginalização e reduzir as desigualdades sociais e regionais;

IV - promover o bem de todos, sem preconceitos de origem, raça, sexo, cor, idade e quaisquer outras formas de discriminação.
} 
reconhecidos ou expandidos, uma série de direitos, dantes negligenciados de maneiras e intensidades variadas.

A Constituição, para ser materializada, foi sucedida por centenas de leis e dezenas de emendas, que refletem não só a necessidade de concretização do que se aspirou na elaboração da Carta Magna atual, mas a própria evolução da

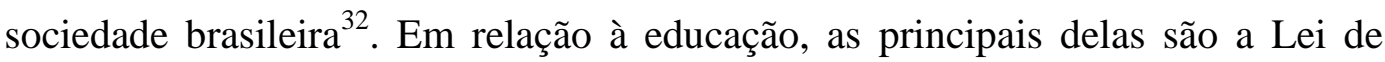
Diretrizes e Bases da Educação, de dezembro de 1996 (LDB/1996) e a Emenda Constitucional 59, de novembro de 2009 (EC59/2009). A primeira regula o funcionamento da educação brasileira e a segunda expande, de forma expressiva, a faixa etária de atendimento educacional obrigatório, adicionando 5 anos a mais de escolaridade compulsória (e, portanto, oferecida obrigatória e gratuitamente pelo Estado) aos 9 existentes, passando a ser dos 4 aos 17 anos.

Toda essa movimentação para expansão e garantia de direitos é excepcional e representa gigantesco esforço da sociedade brasileira para planejá-los, implementá-los, gerenciá-los e principalmente, custeá-los. Como os recursos financeiros e humanos são finitos, a disputa por ser reconhecido como prioridade se instala em praticamente todos os setores e nichos, que passam a ganhar (ou a perder) musculatura política em cada uma das etapas e oportunidades nas quais se enfrentam.

Em um país com as dimensões continentais (quinto no mundo ${ }^{33}$ ) e populacionais (quarto no mundo ${ }^{34}$ ) como o nosso, a garantia de direitos educacionais é, sem dúvida, um enorme desafio e reflete, hoje, o saldo das disputas por espaço e recursos entre os atores de nossa história.

32 Em Souza (2008), em uma revisão de todas as emendas constitucionais em 20 anos da CF de 1988 (grifo meu), a autora conclui: "que a Constituição de 1988 resultou do momento político marcado pelo objetivo de tornar crível e de legitimar o novo sistema democrático, dado que foi desenhada antes do fim da transição. Não por acaso, das 62 emendas, apenas duas mudaram as regras iniciais aplicáveis ao sistema político. No entanto, o desenho das políticas sociais e fiscais caminhou em direção oposta à da estabilidade. Isso porque, em virtude do objetivo legitimador da Constituição, negociações e barganhas referentes às políticas públicas e que encaminhassem alternativas para questões que afetavam as condições sociais da população e o desempenho macroeconômico do país foram marcadas por incertezas quanto a suas possibilidades. As emendas promulgadas a partir dos anos 1990 buscaram, então, desenhar novas políticas macroeconômicas, implementar um modelo econômico mais próximo do paradigma mundial vigente e pôr em prática mandamentos constitucionais relativos às políticas sociais (descentralização, participação, universalização) que não puderam ser negociados durante a transição.

33 Segundo os dados de 2010 do Banco Mundial, os cinco países de maior extensão territorial do mundo em Km2 são a Federação Russa, a China, os Estados Unidos da América, o Canadá e o Brasil, totalizando $40 \%$ do total mundial

34 Segundo os dados de 2011 do Banco Mundial, os cinco países mais populosos do mundo são a China, a Índia, os Estados Unidos da América, a Indonésia, o Brasil e o Paquistão, totalizando 50\% da população mundial 
Um exemplo do cenário de disputa pela definição de direitos, de parâmetros para seu cumprimento e de volume de recursos para sua efetivação é a tramitação no Legislativo, desde 2010, do segundo Plano Nacional de Educação (PNE), um conjunto de $21^{35}$ metas subdivididas em mais de duas centenas de estratégias que os governantes brasileiros, de todos os entes federados, devem comprir durante o decênio de sua validade, o que, em se materializando, daria ao sistema educacional brasileiro a seguinte configuração ${ }^{36}$ :

Em relação à cobertura:

$100 \%$ das crianças de 4 e 5 anos matriculadas na educação infantil

- $50 \%$ das crianças de 0-3 anos matriculadas em creches

- $100 \%$ das crianças de 6 a 14 anos matriculadas na educação fundamental, com $95 \%$ delas concluindo a etapa na idade correta

- $100 \%$ dos jovens de 15 a 17 anos matriculados no ensino médio, com $85 \%$ deles concluindo a etapa na idade certa $100 \%$ das crianças e jovens de 4 a 17 anos com necessidades especiais de atendimento educacional atendidas no sistema educacional

Em relação à qualidade:

- $100 \%$ das crianças alfabetizadas até os 6 anos de idade

- Oferta de educação integral37 a 100\% dos alunos da educação básica

- Ideb de 6,0 para o ciclo I do ensino fundamental, 5,5 para o ciclo II e 5,2 para o ensino médio e alcançar uma média de 473 pontos no Pisa

- População de 18 a 29 anos com escolaridade de 12 anos

- Analfabetismo absoluto erradicado

- Brasil classificado entre os 10 países com maior produção científica e com uma proporção de 4 doutores para cada 100 mil habitantes

Em relação à educação profissional e superior:

\footnotetext{
35 Até a data de elaboração deste documento

36 De acordo com o texto de dezembro de 2013 votado no Senado

37 Educação integral (não definida) é diferente de educação em tempo integral (com jornada igual ou superior a 7 horas diárias)
} 
$25 \%$ das matrículas de ensino médio integradas com o ensino profissionalizante

- $33 \%$ da população de 18 a 24 anos matriculada no ensino superior

- $75 \%$ dos docentes de ensino superior com título de mestre e $35 \%$ com título de doutor, com titulação anual de 60 mil mestres e 25 mil doutores

Em relação aos profissionais da educação:

- $100 \%$ dos docentes com formação na área de atuação

- $50 \%$ dos docentes com pós-graduação stricto ou lato senso

- Remuneração equivalente aos profissionais de mesmo nível de formação

- Planos de carreira para $100 \%$ das redes de educação

- Gestão democrática com participação da comunidade escolar e acadêmica

Em relação aos recursos disponíveis:

- $10 \%$ do Produto Interno Bruto aplicado no setor de educação

Mesmo com os avanços recentes e com a sociedade brasileira incorporando cada vez mais, como um valor em si, a educação formal de qualidade, com equidade, não se pode perder de vista que essa mudança de valores ainda é um processo em andamento e que há forças antagônicas, como mostrou Lerche (2007) em uma análise da evolução do tema educação nas constituições brasileiras, cujo balanço final é apresentado a seguir.

\begin{abstract}
As constituições expressam desejos de reforma da sociedade, apontando possibilidades sem assegurar garantias. Ao mesmo tempo, reforçam privilégios de grupos que fazem valer seus interesses junto ao Legislativo. O aprofundamento do tema permite apreciar o contraditório movimento da educação enquanto um valor que passa a incorporar-se aos anseios sociais sem, contudo, oferecer a cidadania plena. (LERCHE, 2007, Resumo)
\end{abstract}

O quadro abaixo mostra a denominação atual das etapas de atendimento educacional no Brasil, a faixa etária correspondente, o marco legal de obrigatoriedade quando cabível, a matrícula líquida mais atual (calculada com os dados do Censo de 2010) e a correspondente meta de atendimento prevista no Plano Nacional de Educação em tramitação. Ele é o balanço mais atualizado do incremento na legislação e não considera as indas e vindas de legislações prévias. 
Tabela 3: Etapas de ensino - idade correspondente, denominação, marco legal, matrícula líquida e meta PNE

\begin{tabular}{|c|c|c|c|c|c|c|}
\hline $\begin{array}{l}\text { Faixa etária } \\
\text { de referência } \\
\text { (em anos) }\end{array}$ & 0 a 3 & 4 a 5 & 6 a 10 & 11 a 14 & 15 a 17 & 18 a 24 \\
\hline $\begin{array}{l}\text { Denominação } \\
\text { atual }\end{array}$ & Creche & $\begin{array}{l}\text { Educação } \\
\text { infantil }\end{array}$ & $\begin{array}{l}\text { Ensino } \\
\text { fundament } \\
\text { al - } \\
\text { Anos } \\
\text { iniciais }\end{array}$ & $\begin{array}{l}\text { Ensino } \\
\text { fundament } \\
\text { al - } \\
\text { Anos finais }\end{array}$ & $\begin{array}{l}\text { Ensino } \\
\text { médio }\end{array}$ & $\begin{array}{l}\text { Ensino } \\
\text { superior }\end{array}$ \\
\hline $\begin{array}{l}\text { Marco legal de } \\
\text { obrigatoriedad } \\
\mathrm{e} \quad \mathrm{de} \\
\text { atendimento } \\
\text { pelo setor } \\
\text { público }\end{array}$ & -- & $\begin{array}{l}\text { EC 59 de } \\
2009^{38}\end{array}$ & $\begin{array}{l}\mathrm{CF}^{39} \text { de } \\
1946 \\
\mathrm{LDB}^{40} \text { de } \\
1971 \\
\mathrm{Lei}^{41} \\
11.274 / 200 \\
6\end{array}$ & $\begin{array}{ll}\mathrm{CF}^{42} & \mathrm{de} \\
1967 & \end{array}$ & $\begin{array}{ll}\text { EC } & \text { de } \\
2009 & \end{array}$ & -- \\
\hline $\begin{array}{l}\text { Situação atual } \\
-\quad \text { matrícula }^{4} \text { líquida }^{43}{ }^{4}\end{array}$ & $23,5 \%$ & $\begin{array}{l}87,3 \% \text { aos } \\
5 \text { anos }\end{array}$ & $\begin{array}{l}95,0 \% \text { aos } \\
6 \text { anos e } \\
63,5 \% \text { aos } \\
10\end{array}$ & $\begin{array}{l}62,8 \% \text { aos } \\
11 \text { anos e } \\
48,3 \% \text { aos } \\
14\end{array}$ & $\begin{array}{l}47,5 \% \text { aos } \\
15 \text { anos e } \\
27,6 \% \text { aos } \\
17\end{array}$ & $\begin{array}{l}10,5 \% \text { aos } \\
18 \text { anos e } \\
11,3 \% \text { aos } \\
24\end{array}$ \\
\hline $\begin{array}{l}\text { Meta prevista } \\
\text { no novo PNE, } \\
\text { com } \\
\text { cumprimento } \\
\text { dentro de sua } \\
\text { vigência }\end{array}$ & $\begin{array}{l}\text { Atender } \\
50 \% \text { desta } \\
\text { faixa até o } \\
\text { fim do } \\
\text { PNE }\end{array}$ & $\begin{array}{l}\text { Universali } \\
\text { zar até } \\
2016\end{array}$ & \multicolumn{2}{|c|}{$\begin{array}{l}\text { Universalizar até } 2016 \text {, } \\
\text { com conclusão de } 95 \% \\
\text { na idade adequada até o } \\
\text { fim do PNE }\end{array}$} & \begin{tabular}{l}
\multicolumn{2}{l}{ Universali } \\
zar até \\
2016, \\
alcançar \\
taxa \\
líquida de \\
$85 \%$ até \\
o fim do \\
PNE
\end{tabular} & $\begin{array}{l}\text { Alcançar } \\
\text { taxa } \\
\text { líquida de } \\
33 \% \text {, sem } \\
\text { definição } \\
\text { de prazo }\end{array}$ \\
\hline
\end{tabular}

Resultado da base legal renovada e do saldo das disputas históricas, em 2011, o Brasil tinha sob sua responsabilidade a educação formal escolar e universitária de 52,4 milhões de alunos, distribuídos entre as dependências administrativas conforme tabela a seguir:

Tabela 4: Distribuição das matrículas por dependência administrativa e etapa Brasil (2011)

38 Emenda Constitucional n59/2009 ao artigo $208^{\circ}$ da Constituição Federal de 1988, a ser cumprida até 2016I - educação básica obrigatória e gratuita dos 4 (quatro) aos 17 (dezessete) anos de idade, assegurada inclusive sua oferta gratuita para todos os que a ela não tiveram acesso na idade própria 39 Constituição Federal de 1946, artigo $168^{\circ}$, inciso I, apenas menciona a obrigatoriedade do ensino primário, sem fazer menção à faixa etária

$40 \mathrm{Na}$ Lei de Diretrizes e Bases de 1971 (5692/71), o artigo $20^{\circ}$ estabelecia como obrigatório o ensino de 7 a 14 anos e o artigo $19^{\circ}$ estabelecia que a idade mínima de entrada no ensino obrigatório era de 7 anos

41 Lei 11.274 de 2006 alterou a redação da Lei de Diretrizes e Bases de 1996 (9394/96), estabelecendo o ensino obrigatório de 9 anos, com início aos 6 anos de idade

42 Constituição Federal de 1967, artigo $168^{\circ}$ : torna obrigatório o ensino de 7 a 14 anos, sendo apenas o primário obrigatoriamente gratuito nos estabelecmentos oficiais, para além do primário poderiam ser concedidas bolsas para quem comprovasse carência e aproveitamento

43 Porcentual da população em determinada faixa etária que se encontra matriculada no nível de ensino adequado à sua idade

44 Fonte: IBGE, Censo 2010. http://www.sidra.ibge.gov.br/bda/tabela/listabl.asp?z=cd\&o=30\&i=P\&c=1973. Cálculos autora 


\begin{tabular}{|c|c|c|c|c|c|c|}
\hline \multicolumn{7}{|c|}{ Brasil 2011} \\
\hline \multicolumn{2}{|l|}{ Etapas } & Total & Federal & Estadual & Municipal & Privada \\
\hline Creche & & 2.298 .707 & 1.359 & 8.114 & 1.461 .034 & 828.200 \\
\hline Educação infantil & & 4.681 .345 & 1.193 & 56.538 & 3.493 .307 & 1.130 .307 \\
\hline \multirow{2}{*}{ Ensino fundamental } & Anos iniciais & 16.360 .770 & 7.084 & 2.872 .378 & 11.138 .287 & 2.343 .021 \\
\hline & Anos finais & 13.997 .870 & 18.012 & 6.832 .636 & 5.387 .782 & 1.759 .440 \\
\hline Ensino médio total & & 8.400 .689 & 114.939 & 7.182 .888 & 80.833 & 1.022 .029 \\
\hline Educação profissional & & 993.187 & 97.610 & 313.687 & 22.335 & 559.555 \\
\hline \multicolumn{2}{|c|}{ Total educação básica } & 46.732 .568 & 240.197 & 17.266 .241 & 21.583.578 & 7.642 .552 \\
\hline & $\%$ & $100,0 \%$ & $0,5 \%$ & $36,9 \%$ & $46,2 \%$ & $16,4 \%$ \\
\hline Ensino superior presen & & 5.746 .762 & 927.086 & 548.202 & 120.103 & 4.151 .371 \\
\hline & Total geral & 52.479.330 & 1.167 .283 & 17.814 .443 & 21.703.681 & 11.793 .923 \\
\hline & $\%$ & $100,0 \%$ & $2,2 \%$ & $33,9 \%$ & $41,4 \%$ & $22,5 \%$ \\
\hline
\end{tabular}

Fonte: INEP, Sinopse estatística da educação básica 2011 e Sinopse da educação superior graduação 2011

Da mesma forma, para o Estado de São Paulo, 11,4 milhões de alunos (23,8\% do total brasileiro) foram atendidos em 2011 nas etapas da educação básica regular e no ensino superior presencial, segundo a distribuição a seguir.

Tabela 5: Distribuição das matrículas por dependência administrativa e etapa -São Paulo (2011)

\begin{tabular}{|c|c|c|c|c|c|c|}
\hline \multicolumn{7}{|c|}{ São Paulo 2011} \\
\hline \multicolumn{2}{|l|}{ Etapas } & \multirow{2}{*}{\begin{tabular}{|l|} 
Total \\
761.843 \\
\end{tabular}} & \multirow{2}{*}{$\begin{array}{r}\text { Federal } \\
235 \\
\end{array}$} & \multirow{2}{*}{$\begin{array}{r}\text { Estadual } \\
894 \\
\end{array}$} & \multirow{2}{*}{$\begin{array}{r}\text { Municipal } \\
402.265 \\
\end{array}$} & \multirow{2}{*}{\begin{tabular}{|c|} 
Privada \\
358.449 \\
\end{tabular}} \\
\hline Creche & & & & & & \\
\hline Educação infantil & & 991.085 & 130 & 401 & 795.745 & 194.809 \\
\hline \multirow{2}{*}{ Ensino fundamental } & Anos iniciais & 2.963 .506 & 216 & 714.133 & 1.727 .436 & 521.721 \\
\hline & Anos finais & 2.924 .216 & - & 1.849 .193 & 632.389 & 442.634 \\
\hline Ensino médio total & & 1.872 .887 & 1.483 & 1.590 .929 & 22.957 & 257.518 \\
\hline Educação profissional & & 343.902 & 3.759 & 146.036 & 14.911 & 179.196 \\
\hline \multicolumn{2}{|c|}{ Total educação básica } & 9.857.439 & 5.823 & 4.301 .586 & 3.595.703 & 1.954 .327 \\
\hline & $\%$ & $100,0 \%$ & $0,1 \%$ & $43,6 \%$ & $36,5 \%$ & $19,8 \%$ \\
\hline \multicolumn{2}{|c|}{ Ensino superior presencial } & 1.542 .415 & 30.114 & 163.103 & 38.043 & 1.311 .155 \\
\hline & Total geral & 11.399.854 & 35.937 & 4.464.689 & 3.633 .746 & 3.265 .482 \\
\hline & $\%$ & $100,0 \%$ & $0,3 \%$ & $39,2 \%$ & $31,9 \%$ & $28,6 \%$ \\
\hline
\end{tabular}

Fonte: INEP, Sinopse estatística da educação básica 2011 e Sinopse da educação superior graduação 2011

A comparação entre as duas tabelas revela algumas proporções interessantes. As mais relevantes para este estudo são: a proporção de matrículas atendida pelos municípios no conjunto das etapas da educação básica é bem menor em São Paulo $(36,5 \%)$ que no conjunto dos outros estados $(46,2 \%)$, o que é ainda mais discrepante nas duas etapas do ensino fundamental, nas quais o volume de matrículas dos dois seguimentos se equipara entre o estado e seus municípios, enquanto no restante do Brasil, o volume de matrículas cobertas pelos municípios é $70 \%$ maior que o dos estados.

Uma análise detalhada da proporção de matrículas estaduais e municipais (as particulares, que fazem parte do total, não estão apresentadas) por Regiões do 
Brasil e estados da Região Sudeste, apresentada no gráfico a seguir, mostra que São Paulo está entre os estados menos municipalizados do país.

Gráfico 1: Distribuição das matrículas estaduais e municipais, Brasil, Regiões e estados da Região Sudeste (2011)

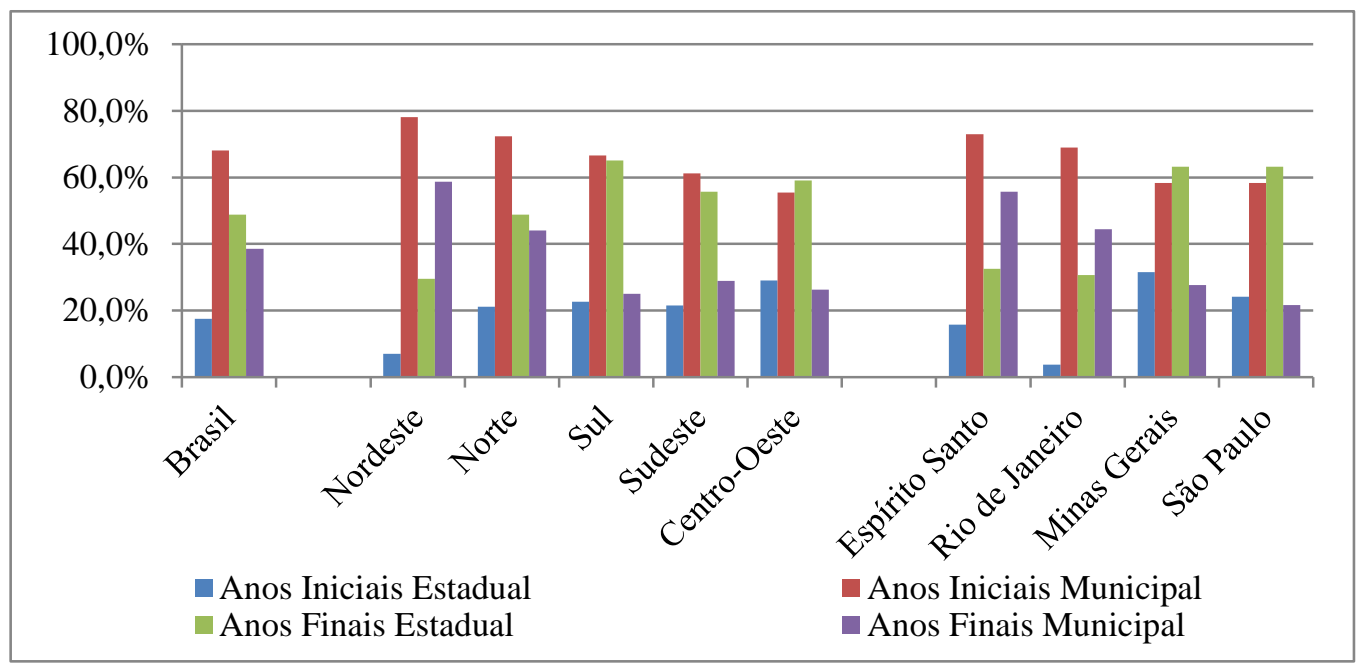

Fonte: INEP, Sinopse Estatística da Educação Básica 2011. Tabulação própria.

Isso se explica porque apesar de a descentralização de políticas sociais, em particular as de educação, ter sido uma tendência no Brasil pós democratização, em contraponto à centralização em nível federal dos anos de governo militar, ela vem sendo induzida e regulamentada a partir do centro em direção à periferia, onde os contextos locais são muito diferentes. É um processo deliberado, que depende de clara decisão política, capacidade burocrática para formular programas e normas alinhados com a intencionalidade da decisão e da disponibilidade de recursos humanos e materiais para fomentar a adesão dos governos locais (ARRETCHE, 2011). Assim, no que toca a descentralização das matrículas do ensino fundamental, cada estado brasileiro tem a sua própria história, a depender, principalmente do interesse do executivo em abrir mão do controle das matrículas e, no contexto pós Fundef, das receitas a elas atreladas (GOMES, 2008). Segundo Abreu, (2003) havia dois grandes grupos em relação ao nível de municipalização logo antes do advento do Fundef, o qual efetivamente estimulou a busca pela matrícula por parte dos municípios: os estados no Nordeste, que já tinham transferido a maior parte das matrículas para os municípios com menor poder de barganha (que assumiram as matrículas sem grandes estímulos ou compensações) e os da Região Sudeste, cujas localidades 
tinham mais condições de se opor à transferência. São Paulo encontra-se no segundo grupo.

Ainda recorrendo a Gomes (2008) o governo estadual de São Paulo lançou mão da restruturação da rede de escolas, dividindo o atendimento dos anos iniciais e finais do ensino fundamental em estabelecimentos distintos no ano de 1995 para poder, ao mesmo tempo, diminuir despesas com pessoal inativo da Secretaria e compartilhar recursos do Fundef com a expansão do ensino médio que compartilhava os prédios com os anos finais do ensino fundamental. Mesmo com todo o esforço empreendido, o estado ainda é dos que conta com maior nível de matrículas sob seu controle.

\subsection{Expansão rápida e recente das matrículas: uma corrida contra o tempo}

A população brasileira está passando por um ajuste de perfil etário sem precedentes, que tem sido descrito como uma bifurcação crucial de sua história econômica e social rumo ao futuro. A discussão que se tem feito é se o chamado "bônus demográfico" seria a grande oportunidade para o país encontrar seu futuro brilhante, ou mais um componente de uma armadilha social e econômica crônica e incurável. O relatório do Banco Mundial (2011) "Envelhecendo em um Brasil mais velho: implicações do envelhecimento populacional sobre crescimento econômico, redução da pobreza, finanças públicas e prestação de serviços (Sumário)" resume o fenômeno da seguinte forma:

As rápidas mudanças demográficas em curso no Brasil representam antes de tudo uma enorme oportunidade para impulsionar o crescimento e o desenvolvimento social e econômico do País. O Brasil passa, por um curto período, o chamado "bônus demográfico", único na história de cada nação, quando a força de trabalho é muito maior do que a população dependente $^{45}$. Este é um ponto de inflexão que no Brasil deve

450 Brasil está atualmente passando pelo chamado "bônus demográfico", que representa o período na transição demográfica de um país quando a proporção de pessoas em idade ativa é alta. Esse período é caracterizado por uma menor razão de dependência (relação entre o número de dependentes e pessoas em idade ativa). A razão de dependência, que tem declinado desde 1965, atingirá seu valor mínimo em 2020 e então começará a subir. (Banco Mundial, 2011) 
durar apenas até 2020, mas cujos impactos durarão indefinidamente.

Assim, é impossível exagerar a importância do momento. As escolhas do País em termos de educação, saúde e previdência nesta fase determinarão a capacidade do País para investir adequadamente nos seus jovens, dar uma vida digna e longa aos seus idosos, e continuar crescendo, oferecendo serviços de qualidade cada vez maior à população, e competindo internacionalmente - em suma, assumindo cada vez mais a condição de país desenvolvido.(BANCO MUNDIAL, 2011, Prefácio)

Essa aparente janela de oportunidade tem uma característica particular no caso brasileiro, que é sua extrema fulgacidade. O mesmo relatório do Banco Mundial faz a seguinte comparação:

A velocidade do envelhecimento populacional no Brasil será significativamente maior do que ocorreu nas sociedades mais desenvolvidas no século passado. Por exemplo, foi necessário mais de um século para que a França visse sua população com idade igual ou superior a 65 anos aumentar de $7 \%$ para $14 \%$ do total. Em contraste, essa mesma variação demográfica ocorrerá nas próximas duas décadas (entre 2011 e 2031) no Brasil. A população idosa irá mais do que triplicar nas próximas quatro décadas, de menos de 20 milhões em 2010 para aproximadamente 65 milhões em 2050.

A população idosa aumentará de $11 \%$ da população em idade ativa em 2005 para $49 \%$ em 2050, enquanto que a população em idade escolar diminuirá de $50 \%$ para $29 \%$ no mesmo período. (BANCO MUNDIAL, 2011, pg. 10)

A tabela a seguir apresenta a evolução das faixas etárias prioritárias para atendimento educacional no Brasil nas últimas quatro décadas. De fato, nota-se uma expansão inicial seguida de retração, com as projeções populacionais já mostrando a aceleração desse processo.

Tabela 6: Evolução da população de 1980 a 2010 e projeção para 2020, por faixas etárias selecionadas - Brasil

\begin{tabular}{lrrrr}
\hline \multirow{2}{*}{ Anos } & \multicolumn{4}{c}{ Estimativas e *Censos Populacionais por Faixa Etária } \\
& Brasil 1980 - 2020 \\
\cline { 2 - 5 } & 0 a 6 anos & 7 a 14 anos & 15 a 17 anos & 18 a 24 anos \\
\hline $\mathbf{1 9 8 0}$ & 22.376 .625 & 22.963 .225 & 8.302 .606 & 11.513 .220 \\
\hline $\mathbf{1 9 9 0}$ & 24.967 .725 & 26.822 .211 & 8.862 .390 & 13.554 .043 \\
\hline $\mathbf{2 0 0 0 *}$ & 23.699 .857 & 27.124 .709 & 10.702 .499 & 23.378 .831 \\
\hline $\mathbf{2 0 1 0 *}$ & 22.075 .516 & 26.309 .729 & 10.357 .874 & 23.878 .190 \\
\hline Var \% 1980-2010 & $-1 \%$ & $15 \%$ & $25 \%$ & $107 \%$ \\
\hline $\mathbf{2 0 2 0}$ (projeção) & 17.983 .808 & 23.587 .526 & 10.101 .305 & ND \\
\hline
\end{tabular}


Var \% 2010-2020 $-19 \%$ $-10 \%$ $-2 \%$ ND

Nota: o IBGE não apresenta projeção populacional para o recorte 18 a 24 anos, mas a Fundação SEADE o faz para o Estado de São Paulo (abaixo)

Fonte: IBGE. Estimativas Populacionais por Ano, Censo 2000 e Censo 2010. Tabulação e cálculos próprios

Para essas faixas etárias, o fenômeno populacional é o mesmo no Estado de São Paulo, com o pico de 16,9 milhões já tendo sido atingido no ano 2000 . O gráfico a seguir apresenta a evolução destes grupos de 1980 a 2013, com a projeção para 2020.

Gráfico 2: Evolução da população de 1980 a 2013, com projeção para 2020, por faixas etárias selecionadas - São Paulo

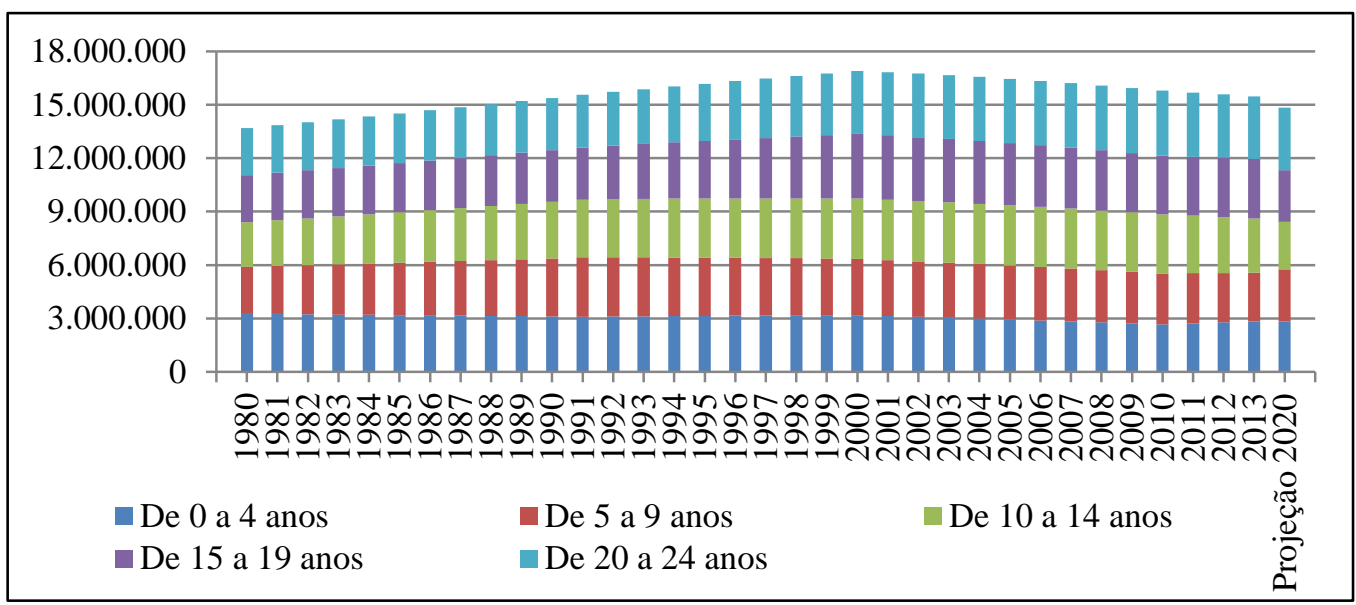

Fonte: Fundação Seade. Tabulação própria.

Em relação às matrículas também houve um crescimento muito acelerado, mas ainda há etapas que vão continuar se expandindo antes de começarem a declinar. As tabelas a seguir mostram a evolução das matrículas por etapa de ensino nas últimas três décadas no Brasil.

Tabela 7 : Evolução das matrículas totais de 1980 a 2010 e projeção de acordo com o Plano Nacional de Educação, por etapa de ensino - Brasil

\begin{tabular}{|r|r|r|r|r|}
\hline \multicolumn{5}{|c|}{ Brasil - Matriculas totais (inclui particular) } \\
\hline Anos & \multicolumn{2}{c|}{$\begin{array}{c}\text { Ensino } \\
\text { Fundamental } \\
(\mathbf{8} \text { anos) }\end{array}$} & Ensino médio & $\begin{array}{c}\text { Ensino } \\
\text { superior }\end{array}$ \\
\hline $\mathbf{1 9 8 0}$ & 1.335 .317 & 22.148 .809 & 2.823 .544 & 1.377 .286 \\
\hline $\mathbf{1 9 9 1}$ & 3.605 .511 & 28.948 .266 & 3.725 .133 & 1.540 .080 \\
\hline $\mathbf{2 0 0 0}$ & 4.421 .332 & 35.717 .948 & 8.192 .948 & 2.694 .245 \\
\hline $\mathbf{2 0 1 0}$ & 6.756 .698 & 31.005 .341 & 8.357 .675 & 5.449 .120 \\
\hline Var \% 1980 - 2010 & $406 \%$ & $40 \%$ & $196 \%$ & $296 \%$ \\
\hline $\mathbf{2 0 2 0}$ (projeção PNE)* & 6.444 .198 & 23.587 .526 & 10.101 .305 & ND \\
\hline Var \% 2010 - 2020 & $-5 \%$ & $-24 \%$ & $21 \%$ & ND \\
\hline
\end{tabular}

Considerando apenas matrículas líquidas para fins de cálculo.

Fonte: IBGE, Estatísticas do século XX. Tabulação e cálculos próprios. 
Nota: O IBGE não calcula a projeção populacional para o recorte de 18 a 24 anos, mas a Fundação Seade faz a projeção para o Estado de São Paulo (abaixo).

Em São Paulo, aparentemente, o processo está adiantado e a retração nas matrículas já pode começar a aparecer nos próximos anos.

Tabela 8:São Paulo - Evolução das matrículas totais de 1980 a 2010 e projeção de acordo com o Plano Nacional de Educação, por etapa de ensino

\begin{tabular}{|r|r|r|r|r|}
\hline \multicolumn{5}{|c|}{ São Paulo - Matriculas totais (inclui particular) } \\
\hline Anos & \multicolumn{2}{c|}{$\begin{array}{c}\text { Ensino } \\
\text { Fundamental } \\
(\mathbf{8} \text { anos) }\end{array}$} & Ensino médio & $\begin{array}{c}\text { Ensino } \\
\text { superior }\end{array}$ \\
\hline $\mathbf{1 9 8 0}$ & 389.448 & 4.343 .567 & 730.665 & 449.556 \\
\hline $\mathbf{1 9 9 1}$ & 790.846 & 6.165 .157 & 1.071 .918 & 497.294 \\
\hline $\mathbf{2 0 0 0}$ & 1.130 .293 & 6.225 .204 & 2.079 .141 & 818.304 \\
\hline $\mathbf{2 0 1 0}$ & 1.695 .269 & 5.985 .884 & 1.839 .535 & 1.474 .516 \\
\hline Var \% 1980 - 2010 & $335 \%$ & $38 \%$ & $152 \%$ & $228 \%$ \\
\hline $\mathbf{2 0 2 0}$ (projeção PNE*) & 1.722 .294 & 4.992 .783 & 1.741 .843 & 1.155 .695 \\
\hline Var \% 2010 - 2020 & $2 \%$ & $-17 \%$ & $-5 \%$ & $-22 \%$ \\
\hline Fon & & & & \\
\hline
\end{tabular}

Fontes:

De 1990 a 1990 - IBGE, Estatísticas do Século XX. http://seculoxx.ibge.gov.br/populacionaissociais-politicas-e-culturais/busca-por-temas/educacao. Acesso em 28/8/2013

De 2000 a 2010. INEP - Sinopse Estatística da Educação Básica.

* Projeção de atendimento: cálculo próprio com base na projeção de população por faixa etária do IBGE e nas metas do PNE 2010. Tabulação e cálculos próprios.

Entretanto, ao analisar a evolução comparativa da matrícula ${ }^{46}$ no ensino secundário entre os países do G-20 e do grupo América do Sul + México, nota-se que, na década de 1970 o Brasil estava atrasado não só em relação aos que hoje são considerados industrializados, mas até a alguns vizinhos da América do Sul, como Peru, Uruguai, Argentina e Chile, México, Equador e Venezuela. Ou seja, a largada da educação pode já ter sido dada tarde demais, como sugere o relatório do Banco Mundial sobre o bônus demográfico. 
Gráfico 3: Evolução da matrícula bruta no ensino secundário (1970-19902010*) - países do G-20 + América do Sul e México

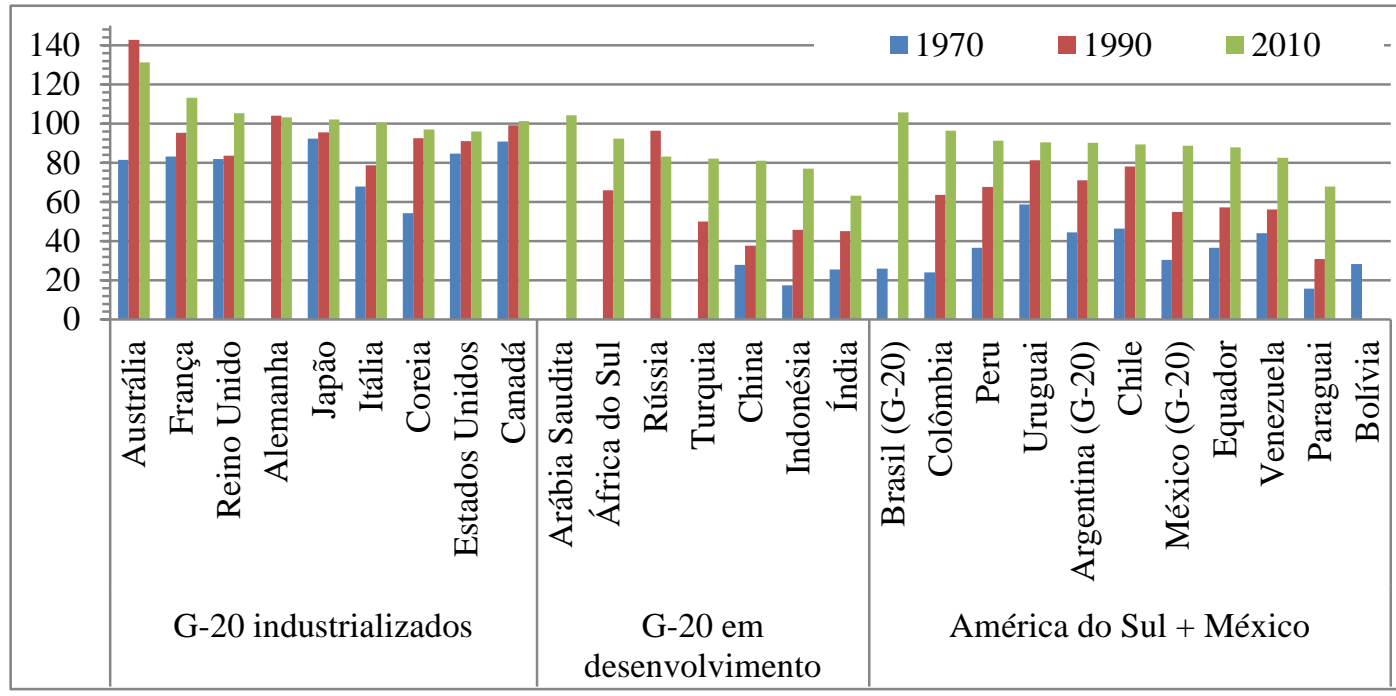

Fonte: World Development Indicators, http://databank.worldbank.org/data/home.aspx Nota: * os dados que não estivessem disponíveis nos pontos na linha do tempo foram inseridos se houvesse um lapso de até 5 anos entre os dados disponíveis. O Brasil não tem dados para 1990 ou lapso equivalente

Assim, mesmo experimentando excepcional crescimento nas matrículas, é possível que a dúvida pessimista sobre a possibilidade de se aproveitar a janela populacional seja pertinente, porque a legislação que garatiu acesso universal à educação primária e secundária é muito recente e, para além dos aspectos formais que obrigam as famílias a matricular seus filhos nas escolas e as autoridades a lhes fornecer vagas, há práticas e crenças sociais que podem dificultar o processo de aumento de escolarização de uma nação. Se consideramos as constituições um reflexo de sua época, como propôs Lerche (2007), o próprio texto da Carta Magna de 1967 deixa transparecer a dúvida da sociedade brasileira tinha, à época, quanto à capacidade de todos os brasileiros seguirem na escola para além do ensino primário:

Art 168 - A educação é direito de todos e será dada no lar e na escola; assegurada a igualdade de oportunidade, deve inspirarse no princípio da unidade nacional e nos ideais de liberdade e de solidariedade humana.

$[\ldots]$

$\S 3^{0}$ - A legislação do ensino adotará os seguintes princípios e normas:

$[\ldots]$ 
II - o ensino dos sete aos quatorze anos é obrigatório para todos e gratuito nos estabelecimentos primários oficiais;

III - o ensino oficial ulterior ao primário será, igualmente, gratuito para quantos, demonstrando efetivo aproveitamento, provarem falta ou insuficiência de recursos. Sempre que possível, o Poder Público substituirá o regime de gratuidade pelo de concessão de bolsas de estudo, exigido o posterior reembolso no caso de ensino de grau superior (BRASIL, 1967)

O estado de espírito dos Constituintes em 1987 era obviamente diferente daquele dos seus antecessores de 1967, assim como seu contexto político e histórico, o que levou-os a produzir um texto constitucional profundamente modificado, inclusive em seus princípios fundamentais. Mas é possível que características arraigadas na própria sociedade brasileira, tenham permanecido válidas depois de 1988 e até os dias de hoje e que, refletidas no ambiente educacional, continuem a emperrar a evolução da nossa educação.

Portanto, apesar da existência de uma legislação vigente que estabeleça parâmetros mais ambiciosos para a educação brasileira, a nossa sociedade ainda está se adaptando a eles. Um exemplo disso é que o impressionante crescimento das matrículas no período de 1970 a 2010, por ter sido feito com atraso em relação ao provimento de educação em massa para além da etapa primária, pode ter impactado na capacidade do país em alcançar níveis de qualidade mais rapidamente, uma vez que não tenha sido possível preparar professores com formação adequada em quantidade suficiente. Este desafio é apontado por Gatti e Barretto (2009):

Com as pressões populares, com as demandas da expansão industrial e do capital, os investimentos públicos no ensino fundamental começam a crescer e a demanda por professores também aumenta. O suprimento de docentes nas escolas caminha por meio de várias adaptações: expansão das escolas normais em nível médio, cursos rápidos de suprimento formativo de docentes, complementação de formações de origens diversas, autorizações especiais para exercício do magistério a não licenciados, admissão de professores leigos etc.

Assim, a formação de professores no país ainda sofre os impactos do crescimento efetivo tão recente e rápido das redes públicas e privadas de ensino fundamental, e das improvisações que foram necessárias para que as escolas funcionassem. 
Crescimento recente em face da história da escolarização em outros países, e crescimento vertiginoso em pouco mais de 40 anos, a considerar os dados da demografia educacional no Brasil. Esse crescimento do sistema escolar foi sem dúvida um mérito, provindo de grande esforço social, político e de administração, porém é chegado o momento de se conseguir que esse sistema tenha melhor qualidade em seus processos de gestão, nas atuações dos profissionais e nas aprendizagens pelas quais responde. Um dos aspectos a se considerar nessa direção, entre outros, é a formação dos professores, sua carreira e perspectivas profissionais. (GATTI \& BARRETTO, 2009, pgs. 11-12)

Como mostram as autoras, a constatação do atraso só fica evidente em comparações com outros países, o que tem sido facilitado por avaliações internacionais sistemáticas, sendo a mais disseminada no Brasil o Programa Internacional de Avaliação de Estudantes (Pisa), de cujas edições trienais o Brasil participa desde 2000. De acordo com a metodologia do exame, para participar, o aluno deve ter entre 15 anos e três meses e 16 anos e dois meses ${ }^{47}$, matriculado na sexta série/sétimo ano ou além. Devido às altas taxas de distorção idade-série e à evasão/abandono, um grande contingente da coorte em questão acaba excluída dos exames em muitos países.

Embora, no caso do Brasil, observe-se um decréscimo sensível da dimensão desse grupo excluído nas edições do Pisa desde 2000, de 47\% em 2000 para $19 \%$ em $2009^{48}$, uma comparação entre países mostra os alunos brasileiros com atraso em relação aos países desenvolvidos e aos vizinhos da América do Sul, só apresentando uma distribuição da coorte de 15/16 anos melhor que a do México e a da Colômbia (ver Anexo 1).

Essa dificuldade em se adaptar a novos tempos, a uma nova cultura escolar e, principalmente a buscar a excelência e a equidade a partir da escola, determinando os fundamentos da lógica da educação brasileira, é descrita por

47 PISA assesses students who were aged between 15 years and 3 (complete) months and 16 years and 2 (complete) months at the beginning of the assessment period, plus or minus a 1 month allowable variation, and who were enrolled in an educational institution with Grade 7 or higher, regardless of the grade levels or type of institution in which they were enrolled, and regardless of whether they were in full-time or part-time education. PISA 2009 48 Cálculo baseado nas informações sobre população-alvo do Pisa em 2000, 2003, 2006 e 2009. Tabela no Anexo. 
Costa Ribeiro em 1991 no artigo em que cunhou a expressão "Pedagogia da Repetência":

\begin{abstract}
Mesmo correndo o risco de ser simplista e reducionista, achamos que a prática da repetência está na própria origem da escola brasileira. $\mathrm{O}$ mesmo modelo de ensino da elite, onde o papel do professor era muito mais de preceptor da educação orientada pela família do que auto-suficiente, do ponto de vista de ensino -aprendizagem. É como se a escola tivesse apenas um papel de administradora da educação formal, que seria realizada em casa pela família.
\end{abstract}

As análises antropológicas até hoje realizadas mostram claramente na cultura do sistema a imputação do fracasso escolar, ora aos próprios alunos, ora a seus pais, ora ao sistema sociopolítico, raramente aos professores, sua formação ou à organização escolar.

Parece que a prática da repetência está contida na pedagogia do sistema como um todo. É como se fizesse parte integral da pedagogia, aceita por todos os agentes do processo de forma natural. A persistência desta prática e da proporção desta taxa nos induz a pensar numa verdeira metodologia pedagógica que subsiste no sistema, apesar de todos os esforços no sentido de uiversalidzar a educação básica no Brasil.

É sintomático perceber que os esforço das famílias brasileiras em manter seus filhos na escola não se traduz numa escolarização mais competente. Tudo leva a crer que nunca houve uma real função educadora de forma auto-suficente na escola. Hoje, a escola é um restaurante, um ambulatório médico, uma creche ou um depósito de crianças. Raramente encontramos uma escola que pretenda que seu processo de ensino-aprendizagem formal se esgote intramuros independente da situação da criança. (COSTA RIBEIRO, 1991, pg: 17-18)

De fato, o Brasil tem uma das taxas de distorção idade-série maiores do mundo (Unesco, 2012). No gráfico a seguir apresentam-se dados recentes de distorção idade-série (2012), detalhados para as regiões geográficas do Brasil e para os estados da região Sudeste. Percebe-se a persistência da "pedagogia da repetência" ainda neste início de séc. XXI, pois a proporção de alunos com idade acima da série correspondente aumenta com o percurso escolar e mantém-se alta mesmo nas redes privadas, que contam com um corpo discente diferente daquele das escolas públicas. Ao mesmo tempo que vemos o Estado de São Paulo com números menos ruins que os do resto do país, vemos que o estado do Rio de 
Janeiro está mais alinhado com a Região Nordeste que com as Regiões Sul e Sudeste.

Gráfico 4: Taxa de distorção idade-série (\%) Brasil, Regiões e estados do Sudeste (2012)

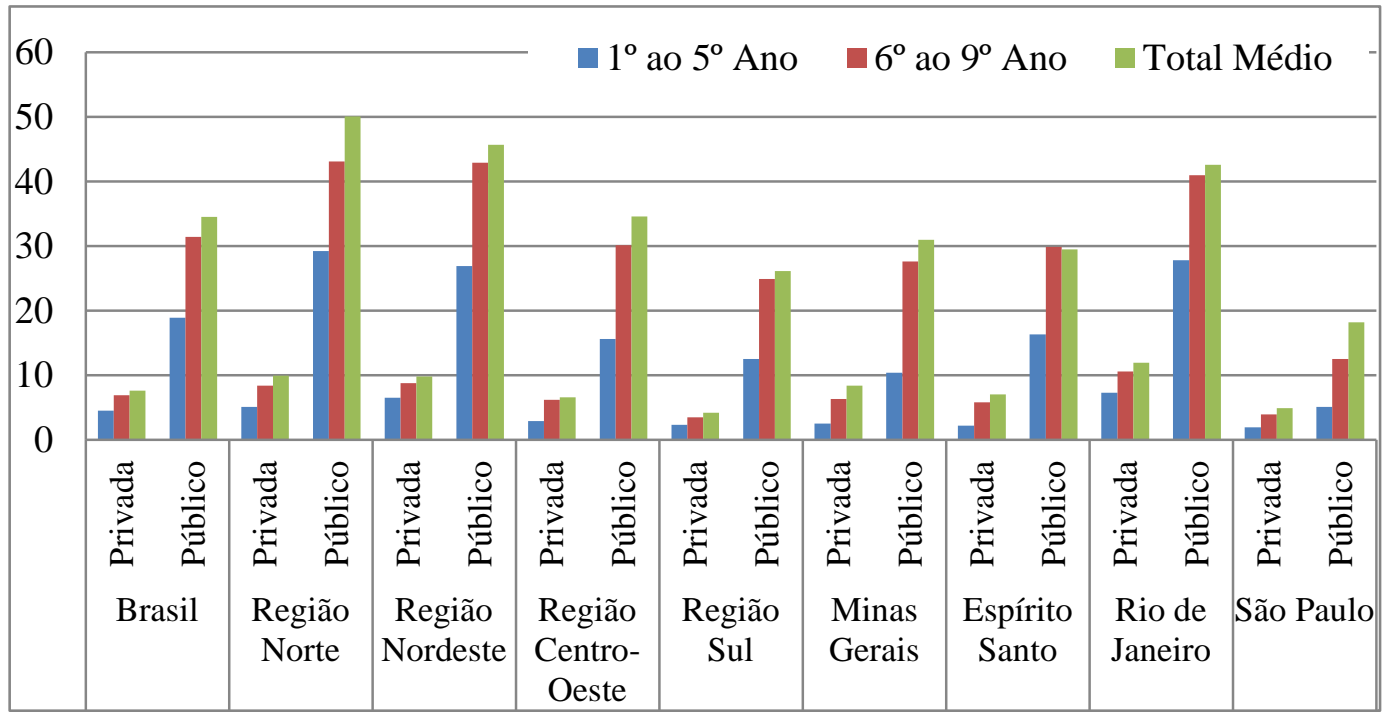

Fonte: INEP, Indicadores Educacionais. http://portal.inep.gov.br/indicadores-educacionais/. Tabulação própria.

Uma visão também pessimista dos obstáculos aos avanços educacionais brasileiros é apresentada por Plank (1996), que argumenta que as dificuldades brasileiras com a educação e bem-estar social não estão associadas ao fracasso das políticas, mas ao descaso dos políticos e responsáveis quanto ao sucesso dos sistemas de educação, buscando acima de tudo atender seus próprios interesses individuais e os de seus aliados, mesmo que declarem publicamente e nas normas que ajudam a criar, que seus objetivos perseguidos são os mais nobres. Além disso, as disputas privadas por recursos materiais, empregos, poder e pelos benefícios políticos de sua distribuição é o que rege a gestão dos sistemas (pgs: 11-13)

De fato, não faltaram nem diagnósticos, nem clamores recorrentes pela expansão e melhoria das condições educacionais brasileiras desde idos tempos, como os pareceres de Rui Barbosa nos anos de 1880 (em LOURENÇO FILHO, 2001) ou nos Manifestos Dos Pioneiros Da Educação Nova de 1932 e o Dos Educadores de 1959 (AZEVEDO et al., 2010)

Resumindo: de acordo com as explicações apresentadas, o atraso educacional brasileiro parece estar longe de ser ultrapassado. A constituição pode 
ter mudado em relação à extensão da obrigatoriedade escolar, mas há possívelmente, outras peças fundamentais do arcabouço legal que rege a educação no Brasil que ainda estejam sendo disputadas por grupos de interesse. A tramitação do novo Plano Nacional da Educação pode ser incluída no rol das disputas históricas por espaço na educação, onde o que está em jogo não necessariamente é o que atende aos direitos dos alunos e aos anseios da nação (SENADO FEDERAL, 2013).

Mesmo que o corpo legal já fosse arejado e ambicioso, parece que a sociedade e as comunidades escolares precisam de um tempo longo para mudar de hábitos e de práticas que materializem o espírito novo das leis. E, se a descrição do cenário feita por Plank não estiver muito longe da realidade, até o que é declarado como prioridade na legislação ainda tem que sobreviver, na regulamentação e na implementação, ao embate de interesses mais urgentes e individuais de quem estiver no comando dos Ministérios, das redes escolares públicas e das escolas públicas e privadas, além das próprias dificuldades de seu corpo técnico, pedagógico e de gestão nas questões do quotidiano escolar.

Portanto, parece que ainda vamos conviver por algum tempo com redes de ensino ineficazes, que ensinam pouco e que começam a reter os alunos bem no início da escolarização, os distribuindo para soluções "alternativas" (classes atrasadas, ensino de jovens e adultos, ou para fora da escola), deixando bem claro quem pode ter acesso às etapas mais avançadas do proceso educativo.

Para vencer o atraso na implantação das políticas públicas educacionais até o presente momento, a disposição por transformações educacionais no Brasil, aparentemente, resultou em duas grandes quebras de paradigma: a rápida expansão das matrículas nas últimas décadas, como já apresentado, e a consolidação de sistemas de avaliação externa em larga escala.

Da década de 1970 para cá, enquanto o Brasil fazia enorme esforço para matricular suas crianças e jovens no ensino primário e secundário, muitos países faziam alterações substanciais em seus sistemas educacionais, mas, já tendo vencido a etapa inicial de estruturar seus sistemas de atendimento educacional, partiam para reformas mais profundas, que requeriam recursos humanos e materiais com maiores graus de sofisticação. Hargreaves e Fullan (2009) 
apresentam quatro ondas ou fases de mudanças educacionais, vividas, principalmente, por países anglo-saxões, relacionadas ao seu contexto macroenômico e estágio de desenvolvimento de seu sistema educacional como um todo. A primeira, das décadas de 1960/70, era de uma certa euforia civil, decorrente do sucesso das pressões pela expansão de direitos civis e de abundância de recursos; a segunda, chamada pelo autor de interregno, vai do final dos anos 1970 ao início dos 1990 e é marcada pela escassez de recursos para educação provocada pela crise mundial do Petróleo e pela mudança de prioridades da geração conhecida como "baby boomers", que já estava mais preocupada com a aposentadoria que com a instrução. Nesse período, a educação em muitos países viveu uma onda de competição e de inspiração em mecanismos de mercado para aumentar a eficiência do setor; a terceira fase, denominada pelo autor de "segunda onda" no início dos anos 2000, foi uma época de responsabilização pública, padronização, supervisão e controle externo e a "terceira onda" que parece tirar o melhor das anteriores, com uma "efervescência" de inovação aliada ao controle externo e padronização.

Aparentemente o Brasil não viveu intensamente nenhuma dessas ondas de reformas educacionais, embora tenha vivido, com intensidades diferentes, as experiências econômicas mundiais. A intensificação da massificação do ensino, nos anos 1960 e 1970, tinha como pano de fundo o "milagre econômico" e impossibilidade de se organizar a demanda e o controle social da educação por parte da sociedade, devido ao regime político ditatorial intermitente típico da história brasileira.

Assim, a partir de 1940 a política de ampliação das oportunidades de escolarização concentrou-se, basicamente, na construção de prédios escolares, na compra de material escolar, muitas vezes de segunda categoria, e na precarização do trabalho docente pelo aviltamento dos salários e das condições de trabalho.

Com isso, nunca houve, de fato, um debate público consistente sobre a melhoria da qualidade do ensino oferecido pela escola pública brasileira. Os nossos políticos primaram pela construção de escolas para toda a população, sem que fosse dada a ênfase necessária na questão da qualidade do ensino a ser oferecido por essas escolas.(PORTELA \& ARAUJO, 2005, pg.9) [grifo meu] 
Para vencer a etapa de matricular alunos, ainda sem uma preocupação intrínseca com a qualidade, na linha das "adaptações" apontadas por Gatti e Barretto (2009), a massificação das redes de ensino se deu com mais de um turno de aulas por escola, com, às vezes, mais de três.

Os 200 dias letivos, com 4 horas de aula, que totalizavam o mínimo de 800 horas de aula anuais obrigatórias, só foi estabelecido pela LDB de $1996^{49}$. Ainda hoje, o número médio de horas-aulas por dia é está abaixo de cinco ${ }^{50}$. Em São Paulo o mínimo de horas-aula por dia foi alterado para esse patamar em 1995.

Gráfico 5: Número de aulas aula-dia por etapa de ensino - Regiões do Brasil e Estado de São Paulo

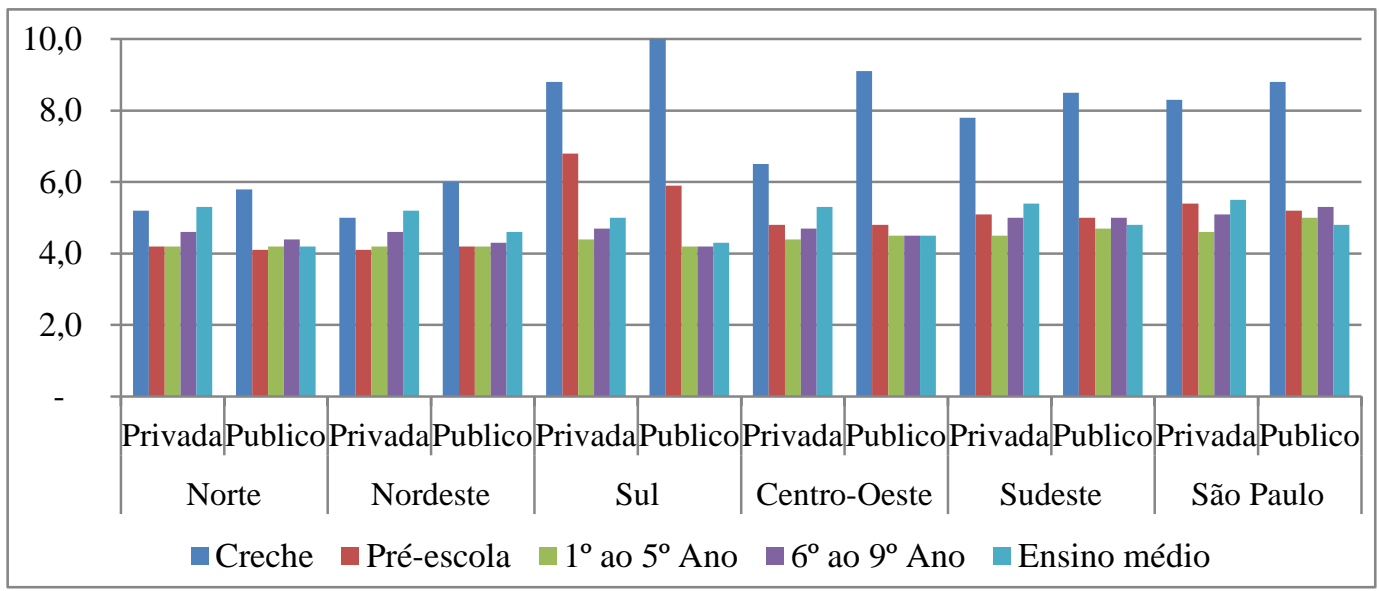

Fonte: INEP, Indicadores Educacionais. Tabulação própria.

\subsection{A avaliação em larga escala como parte essencial da evolução educacional recente no Brasil}

Em relação à América Latina, Gajardo (2000) apresenta um resumo das reformas na região na década de 1990, dividindo-as em quatro grupos de iniciativas. Nesse resumo a autora faz uma compilação de recomendações de órgãos como o Banco Interamericano de Desenvolvimento (BID), Banco Mundial e do Tratado de Jomtien. Comparando-as com a realidade brasileira, percebe-se

49 Art. 24. A educação básica, nos níveis fundamental e médio, será organizada de acordo com as seguintes regras comuns: I - a carga horária mínima anual será de oitocentas horas, distribuídas por um mínimo de duzentos dias de efetivo trabalho escolar, excluído o tempo reservado aos exames finais, quando houver.

50 Não foram encontrados dados comparáveis para os países do painel, mas a média de horas compulsórias de instrução na OCDE é de 6497 dos 7 a 14 anos. Com 800 horas/ano, para o mesmo período os brasileiros estariam expostos a 6400. Sendo que alguns países da Europa têm mais de 7000 horas 
que a maior parte do que é frequentemente chamado de "agenda imposta por organismos internacionais" ficou longe das reformas realmente implementadas no Brasil.

Tabela 9: Gajardo, 1999 - Eixos e estratégias nas orientações de política educacional na década de 1990

\begin{tabular}{|c|c|}
\hline Eixos de Política & Estratégias/Programas \\
\hline Gestão & $\begin{array}{l}\text { Descentralização administrativa e pedagógica } \\
\text { Fortalecimento das capacidades de gestão } \\
\text { Autonomia escolar e participação local } \\
\text { Melhoria dos sistemas de informações e gestão } \\
\text { Avaliação/aferição de resultados, prestação de contas à sociedade } \\
\text { Participação dos pais, governos e comunidades locais }\end{array}$ \\
\hline Eqüidade e Qualidade & $\begin{array}{l}\text { Enfoque nas escolas mais pobres dos níveis básicos } \\
\text { Discriminação positiva para grupos vulneráveis (pobres e indigentes } \\
\text { urbanos e rurais, população indígena, mulheres pobres e indígenas) } \\
\text { Reformas curriculares } \\
\text { Fornecimento de textos e materiais de instrução } \\
\text { Extensão da jornada escolar/aumento de horas de aula } \\
\text { Programas de melhoria e inovação pedagógica } \\
\text { Programas de fortalecimento institucional }\end{array}$ \\
\hline $\begin{array}{l}\text { Aperfeiçoamento dos } \\
\text { Professores }\end{array}$ & $\begin{array}{l}\text { Desenvolvimento profissional dos docentes } \\
\text { Remuneração por desempenho } \\
\text { Políticas de incentivos }\end{array}$ \\
\hline Financiamento & $\begin{array}{l}\text { Subsídio à demanda } \\
\text { Financiamento compartilhado } \\
\text { Mobilização de recursos do setor privado } \\
\text { Redistribuição/impostos x educação } \\
\text { Uso efetivo de recursos existentes (racionalização) }\end{array}$ \\
\hline \multicolumn{2}{|c|}{$\begin{array}{l}\text { Nota: os eixos de política estão organizados segundo as quatro grandes áreas de reforma e as } \\
\text { orientações políticas predominantes na década dos noventa. }\end{array}$} \\
\hline
\end{tabular}

Fonte: GAJARDO, 1999, pg:13

E, mesmo do que diz respeito à autonomia escolar, um termo muito caro ao ambiente educacional brasileiro, que poderia estar subjacente a uma filosofia realmente participativa e democrática ensejada com o novo regime democrático no país, ficamos longe de mudanças que pudessem tornar escolas e docentes atores mais relevantes e prestigiados no contexto do Brasil, pelo menos, se for tomado como referência o esquema a seguir.

Tabela 10: OCDE - Categorias de decisão autônoma em gestão educacional

\begin{tabular}{|l|l|}
\hline Organização da & Seleção da escola para o aluno \\
instrução & Tipo de percurso do aluno \\
& Tempo de instrução \\
& Escolha de livros didáticos \\
& Critérios de enturmação \\
& Atividades de reforço para os alunos \\
& Métodos de ensino \\
& Métodos de avaliação do dia a dia dos alunos \\
\hline
\end{tabular}




\begin{tabular}{|l|l|}
\hline Administração de & Contratação de Diretores, docentes e especialistas \\
pessoal & Demissão de Diretores, docentes e especialistas \\
Atribuições e condiçães de serviço para Diretores, \\
docentes e especialistas \\
& Estrutura de remuneração de Diretores, docentes e \\
especialistas \\
& Carreiras de Diretores, docentes e especialistas \\
\hline Planejamento e & Instalação e encerramento de escolas \\
estrutura & Criação e eliminação de níveis de ensino \\
& Desenho de programas para tipos específicos de escolas \\
Seleção de programas oferecidos pelas escolas \\
& Escopo das disciplinas oferecidas pelas escolas \\
& Definição do conteúdo das disciplinas \\
& Nível de exigência para obtenção de certificados de \\
conclusão e obtenção de diplomas
\end{tabular}

Fonte: OECD, Education at a Glace, 1998. pg. 297. Tradução nossa.

Assim, das ondas de reformas vividas por muitos países, o Brasil consolidou apenas poucas delas, principalmente a descentralização das matrículas abordada neste trabalho e a implementação de um sólido sistema de avaliação educacional em larga escala em nível nacional e estadual (BROOKE \& CUNHA, 2011), assim como a participação regular em iniciativas de avaliação internacionais como o Programa Internacional de Avaliação de Estudantes (Pisa) e a Pesquisa Internacional sobre Ensino e Aprendizagem (Talis), ambos coordenados internacionalmente pela Organização para Cooperação e Desenvolvimento Econômico (OCDE) e, em âmbito nacional, pelo Instituto Nacional de Estudos e Pesquisas Educacionais Anísio Teixeira (Inep).

O site do Inep apresenta um descrição de cada uma das iniciativas:

O Pisa é aplicado de forma amostral, segundo critérios definidos pela OCDE. Caracterizam-se como alunos elegíveis para o Pisa todos aqueles na faixa dos 15 anos de idade, faixa etária em que os estudantes completaram a escolaridade obrigatória na maioria dos países. Há um corte a partir dos alunos que estão cursando pelo menos o Grau 7 (7th grade), no 
Brasil isso corresponde aos alunos matriculados acima do $8^{\circ}$ ano ( $7^{\mathrm{a}}$ série) do Ensino Fundamental até o final do Ensino Médio, desta forma mantêm-se a comparabilidade com as edições anteriores nas quais sempre foram avaliadas os dois últimos anos do ensino fundamental.

No ano 2000, o Brasil avaliou 4.893 alunos no Pisa; em 2003, 4.452 alunos. Em 2006, a amostra brasileira foi ampliada para 9.295 alunos. Em 2000 e 2003, a amostra considerava como estratos principais as regiões do país e, como substratos, a dependência administrativa (pública ou privada) e a localização da escola (rural ou urbana).

Em 2006, visando a uma representatividade mais significativa do universo das escolas, a amostra brasileira do Pisa compreendeu como estratos principais as 27 unidades da federação; e teve como substratos a organização administrativa da escola (pública ou privada), a localização (rural ou urbana, incluindo todas as capitais e cidades do interior de cada estado) e o Índice de Desenvolvimento Humano (IDH) do Estado (cidades com IDH acima ou abaixo da média do Estado). A amostra final englobou 630 escolas, sendo pelo menos 20 em cada Estado. Essa amostra, no entanto, produziu médias estaduais com erro-padrão elevado.

Em 2009, com o objetivo de produzir médias estatisticamente mais confiáveis para os Estados brasileiros no Pisa, a amostra compreendeu os mesmos estratos e substratos, mas abrangeu um número maior de escolas e de alunos em cada Estado. No total, foram 950 escolas e 20.127 alunos.

No Pisa 2012 a amostra brasileira ficou muito próxima da amostra de 2009. A novidade de 2012 foi a aplicação de testes em meio eletrônico de Matemática, Leitura e Resolução de Problemas a uma subamostra de cerca de 4.000 alunos. (http://portal.inep.gov.br/internacional-novo-pisauniversoavaliado)

Sobre a Talis:

Na primeira aplicação dessa pesquisa, realizada em 2007 e 2008, foram coletadas informações sobre liderança escolar, avaliação dos professores e feedback, desenvolvimento profissional e atitudes, crenças e práticas educacionais dos professores das séries finais do ensino fundamental $\left(6^{\circ}\right.$ a $9^{\circ}$ ano ou $5^{\mathrm{a}}$ a $8^{\mathrm{a}}$ série) e dos diretores das escolas da amostra. (http://portal.inep.gov.br/web/talis/historico-e-resultados)

$[\ldots]$

No ano de 2012, o Brasil e mais 31 países farão parte a segunda rodada da pesquisa. A TALIS é a primeira pesquisa internacional a levantar dados sobre o ambiente de 
aprendizagem e as condições de trabalho que as escolas oferecem aos professores.

$[\ldots]$

O universo da pesquisa compreende todas as escolas públicas e privadas, de todos os estados brasileiros, que possuem professores atuando em turmas do $6^{\circ}$ ao $9^{\circ}$ ano $/ 5^{\mathrm{a}}$ a $8^{\mathrm{a}}$ série. Cerca de 1000 escolas farão parte da pesquisa em 2012, estas escolas serão selecionadas aleatoriamente pelo Instituto "Statistics Canada", responsável internacionalmente pela seleção da amostra de escola dos países participantes da pesquisa. (http://portal.inep.gov.br/web/talis/pesquisa-talis)

O resultado da combinação de uma massificação com atraso com o alijamento das diversas "ondas" de reforma dos países que hoje são mais industralizados que o Brasil, é uma grande dificuldade para superar as dificuldades descritas por Rui Barbosa, Anísio Teixeira, os Pioneiros da Educação ou Costa Ribeiro e alcançar patamares mais altos de qualidade para o país como um todo, como mostram as sucessivas edições do Pisa.

Gráfico 6: Evolução comparativa dos resultados no PISA desde 2000 - G20

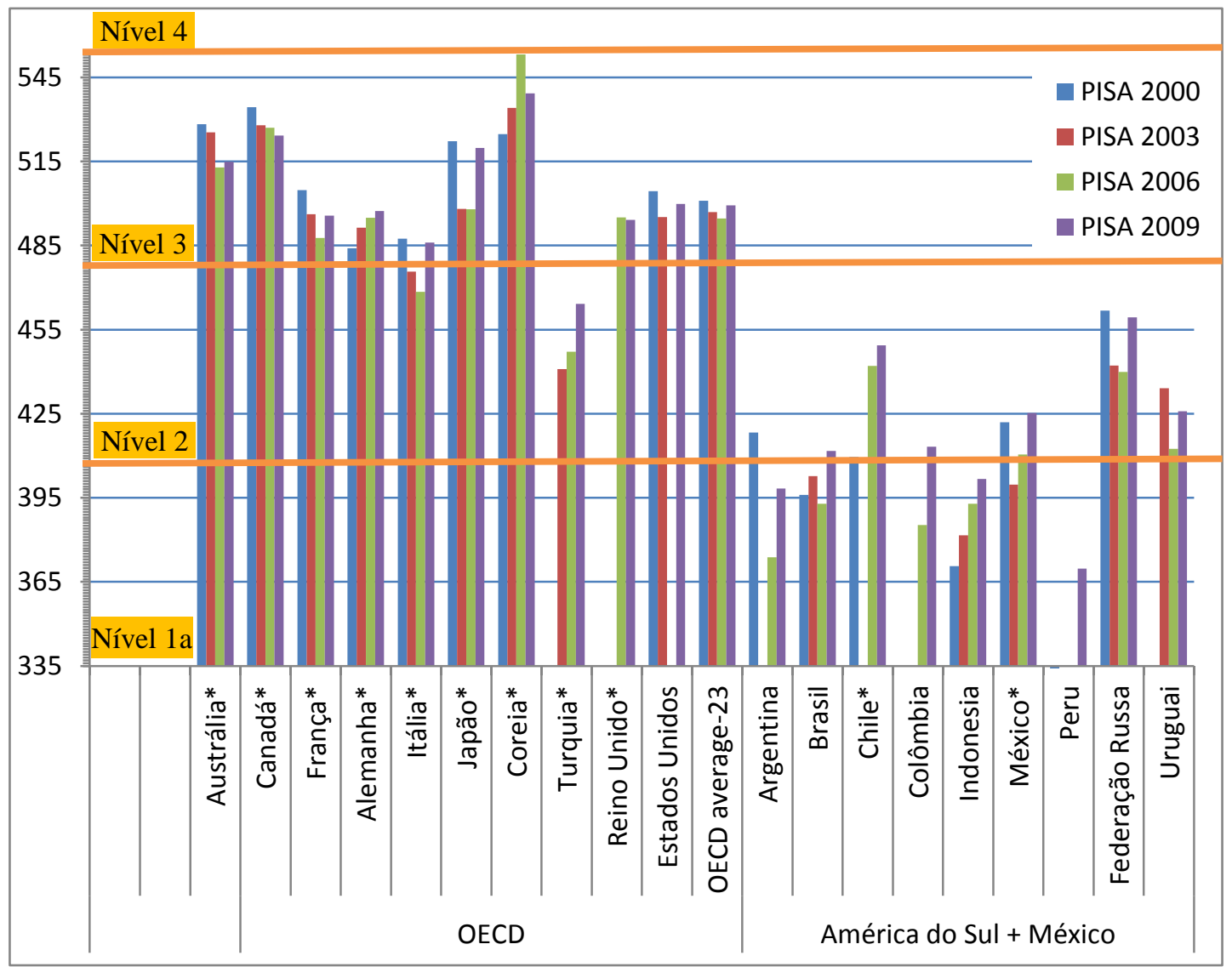

Fonte: Relatório Pisa 2009. Tabulação própria. 
Por fim, para completar a descrição do contexto educacional brasileiro, apesar de os dados de frequência escolar do Censo de 2010 mostrarem que 95\% das crianças brasileiras aos 6 anos estão na escola, aos 8 anos apenas $76 \%$ estão entre o segundo e o quarto ano, como seria esperado para a idade. Aos 17, quando todos deveriam estar nos últimos anos do ensino médio, apenas $39 \%$ estão no segundo ano dessa etapa ou além e $26 \%$ já saíram da escola.

Soares et al. (2012), com os dados da Prova Brasil de 2005 a 2009 mostram que $22 \%$ dos alunos terminam o ensino fundamental sem dominar habilidades elementares de leitura e $39 \%$ de matemática. No mesmo estudo, os autores também mostram que o baixo desempenho está intimamente relacionado com características de vulnerabilidade dos alunos como nível socioeconomico e cor. 


\section{O contexto educacional paulista}

\subsection{Ritmo de evolução da distribuição das matrículas}

Este capítulo procura responder à primeira pergunta desta pesquisa: como se deu a distribuição das matrículas no Estado de São Paulo em uma perspectiva temporal (desde a Constituição Federal de 1988, mas principalmente após a implementação do Fundef/b, até os dados mais recentes disponíveis) e, em uma perspectiva comparativa, se há alguma característica sistemática dos municípios que os diferencie em termos do ritmo de municipalização.

O início do processo de descentralização de matrículas do ensino fundamental no Estado de São Paulo é diferente daquele de outras unidades da Federação, principalmente aquelas localizadas nas regiões Norte e Nordeste, que começaram, mais de uma década antes, a transferir matrículas do nível estadual para o municipal. Mesmo que algumas ações no sentido de compartilhar, ou simplesmente transferir, responsabilidades relacionadas à educação já tivessem sido implementadas em gestões anteriores, um dos aspectos que não se discute em relação à transferência de matrículas do estado para os municípios no Estado de São Paulo é o de que ela teve efetivamente início político, ideológico e operacional na gestão Mário Covas (Governador) - Rose Neubauer (Secretária de Educação), entre 1995 e 2001. A visão da administração Covas-Neubauer a respeito da relação que o estado deveria manter com seus municípios na operação dos serviços de educação era a de parceria, descrita nas palavras da então Secretária de Educação (NEUBAUER, 1996):

Para esta administração, municipalizar significa criar e fortalecer a parceria com os governos municipais. Estabelecidas as diretrizes gerais norteadoras da relação Estado-Município e as específicas na prestação do serviço ao cidadão, a relação direta com a população demandatária compete ao município. Municipalizar, pois, vai além de descentralizar, de desconcentrar: o município compartilha responsabilidades a 
partir de negociações estabelecidas caso a caso. Desconcentrar, descentralizar e municipalizar são formas que se complementam, na distribuição do poder e da decisão sobre os recursos financeiros que o sustentam. [. . .] (NEUBAUER, 1996, pg. 71)

O governo do Estado e a Secretaria da Educação sabem que a descentralização não irá resolver todos os problemas do ensino público. Acredita-se também que o caminho da descentralização não dispensa o Estado e a Secretaria da Educação de trabalharem pela melhoria da educação básica. Ao contrário, o Estado deverá potencializar seu papel de planejador e coordenador de políticas públicas, através do estabelecimento de diretrizes sobre conteúdos curriculares básicos, uso racional dos recursos, avaliação dos resultados de ensino, transferência de recursos e garantia de eqüidade, para compensar as desigualdades entre os municípios. (idem, pg. 72)

No Estado de São Paulo houve, então, um primeiro impulso autóctone dado por um conjunto de providências e convênios elaborados nessa administração (NEUBAUER, 1996; LUCIO, 2005; GOMES 2008; ADRIÃO, 2008), seguido, em 1998, por um estímulo federal dado pela implementação do Fundo de Manutenção e Desenvolvimento do Ensino Fundamental e de Valorização do Magistério (Fundef). Esses eventos não são aleatórios, uma vez que os grupos políticos que governavam o Estado e o Governo Federal eram ideologicamente alinhados com o princípio da descentralização. As matrículas totais da educação básica no estado apresentaram o desenrolar ilustrado pelo gráfico a seguir, no qual se pode perceber que o pico de matrículas foi anterior ao início da descentralização, que há realmente uma alteração substancial na distribuição das matrículas ao longo do tempo e que ela continua, pelo menos, até 2011. Além disso, é possível perceber que a rede particular vem ocupando cada vez mais espaço no atendimento educacional no estado. Atualmente são, então, três atores relevantes no atendimento da educação básica: o estado, o conjunto dos municípios e o conjunto das particulares, que dividem o atendimento com, respectivamente, $40 \%, 39 \%$ e $21 \%$ dos alunos. 
Gráfico 7: Evolução das matrículas da educação básica no Estado de São Paulo por dependência administrativa (1991, 1996, 2000-2011)

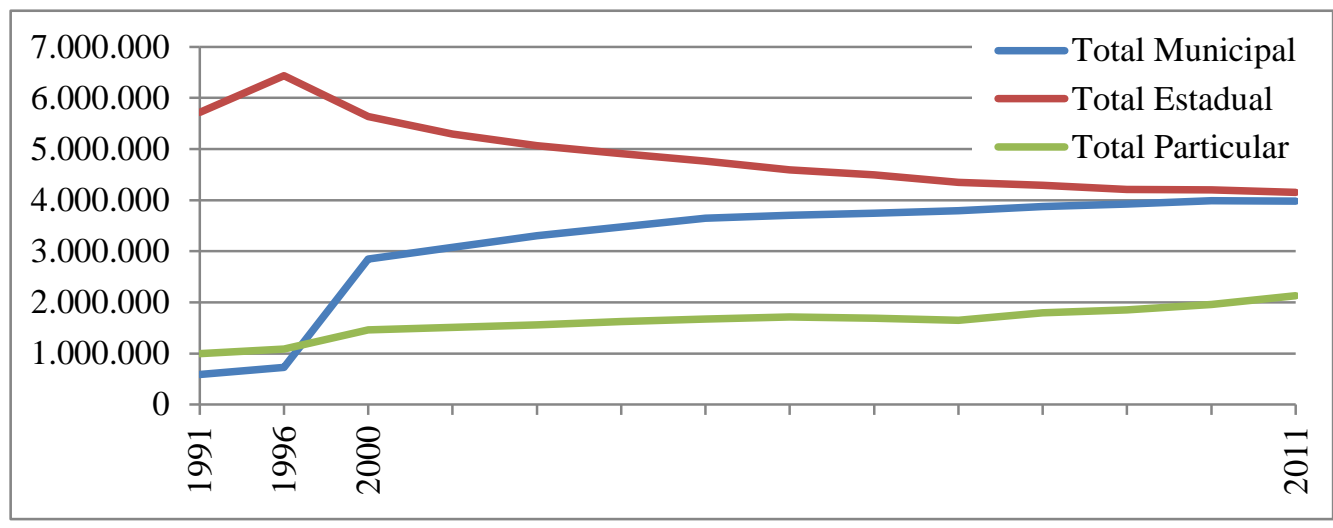

Fonte: Fundação Seade. Cálculos e tabulação próprios.

O processo de transferência de matrículas conduzido pela Secretaria Estadual de Educação de São Paulo tem como principal mecanismo legal um convênio assinado entre o estado e cada município. A legislação que rege a municipalização em São Paulo é composta pelos seguintes grupos de instrumentos:

1) Formalização do processo dentro do estado - Decreto $\mathrm{n}^{\circ} 40.673$, de 16/02/96, alterado pelo Decreto $n^{\circ} 40.889$, de 20/06/96, Decreto $n^{\circ} 41.054$, de 29/07/96 alterado pelo Decreto 45.777, de 26/04/01: institui o Programa Ação de Parceria entre Estado e Município e autoriza a transferência das escolas do estado para os municípios, inicialmente por cinco anos e depois por tempo indeterminado; Decreto $n^{\circ} 42.535$ de 24 de Novembro de 1997: Dispõe sobre a extinção das escolas e classes de escolas estaduais transferidas aos municípios, nos termos do Decreto $\mathrm{N}^{\circ} 41.054$, de 29 de julho de 1996, e dá providências correlatas; Lei no 14.461 de 25 de Maio de 2011 que autoriza a Fazenda do Estado a transferir aos municípios o domínio, mediante doação, e a ceder direitos possessórios, a título gratuito, relativos aos imóveis que especifica, e dá providências correlatas.

2) Detalhes sobre a organização das redes de ensino no estado - Deliberação CEE No 11/97 e Indicação CEE No 10/97 Aprovada em 30.09.97: dispõe sobre os sistemas municipais de ensino e da outras providências;

3) Formalização das transferências de recursos humanos - Resolução SE N ${ }^{\circ}$ 139, de 19 de setembro de 1997: Dispõe sobre providências a serem adotadas pelas Delegacias de Ensino no Programa de Ação de Parceira 
Educacional Estado-Município para Atendimento ao Ensino Fundamental, Resolução SE $N^{\circ}$ 141, de 24 de setembro de 1997: Dispõe sobre transferências de servidores e dá providências e Instrução DRHU $\mathrm{N}^{\circ} 8$, de 25 de setembro de 1997: dispõe sobre providências a serem tomadas sobre transferência de servidores, conforme o disposto no artigo $6^{\circ}$ da Resolução SE $n^{\circ} 141 / 97$

4) Convênio de transferência entre estado e cada município - Decreto $\mathrm{n}^{\circ}$ 43.072, de 04/05/98, substituído pelo Decreto n ${ }^{\circ}$ 51.673, de 19/03/2007: Elenca os objetivos e as obrigações da Fase II do Programa Ação de Parceria entre Estado e Município, já adequada ao Fundeb, cujos principais pontos estão elencados a seguir:

Objetivos do convênio:

I.Estabelecer um processo de parceria técnico-administrativa entre o Estado e o Município, para viabilizar a assunção integral ou parcial, pelo Município, dos serviços referentes à gestão do ensino fundamental;

II.Instituir um sistema de cooperação com os municípios, envolvendo a transferência de recursos humanos, materiais e financeiros, para que estes assumam de forma integrada as responsabilidades pelo ensino fundamental;

III.Fortalecer a autonomia do poder local na busca de uma escola pública de qualidade para todos;

IV.Garantir assistência técnica, pedagógica, administrativa e gerencial aos Municípios, para que estes desenvolvam o ensino fundamental em conformidade com as diretrizes constitucionais;

V.Colaborar com a capacitação das redes municipais de ensino, visando a manutenção de um padrão de qualidade de ensino para todas as escolas;

VI.Criar mecanismos de compensação que superem as desigualdades financeiras, administrativas e técnicas dos municípios na implementação dos programas educacionais;

VII. Instituir uma sistemática de avaliação dos sistemas de ensino, visando ao seu aprimoramento.

Por esse instrumento, os municípios recebem do estado: 
a) Pessoal docente, técnico e administrativo, afastados junto ao município, sem prejuízo de vencimentos ou salários e das demais vantagens, por solicitação expressa do chefe do poder executivo do município;

b) Permissão de uso dos bens imóveis de propriedade do estado, utilizados pelo município na prestação de serviços educacionais,

c) Cessão de uso dos bens móveis e materiais didáticos de propriedade do estado, destinados estritamente à prestação dos serviços educacionais transferidos e que constituam patrimônio das escolas estaduais absorvidas pelo município

E se obrigam a criar as condições locais para institucionalização do processo:

a) Criar ou adequar o Conselho Municipal de Educação, elaborar o Plano Municipal de Educação, integrando-o às políticas e planos educacionais do Estado, em consonância com as diretrizes e planos nacionais de educação;

b) Instituir ou adequar o Plano de Carreira e Remuneração do Magistério municipal de acordo com as diretrizes do Conselho Nacional de Educação;

c) Garantir condições para continuidade das Associações de Pais e Mestres ou entidade similar, assegurando a presença de instituições auxiliares da escola;

Assim como manter os imóveis cedidos pelo estado ao município para as atividades escolares, e, quanto aos recursos humanos:

a) Realizar, no decorrer dos 12 (doze) meses, contados da assinatura do convênio, processo seletivo ou concurso público para ingresso, em quadros próprios do município, de profissionais do magistério, pessoal técnico e administrativo, necessários à execução das ações previstas no plano de trabalho; 
b) Instituir mecanismos de controle de freqüência dos docentes e do pessoal técnico e administrativo, afastados junto ao município, a fim de ser assegurado o processamento de seus direitos e vantagens;

c) Repor o pessoal docente, técnico e administrativo, nos casos de licença e vacância do cargo e da função ou quando houver necessidade de ampliação do quadro por expansão da rede escolar municipal, de forma a assegurar a perfeita execução do objeto conveniado.

Além do convênio propriamente dito, outras providências tinham como objetivo a integração gradual dos esforços educacionais dos diferentes entes federados no estado, como, por exemplo, o sistema de matrícula conjunta iniciado em 1999, que tinha como objetivo, por meio de um cadastro único de alunos, a otimização entre oferta e demanda de vagas para o ensino fundamental.

A partir de 2000 foi elaborado um Projeto de Acompanhamento da Municipalização que concluiu, por visitas, registros e entrevistas em uma amostra de 150 cidades, o seguinte ${ }^{51}$ :

1) Em relação à Administração Municipal: autonomia na gestão do ensino fundamental, organização de sistema próprio de ensino, verba para construções escolares e reformas, financiamento do transporte escolar;

2) Em relação aos professores: concurso público para seleção, capacitação permanente, apoio de coordenadores pedagógicos municipais e de supervisores estaduais, plano de carreira e remuneração.

3) Em relação a comunidades: participação na vida escolar, facilidade de contato direto com os gestores de educação no município, voz ativa no Conselho Municipal de Educação, participação na administração escolar por meio das APMs, ensino de qualidade para seus filhos.

4) Em relação aos alunos: escolas bem construídas, conservadas e bem administradas, material didático equipamento de informática para facilitar e modernizar o aprendizado, programas de reforço para apoiar 
a recuperação de dificuldades, classes de aceleração de estudos para recuperar alunos com defasagem idade/série, participação em projetos de educação ambiental, artes e esportes, transporte escolar para alunos da zona rural, merenda mais farta, nutritiva e saborosa, avaliações periódicas para garantir o aprendizado.

Este trabalho não se propõe a verificar se o que o Projeto de Acompanhamento observou realmente reflete a realidade, mas, como primeira constatação, aparentemente, o desenho legal e os resultados relatados estão alinhados.

A transferência maciça de escolas tem início, então, em 1996 (GOMES, 2008). À época, apenas 10 municípios $^{52}$ dos 645 existentes tinham $100 \%$ das matrículas dos anos iniciais do Ensino Fundamental municipalizadas e outros 11 contavam com, pelo menos, $50 \%$ da matrícula sob sua responsabilidade ${ }^{53}$. Em 2000, esses números eram, respectivamente, de 238 e 101.

Como se viu no resumo da legislação, a unidade de transferência é a escola. Portanto, para cada ano fiscal pode-se ter um percentual diferente de municipalização em cada cidade, o que evidencia ritmos diferentes de absorção de matrículas em nível local, que pode ser medido. Identificar que variáveis locais podem influenciar esse ritmo de absorção de matrículas será o recurso utilizado para compreender em maior profundidade o processo de municipalização no Estado de São Paulo.

Em um mesmo ponto no tempo pode-se encontrar cidades com a proporção entre número de matrículas em escolas municipais e o total das matrículas em escolas estaduais e municipais, variando de zero a $100 \%$, conforme dimensionado no eixo vertical dos gráficos a seguir. 
Gráfico 8 A e B: Evolução da municipalização no Estado de São Paulo - anos iniciais e finais (1996-2012)

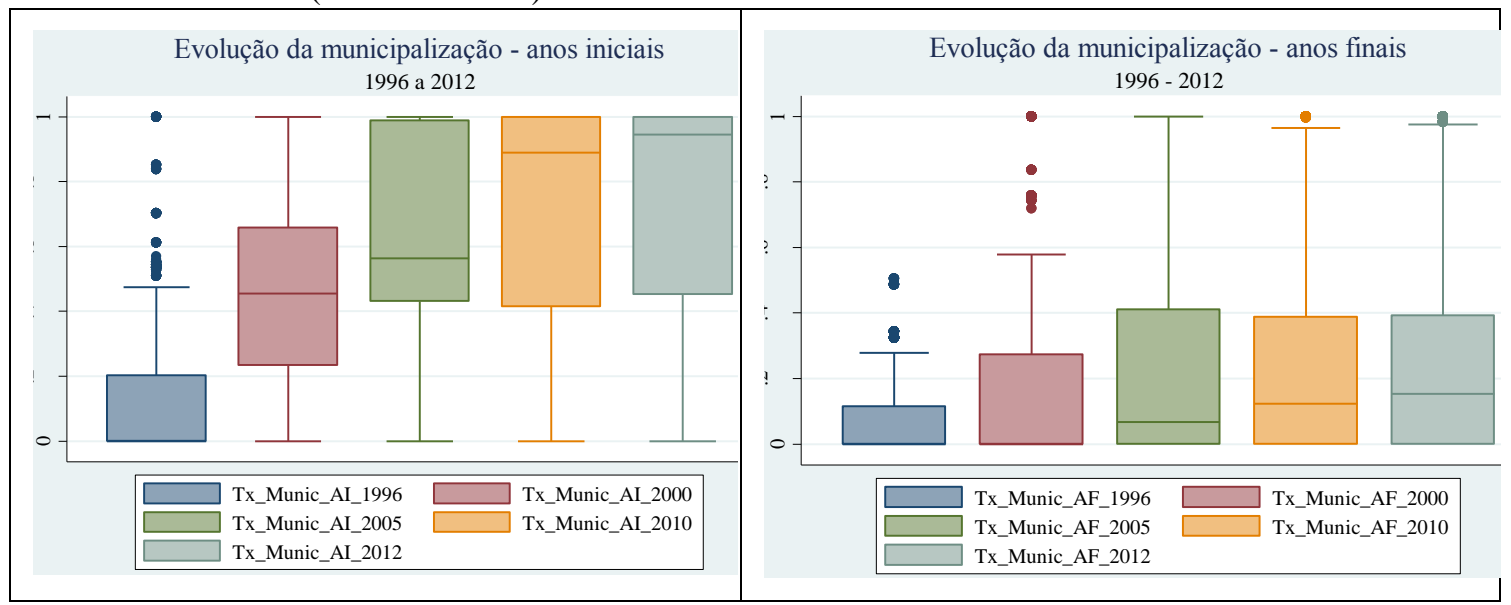

Fonte: Fundação Seade. Cálculos e tabulação próprias.

Como está se buscando identificar características em nível municipal, foram criadas cinco categorias de nível de municipalização. Cada município se encaixa em uma categoria em um dado momento no tempo, mas, para a caracterização dos grupos que se faz a seguir, será levada em conta a proporção de matrículas do ano de 2012. A ideia inicial era dividir os 645 municípios do estado em quatro níveis subsequentes de municipalização. Entretanto, pelo foco de interesse da pesquisa, um grupo se destacou dos demais e mereceu ser analisado isoladamente: o dos municípios totalmente municipalizados em cada etapa. Desta forma, os dados serão apresentados em cinco grupos: de zero a $25 \%$, de $26 \%$ a $50 \%$, de $51 \%$ a $75 \%$, de $76 \%$ a $99 \%$ e o de $100 \%$.

Nas duas tabelas a seguir pode-se acompanhar a evolução do número de municípios pelas cinco faixas de municipalização, nos seguintes pontos no tempo: desde o início do processo (1996), em três momentos a cada cinco anos (2000, 2005 e 2010) e o mais recente (2012). É possível perceber que o período de 19962000 foi realmente radical em termos de transferências de matrículas, não só pela mudança de dependência administrativa de escolas, mas porque uma grande quantidade de municípios tornou-se $100 \%$ municipalizada em um curto lapso de tempo. Se é verdade que muitos municípios contavam com apenas uma escola, essa não é a regra, e as cidades se organizaram para receber e administrar o conjunto dos serviços públicos de educação que estavam, até aquele momento, nas mãos do Estado. Outro aspecto a ser destacado é que, pelo menos até os dados mais recentes de 2012, o processo não se encerrou, embora tenha reduzido a 
velocidade, uma vez que são poucos os muncípios que ainda não aderiram de forma substancial ao processo de transferência. Mesmo assim, 33 deles, ou 5\% do total, optaram por não municipalizar nada ou o fizeram para menos de 1/4 de sua rede.

Tabela 11: Evolução do número de municípios por faixa de municipalização nos anos iniciais do ensino fundamental (1996-2012)

\begin{tabular}{lrrrrrrr}
\hline Anos Iniciais & $\mathbf{1 9 9 6}$ & $\mathbf{2 0 0 0}$ & $\mathbf{2 0 0 5}$ & $\mathbf{2 0 1 0}$ & $\mathbf{2 0 1 2}$ & $\begin{array}{r}\text { \% em } \\
\mathbf{1 9 9 6}\end{array}$ & $\begin{array}{r}\text { em } \\
\mathbf{2 0 1 2}\end{array}$ \\
\hline $100 \%$ & 10 & 238 & 371 & 478 & 492 & $2 \%$ & $76 \%$ \\
\hline $76-99 \%$ & 2 & 34 & 74 & 73 & 73 & $0 \%$ & $11 \%$ \\
\hline $51-75 \%$ & 9 & 66 & 36 & 34 & 29 & $1 \%$ & $4 \%$ \\
\hline $26-50 \%$ & 16 & 84 & 56 & 23 & 18 & $2 \%$ & $3 \%$ \\
\hline $0-25 \%$ & 608 & 223 & 108 & 37 & 33 & $94 \%$ & $5 \%$ \\
\hline Total & 645 & 645 & 645 & 645 & 645 & $100 \%$ & $100 \%$ \\
\hline
\end{tabular}

Fonte: Fundação Seade. Cálculos e tabulação próprios.

Tabela 12: Evolução do número de municípios por faixa de municipalização nos anos finais do ensino fundamental (1996-2012)

\begin{tabular}{lrrrrrrr}
\hline Anos Finais & $\mathbf{1 9 9 6}$ & $\mathbf{2 0 0 0}$ & $\mathbf{2 0 0 5}$ & $\mathbf{2 0 1 0}$ & $\mathbf{2 0 1 2}$ & $\begin{array}{r}\text { \% em } \\
\mathbf{1 9 9 6}\end{array}$ & $\begin{array}{r}\mathbf{2 0 1 2} \\
\hline 100 \%\end{array}$ \\
\hline $76-99 \%$ & 0 & 44 & 89 & 121 & 120 & $0 \%$ & $19 \%$ \\
\hline $51-75 \%$ & 1 & 2 & 14 & 15 & 23 & $0 \%$ & $4 \%$ \\
\hline $26-50 \%$ & 4 & 31 & 37 & 41 & 41 & $1 \%$ & $6 \%$ \\
\hline $0-25 \%$ & 640 & 563 & 482 & 441 & 431 & $99 \%$ & $67 \%$ \\
\hline Total & 645 & 645 & 645 & 645 & 645 & $100 \%$ & $100 \%$ \\
\hline
\end{tabular}

Fonte: Fundação Seade. Cálculos e tabulação próprios.

Além da municipalização total dos anos iniciais do ensino fundamental em $76 \%$ dos 645 municípios do estado, houve também transferência da totalidade das matrículas dos anos finais para 19\% deles, embora em um ritmo mais lento e com saldo final menor, conforme mostrado na tabela acima. Nela se percebe uma tendência à municipalização também nessa etapa, que já tinha sido ilustrada no gráfico da página 88 .

Com a tabulação dos municípios dessa forma, já foi possível encontrar dois grupos de interesse para uma análise mais detalhada: o grupo de municípios que, em 2012, já controlam $100 \%$ das matrículas das duas etapas do ensino fundamental e o dos que, até o mesmo ano, municipalizaram entre zero e $25 \%$ das matrículas em qualquer uma das etapas.

Dos 645 municípios do estado, 42 optaram por constituir rede própria (dados de 2012), ao invés de receber matrículas do estado. O número reduzido 
dessa opção talvez seja um indicativo da conveniência de se optar pela transferência de alunos, patrimônio e docentes, conforme oferecido pelo estado, uma vez que os demais municípios o fizeram. A tabela a seguir mostra a distribuição dos municípios que, em 2012, contavam com rede própria, usando as mesmas categorias de municipalização, e em dois momentos: no início do processo, em 1996, e o mais atual disponível, em 2012. De uma forma alternativa à municipalização pelo estado, os municípios parecem também aderir à ideia de controlar sua própria rede como opção para gerí-la.

Tabela 13: Distribuição do número de municípios com rede própria por faixa de municipalização (1996/2012)

\begin{tabular}{lrc}
\hline Anos iniciais & $\mathbf{1 9 9 6}$ & $\mathbf{2 0 1 2}$ \\
\hline $100 \%$ & 0 & 12 \\
\hline $76-99 \%$ & 0 & 10 \\
\hline $51-75 \%$ & 1 & 9 \\
\hline $26-50 \%$ & 3 & 7 \\
\hline $0-25 \%$ & 38 & 4 \\
\hline Total & 42 & 42 \\
\hline
\end{tabular}

Fonte: Secretaria de Educação do Estado de São Paulo. Tabulação e cálculos próprios.

Com o desenho da estrutura de transferência em mente, é mais fácil analisar o desenrolar do processo. A seguir, apresenta-se a primeira análise deste trabalho: a progressão do número de municípios por nível de municipalização em cada cidade em vários momentos no tempo, em relação ao nível de produção de riqueza local. Os números que representam essas duas dimensões são: o percentual de alunos em redes municipais em relação aos total de alunos da rede pública de cada município e o Produto Interno Bruto (PIB) municipal percapita (IBGE, Censo de 2010). O PIB municipal percapita no Estado de São Paulo em 2010 varia de pouco mais de $\mathrm{R} \$ 6.000$ a mais de $\mathrm{R} \$ 300.000$. Para permitir uma análise mais simplificada, foram criadas 5 faixas ordenadas desse dado ${ }^{54}$.

Os dois gráficos a seguir apresentam, no eixo vertical, a distribuição dos municípios por nível de municipalização em duas etapas do processo, a do início e a mais recente. No eixo horizontal estão os cinco níveis de PIB percapita

54 Em Reais de 2010: muito baixa (nível 1) - até $\mathrm{R} \$ 10.000,00$; baixa (nível 2) - de $\mathrm{R} \$ 10.001$ a $\mathrm{R} \$ 20.000$; média (nível 3) - de $\mathrm{R} \$ 20.001,00$ a $\mathrm{R} \$ 30.000$; alta - de $\mathrm{R} \$ 30.001,00$ a $\mathrm{R} \$ 40.000,00$ e muito alta - maior que $\mathrm{R} \$ 40.001,00$ 
municipal. No momento inicial, que compara a taxa de municipalização entre 1996 e 2000, vemos que:

a) em 1996, o grupo que contava com maior contingente de escolas municipais era o nível 3. O nível 1, de PIB percapita mais baixo, não contava com nenhuma matrícula municipal e o nível 4, praticamente nenhuma.

b) Em 2000, o grupo de municípios do nível 2 já tinha $25 \%$ dos municipios na faixa de municipalização acima de $80 \%$ e mais $25 \%$ entre $20 \%$ e $80 \%$, indicando que este foi o grupo que mais foi atraído pelas condições oferecidas pelo estado (note-se que nesse grupo quase não havia municípios com redes municipais em 1996), seguido pelos grupos 5, 3 e 4, nessa ordem. Aparentemente, a baixa produção de renda local (e, consequentemente, a falta de disponibilidade de recursos públicos para educação para além do Fundef) pode ter sido um impeditivo para o nível 1 neste primeiro momento. Para os demais grupos, o nível de renda do município não parece ter criado condições favoráveis ou desfavoráveis determinantes.

Gráfico 9: Comparação da distribuição dos municípios pelo \% de municipalização nos anos iniciais com o nível de PIB percapita (1996 e 2000)

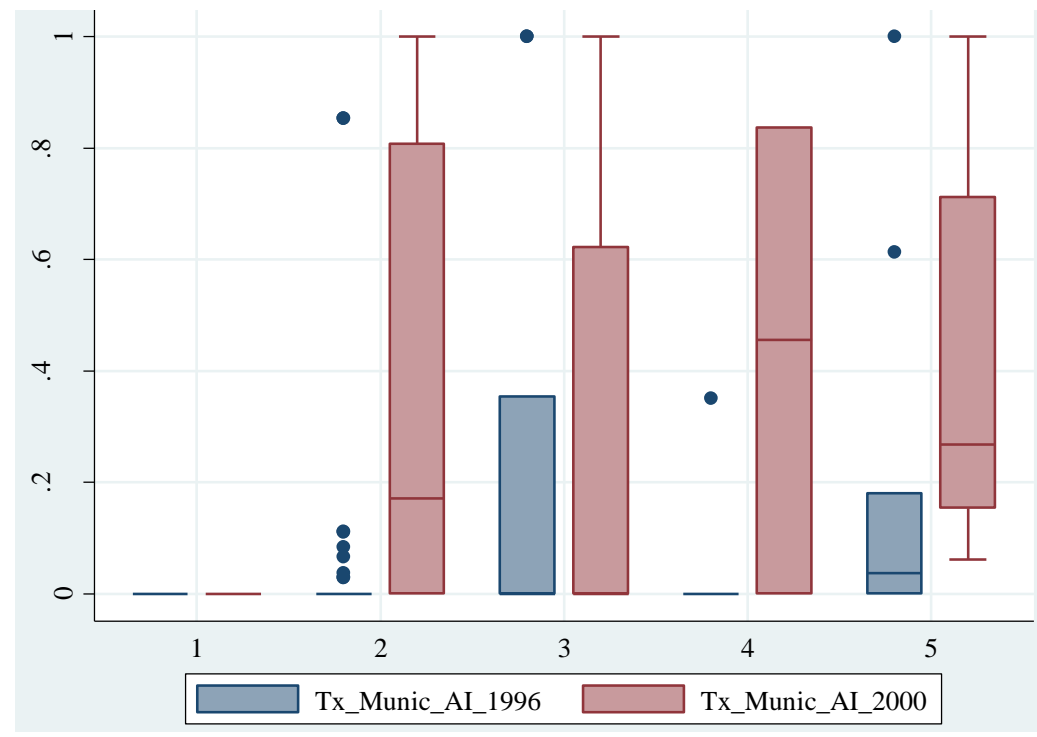

Fonte: IBGE, Censo 2010 e Fundação Seade. Tabulação e cálculos próprios

No momento mais recente da municipalização, que compara a distribuição dos municípios por faixa de municipalização em 2005 com 2012, vemos novamente (como já mostrado nas tabelas da página 89) que todos os grupos já contavam com contingene substancial, se não total, de municipalização concluída 
em 2012. O grupo de PIB percapita mais baixo, nível 1, foi totalmente municipalizado no período, enquanto os níveis 3 e 4 ainda tinham mais de 50\% de seus municípios com taxas de municipalização abaixo de $80 \%$ em 2005, mas praticamente concluíram o processo até 2012.

Gráfico 10: Comparação da distribuição dos municípios pelo \% de municipalização nos anos iniciais com o nível de PIB percapita (2005 e 2012)

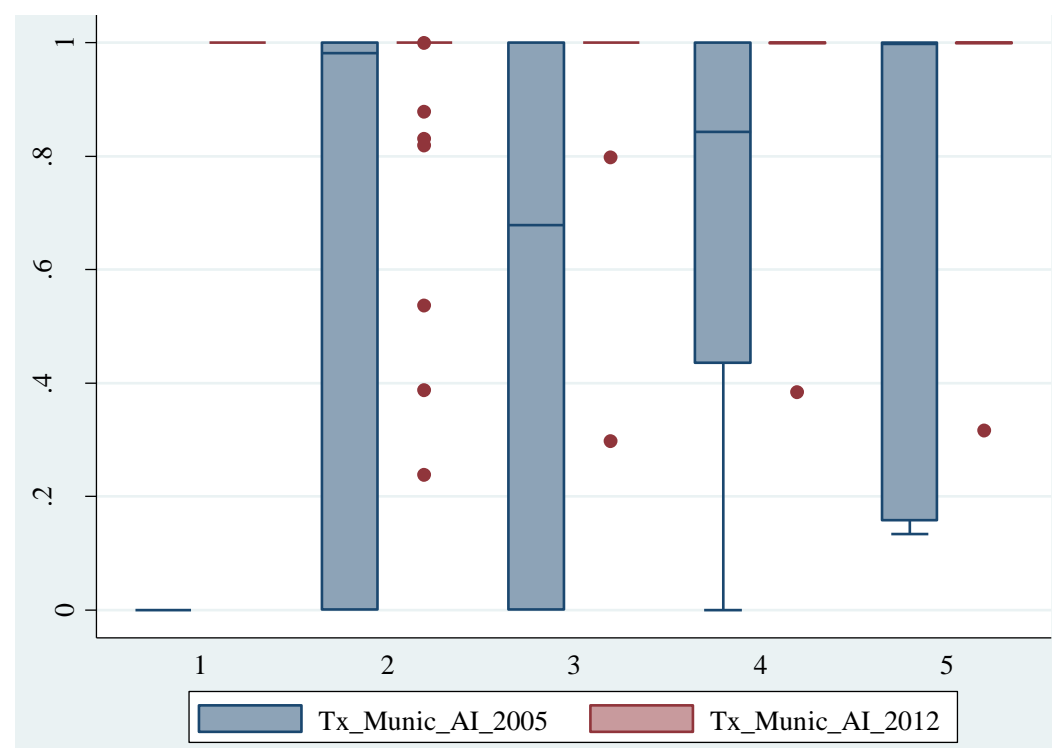

Fonte: IBGE, Censo 2010 e Fundação Seade. Tabulação e cálculos próprios

Se o PIB percapita não parece ter grande relação com o processo de transferência de matrículas, a segunda análise, por renda dos domicílios, é completamente diferente. As faixas de renda domiciliar mensal nominal percapita, cujos valores também são obtidos pelo Censo de 2010 do IBGE, foram segmentadas usando a mesma lógica que a análise anterior, mas por percentual de domicílios com renda mensal nominal percapita acima de 2 salários mínimos ${ }^{55}$. A maneiracomo se chegou a essa classificação está descrita no capítuo a seguir.

Os gráficos utilizam os mesmos lapsos temporais para mostrar a evolução dos municípios e a relação entre a renda das famílias e o processo de municipalização. Nos dois momentos há, claramente, uma relação entre a renda 
das famílias (ou do domicílio) e o nível de municipalização: quanto maior o percentual de domicílios com renda acima de dois salários mínimos, maior o percentual de municipalização, mesmo antes da aceleração do processo a partir do Fundef.

Gráfico 11: Comparação da distribuição dos municípios pelo \% de municipalização nos anos iniciais com o \% de renda domiciliar acima de $2 \mathrm{SM}$ (1996 e 2000)

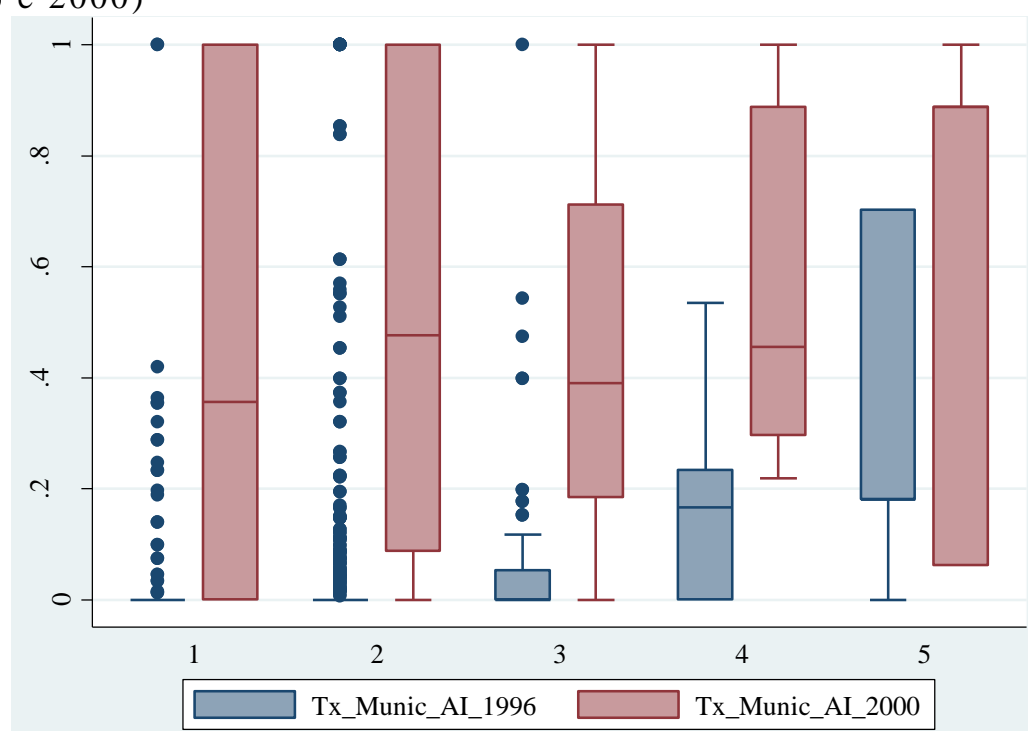

Fonte: IBGE, Censo 2010 e Fundação Seade. Tabulação e cálculos próprios

$\mathrm{Na}$ comparação dos momentos mais recentes do processo de municipalização vê-se que nos níveis 1 e 2 "sobraram" muito mais municípios com percentuais de municipalização mais baixos que nos demais.

Gráfico 12: Comparação da distribuição dos municípios pelo \% de municipalização nos anos iniciais com o \% de renda domiciliar acima de $2 \mathrm{SM}$ (2005 e 2012)

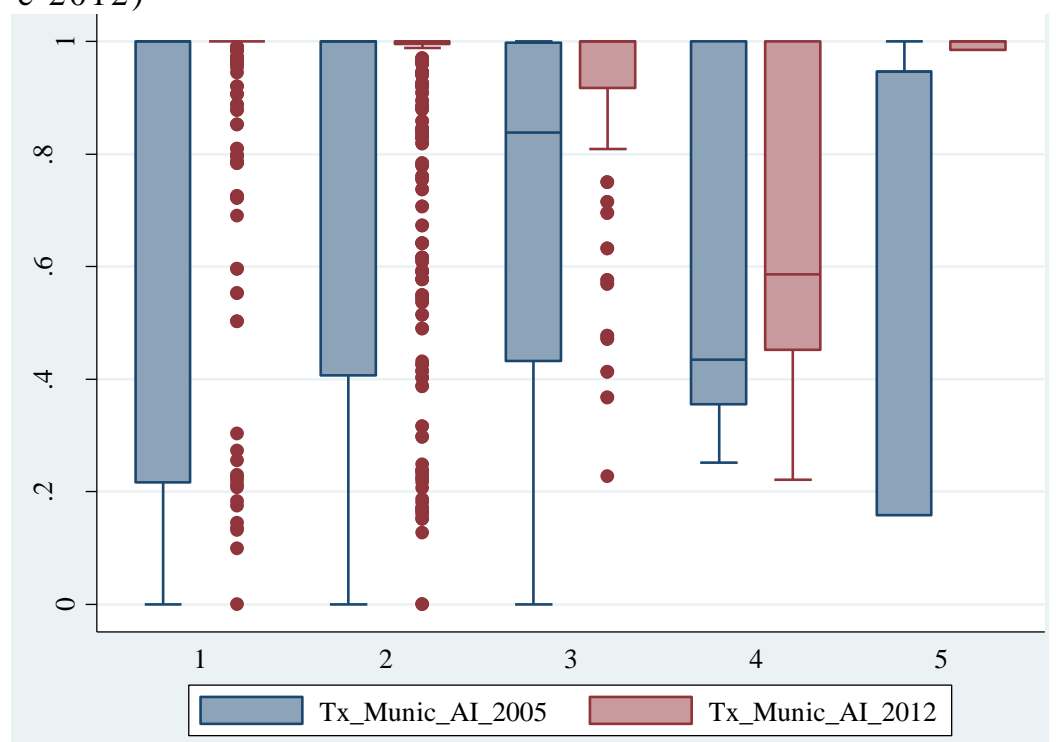

Fonte: IBGE, Censo 2010 e Fundação Seade. Tabulação e cálculos próprios 
Pode-se especular a causa da diferença no processo determinada pela renda das famílias: maior possibilidade de pressão pela aceleração do processo a partir de alguma percepção das famílias quanto à qualidade das escolas municipais e níveis de educação mais elevados da população em geral, possibilitando a existência de equipes técnicas com maior segurança para assumir redes escolares. Este trabalho não fará este tipo de análise, mas aponta essas possibilidades. Entretanto, faz-se a pergunta se seria a renda das famílias ou o nível educacional que poderia ser usado como variável para a suposição acima. A matriz de correlação apresentada abaixo mostra uma alta correlação entre duas dimensões, como era se esperar no contexto brasileiro, no qual o mercado de trabalho ainda paga um alto prêmio para níveis de educação mais elevados.

Tabela 14: Matriz de correlação entre PIB percapita municipal, renda das famílias e nível de educação dos residentes adultos

\begin{tabular}{lrrr}
\hline & $\begin{array}{r}\text { \% dos } \\
\text { PIB percapita }\end{array}$ & $\begin{array}{r}\text { domicílios com } \\
\text { renda acima de } \\
\text { 2SM }\end{array}$ & $\begin{array}{r}\text { Pessoas com } \\
\text { 25+ anos com } \\
\text { ES completo }\end{array}$ \\
\hline PIB percapita em 2010 & 1,0000 & & \\
\hline $\begin{array}{l}\text { \% dos domicílios com } \\
\text { renda acima de 2SM }\end{array}$ & 0,4896 & 1,0000 & \\
\hline $\begin{array}{l}\text { Pessoas com 25+ anos } \\
\text { com ES completo }\end{array}$ & 0,4363 & $\mathbf{0 , 9 5 6 3}$ & 1,0000 \\
\hline
\end{tabular}

Fonte: IBGE, Censo 2010. Cáculos e tabulação próprios.

\subsection{População e matrícula por dependência administrativa}

Diante de um contexto de descentralização e de aumento progressivo de atribuições do setor público em nível municipal para atender às demandas sociais mais amplas de seus habitantes, uma das análises comparativas entre contextos locais que precisam ser feitas é contrapor a cobertura de cada tipo de atendimento (universal, direcionada, temporária, etc.) de cada setor (saúde, habitação, segurança e educação) com a população alvo ou total de cada município, de forma a alcançar a dimensão dos desafios de atendimento social em cada localidade. Ou seja, é importante ter em mente que o tamanho da população do município e de sua rede importam para uma análise mais abrangente, porque as demandas dos diferentes grupos sociais e etários da população competem entre si. Em relação à educação básica, por ser um serviço público de caráter universal, complexo, de 
atendimento diário, contínuo e cumulativo por décadas, a dimensão da população é ainda mais relevante quando se analisa a cobertura, pois denota a dimensão do esforço empreendido pela entidade administrativa que o gerencia e, principalmente, que o financia.

Para se ter uma melhor ideia da evolução da cobertura, faz-se uma comparação dos históricos das matrículas na educação básica e da população-alvo (de 0 a $19 \operatorname{anos}^{56}$ ). Vemos que, depois de um pico no ano de 2000, o conjunto das coortes de 0-19 anos já diminuiu em mais de um milhão de pessoas até 2011, mas que ainda há uma parcela de quase dois milhões que não é atendida pela educação básica.

Gráfico 13: Evolução das matrículas totais da educação básica e da população total de 0 a 19 anos no Estado de São Paulo (1991, 1996, 2000-2011)

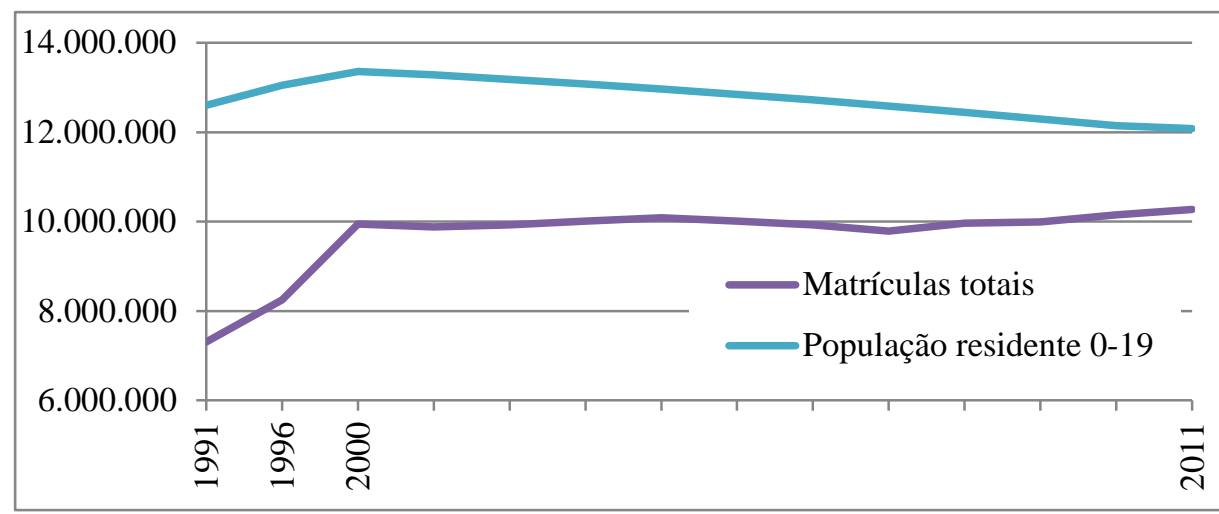

Fonte: IBGE, Censo 2010 e Fundação Seade. Tabulação e cálculo da autora

Ao se analisar os dados de frequência escolar por faixa etária, também obtidos do Censo IBGE 2010, percebe-se, que são as faixas das extremidades (creche e ensino médio) as que ainda precisam incorporar mais alunos, o que é compreensível pelo fato de só terem-se tornado obrigatórias a partir da Emenda Constitucional 59/2009, com período de graça até 2016. 
Tabela 15: Cobertura populacional da educação básica no Estado de São Paulo (2010)

\begin{tabular}{|l|r|r|r|r|r|r|}
\hline \multicolumn{7}{|c|}{ População residente por faixa etária (2010) } \\
\hline Estado de São Paulo & \multicolumn{1}{|c|}{ Total } & 0 a 4 anos & 5 a 9 anos & 10 a 14 anos & 15 a 17 anos & 18 ou 19 anos \\
\hline População residente & 41.262 .199 & 2.675 .372 & 2.860 .633 & 3.324 .913 & 1.990 .247 & 1.313 .661 \\
\hline Com frequência à escola & 12.332 .765 & 1.121 .361 & 2.763 .520 & 3.214 .344 & 1.697 .923 & 529.624 \\
\hline$\%$ & $30 \%$ & $42 \%$ & $97 \%$ & $97 \%$ & $85 \%$ & $40 \%$ \\
\hline
\end{tabular}

Fonte: IBGE, Censo 2010.

Em relação ao ensino fundamental especificamente, o histórico das matrículas totais desde 1991 mostra seu pico em 1996, uma baixa significativa desse ano para 2000 e depois um decréscimo das matrículas totais até 2011. Em relação à distribuição, percebe-se a expansão do espaço dos municípios no atendimento ao ensino fundamental ao longo do tempo.

Gráfico 14: Evolução da matrícula no ensino fundamental no Estado de São Paulo por dependência administrativa (1991, 1996, 2000-2011)

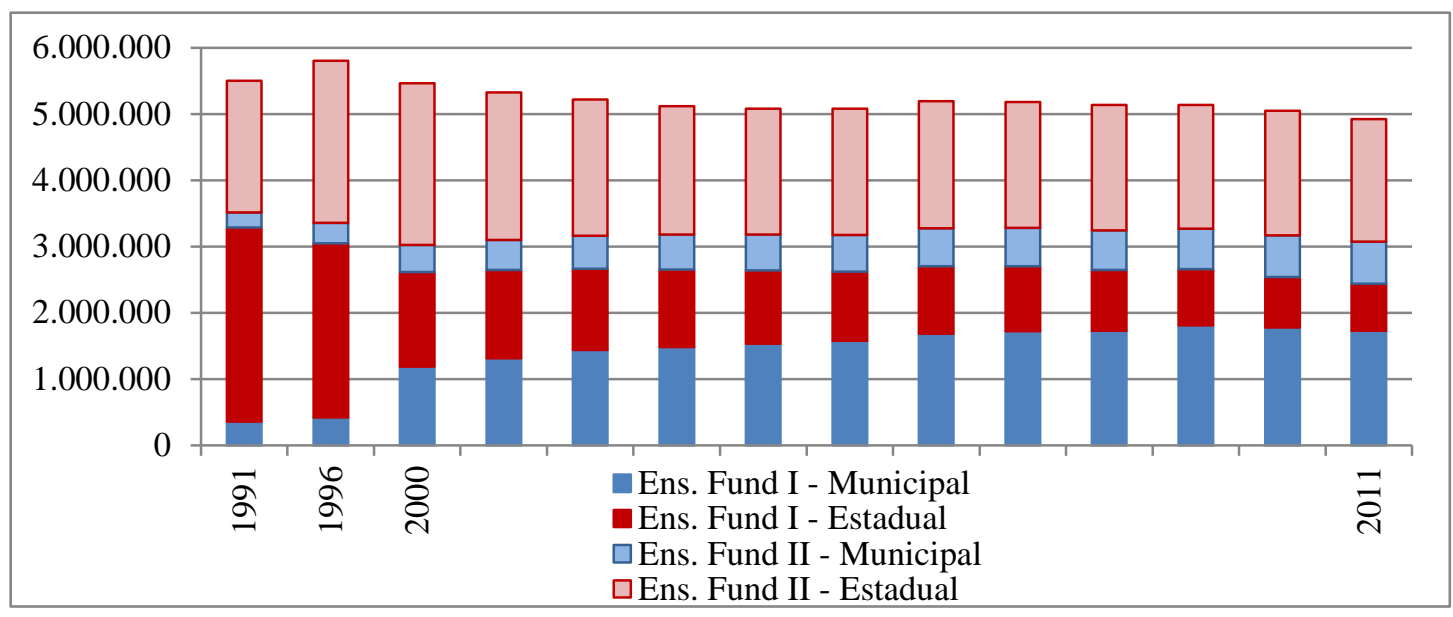

Fonte: Fundação SEADE. Tabulação própria.

Neste documento, a análise do tipo de município, no que toca a dimensão população, será feita com base na classificação do IBGE, que divide os municípios brasileiros por quantidade de residentes em sete níveis listados na tabela abaixo. Para facilitar as referências posteriores a eles, cada um recebeu um nome, também apresentado na tabela. A classificação numérica e os nomes foram mantidos para a análise da distribuição das matrículas, feita logo depois.

Ao se analisar, na tabela a seguir, a distribuição da população residente aferida pelo Censo IBGE de 2010, segundo as categorias identificadas por aquele órgão, identifica-se dois grupos opostos. $\mathrm{O}$ dos grandes municípios, com mais de 500.000 habitantes, que concentra $75 \%$ da população do estado, mas apenas $12 \%$ 
(75 localidades) do total deles, e o dos municípios com até 50.000 habitantes, que concentra mais de $80 \%$ do total de municípios, mas apenas $17 \%$ da população.

Tabela 16: Distribuição da população no Estado de São Paulo por patamar de população residente* nos municípios (2010)

\begin{tabular}{llrrrr}
\hline & $\begin{array}{l}\text { Categoria } \\
\text { de }\end{array}$ & & $\begin{array}{r}\text { População } \\
\text { residente } \\
\text { total }\end{array}$ & $\begin{array}{r}\% \text { dos } \\
\text { municípios }\end{array}$ & $\begin{array}{r}\% \text { da } \\
\text { população }\end{array}$ \\
\hline Até 5.000 & Nano & 157 & 511.179 & $24,3 \%$ & $1,2 \%$ \\
\hline De 5.001 a 10.000 & Micro & 122 & 862.776 & $18,9 \%$ & $2,1 \%$ \\
\hline De 10.001 a 20.000 & $\begin{array}{l}\text { Muito } \\
\text { pequenos }\end{array}$ & 122 & 1.749 .308 & $18,9 \%$ & $4,2 \%$ \\
\hline De 20.001 a 50.000 & Pequenos & 120 & 3.912 .702 & $18,6 \%$ & $9,5 \%$ \\
\hline De 50.001 a 100.000 & Médios & 49 & 3.402 .226 & $7,6 \%$ & $8,2 \%$ \\
\hline De 100.001 a 500.000 & Grandes & 66 & 13.338 .575 & $10,2 \%$ & $32,3 \%$ \\
\hline Mais de 500.000 & Metrópoles & 9 & 17.485 .433 & $1,4 \%$ & $42,4 \%$ \\
\hline Total no estado de SP & & 645 & 41.262 .199 & $100 \%$ & $100 \%$ \\
\hline
\end{tabular}

Fonte: IBGE, Censo 2010. Tabulação própria.

A mesma distribuição por categorias aplicada às matrículas do ensino fundamental apresentada abaixo mostra que $74 \%$ dos municípios operam redes educacionais com até 5.000 alunos e que apenas 14 municípios têm redes com contingentes discentes maiores que 50.000 .

Tabela 17: Distribuição das matrículas de ensino fundamental no Estado de São Paulo por patamar de matrículas nos municípios (2010)

\begin{tabular}{|c|c|c|c|c|c|}
\hline $\begin{array}{l}\text { Distribuição de } \\
\text { matrículas }\end{array}$ & $\begin{array}{l}\text { Categoria } \\
\text { de redes }\end{array}$ & Número & Alunos & $\begin{array}{r}\% \text { dos } \\
\text { municípios }\end{array}$ & $\begin{array}{r}\% \text { dos } \\
\text { alunos }\end{array}$ \\
\hline Até 5.000 & Nano & 475 & 365.519 & $73,6 \%$ & $12,3 \%$ \\
\hline De 5.001 a 10.000 & Micro & 72 & 252.851 & $11,2 \%$ & $8,5 \%$ \\
\hline De 10.001 a 20.000 & $\begin{array}{l}\text { Muito } \\
\text { pequenas }\end{array}$ & 44 & 308.950 & $6,8 \%$ & $10,4 \%$ \\
\hline De 20.001 a 50.000 & Pequenas & 39 & 648.641 & $6,0 \%$ & $21,9 \%$ \\
\hline De 50.001 a 100.000 & Médias & 10 & 345.100 & $1,6 \%$ & $11,6 \%$ \\
\hline De 100.001 a 500.000 & Grandes & 4 & 270.810 & $0,6 \%$ & $9,1 \%$ \\
\hline Mais de 500.000 & Metrópoles & 1 & 771.419 & $0,2 \%$ & $26,0 \%$ \\
\hline Total no estado de SP & & 645 & 2.963 .290 & $100 \%$ & $100 \%$ \\
\hline
\end{tabular}

Fonte: Fundação SEADE. Tabulação própria.

Levando-se em conta apenas os aspectos relacionados ao diferencial da baixa complexidade e à possibilidade de controle social, sempre lembrando do dilema descentralização $\mathrm{x}$ fragilidades técnicas, parece razoável alimentar a expectativa de que municípios com populações e com redes de ensino menores teriam maior possibilidade de oferecer serviços de educação pública de melhor qualidade a seus residentes. Precisamos saber, antes de mais nada, se os municípios menores são mais municipalizados que os maiores. Os gráficos a seguir, que seguem a mesma lógica temporal que os anteriores, mas agora 
mostram os municípios agrupados pelas categorias de município, mostram que embora todos os grupos de tamanho de municípios tenham aumentado substancialmente o percentual de matrículas municipalizadas desde o início do processo em 1996, os municípios maiores permaneceram com um nível mais baixo de municipalização que os menores.

Gráfico 15 A e B: Comparação da distribuição dos municípios pelo \% de municipalização nos anos iniciais com o tamanho de sua população (1996 e 2000)

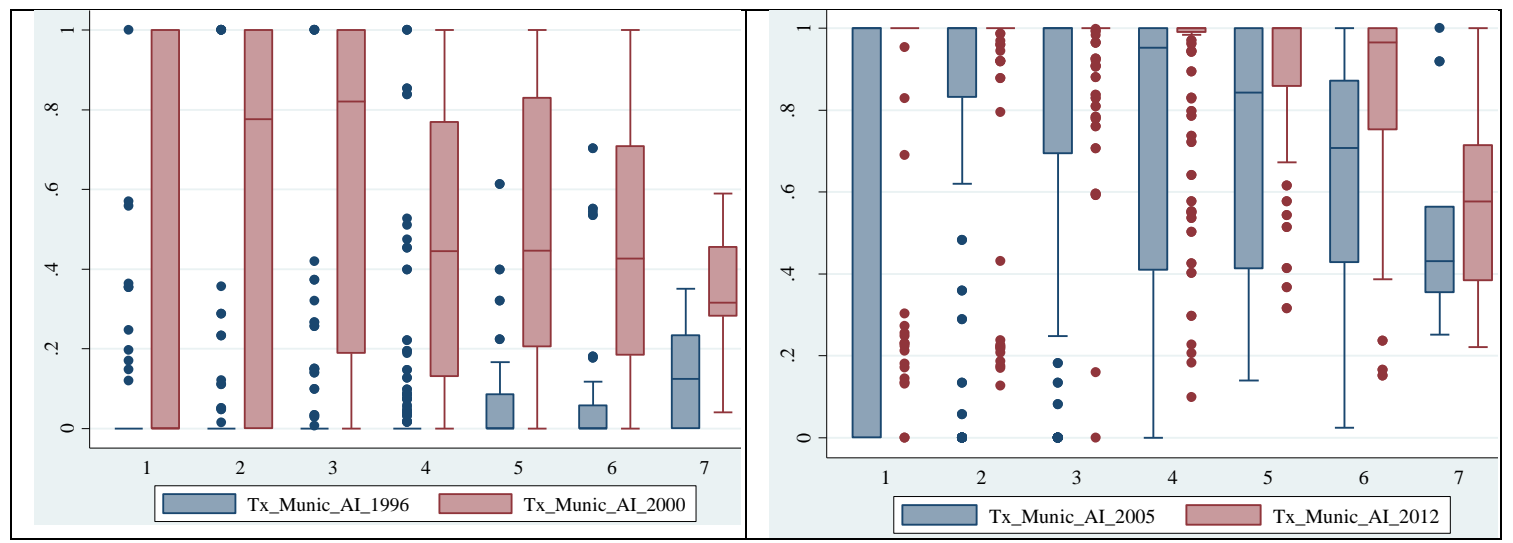

Fonte: IBGE, Censo 2010 e Fundação Seade. Tabulação e cálculos próprios

As análises preliminares desta sessão permitiram perceber que: a) os municípios absorveram as matrículas novas em ritmos diferentes, b) o nível de renda das famílias está relacionado com o aumento do nível de municipalização, c) o tamanho da população está relacionado com com um ritmo mais lento do mesmo processo e d) diferentes níveis de PIB percapita não apresentaram influência sistemática no ritmo de municipalização.

\subsection{Ritmo de evolução de desempenho por dependência administrativa}

Até aqui já vimos que a municipalização das matrículas é uma política pública de fato no Estado de São Paulo e que sua implementação está relacionada a, pelo menos, duas características dos municípios: renda das famílias e tamanho da população. Apesar de o processo de municipalização já estar quase concluído para a maior parte dos municípios, há um processo de transferência de matrículas ainda em andamento e conhecê-lo em maior detalhe pode ajudar a melhorá-lo para as etapas que restam, se houver interesse. 
Assim, parte-se para responder a segunda pergunta desta pesquisa, sobre desempenho comparado entre a rede estadual e as redes municipais.

Sobre a escolha dos indicadores de desempenho das redes, sabe-se que não é simples definir desempenho estudantil ou escolar, mas é uma decisão que já foi materializada em política pública no Brasil, com a criação do Sistema de Avaliação da Educação Básica (Saeb), que em 2005, foi universalizado para as séries finais de cada etapa do ensino fundamental ${ }^{57}$. O Brasil tem adotado a política de avaliação em massa desde os anos 1990 e já há uma quantidade expressiva de dados sobre alunos, escolas e seus contextos. Uma maneira de se aferir o desenvolvimento da educação é aplicando provas, em pequena ou em larga escala, de cunho autorregulado ou externo, mas sempre com critérios prédefinidos e instrumentos com graus responsáveis de metodologia confiável. Assumindo que esse é o caso do Brasil e que a Prova Brasil é um instrumento de avaliação em larga escala para o qual foram tomados cuidados que permitam fazer algumas comparações, vamos analizar o que esses dados apontam para a evolução da educação nos diferentes contextos de gestão no Estado de São Paulo. A evolução do aspecto desempenho das redes de ensino no Estado de São Paulo será comparada pelo Ideb municipal de cada rede conforme divulgado ${ }^{58}$ pelo Instituto Nacional de Estudos Pedagógicos (Inep) por município.

O Índice de Desenvolvimento da Educação Básica (Ideb) foi criado em 2007 pelo Ministério da Educação para facilitar o entendimento da população sobre a evolução da qualidade da educação, medida pelo desempenho dos alunos nas provas padronizadas de Língua Portuguesa e de Matemática, associado ao fluxo de alunos entre os anos escolares. Esta combinação de parâmetros procura evitar que os agentes dos sistemas educacionais (professores, escolas, municípios

\footnotetext{
57 Portaria 931 do MEC de março de 2005. Art $1^{\circ} \S 2$ : A Avaliação Nacional do Rendimento no Ensino Escolar - ANRESC tem os seguintes objetivos gerais: a) avaliar a qualidade do ensino ministrado nas escolas, de forma que cada unidade escolar receba o resultado global;

b) contribuir para o desenvolvimento, em todos os níveis educativos, de uma cultura avaliativa que estimule a melhoria dos padrões de qualidade e eqüidade da educação brasileira e adequados controles sociais de seus resultados;

c) concorrer para a melhoria da qualidade de ensino, redução das desigualdades e a democratização da gestão do ensino público nos estabelecimentos oficiais, em consonância com as metas e políticas estabelecidas pelas diretrizes da educação nacional;

d) oportunizar informações sistemáticas sobre as unidades escolares. Tais informações serão úteis para a escolha dos gestores da rede a qual pertençam.

58 http://portal.inep.gov.br/web/portal-ideb/planilhas-para-download
} 
e estados) aumentem suas médias por meio da retenção de alunos, o que é uma tradição no ensino brasileiro, conforme já apresentado. As fórmulas de cálculo estão apresentadas abaixo.

Gráfico 16: Fórmula de cálculo do IDEB

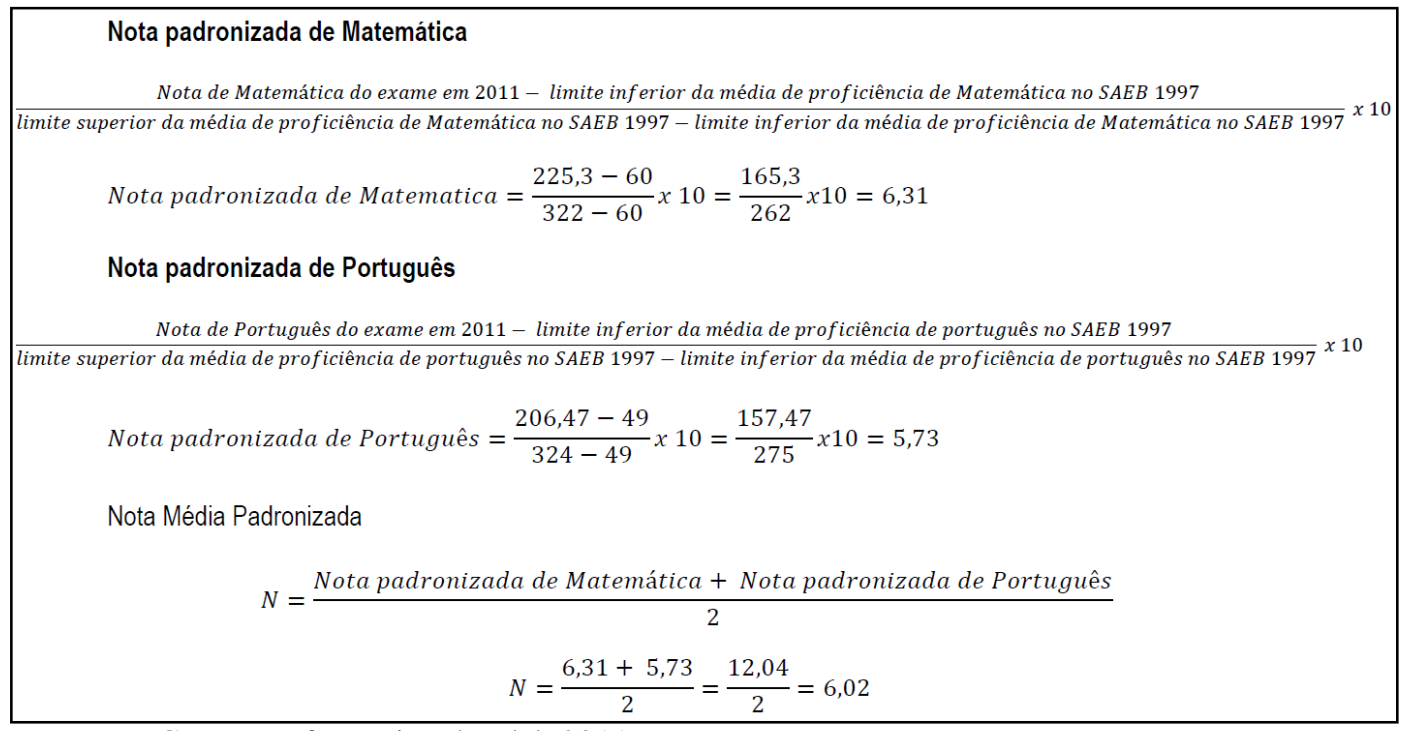

Fonte: MEC. Nota Informativa do Ideb 2011

O sistema está amarrado de tal forma que o Fundef/b estimula as prefeituras a matricularem todos os alunos, a divulgação do Ideb só é feita se, pelo menos $50 \%$ dos alunos matriculados nas séries das provas de cada unidade escolar e município realmente fizerem as avaliações ${ }^{59}$, e o indicador combina a média na prova com o percentual de alunos que progrediram para as séries seguintes, inibindo o expediente de se reter alunos para melhorar o desempenho das escolas e redes.

Apesar do desenho mais sofisticado, há um ponto importante a ser levantado a respeito do Ideb, que é seu potencial político. A forma como é apresentado, em uma escala de 0-10 e com metas bi-anuais de evolução, permitiu que o indicador rapidamente se tornasse uma referência fora do âmbito técnico da gestão da educação e alcaçasse a grande imprensa, por exemplo. Muitas vezes, é percebido como a verdade final a respeito da qualidade da educação de escolas, municípios e 
estados, mesmo com suas limitações intrínsecas. Neste capítulo o indicador fará parte de algumas comparações preliminares.

Nos gráficos a seguir, onde se apresenta a distribuição dos Idebs da rede estadual e das redes municipais por município, vemos que ambas as redes vêm melhorando o indicador nas sucessivas versões da Prova Brasil, exame de onde se extrai a média de proficiência que compõe o indicador. Na comparação dos dados, pode-se depreender que a sua evolução para a rede estadual parece ser muito próxima à do conjunto das redes municipais. A diferença está no fato de os municípios apresentarem uma dispersão ligeiramente maior.

Gráfico 17: Evolução Ideb - $5^{\circ}$ ano - Rede estadual (2) e redes municipais (2)

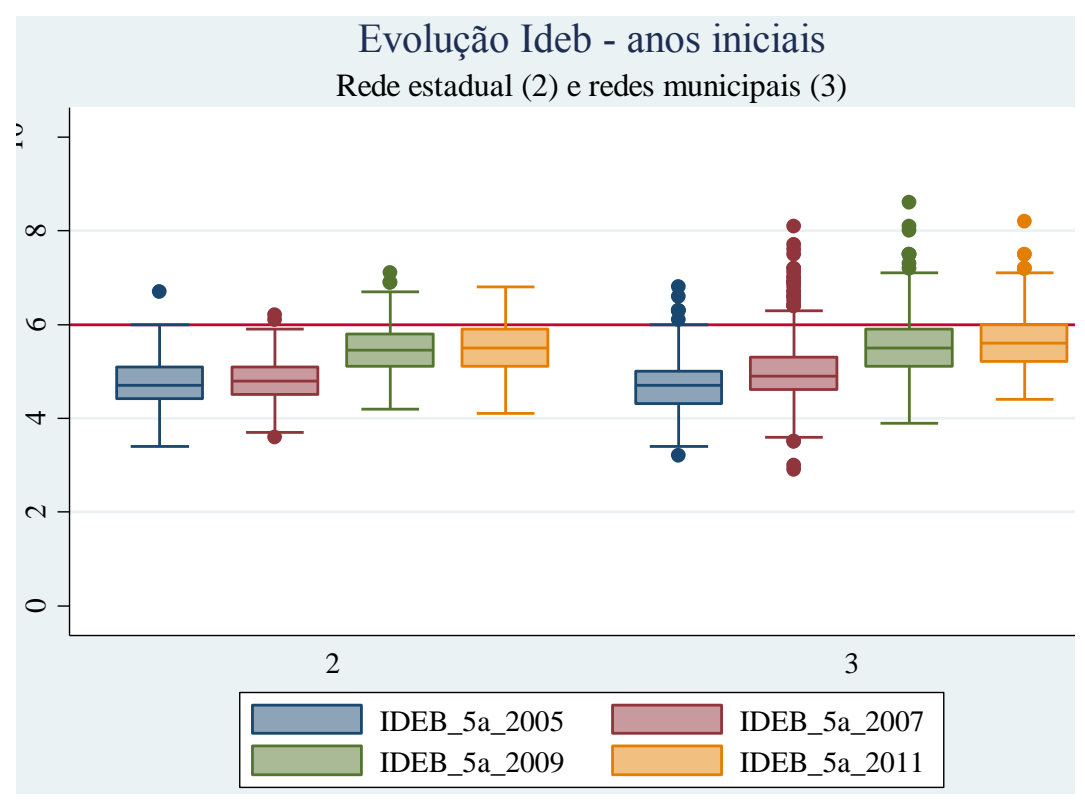

Fonte: INEP. Cálculos e tabulação próprios.

A diferença na dispersão dos dados é apresentada na tabela a seguir, na qual se constata médias próximas, mas desvios padrão maiores para os municípios $($ Rede $=3)$ que para o estado $(\operatorname{Rede}=2)^{60}$.

60 Os valores apresentados nesta sessão são exatamente os divulgados pelo INEP nas planilhas de Ideb e média de proficiência acumulados em todas as edições da Prova Brasil. Entretanto, há uma diferença entre as planilha que reportam os dados da Rede Estadual por município e as que reportam os mesmos dados, mas por escola. Nessas últimas não há registro de dados por escola para o ano de 2005, apresentados mais adiante nesta mesma sessão. Os dados existentes serão apresentados da mesma forma, com a indicação de que são inexistentes quando cabível, respeitando a credibilidade do órgão do MEC. 
Tabela 18: Sumário estatístico - evolução Ideb $5^{\circ}$ ano - rede estadual e redes municipais

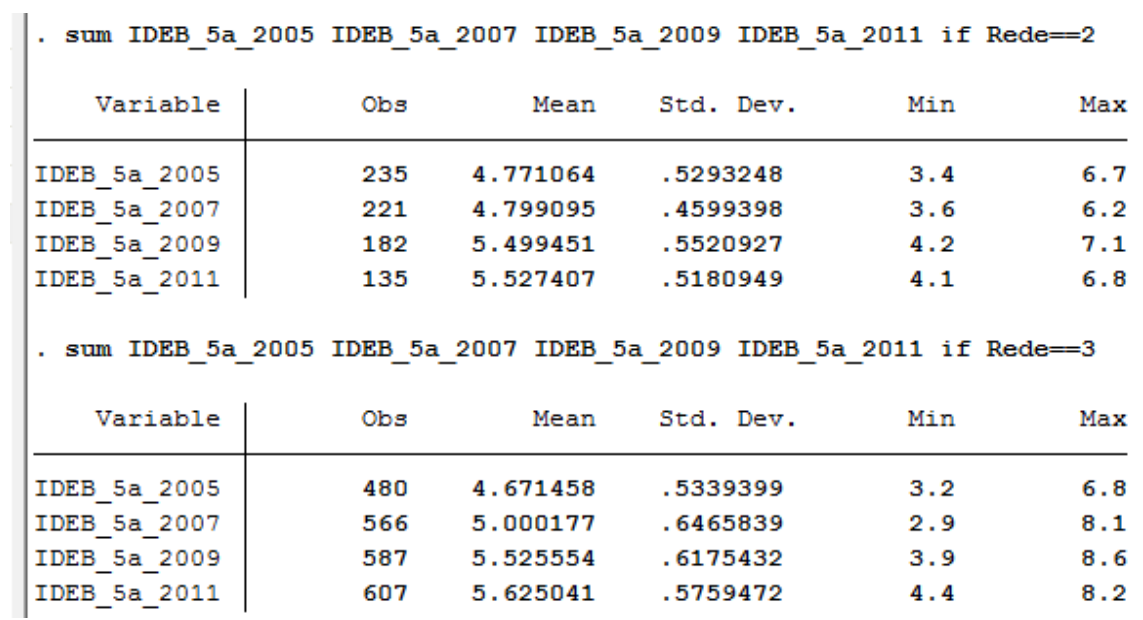

Fonte: INEP. Cálculos e tabulação próprios.

A mesma formatação dos dados para os anos finais do ensino fundamental mostra também uma evolução positiva do indicador nos dois tipos de rede, mas com uma maior acentuação e dispersão para o conjunto das redes municipais.

Gráfico 18: Evolução Ideb - $9^{\circ}$ Ano - Rede estadual (2) e redes municipais (2)

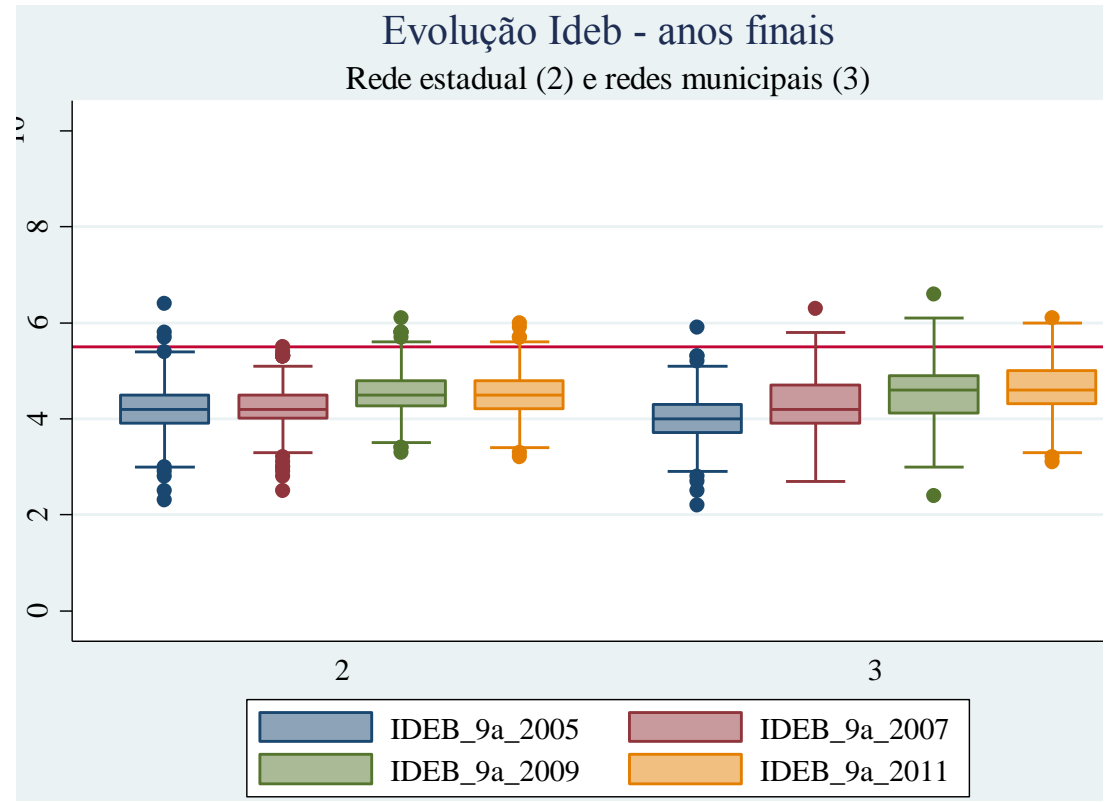

Fonte: INEP. Cálculos e tabulação próprios. 
Tabela 19: Sumário estatístico - evolução Ideb $5^{\circ}$ ano - rede estadual e redes municipais

\begin{tabular}{|r|rrrrr}
. sum IDEB_9a_2005 IDEB_9a_2007 & IDEB_9a_2009 & IDEB_9a_2011 if Rede = \\
Variable & Obs & Mean & Std. Dev. & Min & Max \\
\hline IDEB_9a_2005 & 523 & 4.151052 & .4914731 & 2.3 & 6.4 \\
IDEB_9a_2007 & 539 & 4.213544 & .4267347 & 2.5 & 5.5 \\
IDEB_9a_2009 & 528 & 4.519508 & .4150149 & 3.3 & 6.1 \\
IDEB_9a_2011 & 516 & 4.530233 & .4256996 & 3.2 & 6 \\
Sum IDEB_9a_2005 IDEB_9a_2007 IDEB_9a_2009 IDEB_9a_2011 if Rede $=3$ \\
Variable \\
\hline
\end{tabular}

Fonte: INEP. Cálculos e tabulação próprios.

Chama atenção uma primeira limitação do Ideb como referência do "esforço educacional" comparativo, seja entre municípios ou dependência administrativa. Embora a escala de valores do Ideb seja a mesma para as duas etapas do ensino fundamental, ela não tem o carater cumulativo que a escala das médias de proficiência de Língua Portuguesa e de Matemática. Assim, ao se comparar graficamente o comportamento do Ideb entre uma etapa e outra, pode-se ter a impressão equivocada de que há uma involução do aprendizado. Tanto assim, que a meta de longo prazo para o Ideb dos anos inciais é de 6,0 pontos e a dos anos finais é de 5,5 pontos $^{61}$.

Ainda procurando responder à pergunta 2, agora de forma mais detalhada, fez-se a mesma análise comparativa entre as redes, mas por nível de renda dos domicílios $^{62}$. Nota-se uma diferença bem maior na evolução do Ideb dos dois tipos de rede de ensino. O grupo das redes municipais apresenta uma evolução mais consistente e positiva que a rede estadual, em todos os níveis de renda, e há uma quantidade expressiva de municípios com Idebs acima da meta de 6,0, mesmo nos grupos de renda mais baixos (1 e 2).

$61 \mathrm{E}$ a do ensino médio é ainda mais baixa: 5,2 - http://ideb.inep.gov.br/resultado/

62 A classificação dos municípios por renda é explicada no capítulo a seguir 
Gráfico 19: Comparação da evolução do IDEB de $5^{\circ}$ ano na rede estadual com o conjunto das redes municipais por nível de renda domiciliar dos municípios

\section{Evolução do Ideb - anos iniciais}

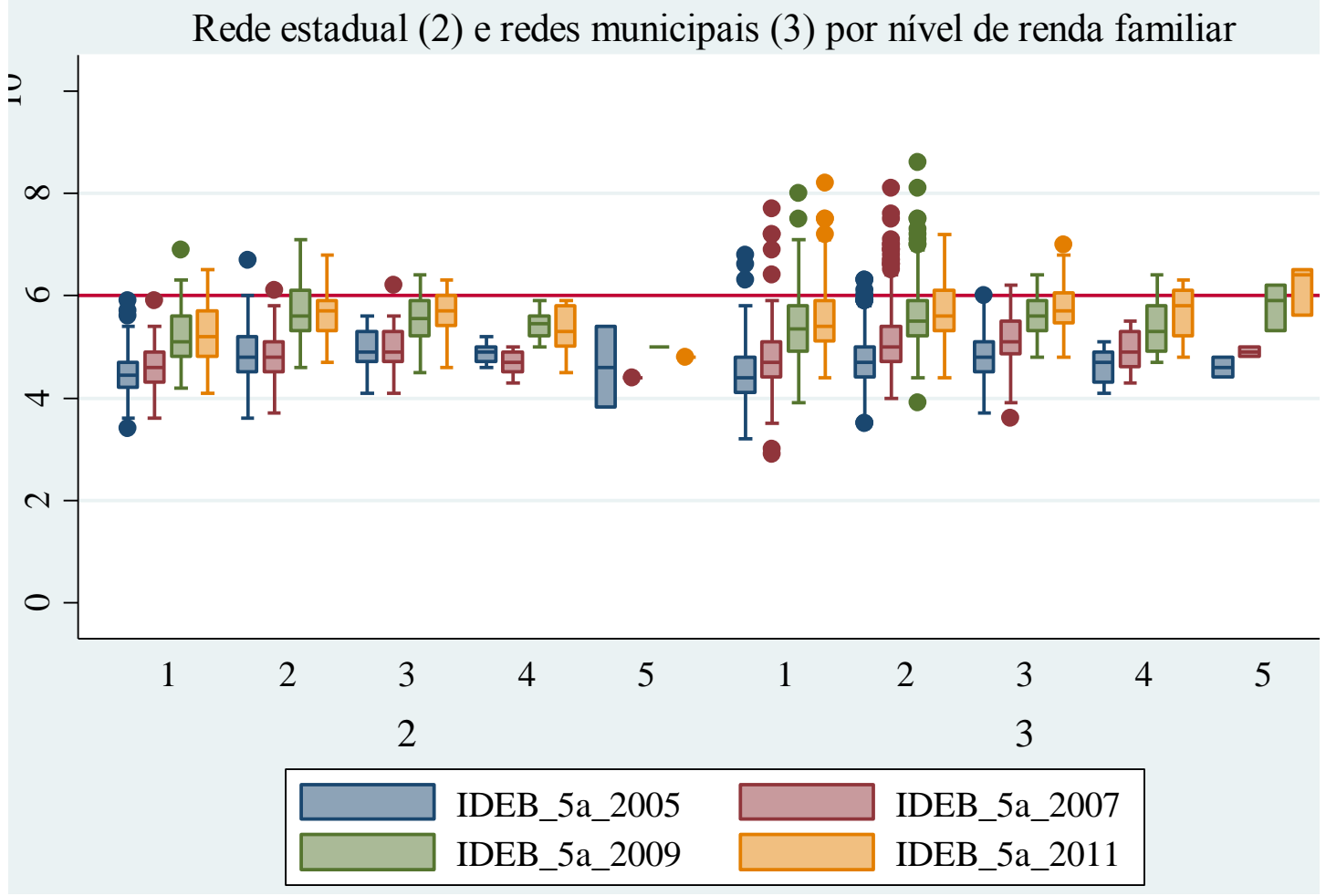

Fonte: INEP. Cálculos e tabulação próprios.

Estas observações podem parecer contraintuitivas, por duas razões: a primeira é que a rede estadual é administrada de forma central e as redes municipais, não. É como se a rede estadual tivesse demorado duas edições da Prova Brasil para começar a "acordar" e centenas de redes pulverizadas pelo estado estivessem mais alinhadas desde o início. E a segunda é que as redes municipais receberam no período de 2005 a 2012 uma quantidade substancial de alunos novos, tendo a maior parte deles passado a controlar $100 \%$ das matrículas. Além da responsabilidade de atender mais alunos, apenas em muito poucas cidades poderia se levantar, por exemplo, a hipótese de que foram os melhores alunos que migraram para a rede municipal, melhorando o indicador sem que tenha havido mudanças nas condições educativas das cidades.

É importante relembrar que há uma migração complementar que está em andamento no conjunto da educação básica do Estado de São Paulo. Mesmo com a melhoria dos indicadores das escolas estaduais e municipais, há uma crescente transferência de alunos para a rede particular ao longo do período analisado. 
Embora o fenômeno esteja presente nos cinco níveis de renda familiar dos domicílios, a proporção de alunos nas redes particulares obviamente é mais acentuado para os que contam com mais domicílios com renda mensal acima de dois salários mínimos. Mesmo assim, varia entre zero e 30\% nos níveis 2 e 3 e entre zero e $40 \%$ no grupo 5. Voltaremos a detalhar esse aspecto quando analisarmos os grupos de interesse particular no próximo capítulo, mas é importante não perder de vista que, se é razoável supor que os alunos que migram para a rede privada são os de maior renda e se esta renda, como vimos, está correlacionada com maior nível educacional, estão "sobrando" para as redes públicas alunos potencialmente com maior vulnerabilidade, o que valorizaria ainda mais a recente melhoria dos indicadores em nível municipal.

Gráfico 20: Evolução do percentual de matrículas nas redes particulares dos municípios por nível de renda dos domicílios

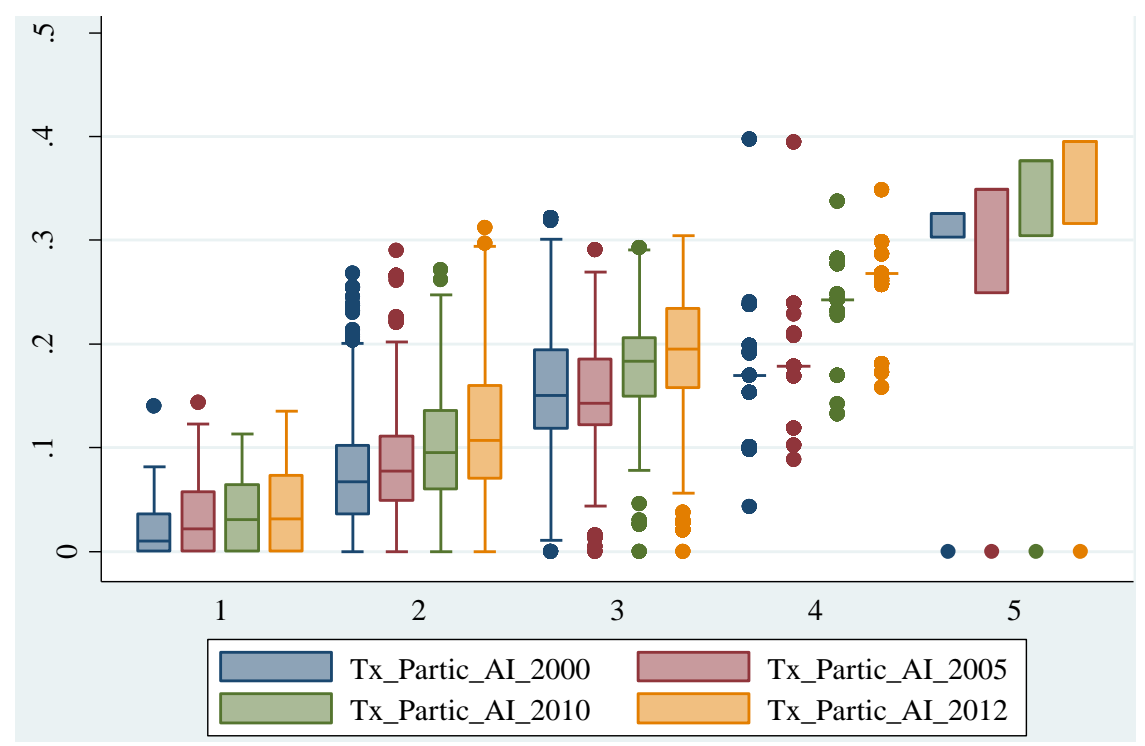

Fonte: Fundação Seade. Cálculos e tabulação próprios.

Como já se constatou uma tendência de aumento dos resultados nas sucessivas edições da Prova Brasil no Estado de São Paulo para as duas etapas do ensino fundamental, a análise de equidade entre as redes será feita apenas com os dados mais recentes, de 2011. Além disso, para poder comparar melhor a evolução entre as etapas de ensino, será utilizada a distribuição da proficiência média de cada escola em Língua Portuguesa, separada pelas categorias de renda familiar municipal, e não mais o Ideb. Observa-se o seguinte: a) para todas as 
categorias de renda, há uma proporção maior de escolas municipais com médias superiores a 200 pontos $^{63}$, que de escolas estaduais; b) embora a rede estadual seja uma só, comparada com o conjunto das redes municipais, há uma dispersão considerável dos resultados das escolas, mesmo dentro da mesma faixa de renda familiar, chegando a variar quase 100 pontos na categoria 4 (renda alta); c) a maior parte das escolas do estado mais rico da federação ainda não conseguiu alcançar uma média de proficiência considerada adequada ao final da primeira etapa do ensino fundamental ( $5^{\circ}$ ano $)$.

Gráfico 21: Média por escola de proficiência em Língua Portuguesa 2011 - por nível de renda familiar (de 1 a 5 ) e tipo de rede (2 ou 3)

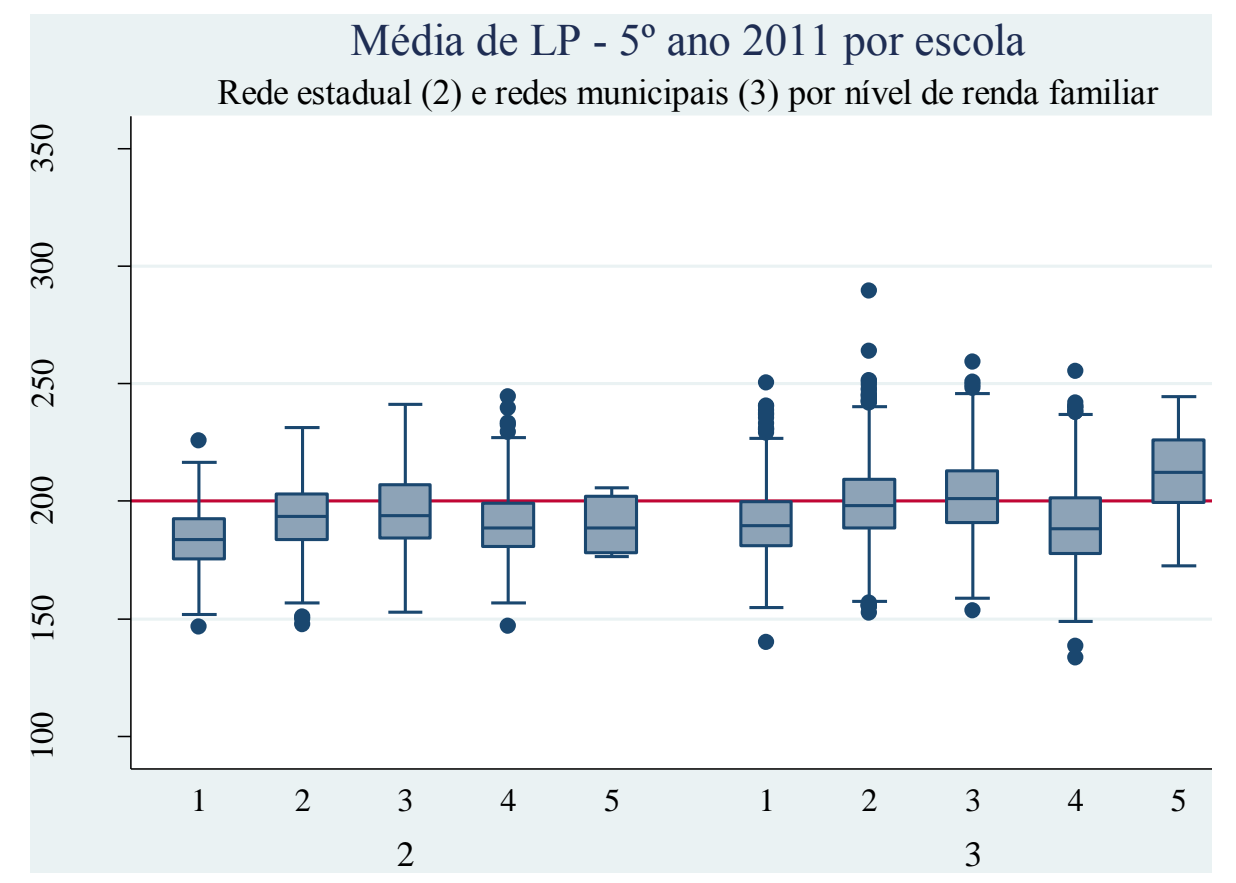

Fonte: Fonte: INEP e IBGE. Cálculos e tabulação próprios.

Para a segunda etapa do ensino fundamental a situação é ainda pior, com pouquíssimas escolas conseguindo chegar, em média, a 275 pontos, considerado patamar mínimo do nível adequado para o $9^{\circ}$ ano (entre 275 e 325 para Língua Portuguesa). Apenas no grupo das escolas municipais dos 3 municípios com renda Muito Alta (nível 5) mais de 25\% das escolas alcançam o nível adequado.

63 o Ministério da Educação não fixou faixas de proficiência por nível de desempenho, mas tampouco contesta as definições publicadas. Neste documento vai se utilizar como referência Soares, 2009, na qual apresentou as referências metodológicas para o SARESP, o qual utiliza a mesma escala do Saeb/Prova Brasil. A tabela completa com valores e níveis de proficiência está no Anexo. 
Gráfico 22: Média por escola de proficiência em Língua Portuguesa 2011 - por nível de renda familiar (de 1 a 5) e tipo de rede (2 ou 3)

Média de LP - $9^{\circ}$ ano 2011 por escola

Rede estadual (2) e redes municipais (3) por nível de renda familiar

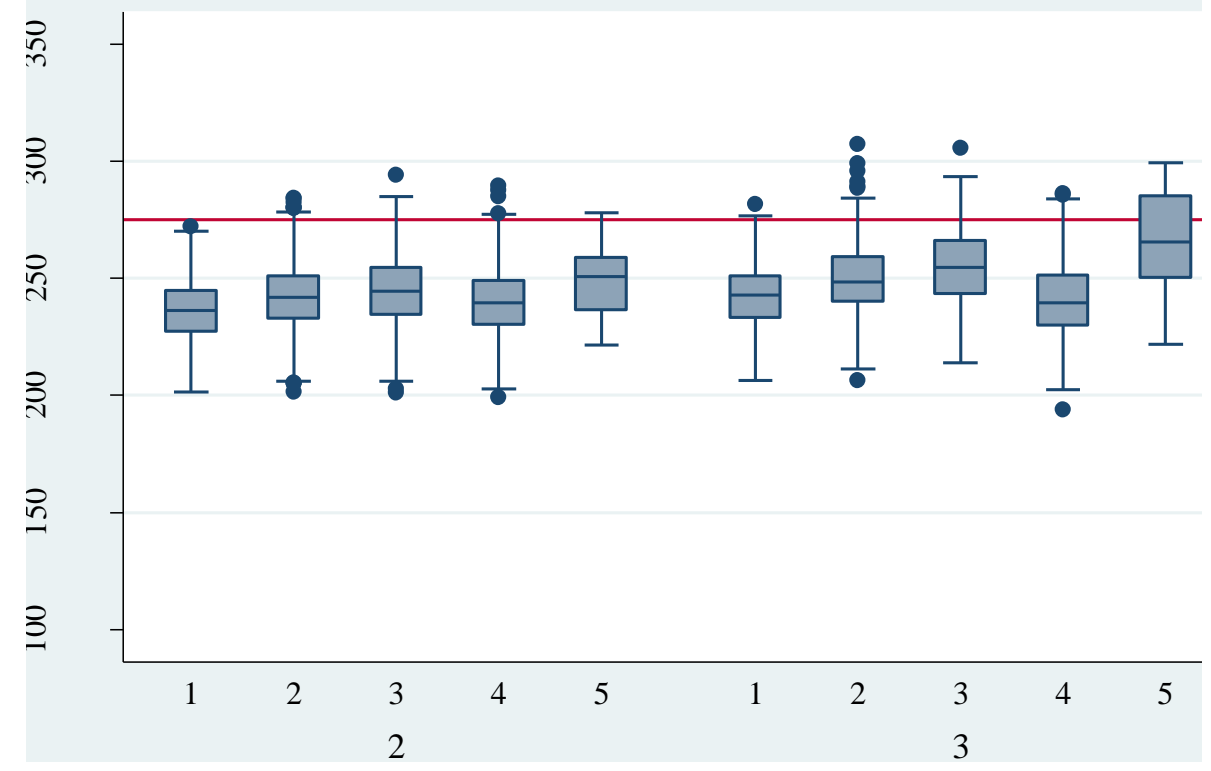

Mais uma comparação entre as redes, em termos de equidade é possível, pois com a regularidade da Prova Brasil já se pode observar a mesma coorte em pontos diferentes de sua tragetória escolar. É uma análise grosso modo porque os dados analisados não são os dos alunos, mas os das escolas. Há uma movimentação de alunos entre redes ao longo do tempo e provavelmente entre escolas de mesma rede. Mesmo levando-se em conta as limitações do que se pode concluir com a análise desse tipo de dado, o gráfico a seguir traz algumas contribuições interessantes.

Na rede estadual, a proporção de escolas que, em 2007, tinham média na faixa adequada para o $5^{\circ}$ ano (linha azul) é similar à que se verifica no $9^{\circ}$ ano (linha vermelha). No conjunto das escolas municipais, entretanto, a proporção parece diminuir do $5^{\circ}$ para o $9^{\circ}$ ano. Mesmo assim, há uma maior proporção de escolas municipais que alcança o nível adequado no $9^{\circ}$ ano que de escolas estaduais, lembrando que nesta etapa de ensino há muito mais escolas da rede do estado que das redes municipais. 
Gráfico 23: Evolução da média de proficiência em Língua Portuguesa por escola - mesma coorte - por nível de renda familiar (de 1 a 5) e tipo de rede (2 ou 3)

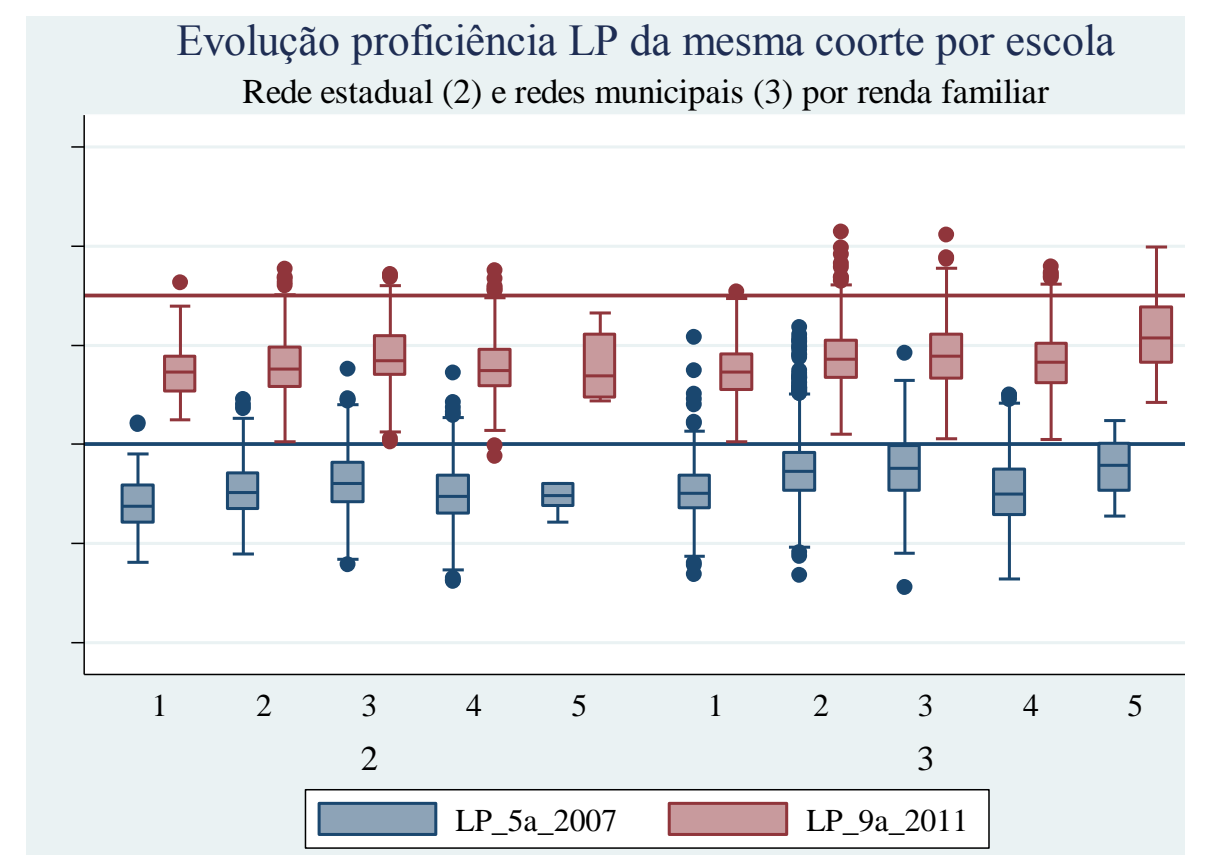

Uma última análise comparativa, apresentada nos gráficos a seguir, diz respeito à equidade e pode ser feita entre as redes com base na taxa de distorção idade-série por escola, disponibilizada pelo Inep ${ }^{64}$. Para os anos iniciais, a maior parte das escolas apresenta taxas de distorção idade-série abaixo de $15 \%{ }^{65}$. Mesmo assim, para o conjunto das escolas municipais, há um contingente substancial de escolas com taxas acima disso. Por volta de $21 \%$ delas, em todos os níveis de renda, exceto o nível 4 que apresenta uma proporção menor de escolas nessa situação.

Para os anos finais do ensino fundamental as escolas municipais apresentam maiores taxas de distorção em maior proporção que as estaduais. Nos dois gráficos, chama atenção que o nível 5 , de renda muito alta, apresente níveis de distorção alinhados com os municípios de nível de renda 1 e 2 (muito baixa e baixa). Para este caso, pode-se especular que, no nível de renda mais alta, a maior concentração de matrículas na rede privada deixa para a rede pública alunos com

$64 \mathrm{http}: / /$ portal.inep.gov.br/indicadores-educacionais

65 No relatório de acompanhamento do Education for all de 2012, sobre o tema de atraso escolar, a Unesco considera altas taxas de distorção acima de $15 \%$ nos anos iniciais do ensino fundametal (UNESCO, 2012, pg. 15) 
maior vulnerabilidade. Para a diferença sistemática de patamares de distorção entre as duas redes, a resposta poderia ser uma política mais consistente de progressão continuada na rede estadual. Nos gráficos a seguir os outliers (com taxas de distorção acima de $80 \%$ foram retirados do conjunto para facilitar a leitura do gráfico. Eles representam 0,08 nos anos iniciais e 0,11 nos anos finais e são em geral de escolas que fazem atendimento especial, como as que atendem alunos em conflito com a lei)

Gráfico 24: Taxa de distorção idade-série nos anos iniciais - por nível de renda familiar (de 1 a 5 ) e tipo de rede (2 ou 3 )

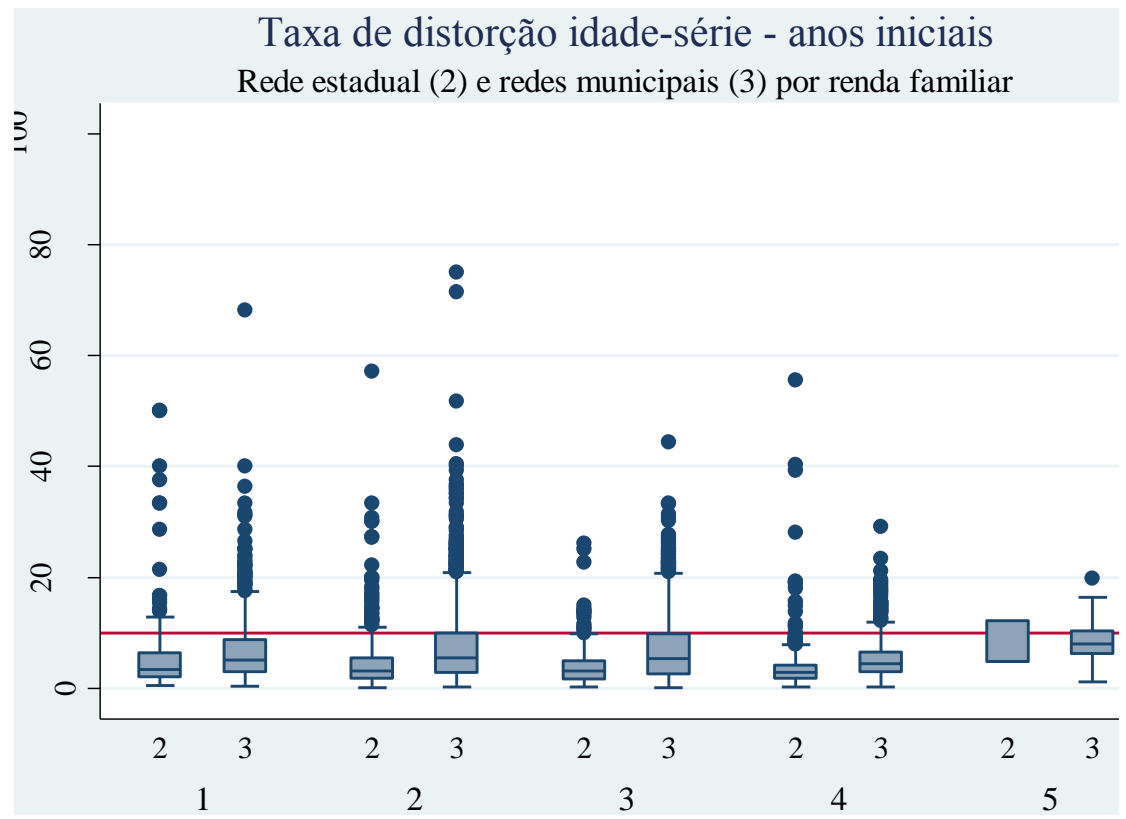

Gráfico 25: Taxa de distorção idade-série nos anos finais - por nível de renda familiar (de 1 a 5$)$ e tipo de rede (2 ou 3$)$

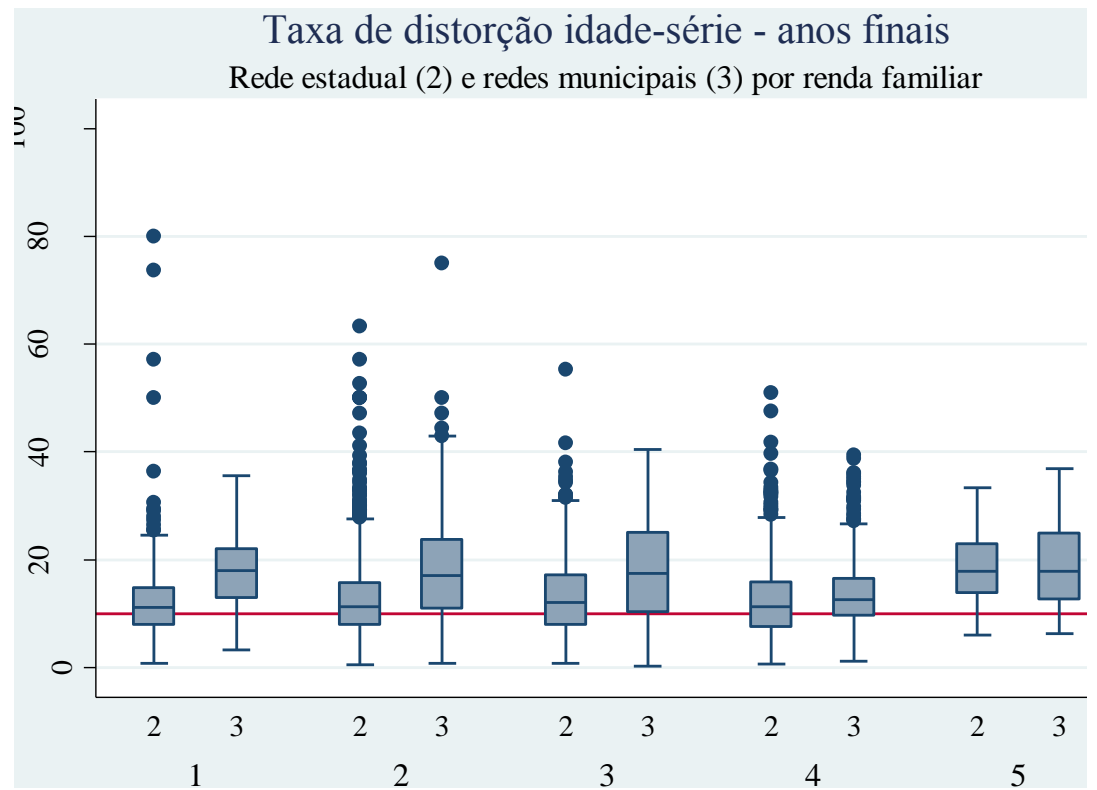


Esta sessão, que teve como objetivo responder à segunda pergunta da pesquisa: qual tipo de rede vem prestando melhor serviço à população em termos de educação no ensino fundamental, pudemos concluir que:

a) usando o Ideb como parâmetro, para os anos iniciais os municípios apresentam valores maiores em todas as edições da Prova Brasil, mas uma dispersão maior entre si. Para os anos finais, os valores do Ideb são muito próximos, mas a dispersão dos municípios é bem maior. É uma constatação que faz sentido porque estamos comparando uma rede centralizada em contexto municipal, com centenas de redes locais;

b) quando se compara a evolução do Ideb dos anos iniciais por nível de renda do município, percebe-se uma evolução mais consistente para os municípios, quando comparados à rede estadual, o que é contraintuitivo em relação à constatação acima;

c) o crescimento da migração para escolas privadas é uma realidade para todos os níveis de renda familiar, mas acentua-se à medida que o percentual de domicílios com renda acima de 2SM aumenta (do nível 1 para o nível 5)

d) quando se comparam os dados mais recentes de proficiência em Língua Portuguesa por escola com o nível de renda domiciliar, percebe-se que a relação não é muito clara para nem uma rede nem outra e que, para os anos finais do ensino fundamental a maior parte das escolas está longe de atingir os patamares considerados adequados para o $9^{\circ}$ ano

e) para uma mesma coorte, que fez a Prova Brasil no $5^{\circ}$ ano em 2007 e no $9^{\circ}$ ano em 2011, houve uma evolução positiva no período, mas caiu sensivelmente a proporção de escolas que atinge o patamar adequado no final do ensino fundamental

f) os dados de distorção idade-série são bem mais altos para a rede municipal que para a rede estadual, principalmente para a segunda etapa do ensino fundamental, e para nenhuma das redes isto não parece estar relacionado ao nível de renda do município. 


\section{Identificação de grupos similares de municípios}

\subsection{A construção das variáveis independentes}

Para responder às perguntas desta pesquisa procurou-se identificar variáveis que se relacionassem ao ritmo de municipalização e ao ritmo de evolução dos resultados educacionais no estado apresentados nos capítulos anteriores. Neste capítulo essas variáveis são apresentadas em maior detalhe, embora a relação com a evolução da municipalização e do desempenho já tenha sido abordada anteriormente em alguma medida. Foram selecionadas três características intrínsecamente relacionadas com o nível municipal e que, pelo menos intuitivamente, pudessem guardar relação com o desenvolvimento da educação. Em primeiro lugar, a dimensão produção de renda em nível local. A escolha dessa dimensão se deve à hipótese de que municípios com maior produção de renda local poderiam contar com mais recursos para a educação e que esses poderiam ter algum impacto no ritmo de municipalização ou de evolução de desempenho. Já vimos que não, mas a variável vai ser apresentada aqui, até para se tentar se compreender por quê.

Em segundo lugar, foi escolhida a dimensão renda das famílias, uma vez que nível de renda e de educação da família frequentemente estão relacionados à resultados educacionais, além de correlacionados entre si, como já foi mostrado.

A terceira dimensão foi geográfica, uma vez que o Estado de São Paulo estimula a interação intermunicipal em vários aspectos de interesse da gestão pública, inclusive na educação, por meio de sua divisão político-administrativa ${ }^{66}$.

66 Regiões administrativas e de governo: com o intuito de identificar conjuntos de cidades que compartilham características semelhantes, padrões de polarização e hierarquia funcional, o Poder Executivo do Governo do Estado de São Paulo estabeleceu a sua própria organização dos municípios. A primeira divisão regional foi estabelecida em 1967 através do Decreto $\mathrm{n}^{\circ}$ 48.162, com a criação de 11 regiões e 48 sub-regiões administrativas. Mais tarde, o Decreto $\mathrm{n}^{\circ}$ 22.970, de 29/11/1984, criou as 42 regiões de governo que conhecemos hoje. A compatibilização das duas estruturas (regiões administrativas e de governo) 
Em relação à produção de renda em nível local, o seguinte caminho foi seguido. A primeira opção para se fazer uma categorização que contribuísse para a diferenciação dos municípios foi utilizar um padrão internacional, uma vez que a mesma medida é utilizada mundialmente para se fazer comparações diversas entre países e regiões. O Banco Mundial ${ }^{67}$, que mantém bases de dados em nível global para um extenso número de variáveis, utiliza os seguintes parâmetros para classificar os países por nível de renda ${ }^{68}$ :

Tabela 20: Classificação de nível de renda do Banco Mundial traduzida para o contexto de São Paulo

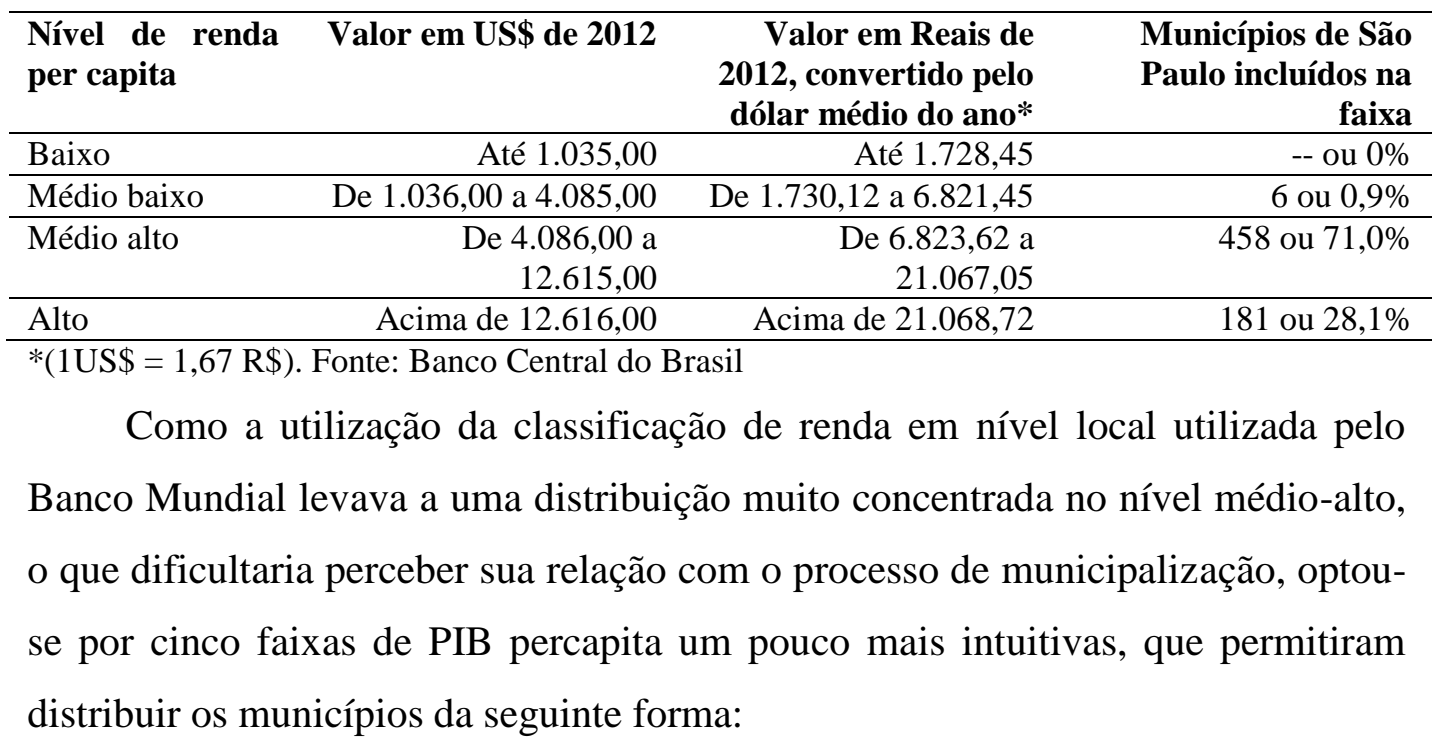

\footnotetext{
ocorreu com a publicação do Decreto n 26.581, em 1987, e com a criação das regiões administrativas Central, de Barretos e de Franca (Decreto n 32.141 , em 1990); Fonte: http://www.bibliotecavirtual.sp.gov.br/especial/201204-saopaulo.php\#territorio. Acesso em 5/11/2013

67 GDP per capita is gross domestic product divided by midyear population. GDP is the sum of gross value added by all resident producers in the economy plus any product taxes and minus any subsidies not included in the value of the products. It is calculated without making deductions for depreciation of fabricated assets or for depletion and degradation of natural resources. Data are in current U.S. dollars. Fonte: Banco Mundial, em : http://data.worldbank.org/indicator/NY.GDP.PCAP.CD. Acesso em 5/11/2013

68Income group: Economies are divided according to 2012 GNI per capita, calculated using the World. The groups are: low income, $\$ 1,035$ or less; lower middle income, $\$ 1,036$ - \$4,085; upper middle income, $\$ 4,086$ - \$12,615; and high income, $\$ 12,616$ or more. Fonte: Banco Mundial, How We Classify Countries, em: http://data.worldbank.org/about/country-classifications. Acesso em 5/11/2013
} 
Tabela 21: Categorias de PIB percapita e distribuição no Estado de São Paulo

\begin{tabular}{lrr}
\hline Categoria de PIB percapita & & \\
\hline (em Reais de 2010) & N & \multicolumn{1}{c}{$\%$} \\
\hline Até 10.000 & 71 & $11 \%$ \\
\hline De $10.001-20.000$ & 375 & $58 \%$ \\
\hline De $20.001-30.000$ & 116 & $18 \%$ \\
\hline De $30.001-40.000$ & 38 & $6 \%$ \\
\hline Acima de 40.001 & 45 & $7 \%$ \\
\hline Total & 645 & $100 \%$ \\
\hline
\end{tabular}

Como se viu no capítulo anterior, esse parâmetro não influenciou o ritmo de municipalização e, por isso, não foi usado para compreender melhor a evolução dos resultados, mas ficou a dúvida se haveria mesmo uma relação entre a produção de riqueza local e os gastos com educação e eles foram analisados mesmos assim. A primeira questão é que nas duas variáveis há outliers consideráveis que limitavam uma regressão, conforme tabela a seguir.

Tabela 22: Sumário estatístico despesa percapita na função educação no ensino fundamental e PIB percapita

\section{Sumário estatístico}

\begin{tabular}{|l|c|r|r|r|r|}
\hline Variável & N & \multicolumn{1}{c|}{ Média } & \multicolumn{1}{c}{ Desv. Padrão } & \multicolumn{1}{c|}{ Mín } & \multicolumn{1}{c|}{ Máx } \\
\hline $\begin{array}{l}\text { Despesa percapita em educação } \\
\text { EF (2011) }\end{array}$ & 618 & $8.117,95$ & $6.212,51$ & $1.704,63$ & $80.529,40$ \\
\hline PIB per capita municipal (2010) & 645 & $20.828,34$ & $18.306,29$ & $6.274,90$ & $239.950,80$ \\
\hline
\end{tabular}

Fonte: IBGE e Fundação Seade

Entretanto, verificou-se que para o PIB percapita $^{69} 95 \%$ dos dados se concentravam em valores até $\mathrm{R} \$ 50.000,00$ e para o gasto percapita na função educação no ensino fundamental ${ }^{70}, 95 \%$ dos dados se concentravam em valores até $\mathrm{R} \$ 15.000,00$. Esses limites foram então utilizados para produzir a seguinte regressão, que mostra praticamente nenhuma relação entre as duas variáveis. 
. regress DESP_Percap_2011 PIB_Perc_2010 if PIB_Perc_2010<=50000 \& DESP_Percap_2011<=15000

\begin{tabular}{r|rrr} 
Source & SS & df & MS \\
\hline $\begin{array}{r}\text { Model } \\
\text { Residual }\end{array}$ & 6263751.77 & 1 & 6263751.77 \\
& $2.4289 \mathrm{e}+09$ & 557 & 4360722.51 \\
\hline Total & $2.4352 \mathrm{e}+09$ & 558 & 4364132.95
\end{tabular}

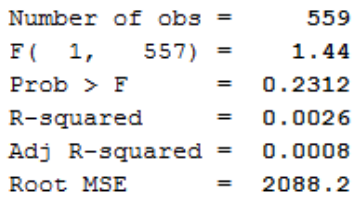

\begin{tabular}{r|rrrrrr}
\hline DESP_Per 2011 & Coef. & Std. Err. & $t$ & P $>|t|$ & [95\% Conf. Interval] \\
\hline PIB_Perc_2010 & .0138161 & .0115278 & 1.20 & 0.231 & -.0088272 & .0364594 \\
-cons & 6759.269 & 221.2901 & 30.54 & 0.000 & 6324.604 & 7193.934 \\
\hline
\end{tabular}

Partiu-se então para a segunda dimensão de análise, por renda das famílias. A distribuição percentual da população por classes de rendimento nominal mensal em frações de Salário Mínimo (SM) é uma informação obtida e calculada pelo IBGE nos censos decenais para o nível municipal. A tabela a seguir mostra a distribuição da população com 10 ou mais anos de idade pelas classes de rendimento no Estado de São Paulo.

Tabela 23: Distribuição da população residente com 10 anos ou mais por faixa de rendimento mensal nominal em Salários Mínimos

\begin{tabular}{|c|c|c|c|c|}
\hline $\begin{array}{l}\text { Classes de rendimento nominal } \\
\text { mensal (salário mínimo) (1) }\end{array}$ & $\begin{array}{c}\text { Pessoas de } 10 \text { anos } \\
\text { ou mais de idade }\end{array}$ & $\%$ & $\begin{array}{c}\text { \% acumulado } \\
0-1 \text { SM e acima de } \\
1 \text { SM }\end{array}$ & $\begin{array}{c}\% \text { acumulado } \\
0-2 \text { SM e acima de } \\
2 \text { SM }\end{array}$ \\
\hline Sem rendimento (2) & 12.494 .426 & $35,0 \%$ & \multirow[b]{3}{*}{$50,8 \%$} & \multirow[b]{4}{*}{$76,0 \%$} \\
\hline Até $1 / 2$ & 689.832 & $1,9 \%$ & & \\
\hline Mais de $1 / 2$ a 1 & 4.959 .173 & $13,9 \%$ & & \\
\hline Mais de 1 a 2 & 9.011 .607 & $25,2 \%$ & \multirow[b]{5}{*}{$49,2 \%$} & \\
\hline Mais de 2 a 5 & 5.924 .329 & $16,6 \%$ & & \\
\hline Mais de 5 a 10 & 1.806 .981 & $5,1 \%$ & & \\
\hline Mais de 10 a 20 & 606.998 & $1,7 \%$ & & \\
\hline Mais de 20 & 232.848 & $0,7 \%$ & & $24,0 \%$ \\
\hline Total & 35.726 .194 & $100,0 \%$ & $100,0 \%$ & $100,0 \%$ \\
\hline
\end{tabular}

Nota: (1) Salário mínimo utilizado: R\$ 510,00.

(2) Inclusive as pessoas que recebiam somente em benefícios.

Fonte: IBGE, Censo 2010

A tabela anterior mostra que pode-se grosso modo, dividir a população em dois grandes grupos: até $1 \mathrm{SM}(50,8 \%)$ e acima de $1 \mathrm{SM}(49,2 \%)$ de rendimento nominal mensal. Entretanto, para se poder classificar os municípios por um perfil discricionário de renda de seus residentes, optou-se por classificar os municípios pelas proporções de domicílios com renda acima de $2 \mathrm{SM}$, o que permitiria identificar, por exemplo, uma sistemática de opção por escola privada, feita por $21 \%$ dos estudantes (ou suas famílias). O ideal seria poder fazer a comparação fazendo o mesmo recorte que o Governo Federal faz para definir se um candidato pode participar de políticas públicas de compensnção no setor de educação como 
o Prouni, mas os dados já tabulados do IBGE não estão apresentados nesta forma. Assim, as categorias de renda familiar são as seguintes.

Tabela 24: Classificação e distribuição dos municípios pelo seu percentual de domicílios por faixa de rendimento mensal nominal em Salários Mínimos

\begin{tabular}{lllr}
$\begin{array}{l}\text { Perfil de renda } \\
\text { nominal domiciliar }\end{array}$ & $\begin{array}{c}\text { mensal } \\
\text { de 2SM }\end{array}$ & de domicílios acima & \% \\
\hline Muito baixa - 1 & De 0 a 10\% & 206 & $32 \%$ \\
\hline Baixa - 2 & De 11 a 20\% & 362 & $56 \%$ \\
\hline Média - 3 & De 21 a 30\% & 63 & $10 \%$ \\
\hline Alta - 4 & De 31 a 40\% & 11 & $2 \%$ \\
\hline Muito Alta - 5 & Acima de 41\% & 3 & $0 \%$ \\
\hline Total & & 645 & $100 \%$ \\
\hline
\end{tabular}

A terceira dimensão de análise é de cunho geográfico, pela distribuição político-administrativa do Governo do Estado de São Paulo. A Constituição Estadual, promulgada em outubro de 1989, em seu artigo 152 prevê que o estado seja subdividido em regiões, com os seguintes objetivos:

I - o planejamento regional para o desenvolvimento sócio-econômico e melhoria da qualidade de vida;

II - a cooperação dos diferentes níveis de governo, mediante a descentralização, articulação e integração de seus órgãos e entidades da administração direta e indireta com atuação na região, visando ao máximo aproveitamento dos recursos públicos a ela destinados;

III - a utilização racional do território, dos recursos naturais, culturais e a proteção do meio ambiente, mediante o controle da implantação dos empreendimentos públicos e privados na região;

IV - a integração do planejamento e da execução de funções públicas de interesse comum aos entes públicos atuantes na região;

V - a redução das desigualdades sociais e regionais.

Os artigos 154 a 156 mostram que essa divisão regional é operacionalizada e institucionalizada com coordenação conjunta com os municípios e apoio dos órgãos centrais do Governo Estadual. Cada setor de interesse (saúde, segurança, bacias hidrográficas, educação, etc.) é coordenado pela Secretaria de Estado correspondente. É de se esperar, portanto, que haja grupos de municípios 
diferentes entre si dentro do estado, obedecendo essa segmentação intencional. Para cada área de atuação do Governo Estadual há um tipo de reorganização dos municípios. As páginas a seguir mostram a subdivisão administrativa, por Região Administrativa e de Governo e a da área da educação, coordenada pela Secretaria de Educação, cuja divisão é feita em Diretorias de Ensino. Entretanto, como no caso da Educação houve uma desvinculação intencional entre a Secretaria de Estado da Educação e os municípios, dando a eles autonomia para gerir o setor em nível local, a divisão que será utilizada para a análise do processo de descentralização será a da Região Administrativa e não das Diretorias de Ensino, que tratam das escolas que permaneceram sob o controle do estado. Os mapas com as duas lógicas de segmentação do estado estão no Anexo.

A seguir apresenta-se alguns dados básicos para esse terceiro tipo de análise de perfil de municípios. A população do estado está dividida da seguinte forma em relação às Regiões Administrativas:

Tabela 25: Classificação e distribuição dos municípios e população pelas Regiões Administrativas do Estado

\begin{tabular}{lrrrr}
\hline Região Administrativa & $\begin{array}{l}\text { População } \\
\text { residente (2010) }\end{array}$ & $\mathbf{\%}$ & $\mathbf{N}$ & \% \\
\hline Total & 41.262 .199 & $100,0 \%$ & 645 & $100,0 \%$ \\
\hline R. Metrop. Baixada Santista & 1.664 .136 & $4,0 \%$ & 9 & $1,4 \%$ \\
\hline R. Metrop. Campinas & 2.749 .336 & $6,7 \%$ & 19 & $2,9 \%$ \\
\hline R. Metrop. São Paulo & 19.683 .975 & $47,7 \%$ & 39 & $6,0 \%$ \\
\hline R. Metrop. V. Paraiba e Lit. Norte & 2.264 .594 & $5,5 \%$ & 39 & $6,0 \%$ \\
\hline Central & 952.269 & $2,3 \%$ & 26 & $4,0 \%$ \\
\hline Araçatuba & 737.116 & $1,8 \%$ & 43 & $6,7 \%$ \\
\hline Barretos & 419.587 & $1,0 \%$ & 19 & $2,9 \%$ \\
\hline Bauru & 1.053 .258 & $2,6 \%$ & 39 & $6,0 \%$ \\
\hline Campinas sem RMC & 3.452 .048 & $8,4 \%$ & 71 & $11,0 \%$ \\
\hline Franca & 706.283 & $1,7 \%$ & 23 & $3,6 \%$ \\
\hline Marília & 940.814 & $2,3 \%$ & 51 & $7,9 \%$ \\
\hline Pres. Prudente & 834.135 & $2,0 \%$ & 53 & $8,2 \%$ \\
\hline Registro & 269.267 & $0,7 \%$ & 14 & $2,2 \%$ \\
\hline Ribeirão Preto & 1.247 .761 & $3,0 \%$ & 25 & $3,9 \%$ \\
\hline S. J. Rio Preto & 1.483 .594 & $3,6 \%$ & 96 & $14,9 \%$ \\
\hline Sorocaba & 2.804 .026 & $6,8 \%$ & 79 & $12,2 \%$ \\
\hline Fon Fon
\end{tabular}

Fonte: Fundação Seade e IBGE. Tabulação e cálculos próprios

A tabela a seguir, com dados de matrícula de 2012, mostra o seguinte em relação ao processo de municipalização: 
a) há 9 Reg. Administrativas com taxa de municipalização acima de $75 \%$ nos anos iniciais, mas apenas uma com todos os municípios controlando $100 \%$ das matrículas, a Região de Barretos. Nessa região 37\% dos municípios também controlam totalmente as matrículas nos anos finais.

b) há mais três Reg. Administrativas com perfil semelhante ao da Região de Barretos, a Região Metropolitana do Vale do Paraíba e Litoral Norte, com 85\% e $36 \%$ dos municípios com a matrícula totalmente municipalizada em cada etapa e duas regiões contíguas à de Barretos: Franca $(83 \%$ e $48 \%)$ e Ribeirão Preto $(88 \%$ e $36 \%)$.

c) há apenas duas regiões que contam com menos de $50 \%$ dos municípios controlando totalmente as matrículas nos anos iniciais, a Região Metropolitana de São Paulo e a de Santos, nessas, menos de $10 \%$ dos municípios controlam as matrículas nos anos finais.

Tabela 26: Distribuição percentual dos municípios pelas Regiões Administrativas do estado por nível de municipalização 


\begin{tabular}{|c|c|c|c|c|c|c|c|}
\hline Região administrativa & Código & Etapa & $0-25 \%$ & $26-50 \%$ & $51-75 \%$ & $76-99 \%$ & $100 \%$ \\
\hline \multirow[t]{2}{*}{ Reg. Metrop. São Paulo } & 1 & Anos iniciais & $8 \%$ & $13 \%$ & $15 \%$ & $26 \%$ & $38 \%$ \\
\hline & & Anos finais & $85 \%$ & $3 \%$ & $5 \%$ & $0 \%$ & $8 \%$ \\
\hline \multirow[t]{2}{*}{ Reg. Metrop. Campinas } & 2 & Anos iniciais & $11 \%$ & $5 \%$ & $0 \%$ & $11 \%$ & $74 \%$ \\
\hline & & Anos finais & $53 \%$ & $5 \%$ & $16 \%$ & $5 \%$ & $21 \%$ \\
\hline \multirow[t]{2}{*}{ Reg. Metrop. Baix. Santista } & 17 & Anos iniciais & $0 \%$ & $0 \%$ & $11 \%$ & $56 \%$ & $33 \%$ \\
\hline & & Anos finais & $22 \%$ & $22 \%$ & $44 \%$ & $11 \%$ & $0 \%$ \\
\hline \multirow[t]{2}{*}{ Reg. Metrop. V. Paraíba e L. Norte } & 16 & Anos iniciais & $0 \%$ & $5 \%$ & $0 \%$ & $10 \%$ & $85 \%$ \\
\hline & & Anos finais & $33 \%$ & $13 \%$ & $3 \%$ & $15 \%$ & $36 \%$ \\
\hline \multirow[t]{2}{*}{ Central } & 3 & Anos iniciais & $8 \%$ & $15 \%$ & $4 \%$ & $4 \%$ & $69 \%$ \\
\hline & & Anos finais & $50 \%$ & $15 \%$ & $4 \%$ & $8 \%$ & $23 \%$ \\
\hline \multirow[t]{2}{*}{ Araçatuba } & 4 & Anos iniciais & $2 \%$ & $0 \%$ & $0 \%$ & $7 \%$ & $91 \%$ \\
\hline & & Anos finais & $88 \%$ & $0 \%$ & $0 \%$ & $2 \%$ & $9 \%$ \\
\hline \multirow[t]{2}{*}{ Barretos } & 5 & Anos iniciais & $0 \%$ & $0 \%$ & $0 \%$ & $0 \%$ & $100 \%$ \\
\hline & & Anos finais & $58 \%$ & $0 \%$ & $0 \%$ & $5 \%$ & $37 \%$ \\
\hline \multirow[t]{2}{*}{ Bauru } & 6 & Anos iniciais & $8 \%$ & $5 \%$ & $3 \%$ & $5 \%$ & $79 \%$ \\
\hline & & Anos finais & $87 \%$ & $3 \%$ & $3 \%$ & $0 \%$ & $5 \%$ \\
\hline \multirow[t]{2}{*}{ Campinas sem RMC } & 7 & Anos iniciais & $4 \%$ & $1 \%$ & $7 \%$ & $18 \%$ & $69 \%$ \\
\hline & & Anos finais & $61 \%$ & $10 \%$ & $8 \%$ & $3 \%$ & $18 \%$ \\
\hline \multirow[t]{2}{*}{ Franca } & 8 & Anos iniciais & $4 \%$ & $0 \%$ & $4 \%$ & $9 \%$ & $83 \%$ \\
\hline & & Anos finais & $48 \%$ & $4 \%$ & $0 \%$ & $0 \%$ & $48 \%$ \\
\hline \multirow[t]{2}{*}{ Marília } & 9 & Anos iniciais & $10 \%$ & $4 \%$ & $10 \%$ & $0 \%$ & $76 \%$ \\
\hline & & Anos finais & $92 \%$ & $0 \%$ & $0 \%$ & $2 \%$ & $6 \%$ \\
\hline \multirow[t]{2}{*}{ Presidente Prudente } & 10 & Anos iniciais & $2 \%$ & $2 \%$ & $4 \%$ & $8 \%$ & $85 \%$ \\
\hline & & Anos finais & $77 \%$ & $4 \%$ & $2 \%$ & $0 \%$ & $17 \%$ \\
\hline \multirow[t]{2}{*}{ Registro } & 11 & Anos iniciais & $0 \%$ & $0 \%$ & $0 \%$ & $43 \%$ & $57 \%$ \\
\hline & & Anos finais & $93 \%$ & $0 \%$ & $7 \%$ & $0 \%$ & $0 \%$ \\
\hline \multirow[t]{2}{*}{ Ribeirão Preto } & 12 & Anos iniciais & $0 \%$ & $4 \%$ & $0 \%$ & $8 \%$ & $88 \%$ \\
\hline & & Anos finais & $36 \%$ & $16 \%$ & $8 \%$ & $4 \%$ & $36 \%$ \\
\hline \multirow[t]{2}{*}{ Sorocaba } & 14 & Anos iniciais & $4 \%$ & $0 \%$ & $5 \%$ & $19 \%$ & $72 \%$ \\
\hline & & Anos finais & $57 \%$ & $0 \%$ & $5 \%$ & $6 \%$ & $25 \%$ \\
\hline \multirow[t]{2}{*}{ São José do Rio Preto } & 15 & Anos iniciais & $9 \%$ & $1 \%$ & $1 \%$ & $4 \%$ & $84 \%$ \\
\hline & & & $71 \%$ & $6 \%$ & $3 \%$ & $4 \%$ & $16 \%$ \\
\hline
\end{tabular}

Os gráficos a seguir mostram o processo de municipalização dos anos iniciais do ensino fundamental em dois momentos, no início, em 1996, e na situação mais atual, em 2012. Com a ajuda da tabela anterior é possível identificar algumas situações dignas de nota:

RA da Baixada Santista - 17: era a com maior percentual de municípios com matrículas municipais em 1996, mas não chegou a completar o processo em 2012, embora a maior parte dos municípios dessa região ainda esteja finalizando o processo (56\%). A RA de Barretos - 5, que em 1996 só contava com um município com rede local foi a única que completou o processo em todos os 19 municípios, com 37\% deles já controlando também os anos finais. Embora claramente haja diferenças nos ritmos de descentralização entre as RAs, todas aderiram ao processo de descentralização desde o início e continuam absorvendo 
matrículas, muitas delas, inclusive, também para os anos finais do ensino fundamental.

Gráfico 26 A e B: Comparação da taxa de municipalização por RA - início (1996) e dado mais recente do processo de municipalização (2012)
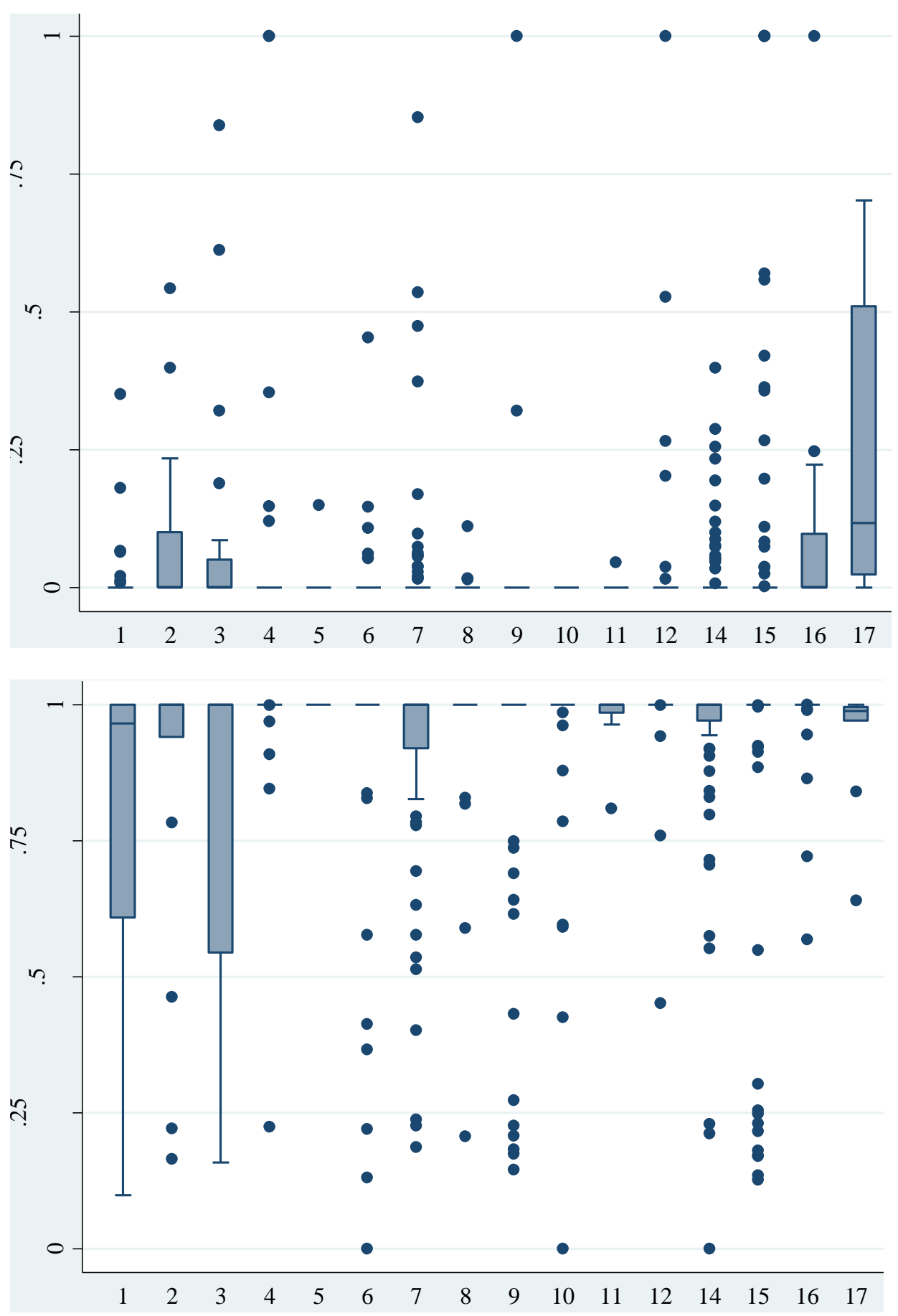

Fonte: Fundação Seade. Tabulação e cálculos próprios

A partir dessas análises iniciais, foi possível perceber a existência de pelo menos quatro grupos de interesse para terem seus processos de municipalização e seus resultados observados com mais detalhe: 
a) os que têm $100 \%$ das matrículas sob controle municipal nas duas etapas (121 municípios), ou seja, o grupo das prefeituras que apostaram na descentralização - GRUPO 1;

b) os que têm menos de $25 \%$ das matrículas sob controle municipal nos anos iniciais (35 municípios), ou seja, o dos que não apostaram na municipalização - GRUPO 2;

c) a Região Administrativa de Barretos, com 19 municípios, a única que tem $100 \%$ deles municipalizados nos anos iniciais, mas nem todos nos anos finais (portanto, diferente do GRUPO 1) - GRUPO 3 e

d) os 52 municípios que desde o início da universalização da Prova Brasil apresentaram médias em Língua Portuguesa acima de 200 pontos GRUPO 4 


\section{Análise dos grupos identificados}

Os quatro grupos identificados como de interesse para uma investigação mais detalhada foram:

a) os que apostaram na municipalização, recebendo $100 \%$ das matrículas em ambas as etapas do ensino fundamental - GRUPO 1;

b) os que não apostaram nela e que têm menos de $25 \%$ das matrículas sob controle local - GRUPO 2;

c) os da Região Administrativa de Barretos, a única com 100\% das matrículas dos anos iniciais sob controle de seus municípios (e acelerando para os anos finais com sete já concluídos ${ }^{71}$ e nove que nem começaram ${ }^{72}$ em 2012) - GRUPO 3;

d) os municípios que, desde o início da Prova Brasil universalizada (a partir de 2005) tinham (e mantiveram em todas as outras edições) médias em Língua Portuguesa no $5^{\circ}$ ano acima de 200 pontos GRUPO 4.

A lista com os nomes dos municípios contidos em cada grupo está no Anexo. Esses grupos serão agora novamente analisados em relação à "velocidade" de municipalização no início e no final do processo (1996, 2000 e 2012), percentual mais recente de matrículas na rede privada para os anos iniciais e para a evolução da média de Língua Portuguesa nas duas etapas do ensino fundamental, mas agora em relação às suas escolas. Espera-se, com esses recortes, aprofundar a resposta às perguntas desta pesquisa tanto no que toca o processo de 
mudança na distribuição as matrículas no tempo, como no referente ao binômio qualidade-equidade.

\section{Transferência de matrícula}

Em primeiro lugar veremos como esses quatro grupos absorveram as matrículas municipais. O GRUPO 1 iniciou o processo de municipalização dos anos iniciais de forma "instantânea", tendo logo concluído a primeira etapa em 2000 para os níveis de renda 1, 4 e 5, que contam com um menor número de municípios. Para os anos finais, a adesão também foi imediata, mas com a conclusão dando-se mais recentemente, a não ser para os grupos 4 e 5 , que já estavam municipalizados nas duas etapas em 2000.

Gráfico 27 A e B: Evolução da taxa de municipalização por nível de renda - anos iniciais e anos finais - GRUPO 1

\section{Evolução da taxa de municipalização por nível de renda}

GRUPO 1 - anos iniciais

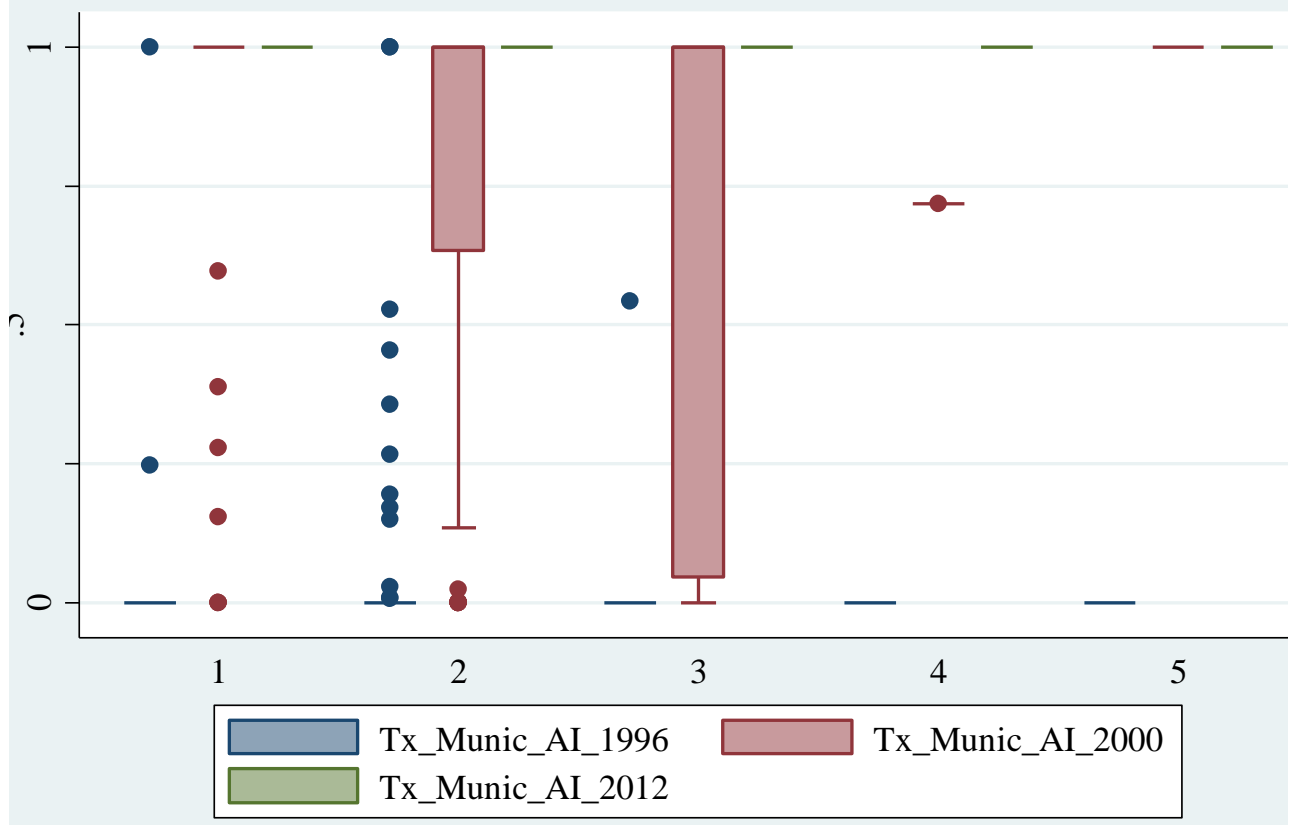




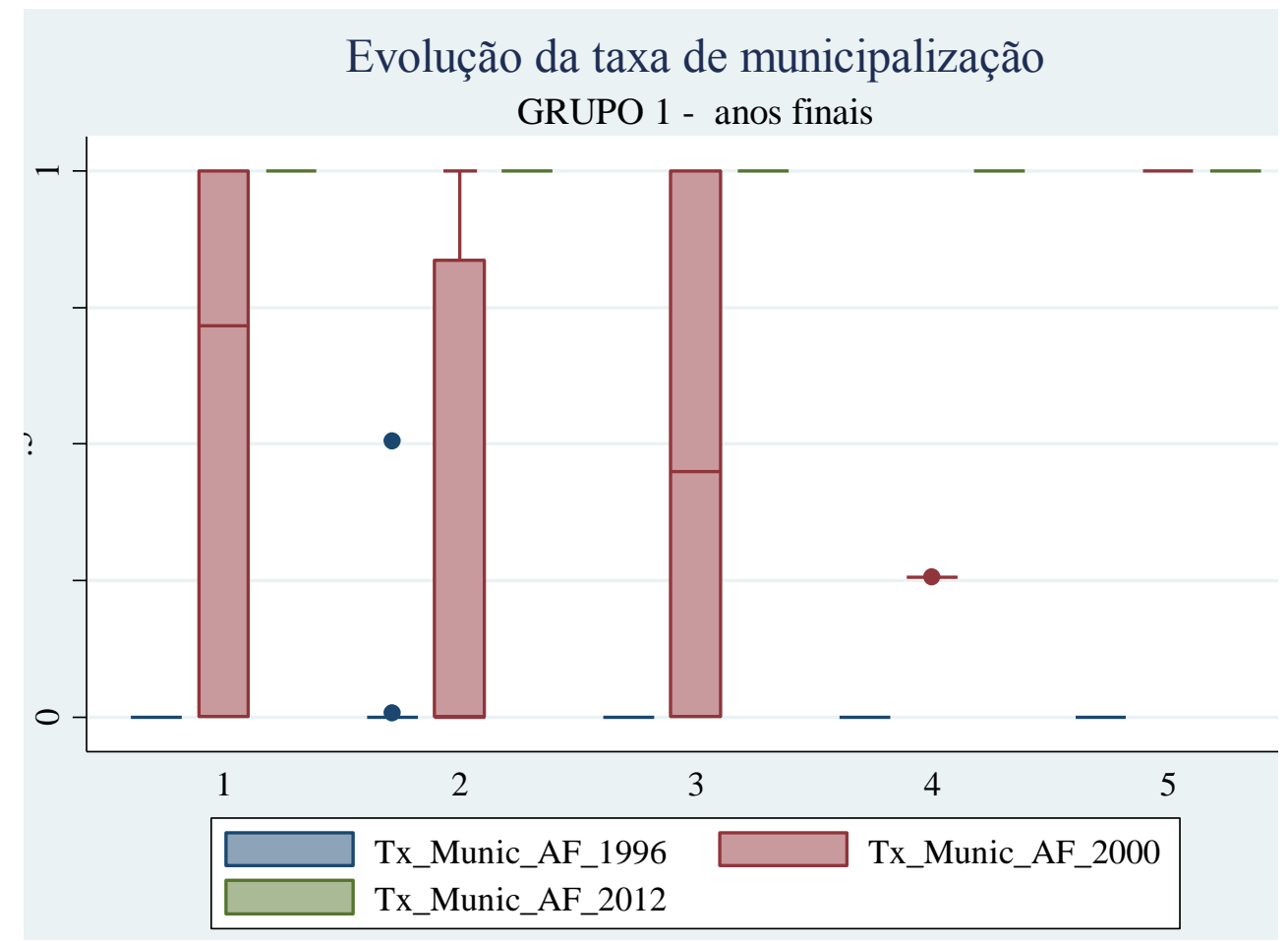

Fonte: Fundação Seade e IBGE. Tabulação e cálulos próprios

O GRUPO 3 - da RA de Barretos, e o GRUPO 4 não serão colocados em evidência aqui porque apresentaram processo análogo ao do GRUPO 1 (adesão imediata e conclusão rápida do processo), mesmo com, para os do GRUPO 3, seus municípios se concentrando nos níveis mais baixos de renda (entre os níveis 1 e $3)$.

O GRUPO 2, que não aderiu ao processo de forma clara, em 2012 parece também já ter iniciado um processo de absorção de matrículas. O nível de renda não parece estar relacionado com o processo. 
Gráfico 28: Evolução da taxa de municipalização por nível de renda - anos iniciaisGRUPO 2

Evolução da taxa de municipalização por nível de renda GRUPO 2 - anos iniciais

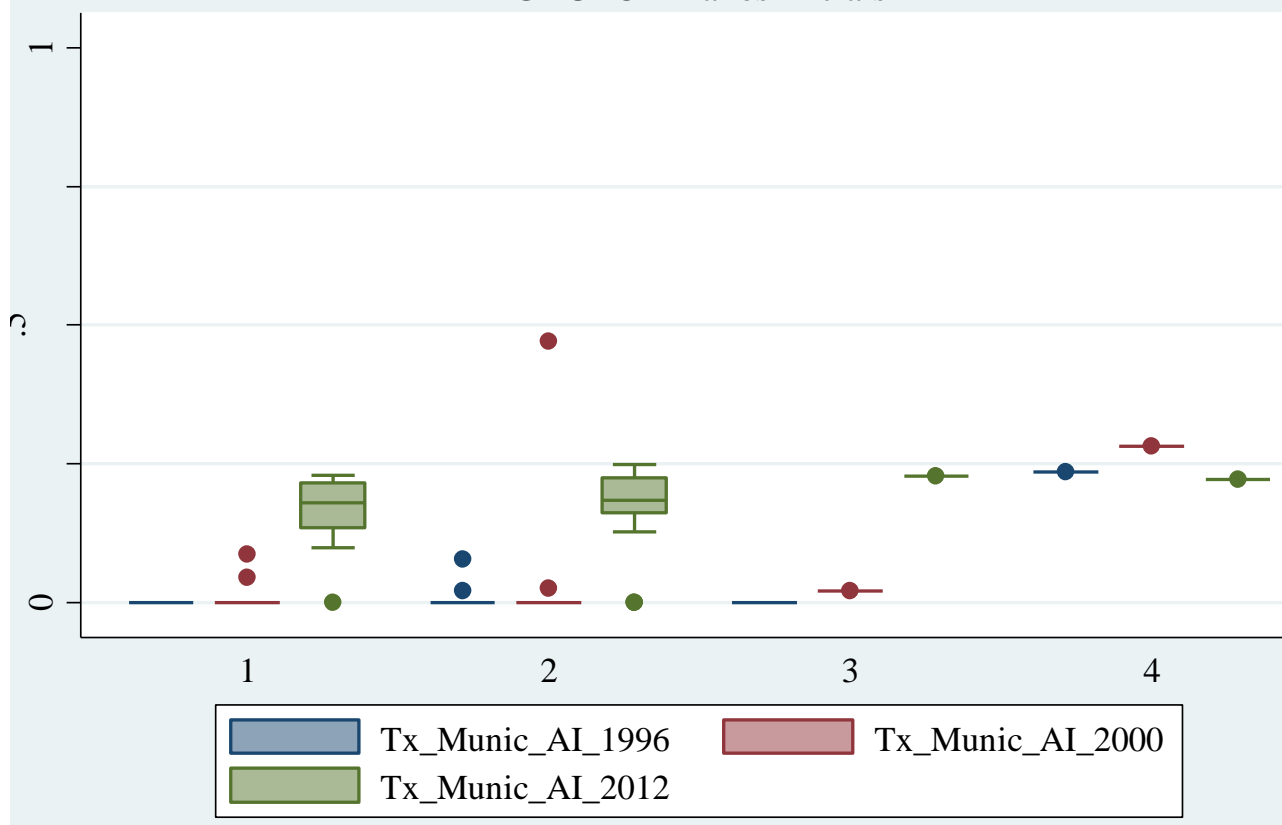

Fonte: Fundação Seade e IBGE. Tabulação e cálulos próprios

Em relação à transferência de matrículas para redes particulares, os GRUPOS foram analisados pelo percentual de matrículas em rede particular para o início do do processo de municipalização (1996) e para os dados mais recentes (2012), em cada uma das etapas do ensino fundamental. A tabela a seguir mostra o sumário estatístico das variáveis taxa de matrícula na rede particular, em primeiro lugar para o conjunto dos municípios do estado e depois para cada grupo de interesse. 
Tabela 27: Sumário estatístico - percentual de matrículas na rede particular - anos iniciais e finais em 1996 e em 2012

\begin{tabular}{|c|c|c|c|c|c|c|}
\hline & Variável & $\mathbf{N}$ & Média & Desv. Padrão & Mín & Máx \\
\hline \multirow{4}{*}{$\begin{array}{l}\text { Para todos } \\
\text { os } \\
\text { municípios }\end{array}$} & $\begin{array}{l}\text { Tx matrícula rede particular } \\
1996 \text { (anos iniciais) }\end{array}$ & 236 & $9,8 \%$ & $6,5 \%$ & $0,1 \%$ & $35,0 \%$ \\
\hline & $\begin{array}{l}\text { Tx matrícula rede particular } \\
2012 \text { (anos iniciais) }\end{array}$ & 335 & $12,6 \%$ & $7,2 \%$ & $0,4 \%$ & $39,5 \%$ \\
\hline & $\begin{array}{l}\text { Tx matrícula rede particular } \\
1996 \text { (anos finais) }\end{array}$ & 221 & $10,4 \%$ & $6,6 \%$ & $0,2 \%$ & $39,2 \%$ \\
\hline & $\begin{array}{l}\text { Tx matrícula rede particular } \\
2012 \text { (anos finais) } \\
\end{array}$ & 327 & $13,0 \%$ & $7,0 \%$ & $0,3 \%$ & $40,4 \%$ \\
\hline \multirow{4}{*}{ GRUPO1 } & $\begin{array}{l}\text { Tx matrícula rede particular } \\
1996 \text { (anos iniciais) }\end{array}$ & 25 & $9,0 \%$ & $6,6 \%$ & $1,4 \%$ & $24,9 \%$ \\
\hline & $\begin{array}{l}\text { Tx matrícula rede particular } \\
2012 \text { (anos iniciais) }\end{array}$ & 47 & $9,7 \%$ & $5,6 \%$ & $1,5 \%$ & $21,0 \%$ \\
\hline & $\begin{array}{l}\text { Tx matrícula rede particular } \\
1996 \text { (anos finais) }\end{array}$ & 23 & $9,5 \%$ & $6,0 \%$ & $1,3 \%$ & $21,0 \%$ \\
\hline & $\begin{array}{l}\text { Tx matrícula rede particular } \\
2012 \text { (anos finais) }\end{array}$ & 46 & $9,8 \%$ & $5,8 \%$ & $0,4 \%$ & $19,9 \%$ \\
\hline \multirow{4}{*}{ GRUPO 2} & $\begin{array}{l}\text { Tx matrícula rede particular } \\
1996 \text { (anos iniciais) }\end{array}$ & 9 & $6,3 \%$ & $4,6 \%$ & $1,6 \%$ & $15,0 \%$ \\
\hline & $\begin{array}{l}\text { Tx matrícula rede particular } \\
2012 \text { (anos iniciais) }\end{array}$ & 11 & $10,5 \%$ & $6,6 \%$ & $0,4 \%$ & $25,7 \%$ \\
\hline & $\begin{array}{l}\text { Tx matrícula rede particular } \\
1996 \text { (anos finais) }\end{array}$ & 7 & $7,7 \%$ & $5,6 \%$ & $1,6 \%$ & $16,6 \%$ \\
\hline & $\begin{array}{l}\text { Tx matrícula rede particular } \\
2012 \text { (anos finais) } \\
\end{array}$ & 10 & $9,7 \%$ & $5,6 \%$ & $1,6 \%$ & $19,6 \%$ \\
\hline \multirow{4}{*}{ GRUPO 3} & $\begin{array}{l}\text { Tx matrícula rede particular } \\
1996 \text { (anos iniciais) }\end{array}$ & 4 & $10,5 \%$ & $5,1 \%$ & $5,0 \%$ & $16,3 \%$ \\
\hline & $\begin{array}{l}\text { Tx matrícula rede particular } \\
2012 \text { (anos iniciais) }\end{array}$ & 7 & $14,5 \%$ & $5,2 \%$ & $8,6 \%$ & $23,0 \%$ \\
\hline & $\begin{array}{l}\text { Tx matrícula rede particular } \\
1996 \text { (anos finais) }\end{array}$ & 5 & $10,9 \%$ & $4,4 \%$ & $5,0 \%$ & $16,5 \%$ \\
\hline & $\begin{array}{l}\text { Tx matrícula rede particular } \\
2012 \text { (anos finais) }\end{array}$ & 7 & $15,9 \%$ & $6,0 \%$ & $7,9 \%$ & $23,7 \%$ \\
\hline \multirow{4}{*}{ GRUPO 4} & $\begin{array}{l}\text { Tx matrícula rede particular } \\
1996 \text { (anos iniciais) }\end{array}$ & 22 & $9,7 \%$ & $8,1 \%$ & $0,8 \%$ & $34,8 \%$ \\
\hline & $\begin{array}{l}\text { Tx matrícula rede particular } \\
2012 \text { (anos iniciais) }\end{array}$ & 32 & $12,6 \%$ & $7,9 \%$ & $0,4 \%$ & $34,9 \%$ \\
\hline & $\begin{array}{l}\text { Tx matrícula rede particular } \\
1996 \text { (anos finais) }\end{array}$ & 19 & $9,8 \%$ & $7,6 \%$ & $2,0 \%$ & $35,0 \%$ \\
\hline & $\begin{array}{l}\text { Tx matrícula rede particular } \\
2012 \text { (anos finais) }\end{array}$ & 31 & $12,9 \%$ & $7,6 \%$ & $1,6 \%$ & $36,4 \%$ \\
\hline
\end{tabular}

Nota-se o seguinte: a) no conjunto do estado, a média de percentual por município de matrículas na rede particular aumentou 2,8 pontos percentuais de 1996 para 2012, com alguns municípios chegando a ter $40 \%$ de seus alunos dos anos finais na rede privada em 2012; b) o GRUPO 1 (mais municipalizado) apresentou um crescimento da média municipal de matrículas privadas de 0,7 ponto percentual, contra 4,2 do GRUPO 2 (menos municipalizado) nos anos iniciais; c) no GRUPO1, ainda, o percentual máximo de alunos na rede privada por município caiu no período, de $24,9 \%$ para $21,0 \%$, indo contra uma tendência do estado; d) 
os GRUPOS 3 (Barretos) e 4 (médias altas) tiveram aumentos da média por municípios maiores que o do estado: 4,0 e 2,9, respectivamente.

\section{Evolução das médias em Língua Portuguesa das escolas}

O conjunto de gráficos a seguir apresenta a evolução das médias de Língua Portuguesa no $5^{\circ}$ ano, por escola, em cada um dos grupos particulares de análise. A evolução das médias do $9^{\circ}$ ano serão apresentadas apenas para o GRUPO 4 porque a evolução entre os anos de 2005 a 2011 é similar à dos anos iniciais nos demais. Chama atenção o fato de que apenas uma ínfima proporção de escolas alcança o patamar apontado como adequado nessa etapa, que é de 275 pontos, mesmo nesse GRUPO 4, no qual as médias de proficiência sempre foram altas, acima de 200 no $5^{\circ}$ ano.

Em relação à equidade, resumo uma percepção mais abrangente, com base em todos os dados analisados até aqui: 1) o fato de haver uma migração crescente para a rede privada já é um indicativo de aumento da desigualdade em si dentro do estado. Por alguma razão, o aumento da renda disponível da população aumenta sua propensão a pagar por um serviço que é oferecido gratuitamente pelo Estado; 2) os alunos que permanecem nas escolas públicas, muito provavelmente, são os mais pobres de suas cidades, assim, o fato das médias de proficiência estarem aumentado de forma consistente é uma boa notícia em termos de equidade; 3 ) nos municípios do GRUPO 1, com maior adesão à municipalização, o crescimento da proporção das matrículas na rede privada é ligeiramente menor que no GRUPO 2 e bem menor que no conjunto do Estado. O que explicaria isso?; 4) o crescimento das médias de proficiência das escolas é consistente em todos os GRUPOS, em praticamente todos os seus recortes de renda, mas nota-se que, em 2011, houve um aumento expressivo na dispersão das médias de proficiência por escola em todos os níveis de renda, um sinal preocupante de que algumas escolas estão "descolando" das demais, que também melhoram, mas em um ritmo bem mais lento; 5) além disso, no GRUPO 1, as escolas com pior desempenho não parecem estar melhorando nos municípios dos níveis 2 e 3 de renda, embora o restante do conjunto esteja. 
Gráfico 29 A a E: Evolução da média de proficiência por escola em Língua Portuguesa para cada GRUPO de interesse, por etapa de ensino e nível de renda Evolução das médias de LP - $5^{\circ}$ ano Grupo 1 - por renda domiciliar do município
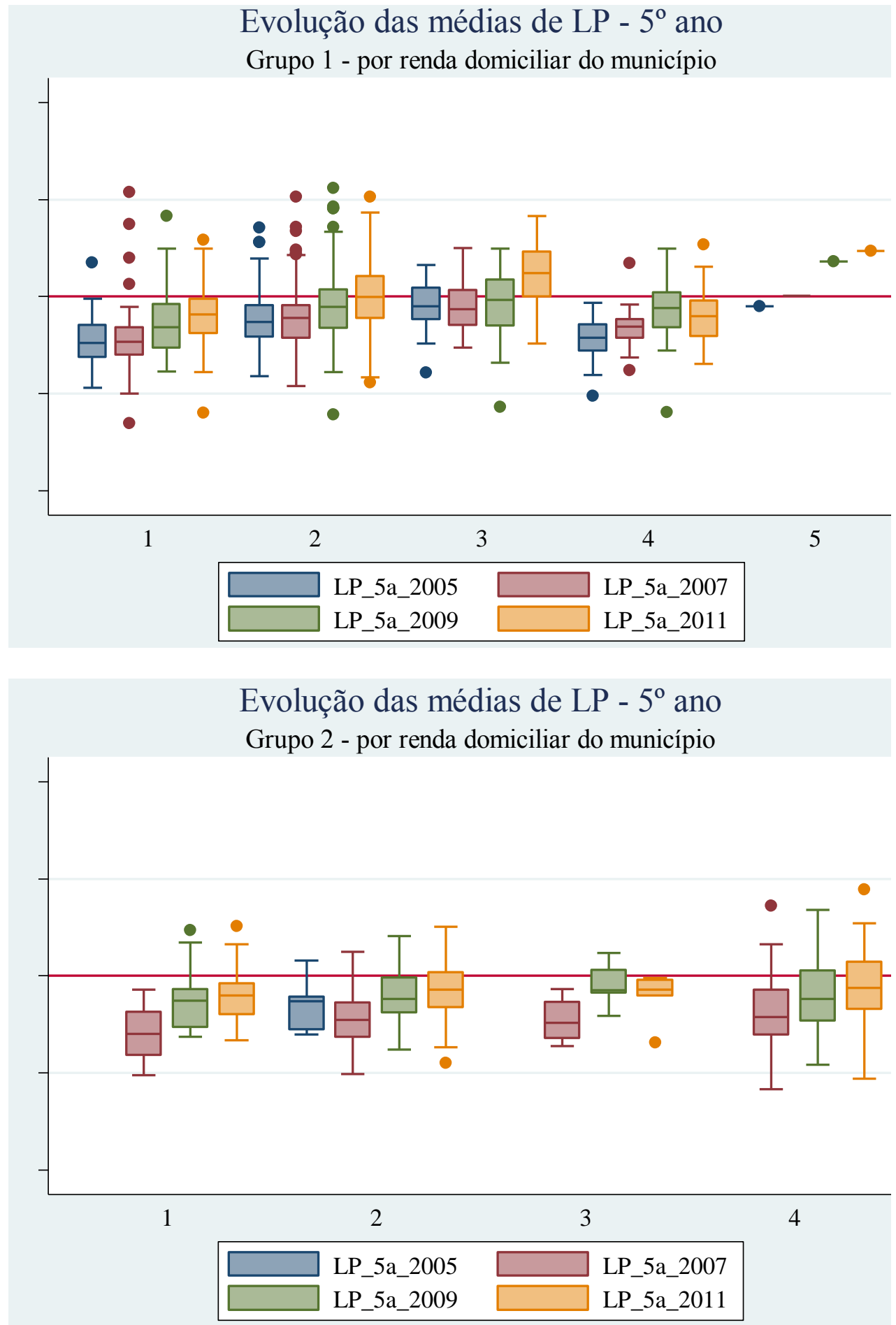
Evolução das médias de LP - $5^{\circ}$ ano

Grupo 3 - por renda domiciliar municipal

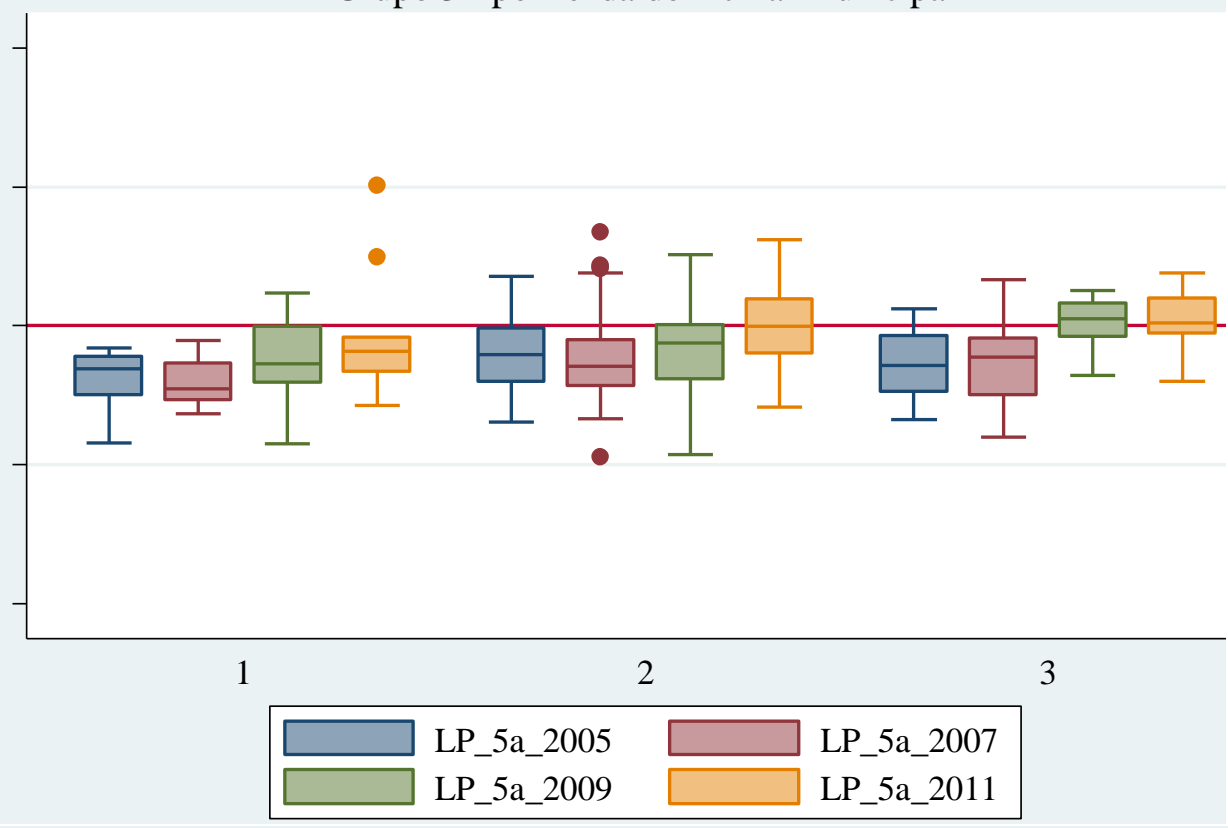

Evolução das médias em LP - $5^{\circ}$ ano Grupo 4

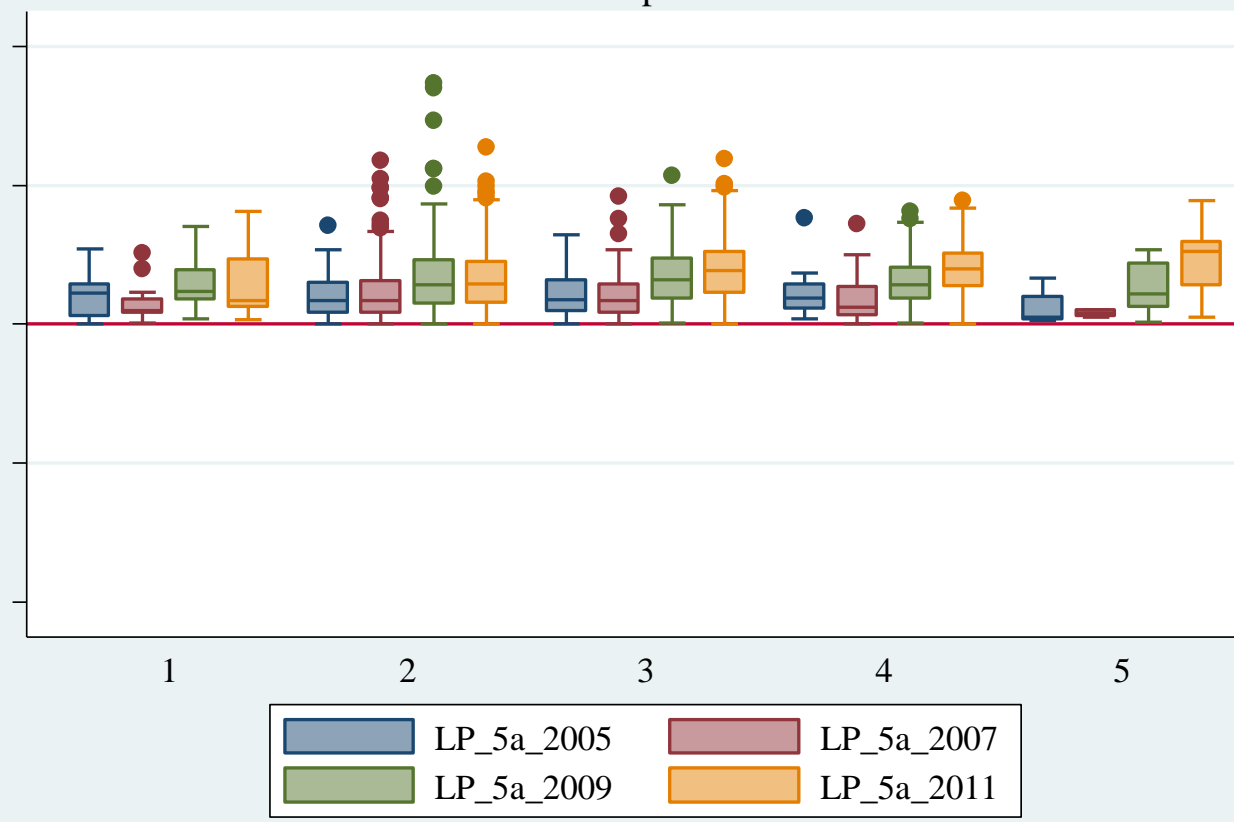


Evolução das médias de LP - $9^{\circ}$ ano

Grupo 4 - por renda domiciliar municipal

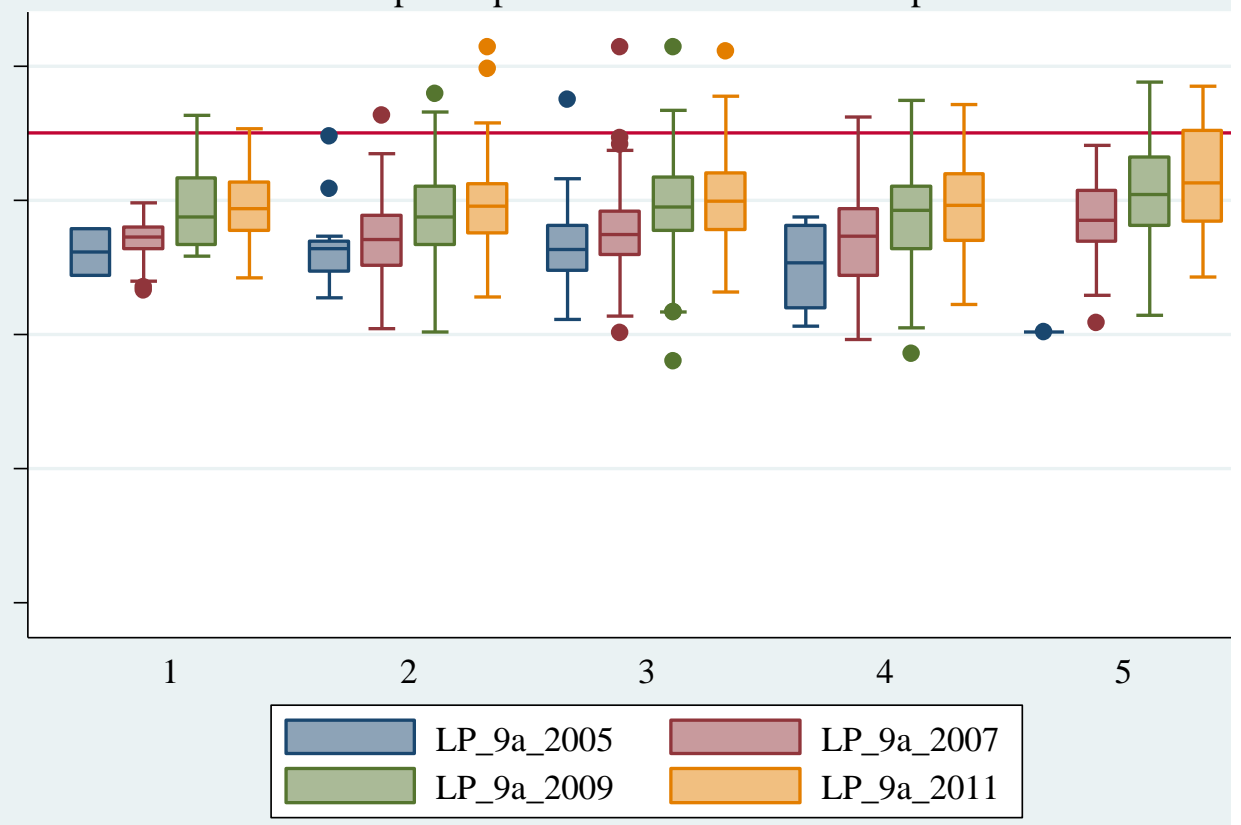




\section{Indicador complementar para comparar municípios}

Os levantamentos de dados, a investigação das possíveis relações entre eles e a busca pelas respostas às perguntas que pautaram este trabalho expuseram as limitações dos indicadores existentes na sua capacidade de diferenciar os municípios em relação ao esforço de cada localidade na oferta à população de serviços educacionais de qualidade.

O Ideb, indicador disseminado pelo Governo Federal para divulgar o andamento da educação para o público em geral, combina duas dimensões importantes, como já foi mostrado: a proficiência em Língua Portuguesa e em Matemática para os anos iniciais e finais de cada etapa da educação básica, com a progressão média dos alunos de um ano para o outro. O indicador foi de tal forma incorporado pela população (ou pelo menos pela imprensa) que rankings de toda sorte são feitos a cada edicação da Prova Brasil. Os rankings quase sempre empobrecem as discussões sobre a evolução da qualidade e equidade da educação por duas razões principais: a) colocam na mesma cesta municípios de perfil populacional completamente diferente e b) deixam de lado dimensões importantes do esforço deles em avançar os serviços educacionais que prestam à população.

Esta sessão procura, de forma muito simples e breve, apresentar uma sugestão de arranjo de dados existentes de forma a permitir uma análise comparativa mais abrangente entre municípios. Não é uma ideia original, pelo contrário, é mais uma tentativa de se pensar formas de apresentar informações mais completas para analisar o progresso educacional em nível municipal. Dois trabalhos recentes são exemplos dessa tendência: Soares \& Alves (2013) fazem uma composição de caraterísticas sociodemográficas dos indivíduos, escolas e municípios com a proficiência na provas (pgs. 505-506) para avaliar o efeito das escolas e dos municípios nos resultados dos alunos. Arretche, Fusaro \& Gomes (2012) 
construíram um indicador para diferenciar as condições de educação em diferentes contextos municipais, que combina uma gama de dimensões ${ }^{73}$ (pg. 34).

A proposta deste trabalho é um indicador que incorpore a taxa de municipalização como parâmetro inicial para diferenciar os municípios. Outras duas dimensões analisadas neste trabalho e incorporadas na sugestão do indicador, são: o tamanho do município e o nível de renda das famílias que nele habitam. Do ponto de vista da educação em si, o acesso e a permanência, dados, respectivamente, pelas dimensões de frequência escolar e da taxa de distorção idade-série, são combinadas com a proficiência em Língua Portuguesa e completam o quadro para cada etapa do ensino fundamental, conforme as tabelas a seguir.

Tabela 28: Cálculo do indicador proposto - anos inciais

\begin{tabular}{|lr|}
\hline Cálculo indicador - anos iniciais & Variação de valores \\
\hline Taxa de municipalização na etapa & $0-100$ \\
\hline Taxa de frequência na faixa etária correspondente & $0-100$ \\
\hline Taxa de distorção idade-série na etapa correspondente & $0-100$ \\
\hline Município no nível 1ou 2 de renda domiciliar & +100 pontos \\
\hline Município de população nível 5, 6 ou 7 & +100 pontos \\
\hline Sub-total características do município & $\mathbf{5 0 0}$ \\
\hline Média de proficiência adequada para a etapa & de 200 a 250 \\
\hline Valor máximo possível & $\mathbf{7 5 0}$ \\
\hline
\end{tabular}

\footnotetext{
73 Cobertura potencial até 6 anos

Taxa de reprovação até a $4^{\mathrm{a}}$ série do ensino fundamental

Taxa de reprovação da $5^{\mathrm{a}}$ à $8^{\mathrm{a}}$ série do ensino fundamental

Taxa de abandono até a $4^{\mathrm{a}}$ série do ensino fundamental

Taxa de abandono da $5^{\mathrm{a}}$ à $8^{\mathrm{a}}$ série do ensino fundamental Distorção idade-série até a $4^{\mathrm{a}}$ série do ensino fundamental

Proporção de escolas municipais com nota padronizada na Prova Brasil (4a série do ensino fundamental) inferior à média padronizada do Brasil Proporção de escolas municipais com nota padronizada na Prova Brasil ( $8^{\mathrm{a}}$ série do ensino fundamental) inferior à média padronizada do Brasil Nota Média Padronizada na $4^{\mathrm{a}}$ série do ensino fundamental na Prova Brasil Nota Média Padronizada na $8^{\mathrm{a}}$ série do ensino fundamental na Prova Brasil
} 
Tabela 29: Cálculo do indicador proposto - anos finais

\begin{tabular}{|l|r|}
\hline Cálculo indicador - anos finais & Variação de valores \\
\hline Taxa de municipalização na etapa & $0-100$ \\
\hline Taxa de frequência na faixa etária correspondente & $0-100$ \\
\hline Taxa de distorção idade-série na etapa correspondente & $0-100$ \\
\hline Município no nível 1ou 2 de renda domiciliar & +100 pontos \\
\hline Município de população nível 5, 6 ou 7 & +100 pontos \\
\hline Sub-total características do município & $\mathbf{5 0 0}$ \\
\hline Média de proficiência adequada para a etapa & de 275-325 \\
\hline Valor máximo possível & $\mathbf{8 2 5}$ \\
\hline
\end{tabular}

Como foi dito, uma das questões que se colocam na elaboração de indicadores de acompanhamento de políticas públicas é o uso que se faz deles. No caso dos rankings disseminados na imprensa não só pode-se estar sobre ou sub valorizando esforços locais, como reforçando mensagens incompletas para a população ou para os quadros técnicos de escolas e secretarias de educação. Vejamos a configuração de um ranking com os 20 melhores Idebs de 2011:

Tabela 30: Exemplo de ranking por Ideb - anos inciais

\begin{tabular}{|c|c|c|c|c|c|c|c|c|}
\hline Ranking & NOM_Munic & $\begin{array}{l}\text { Tx_Munic_ } \\
\text { AI_2010 }\end{array}$ & $\begin{array}{l}\text { TX_Freq_5 } \\
\text { a9anos } \\
\end{array}$ & $\begin{array}{l}\text { TDI_AI_20 } \\
11\end{array}$ & $\begin{array}{l}\text { COD_FX_ } \\
\text { RND }\end{array}$ & $\begin{array}{l}\text { COD_POP } \\
\text { _TOT }\end{array}$ & $\begin{array}{l}\text { LP_5a_201 } \\
1\end{array}$ & $\begin{array}{l}\text { IDEB_5a_2 } \\
011\end{array}$ \\
\hline 1 & Taiaçu & 1,00 & 0,99 & 7,20 & 1,00 & 2,00 & 250,39 & 8,20 \\
\hline 2 & Álvares Florence & 1,00 & 1,00 & 2,20 & 1,00 & 1,00 & 235,26 & 7,50 \\
\hline 3 & Caiuá & 1,00 & 0,95 & 4,40 & 1,00 & 2,00 & 238,44 & 7,50 \\
\hline 4 & Adolfo & 1,00 & 0,98 & 7,20 & 1,00 & 1,00 & 229,08 & 7,20 \\
\hline 5 & Cajuru & 1,00 & 0,98 & 6,60 & 2,00 & 4,00 & 238,10 & 7,20 \\
\hline 6 & Junqueirópolis & 1,00 & 0,94 & 3,50 & 2,00 & 3,00 & 229,06 & 7,20 \\
\hline 7 & Balbinos & 1,00 & 1,00 & 1,20 & 2,00 & 1,00 & 213,46 & 7,10 \\
\hline 8 & Santo Antonio do Jardim & 0,87 & 0,96 & 10,50 & 1,00 & 2,00 & 230,31 & 7,10 \\
\hline 9 & Duartina & 1,00 & 0,98 & 1,60 & 2,00 & 3,00 & 223,03 & 7,00 \\
\hline 10 & Holambra & 1,00 & 0,99 & 7,80 & 3,00 & 3,00 & 229,00 & 7,00 \\
\hline 11 & Itápolis & 0,29 & 0,99 & 0,50 & 2,00 & 4,00 & 236,74 & 7,00 \\
\hline 12 & Sebastianópolis do Sul & 1,00 & 1,00 & 2,10 & 2,00 & 1,00 & 237,37 & 7,00 \\
\hline 13 & Tanabi & 1,00 & 0,99 & 6,00 & 2,00 & 4,00 & 222,68 & 7,00 \\
\hline 14 & Bálsamo & 1,00 & 0,98 & 1,00 & 2,00 & 2,00 & 221,54 & 6,90 \\
\hline 15 & Echaporã & 1,00 & 0,98 & 5,30 & 2,00 & 2,00 & 219,64 & 6,90 \\
\hline 16 & Meridiano & 1,00 & 0,97 & 1,00 & 2,00 & 1,00 & 224,48 & 6,90 \\
\hline 17 & Nuporanga & 1,00 & 0,97 & 9,90 & 2,00 & 2,00 & 219,55 & 6,90 \\
\hline 18 & Paraíso & 1,00 & 0,98 & 3,90 & 2,00 & 2,00 & 229,14 & 6,90 \\
\hline 19 & Cerquilho & 1,00 & 1,00 & 2,90 & 3,00 & 4,00 & 225,64 & 6,80 \\
\hline 20 & Gabriel Monteiro & 1,00 & 1,00 & 3,40 & 2,00 & 1,00 & 213,23 & 6,80 \\
\hline
\end{tabular}

A classificação coloca no mesmo grupo 18 municípios com 100\% das matrículas municipalizadas e dois que não fizeram o mesmo esforço. Itápolis, por exemplo, só controla 29\% das matrículas, mas apresenta um Ideb de 7,00. Sto. Antônio do Jardim combina $87 \%$ de municipalização com mais de $10 \%$ de taxa de distorção idade-série nos anos iniciais. Dos 20 municípios desse ranking, dois têm nível de 
renda familiar média (enquanto os demais têm muito baixa ou muito baixa) e três têm população acima de 20 mil habitantes, enquanto os demais têm que atender às demandas sociais de até 20 mil pessoas, ou até de 5 mil, no caso dos municípios de nível 1.

Ao se fazer uma nova classificação utilizando o indicador sugerido aqui para os anos iniciais, os Idebs são mais baixos que o da tabela anterior, mas os municípios são mais homogêneos em termos dos indicadores apresentados.

Tabela 31: Exemplo de ranking pelo indicador proposto - anos iniciais

\begin{tabular}{|c|c|c|c|c|c|c|c|c|c|}
\hline Ranking & NOM_Munic & $\begin{array}{l}\text { INDIC_- } \\
\text { Novo_AI }\end{array}$ & $\begin{array}{l}\text { Tx_Muni } \\
\text { c_AI_201 }\end{array}$ & $\begin{array}{c}\text { TX_Freq } \\
\text { 5a9ano }\end{array}$ & $\begin{array}{l}\text { TDI_AI_ } \\
2011\end{array}$ & $\begin{array}{l}\text { COD_FX } \\
\text { RND }\end{array}$ & $\begin{array}{l}\text { COD_P } \\
\text { OP_TOT }\end{array}$ & $\begin{array}{l}\text { LP_5a_2 } \\
011\end{array}$ & $\begin{array}{l}\text { IDEB_5a } \\
2011\end{array}$ \\
\hline 1 & Lençóis Paulista & 615,46 & 1,00 & 0,99 & 6,10 & 2,00 & 5,00 & 222,84 & 6,50 \\
\hline 2 & Birigui & 609,87 & 0,97 & 0,99 & 2,70 & 2,00 & 6,00 & 216,48 & 6,30 \\
\hline 3 & Mogi Guaçu & 609,14 & 1,00 & 0,98 & 8,00 & 2,00 & 6,00 & 219,09 & 6,20 \\
\hline 4 & Olímpia & 604,55 & 1,00 & 0,97 & 4,10 & 2,00 & 5,00 & 211,38 & 6,20 \\
\hline 5 & Barueri & 602,14 & 1,00 & 0,98 & 9,90 & 2,00 & 6,00 & 214,02 & 5,90 \\
\hline 6 & Mirassol & 600,08 & 1,00 & 0,93 & 6,10 & 2,00 & 5,00 & 212,93 & 6,10 \\
\hline 7 & Votorantim & 597,20 & 1,00 & 0,98 & 3,00 & 2,00 & 6,00 & 202,20 & 5,90 \\
\hline 8 & Fernandópolis & 594,59 & $\mathbf{0 , 8 6}$ & 0,99 & 2,20 & 2,00 & 5,00 & 211,85 & 6,30 \\
\hline 9 & Campo Limpo Paulista & 593,68 & 1,00 & 0,98 & 7,50 & 2,00 & 5,00 & 203,59 & 5,50 \\
\hline 10 & Taquaritinga & 593,49 & 1,00 & 0,98 & 4,00 & 2,00 & 5,00 & 199,60 & 5,80 \\
\hline 11 & Leme & 593,27 & 1,00 & 0,97 & 5,70 & 2,00 & 5,00 & 202,19 & 5,80 \\
\hline 12 & Santa Isabel & 592,52 & 1,00 & 0,97 & 7,90 & 2,00 & 5,00 & 203,57 & 5,50 \\
\hline 13 & Itanhaém & 591,55 & 1,00 & 0,97 & 5,50 & 2,00 & 5,00 & 200,65 & 5,40 \\
\hline 14 & Tatuí & 591,47 & 1,00 & 0,97 & 6,30 & 2,00 & 6,00 & 200,65 & 5,50 \\
\hline 15 & Andradina & 590,34 & 1,00 & 0,98 & 2,20 & 2,00 & 5,00 & 194,83 & 5,60 \\
\hline 16 & Bebedouro & 588,76 & 1,00 & 0,99 & 5,00 & 2,00 & 5,00 & 194,63 & 5,60 \\
\hline 17 & Hortolândia & 586,61 & 0,93 & 0,98 & 2,80 & 2,00 & 6,00 & 198,75 & 5,60 \\
\hline 18 & Santa Bárbara d'Oeste & 586,21 & 0,74 & 0,99 & 3,20 & 2,00 & 6,00 & 216,37 & 6,30 \\
\hline 19 & Mairiporã & 585,68 & 1,00 & 0,95 & 3,50 & 2,00 & 5,00 & 194,51 & 5,50 \\
\hline 20 & Várzea Paulista & 583,61 & 0,97 & 0,96 & 3,00 & 2,00 & 6,00 & 193,12 & 5,30 \\
\hline
\end{tabular}

Se estamos em um processo de correr contra o tempo e compensar atrasos sociais, ao mesmo tempo que já conseguimos produzir dados educacionais com qualidade, quantidade, regularidade e credibilidade, podemos aprofundar as análises para poder contribuir mais para o desenho, monitoramento e avaliação de políticas educacionais. Os novos perfis de trabalhos acadêmicos que detalham políticas como a descentralização ou que apresentam formas adicionais de análise de dados podem ser um indicativo de que o país já está nesse caminho. 


\section{Perspectivas futuras e conclusões}

O contato profissional com a realidade educacional de inúmeros municípios do Estado de São Paulo fez brotar em mim as perguntas e a motivação para fazer este trabalho. A realidade é sempre mais complexa que os relatos que se pode fazer dela, portanto, depois de analisar os dados das bases estatísticas oficiais e os conceitos e informações da bibliografia selecionada, concluí que a transferência de matrículas do Estado de São Paulo para seus municípios é uma política ao mesmo tempo consolidada e estudada, mas ainda muito pouco compreendida, principalmente nas formas de implementar.

A implementação é chave para qualquer empreitada: depois de receber as matrículas, as Prefeituras devem se empenhar para desenhar e por de pé estruturas educacionais competentes. Mas a estrutura do estado era originalmente competente a ponto de poder estabelecer padrões e dar o exemplo, ou localmente teria que se reinventar a roda centenas de vezes? O levantamento feito aqui não permite responder a essa pergunta, apenas perceber que as formas de implementar podem constituir hipóteses de explicação para as diferenças de resultado que encontramos aqui.

Atualmente o contexto econômico, financeiro e político é muito diferente do que era em 1995. Mesmo que em termos de partido político a gestão seja a mesma desde o início do processo de transferência de matrículas no estado. Interesses antagônicos à política permanecem, mas talvez tenham mudado de lugar. É, portanto, difícil prever que perspectivas futuras a política de transferência de matrículas terá no Estado de São Paulo, ou pelo menos projetar o que foi concluído aqui no futuro, tanto pela insuficiência do que foi analisado, quanto pela mudança de contexto.

Um exemplo do novo ambiente decisório é a exposição da opinião oficial da Secretaria de Educação do estado, responsável pela política, relatada a seguir. 
Em maço de 2011, o Secretário de Estado-Adjunto da Educação, João Cardoso Palma Filho foi interpelado, em um evento público, pela Secretária de Educação de Monte Azul Paulista, Regina Helena Del'Arco, sobre a dificuldade de relacionamento dos municípios com a Secretaria Estadual de Educação, devido aos obstáculos que as Diretorias Regionais representarem nesse relacionamento (no caso de seu município, relevante, porque a segunda etapa do enisno fundamental é compartilhada com o estado). Sua resposta:

O que eu tenho notado por parte dos professores da nossa rede [estadual] é um receio de que mais escolas sejam municipalizadas e que eles fiquem em uma situação profissional extremamente difícil. Só quero concluir e mostrar qual é a posição hoje. Na realidade, à medida que o Secretário [Hermann Voowald] esclarecer à rede, e já está fazendo, na direção de que nós não vamos municipalizar mais nada. Acabou, esta é a questão. Nós não vamos, a não ser em casos muito excepcionais, manter, no ritmo que vinha vindo, o programa de municipalização. Tem, inclusive, uma questão financeira nisso: nos estamos transferindo para os municípios transferimos, em 2010 - R\$ 3 bilhões, entretanto, não transferimos todos os encargos. Ficamos [com eles]. Nós temos situação em alguns municípios que não querem receber os nossos professores, então, eu fico com eles adidos, pagando. A folha de pagamento é minha. Por outro lado, no regime de compensação, nós temos a receber dos municípios quase $\mathrm{R} \$ 11$ bi [lhões] e não [es] tamos recebendo. Então, como dizem popularmente: "devagar com o andor que o santo é de barro". Quer dizer, nós vamos, já existe uma decisão do Secretário de que, principalmente, do $6^{\circ}$ ao $9^{\circ}$ ano não vamos fazer transferência para os municípios, a não ser, como eu disse, em casos excepcionais. À medida que a nossa rede passa a ter conhecimento disso, eu acredito que o principal obstáculo que existe para uma boa convivência, no âmbito do município, deixa de existir. Porque a resistência é esta: a Secretária municipal vem aí e então vai municipalizar minha escola, e eu, como fico? Eu como costumo ver os dois lados da história, eu acho que o receio que o professor tem, na medida que ele não teve nenhum esclarecimento a respeito, é válido. É pertinente, é procedente. Agora, casos como este que a colega menciona, como o do Projeto Guri, acho que resolve simplesmente entrando em contato com o gabinete do Secretário, já que em que o Dirigente é resistente, o Secretario determina que possa utilizar e acabou. (O vídeo original pode ser acessado em: http://www.youtube.com/watch?v=0BR3qaWPf5Y, último acesso em 22/10/2013)

Assim, em termos de perspectivas futuras, a conclusão é: uma ingógnita. O futuro da política parece estar para ser decidido mais com base em restrições 
políticas e financeiras que em avaliações de seu impacto, ainda escassas e inconclusivas em nível nacional, principalmente.

Quanto às análises feitas nesta pesquisa, com base nos dados de séries temporais de matrícula, por tipo de dependência administrativa e das avaliações externas nacionais, confrontados com alguns aspectos de perfil populacional municipal a partir do Censo IBGE de 2010 e de indicadores educacionais disponibilizados pelo Inep, algumas constatações foram possíveis.

1) O processo de transferência de matrículas do estado para os municípios em São Paulo teve realmente início na gestão Covas-Neubauer, que combinou uma estrutura legal de parceria estado-municípios, com a sistemática de equalização de gastos por matrícula induzida pelo Fundef/b, diferentemente de outras unidades da federação que fizeram outros percursos. A forma de municipalizar em São Paulo induziu muitas localidades construir sistemas educacionais que estão colhendo resultados mais rapidamente que a rede estadual original, isso só foi possível ser identificado de forma sistemática quando se separou os que municipalizaram as duas etapas do ensino fundamental dos municípios que absorveram uma proporção pequena de matrículas.

Não foi possível perceber, entretanto, porque essas cidades empreenderam esforços distintos e se comprometeram com a educação fundamental e as demais, não. As pistas que surgiram da revisão bibliográfica com os relatos de campo apontam mais para as razões para não municipalizar (alinhamento político com o sindicato docente ou constrangimento pelo movimento docente), mas não trouxe informações sobre porque um município iria além de municipalizar os anos iniciais do ensino fundamental. Surge a necessidade de dar continuidade a esta pesquisa com um levantamento qualitativo para identificar essas razões.

2) As caraterísticas municipais identificadas nesta pesquisa serviram para mostrar que há diferenças de ritmo de municipalização e que estas podem ser sistemáticas, relacionadas a algumas variáveis de cunho local. Este estudo mostrou que tamanho da população e a renda das famílias tiveram relação sistemática com o ritmo da municipalização no Estado de São Paulo, sendo que a primeira influenciou o processo negativamente e a segunda, positivamente. A produção de renda do município e a região administrativa onde ele está localizado, 
não apresentaram uma relação sistemática com o processo, embora tenha sido possível destacar uma delas pelo critério de percentual de municipalização.

A questão das diferenças do ritmo de aumento de matrículas na rede particular entre os quatro GRUPOS de interesse chamou particularmente atenção e foi inesperada para o escopo do trabalho. Esse aspecto também deve ser melhor investigado porque parece de alguma forma estar relacionado com a política pública em questão.

Também permanece a dúvida de porque porque a Região Administrativa de Barretos teve um processo mais homogêneo (assim como duas RAs contíguas, Ribeirão Preto e Franca) que as demais. Embora tenha pesquisado um pouco sobre a existência de consórcios intermunicipais na região, que explicassem esforços conjuntos e institucionalizados, não tive sucesso em encontrar nenhuma informação nesse sentido.

Sobre a pergunta de pesquisa que se relaciona à esfera administrativa que vem conseguindo prestar melhor atendimento educacional à população, a resposta é: depende. Se a rede municipal se comprometer com a educação do aluno e, neste estudo, o comprometimento foi quantificado pelo nível de municipalização em ambas as etapas do ensino fundamental, sim. Se não houver compromisso (que provavelmente pode ser medido de formas alternativas à que se fez aqui), não foi possível avaliar. A existência de renda mais elevada das famílias (associada a níveis mais altos de educação) pode acarretar tanto a fuga do sistema público de ensino, quanto a pressão por melhores serviços públicos. A compreensão da diferença do que causa cada tipo de caso não foi estudada neste trabalho.

Depois de muitas análise e poucos achados, ficaram perguntas novas, mas algumas conclusões sobre a política de descentralização parecem ter emergido deste esforço.

A primeira é de que a transferência de matrículas do ensino fundamental do nível estadual para o municipal pode (e deve) ser melhor qualificada para ser mais amplamente compreendida como política pública. Neste estudo, por exemplo, percebeu-se que os municípios do Estado de São Paulo que se comprometeram com o ensino fundamental como um todo, colocando sob sua responsabilidade a 
totalidade das matrículas tanto em seus anos iniciais, quanto nos finais (além das que as antecedem, creche e pré-escola) demonstraram boa evolução de resultados educacionais, medidos pelas informações disponíveis. Essa evolução positiva se relacionou com a manutenção na rede municipal de um público que poderia ter migrado para as redes privadas instaladas na maior parte dos municípios.

Seria interessante verificar se o que foi encontrado no Estado de São Paulo se repete em outras unidades da federação que por ventura tenham utilizado mecanismos similares de transferência de matrícula que, neste caso, se deu acompanhada de recursos humanos e materiais e de providências de colaboração estado-município. O papel de consórcios e de diferentes tipos de agremiação intermunicipal no ritmo e resultados das redes escolares municipais também despertou meu interesse, mas ficou ao largo deste estudo.

A segunda é que a comparação entre estados e municípios deve levar em conta o conjunto do esforço local para o atendimento das necessidades educacionais de cada população e que esse conjunto contempla acesso, permanência e conclusão de cada etapa obrigatória, além do desempenho de todos os estudantes em provas padronizadas em larga escala. $\mathrm{O}$ foco em um indicador como o Ideb, que não contempla o esforço integral de cada ente federado pode vir acompanhado de distorções no acompanhamento da evolução da educação brasileira.

Termino o trabalho citando mais uma vez Azanha (1991) quanto ao cerne do debate:

Em face dos propósitos visados, vamos deter a nossa atenção apenas na irresponsabilidade cívica com relação aos destinos da escola pública. Porque é com relação a esse ponto que pretendemos tentar responder à questão sobre a possível contribuição que a municipalização do ensino pode dar para reverter a atual situação da escola pública.

Essa contribuição será uma decorrência do modo de conceber a municipalização. Como dissemos anteriormente, o fundamental é municipalizar a preocupação com o problema educacional e isso não será feito por nenhuma providência legal. A municipalização precisa consistir num movimento de convocação e mobilização de todos os setores da sociedade local no sentido de salvação da escola pública. E isso, evidentemente, só tangencialmente está ligado à administração do ensino e à construção ou reforma de prédios escolares. Dentre os fatores desencadeantes da crise da escola pública, há componentes psicossociais muito fortes e que poderiam ser 
designados pela expressãofalta de compromisso com a escola pública. Falta de compromisso profissional e político do magistério e falta de compromisso cívico de toda a comunidade. E uma questão de mentalidade. Não há mais tempo a perder. Em matéria de educação pública, atingimos um ponto-limite. Além dele, é possível a tragédia e a convulsão social. Ou salvamos a escola pública ou fixaremos um destino de miséria física e social para milhões de crianças. (AZANHA, 1991, pg. 66) [grifo meu] 


\section{Referências Bibliográficas}

\section{Legislação}

BRASIL. Constituição (1967). Constituição da República Federativa do Brasil de 1967: promulgada em 24 de janeiro de 1967. Disponível em: http://www.planalto.gov.br/ccivil_03/Constituicao/Constitui\%C3\%A7ao67. htm. Acesso: 4 dez. 2012.

Constituição (1988). Constituição da República Federativa do Brasil: promulgada em 5 de outubro de 1988. Disponível em: http://www.planalto.gov.br/ccivil_03/constituicao/constituicao.htm. Acesso: 4 dez. 2012.

Lei no. 9.394, de 20 de dezembro de 1996. Estabelece as Diretrizes e Bases da Educação Nacional. Diário Oficial da União, Poder Executivo, Brasília, DF, 23 dez. 1996, p. 27833-27841.

Lei 11.274, de 6 de fevereiro de 2006. Altera a redação dos arts. 29, 30, 32 e 87 da Lei no 9.394, de 20 de dezembro de 1996, que estabelece as diretrizes e bases da educação nacional, dispondo sobre a duração de 9 (nove) anos para o ensino fundamental, com matrícula obrigatória a partir dos 6 (seis) anos de idade. Presidência da República, Congresso Nacional. Diário Oficial da União, Brasília, 7 de fevereiro de 2006, p. 1.

. Comissão de Constituição e Justiça e de Cidadania: redação final. Projeto de Lei No 8.035-B DE 2010 - Plano Nacional de Educação

Lei No 10.172, de 9 de janeiro de 2001. (PNE 2001)

Emenda Constitucional $N^{\circ} 59$, de 11 de novembro de 2009. Acrescenta $\S 3^{\circ}$ ao art. 76 do Ato das Disposições Constitucionais Transitórias para reduzir, anualmente, a partir do exercício de 2009, o percentual da Desvinculação das Receitas da União incidente sobre os recursos destinados à manutenção e desenvolvimento do ensino de que trata o art. 212 da Constituição Federal, dá nova redação aos incisos I e VII do art. 208, de forma a prever a obrigatoriedade do ensino de quatro a dezessete anos e ampliar a abrangência dos programas suplementares para todas as etapas da educação básica, e dá nova redação ao $\S 4^{\circ}$ do art. 211 e ao $\S 3^{\circ}$ do art. 212 e ao caput do art. 214, com a inserção neste dispositivo de inciso VI

Câmara de Educação Básica do Conselho Nacional de Educação. Parecer N. o: CEB 38/2002. Consulta sobre os artigos 23 e 24 da Lei 9394/96, Aprovado em: 04.11 .2002 
MINISTÉRIO DA EDUCAÇÃO. Gabinete do Ministro. Portaria No 931, de 21 de março de 2005. Institui o Sistema de Avaliação da Educação Básica - SAEB, que será composto por dois processos de avaliação: a Avaliação Nacional da Educação Básica ANEB, e a Avaliação Nacional do Rendimento Escolar - ANRESC, e estabelece suas diretrizes

Portaria no 149, de 16 de junho de 2011. Estabele a sistemática para a realização da Avaliação Nacional do Rendimento Escolar ANRESC (Prova Brasil) e da Avaliação Nacional da Educação Básica - ANEB, no ano de 2011.

Educacionais Anísio Teixeira. Nota Informativa do Ideb 2011 Nota Informativa do Ideb 2011.

http://download.inep.gov.br/educacao_basica/portal_ideb/o_que_e_o_ideb/nota_infor mativa_ideb_2011.pdf. Acesso em 19/11/2013.

\section{Citações}

ABREU, M. Levantamento de Dados, Textos, Artigos, etc. Sobre Municipalização do Ensino, com Ênfase no Estado do Maranhão. Brasília: Câmara dos Deputados, Consultoria Legislativa - Estudo - Julho 2003.

ADRIÃO, T. Oferta do Ensino Fundamental em São Paulo: um novo modelo. Campinas: Educação e Sociedade, vol. 29, n. 102, p. 79-98, jan./abr. 2008

Sistemas apostilados de ensino e municípios paulistas: o avanço do setor privado sobre a política educacional local. São Paulo: Relatório Técnico, Fapesp Processo no 2010/00490-0. Campinas: Faculdade de Educação - Unicamp, 2011

ADRIÃO, T. et al . Uma modalidade peculiar de privatização da educação pública: a aquisição de "sistemas de ensino" por municípios paulistas. Campinas: Educação $e$ Sociedade, vol. 30, n. 108, p. 799-818, outubro 2009

ALMEIDA, A.C. A cabeça do brasileiro. Rio de Janeiro: Record, 2007

ALMEIDA, M.H.T. \& CARNEIRO, N.P. The new local agenda: elite support for decentralization of social services in Brazil. Paper prepared for the Panel The Politics of Local-Global Relations, IPSA Congress, Quebec, August 2000. Disponível em: http://www.fflch.usp.br/dcp/assets/docs/MariaHerminia/agenda.pdf

ALMEIDA, M.H. T. Federalismo, democracia e governo no Brasil: idéias, hipóteses e evidências. São Paulo: Revista Brasileira de Informação Bibliográfica em Ciências Sociais 51 (2001): 13-34.

ALVES, F.C.M. Qualidade na Educação Fundamental Pública nas Capitais Brasileiras: tendências, contextos e desafios. Belo Horizonte: 2009, Argvmentvm. 
ANDREWS, C.W., De VRIES, M. Pobreza e municipalização da educação: análise dos resultados do IDEB (2005-2009). São Paulo: Cadernos de Pesquisa, vol. 42, iss. 147, pp. 826-847 dez. 2012

ARAÚJO, G.C. Município, Federação e educação: história das instituições e das ideias políticas no Brasil. Tese de Doutorado. Universidade de São Paulo, 28/6/2005, 332 pgs.

ARELARO, L.R.G. Formulação e implementação das políticas públicas em educação e as parcerias público-privadas: impasse democrático ou mistificação política? Campinas: Educação e Sociedade, v. 28, n. 100, out. 2007

ARRETCHE, M. Estado Federativo e Políticas Sociais: determinantes da descentralização. Rio de Janeiro: Revan; São Paulo: FAPESP, 2000, $3^{\text {a }}$ edição, agosto de 2011.

Federalismo e políticas sociais no Brasil: problemas de coordenação e autonomia. São Paulo em Perspectiva, Jun 2004, vol.18, no.2, p.17-26. ISSN 01028839

ARRETCHE, M., FUSARO, E., GOMES, S. Democracia, Políticas Sociais e Pobreza no Brasil. Trabalho apresentado no 8o. Encontro da Associação Brasileira de Ciência Política, Gramado, RS - 1o.-4 de agosto de 2012

AZANHA, J.M.P. Uma idéia sobre a municipalização do ensino. Estudos Avançados [online]. 1991, vol.5, n.12, pp. 61-68. ISSN 0103-4014. http://dx.doi.org/10.1590/S0103-40141991000200005. Acesso em 9/1/2014

AZEVEDO et al. Manifestos dos Pioneiros da Educação Nova (1932) e dos Educadores (1959). Recife: Fundação Joaquim Nabuco, Editora Massangana, 2010. 122 p. - (Coleção Educadores). ISBN 978-85-7019-516-6

BANCO MUNDIAL, Envelhecendo em um Brasil mais Velho: implicações do envelhecimento populacional sobre crescimento econômico, redução da pobreza, finanças públicas e prestação de serviços (Sumário). Brasília: Banco Mundial Departamento do Brasil, 2011.

BOMFIM, M.I. Trabalho docente na educação básica: a atual agenda do Banco Mundial. Biblioteca Técnica do Senac: ??

BROOKE, N. \& CUNHA, M.A.A., A avaliação externa como instrumento da gestão educacional nos estados. São Paulo: Fundação Vitor Civita, Estudos e Pesquisas Educacionais - volume 2, 2011

CANO, S.G.G., O financiamento da educação pública e seu impacto na qualidade dos serviços ofertados no ensino fundamental municipal dos municípios do Estado de São Paulo entre 1999 e 2006. Dissertação de Mestrado. Campinas: Instituto de Economia, UNICAMP, 5/4/2010, 141 pgs. 
CENEVIVA, R. O Nível de governo importa para a qualidade da política pública? Tese de Doutirado. São Paulo: Departamento de Ciência Política da Faculdade de Filosofia, Letras e Ciências Políticas da USP, 2011

Compendio de Demandas y Propuestas Estudiantiles Coordinadora Nacional de Estudiantes Secundarios CONES. http://www.elciudadano.cl/wpcontent/uploads/2012/08/propuesta-cones.pdf. Acesso em 20/01/2014.

CARNOY, M. Mundialização e reforma da educação: o que os planejadores devem saber, tradução de Guilherme João de Freitas Teixeira. Brasília: UNESCO, 2002

COSTA RIBEIRO, S. A Pedagogia da Repetência. São Paulo: Estudos Avançados, v. 5, n. 12, maio/ago.

D'ATRI, F. Municipalização do ensino fundamental da rede pública: os impactos sobre o desempenho escolar. Dissertação de Mestrado. São Paulo: Escola de Economia de São Paulo da Fundação Getúlio Vargas, 2007, 52 pgs.

ESPÓSITO, I.C. A municipalização de ensino fundamental e qualidade do ensino: estudo de caso do município de Martinópolis. Dissertação de mestrado. Presidente Prudente: UNOESTE, 29/4/2010, 170 pgs.

FIGUEIREDO, D. M.L.. Gestão Municipal, Qualidade de Ensino e a Avaliação do Rendimento Escolar: Um Estudo do Município de Cosmorama. Tese de doutorado. Araraquara: Faculdade de Educação, Universidade Estadual Paulista "Julio de Mesquita Filho" Campus de Araraquara, 14/2/2008, 367 pgs.

FREYRE, G. Casa Grande e Senzala. Rio de Janeiro: Record, 2000

GAJARDO, M. Reformas educativas na América Latina. Balanço de uma década.

Santiago: PREAL Programa de Promoção da Reforma Educativa na América Latina e Caribe, Preal Documentos nº15, Setembro de 1999

GATTI, B.A. , BARRETTO E.S. (Coord.) Professores do Brasil: impasses e desafios. Brasília: UNESCO, 2009. 294 p. ISBN: 978-85-7652-108-2

GHANEN, E. et al. A municipalização do ensino em São Paulo. São Paulo: Ação Educativa Assessoria Pesquisa e Informação; Campanha Nacional Pelo Direito à Educação; Apeoesp. Março, 2001. http://www.bdae.org.br/dspace/handle/123456789/2282

GOMES, S. C. Fatores explicativos das diferentes estratégias de municipalização do ensino fundamental nos governos subnacionais do Brasil (1997-2000). Tese de doutorado. Departamento de Ciência Política da Faculdade de Filosofia, Letras e Ciências Humanas da Universidade de São Paulo, 2008, 265 pgs.

HARGREAVES, A. \& FULLAN, M. Change Wars. Bloomington, IN: Solution Tree, 2009. ISBN: 978-1-934009-31-4 
HOLANDA, S.B. Raízes do Brasil. São Paulo: Companhia das Letras, 2008

KRAWCZYK, N.R. A sustentabilidade da reforma educacional em questão: a posição dos organismos internacionais. Rio de Janeiro: Revista Brasileira de Educação, no.19, p.43-62, Abril 2002

KRAWCZYK, N. R. Políticas de regulação e mercantilização da educação: socialização para uma nova cidadania?. Campinas: Educação e Sociedade, vol.26 no.92, Outubro 2005

LEME, M.C.L. et al. The Impact of Structured Teaching Methods on The Quality of Education in Brazil. REAP - Rede de Economia Aplicada. Working Paper 025. Março, 2012

LEME, M.C., PAredes, R. \& SOUZA, A.P. A Municipalização do Ensino Fundamental e seu Impacto Sobre a Proficiência No Brasil. ??, 2009

LOURENÇO F ${ }^{\circ}$, M. B. A pedagogia de Rui Barbosa. $4^{a}$ edição. Brasília: INEP/MEC, 2001

MACEDO, M.Q. A instituição da supervisão de ensino e a municipalização em Valinhos: tensões, conflitos e incertezas. Dissertação de mestrado. São Carlos: Universidade Federal de São Carlos - Centro de Educação e Ciências Humanas Programa de Pós-graduação em Educação, 2008

MARTINS, P.S. Controle Social na Fiscalização do Fundeb. Brasília: Câmara Legislativa, Estudos, 2009

MELLO, G.N., NOGUEIRA, M.J.Cidadania e competitividade: desafios educacionais do terceiro milênio. 10ª edição. Campinas: Cortez; 1995. 204 p.

MILITÃO, S.C. N. O processo de municipalização do ensino no Estado de São Paulo: uma análise do seu desenvolvimento na Região de Governo de Marília. Tese de Doutorado. Marília: Faculdade de Filosofia e Ciências, Universidade Estadual Paulista, 2007

MORAES, G. Z. O Processo de Municipalização do Ensino em Itirapina: a experiência de uma década. Dissertação de mestrado. São Carlos: Universidade Federal de São Carlos, 2009.

MOURSHED, M. How the world's best performing school systems come out on top. McKinsey, 2007

MOURSHED, M., CHINEZI \& BARBER. How the world's most improved school systems keep getting better. McKinsey, 2010

NEUBAUER, R. Estado e municípios - parceiros na educação. São Paulo: São Paulo em Perspectiva, v.10/ nº.3/ Jul-Set 1996

OECD, Education at a Glance 1998: OECD Indicators. Paris: OECD Publishing, 1998. http://www.oecd-ilibrary.org/content/book/eag-1998-en (PDF) 
Education at a Glance 2013: OECD Indicators. Paris: OECD Publishing, 2013. http://dx.doi.org/10.1787/eag-2013-en. ISBN 978-92-64-20105-7 (PDF)

, Knowledge and Skills for Life: first results from the OECD Programme for International Students Assessment (PISA) 2000. Paris, OECD Publishing, 2001 Learning for Tomorrow's World: First Results from PISA 2003. Paris, OECD Publishing, 2004

PISA 2006 Science Competencies for Tomorrow's World. Paris, OECD Publishing, 2007

PISA 2009 Results: What Students Know and Can Do: Student Performance in Reading, Mathematics and Science. Paris, OECD Publishing, 2010. http://dx.doi.org/10.1787/9789264091450-en

PISA 2012 Results: What Students Know and Can Do Student Performance in Mathematics, Reading and Science. Paris, OECD Publishing, 2013. http://dx.doi.org/10.1787/9789264201118-en

PATTO, M. H. S. A produção do fracasso escolar: histórias de submissão e rebeldia. São Paulo: T. A. Queiroz, 1991. 385 p.

PLANK, D.N. The Means of Our Salvation: public education in Brazil, 1930-1995. Colorado-EUA: Westview Press; Reino Unido: Westview Press, 1996.

PORTELA \& ARAUJO. Qualidade do ensino: uma nova dimensão da luta pelo direito à educação. Rio de Janeiro: Revista Brasileira de Educação. n 28 , Jan /Fev /Mar /Abr 2005

PRUD'HOMME, R. The dangers of decentralization. Washington: The World Bank Research Observer, vol. 10, no. 2 (august 1995). pp. 201-220

PUPO, C.C., Financiamento da educação e formação continuada de professores: o Fundef no município de Campinas. Dissertação de Mestrado. Campinas, Unicamp, 2012

RAMOS, M.D. Formação continuada de professores: novos arranjos institucionais após a decentralização do ensino fundamental. Dissertação de mestrado. Campinas: Unicamp, 2013.

REIS, R.R. O movimento docente e o debate sobre financiamento educacional: O caso da APEOESP (1995-2002). Dissertação de Mestrado. São Paulo, Pontifícia Universidade Católica de São Paulo. 2006

RIBEIRO, C.A.C.. Desigualdade de Oportunidades e Resultados Educacionais no Brasil. Rio de Janeiro: DADOS - Revista de Ciências Sociais, vol. 54, no 1, pp. 41 a 87,2011 
ROQUE, L. A Implementação da Municipalização do Ensino em Quatro Municípios da Região de São João da Boa Vista, SP - (1997-2003). Dissertação de mestrado Campinas: Universidade Estadual de Campinas - Faculdade de Educação, 2005

ROSAR, M. F. F., KRAWCZYK, N. R. Diferenças da homogeneidade: elementos para o estudo da política educacional em alguns países da América Latina. Educação e Sociedade, Campinas, v. 22, n. 75, Aug. 2001

SENADO FEDERAL, Síntese das audiências públicas para votação do PNE 20102020 , http://www.senado.gov.br/comissoes/CE/documentos/SinteseAudienciasPublicas.pdf. Acesso em 12/12/2013

SIQUEIRA, V.A. O recrutamento e a seleção dos professores pós-municipalização do ensino no municipaio de Jundiaí. Dissertação de mestrado. São Paulo: PUC-SP, 2006 SOARES, J.F. Índice de desenvolvimento da Educação de São Paulo - IDESP: bases metodológicas. São Paulo em Perspectiva. São Paulo, v. 23, n. 1, p. 29-41, jan./jun. 2009

SOARES et al. Exclusão intraescolar nas escolas públicas brasileiras: um estudo com dados da prova Brasil 2005, 2007 e 2009. Brasília: Unesco - Representação no Brasil. Série Debates ED Nº 04 - abril de 2012. ISSN 2236-2843

SOARES, J.F. \& ALVES, M.T.G. Efeitos de escolas e municípios na qualidade do ensino fundamental. São Paulo: Cadernos de Pesquisa v. 43, n. 149, Agosto, 2013

SOUSA, S.C. Desafios para construção da autonomia dos sistemas municipais de ensino de Catanduva, Lins e Mauá. Dissertação de Mestrado. Marília: Faculdade de Filosofia e Ciências da Universidade Estadual Paulista "Julio de Mesquita Filho", Campus de Marília, 2005.

SOUZA, C. (1996). Reinventando o poder local: limites e possibilidades do federalismo e da descentralização. São Paulo: São Paulo em Perspectiva - Fundação Seade, v.10/ nº.3/ Jul-Set 1996

(2004) Governos locais e gestão de políticas sociais universais. São Paulo: São Paulo em Perspectiva - Fundação Seade, v.18/ nº.2/ Abr-Jun 2004

SOUZA, D.B. \& FARIA. L.C.M. Reforma do Estado, Descentralização e Municipalização do Ensino no Brasil: A Gestão Política dos Sistemas Públicos de Ensino Pós-LDB 9.394/96. Rio de Janeiro: Ensaio: Avaliação e Políticas Públicas em Educação, v.12, n.45, p. 925-944, out./dez. 2004

TEIXEIRA, A. Condições para a reconstrução educacional brasileira. Rio de Janeiro: Revista Brasileira de Estudos Pedagógicos, v.18, n.49, $1953 . \quad$ p.3-12. http://www.bvanisioteixeira.ufba.br/. Acesso em 10/01/2014.

A municipalização do ensino primário. Rio de Janeiro: Revista Brasileira de Estudos Pedagógicos, v.27, n.66, abr./jun. 1957. p.22-43. http://www.bvanisioteixeira.ufba.br/. Acesso em 10/01/2014. 
THE ECONOMIST. Brazil takes off: Now the risk for Latin America's big success story is hubris. London: 12 de novembro de 2009

2013

Brazil's future: Has Brazil blown it? London: 28 de setembro de

TOCQUEVILLE, A. A democracia na América: leis e costumes de certas leis e certos costumes políticos que foram naturalmente sugeridos aos americanos por seu estado social democrático. Tradução: Eduardo Brandão; Prefácio, bibliografia e cronologia François Furet. - 2a ed. - São Paulo: Martins Fontes, 2005. - (Paidéia)

UNESCO, Global Education Digest 2012 - Opportunities lost: The impact of grade repetition and early school leaving. Quebec: UNESCO Institute for Statistics, 2012. Ref: UIS/2012/ED/SD/08 ISBN: 978-92-9189-120-7

, Meeting Basic Learning Needs - Adopted by the World Conference on Education for All. (Jomtien, Thailand, 5-9 March 1990). Paris, 2000

Education for All: Meeting Our Collective Commitments - Adopted by the World Education Forum (Dakar, Senegal, 26-28 April 2000). Paris, 2000.

Education for All: Is the world on track? EFA Global Monitoring Report, 2002. Paris, 2002

Education for All: Teaching and Learning: Achieving Quality for All. EFA Global Monitoring Report, 2013/14. Paris, 2014

VIEIRA, S.L. A educação nas constituições brasileiras: texto e contexto. Brasília: Revista Brasileira de Estudos Pedagógicos, v. 88, n. 219, p. 291-309, maio/ago. 2007

VIGEVANI, T.; OLIVEIRA, M. CINTRA, R. Política externa no período FHC: a busca de autonomia pela integração. Tempo soc. [online]. 2003, vol.15, n.2, pp. 31-61. ISSN 0103-2070. http://dx.doi.org/10.1590/S0103-20702003000200003.

VIGEVANI, T. CEPALUNI, G. A política externa de Lula da Silva: a estratégia da autonomia pela diversificação. Contexto int. [online]. 2007, vol.29, n.2, pp. 273-335. ISSN 0102-8529. http://dx.doi.org/10.1590/S0102-85292007000200002.

\section{Bibliografia consultada}

ADRIÃO, T. et al . As parcerias entre prefeituras paulistas e o setor privado na política educacional: expressão de simbiose?.Campinas: Educação e Sociedade, v. 33, n. 119, junho de 2012

ARELARO, Lisete Regina Gomes. O ensino fundamental no Brasil: avanços, perplexidades e tendências. Campinas: Educação e Sociedade, v. 26, n. 92, outubro de 2005 
ARRETCHE, M. Federalismo e centralização no Brasil. Rio de Janeiro: Editora FGV, Editora Fiocruz, 2012.

BROOKE, N. SOARES, J.F. (Orgs.) Pesquisa em Eficácia Escolar: origem e trajetórias. Tradução Cleusa Brooke e Rômulo Monte-Alto. Belo Horizonte: Ed. UFMG, 2008.

MINISTÉRIO DAS RELAÇÕES RXTERIORES. Relatório http://www.itamaraty.gov.br/temas/balanco-de-politica-externa-2003-2010/resumoexecutivo

SENA MARTINS, P. Fundeb, Federalismo e Regime de Colaboração. Campinas: Ed. Autores Associados; Brasília: Faculdade de Educação da Universidade de Brasília, 2011.

PORTELA, R. Da universalização do ensino fundamental ao desafio da qualidade: uma análise histórica. Campinas: Educaão e Sociedade, vol. 28, n.100 - Especial. p. 661-690. Out, 2007

PORTELA, R., SANTANA, W. (Orgs.) Educação e federalismo no Brasil: combater as desigualdades, garantir a diversidade. Brasília: UNESCO, 2010. 300 p. ISBN: 97885-7652-114-3

SCHWARTZMAN, S., COX, C. Políticas Educacionais e Coesão Social: uma agenda latino-americana. Tradução Micheline Christophe e Roberta Caldas. Rio de Janeiro: Elsevier; São Paulo: IFHC, 2009.

SOUZA, C. Federalismo e descentralização na Constituição de 1988: processo decisório, conflitos e alianças. Rio de Janeiro: Instituto Universitário de Pesquisas do Rio de Janeiro. DADOS - Revista de Ciências Sociais, Vol. 44, n³, pp. 513 a 560, 2001

Políticas Públicas: uma revisão da literatura. Porto Alegre: Sociologias Programa de Pós-Graduação em Sociologia - UFRGS, Dez 2006, nº16, pg 20-45. ISSN 1517-4522.

Regras e contexto: as reformas da Constituição de 1988. Rio de Janeiro: DADOS - Revista de Ciências Sociais, Vol. 51, nº4, pp. 791 a 823. , 2008

\section{Bases de dados}

INSTITUTO BRASILEIRO DE GEOGRAFIA E ESTATÍSTICA:

Brasil, Município por Município - Disponível em : http://www.ibge.gov.br/cidadesat/topwindow.htm?1;

Brasil, Estado por Estado - Disponível em: http://www.ibge.gov.br/estadosat/;

Séries Estatísticas - Disponível em:

http://seriesestatisticas.ibge.gov.br/series.aspx?vcodigo=POP22\&sv=32\&t=populacaogrupos-idade-populacao-presente-residente. Vários acessos.

http://downloads.ibge.gov.br/downloads_estatisticas.htm. Vários acessos. 
Estatísticas do Séc. XX http://seculoxx.ibge.gov.br/populacionais-sociais-politicas-eculturais/busca-por-temas/educacao. Varios acessos.

INSTITUTO NACIONAL DE ESTUDOS E PESQUISAS EDUCACIONAIS ANÍSIO TEIXEIRA:

Estatísticas do IDEB: http://portal.inep.gov.br/web/portal-ideb/planilhas-paradownload. Vários acessos.

Sinópses estatísticas da educação básica: http://portal.inep.gov.br/basica-censoescolar-sinopse-sinopse

Sinópses estatísticas da educação superior: http://portal.inep.gov.br/superiorcensosuperior-sinopse

ORGANISATION FOR COOPERATION AND ECONOMIC DEVELOMENT

Programme for International Student Evaluation. Disponível em: http://www.oecd.org/statistics/.

THE WORLD BANK

World Bank's Open Data - http://databank.worldbank.org/data/home.aspx e http://data.worldbank.org/data-catalog. Acesso em 30/11/2012 


\section{Anexos}

Anexo 1: Lista dos países da América Latina e sua participação no Pisa

\begin{tabular}{|c|c|c|c|c|}
\hline $\begin{array}{c}\text { Países da América } \\
\text { do Sul + México }\end{array}$ & População alvo & $\begin{array}{l}\text { \% de alunos } \\
\text { não elegíveis }\end{array}$ & $\begin{array}{c}\% \text { de alunos } \\
\text { abaixo do nível } 2 \\
\end{array}$ & $\begin{array}{c}\% \text { de alunos } \\
\text { acima do nível } 5\end{array}$ \\
\hline Argentina & 688434 & 7,5 & 51,6 & 1,0 \\
\hline Bolívia & \multicolumn{4}{|c|}{ Não participa do PISA } \\
\hline Brasil & 3292022 & 19,4 & 49,6 & 1,3 \\
\hline Chile & 290056 & 8,5 & 30,6 & 1,3 \\
\hline Colômbia & 893057 & 34,8 & 47,1 & 0,6 \\
\hline Equador & \multicolumn{4}{|c|}{ Não participa do PISA } \\
\hline Guiana & \multicolumn{4}{|c|}{ Não participa do PISA } \\
\hline México & 2151771 & 33,8 & 40,1 & 0,4 \\
\hline Paraguai & \multicolumn{4}{|c|}{ Não participa do PISA } \\
\hline Peru & 585567 & 16,2 & 64,8 & 0,5 \\
\hline Suriname & \multicolumn{4}{|c|}{ Não participa do PISA } \\
\hline Uruguai & 53801 & 19,6 & 41,9 & 1,8 \\
\hline Venezuela & \multicolumn{4}{|c|}{ Não participa do PISA } \\
\hline Posição do Brasil & $1^{\mathrm{a}}$ posição & $4^{\mathrm{a}}$ posição & $5^{\mathrm{a}}$ posiç̧ão & $3^{\mathrm{a}}$ posição \\
\hline
\end{tabular}

Fonte: PISA 2009 Results: What Students Know and Can Do: Student Performance in Reading, Mathematics and Science (Volume I). Tabulação própria. 
Anexo 2 - Mapa da divisão político-administrativa do Estado de São Paulo

Mapa 1

Divisão Político-Administrativa

Regiōes Administrativas, Regiōes de Governo e Regiōes Metropolitanas

2003
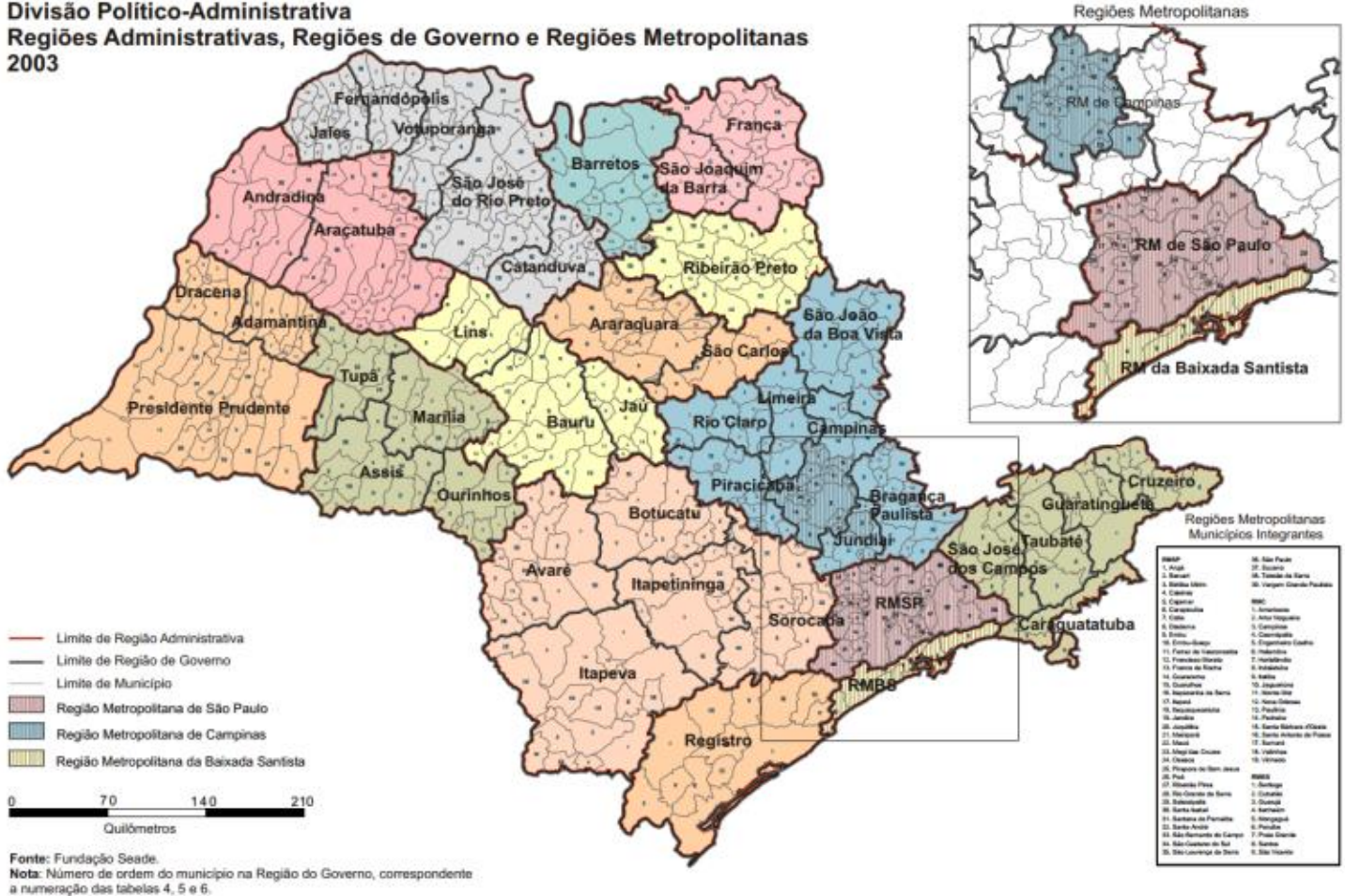

Anexo 3 - Mapa da divisão administrativa da Secretaria de Estado de Educação

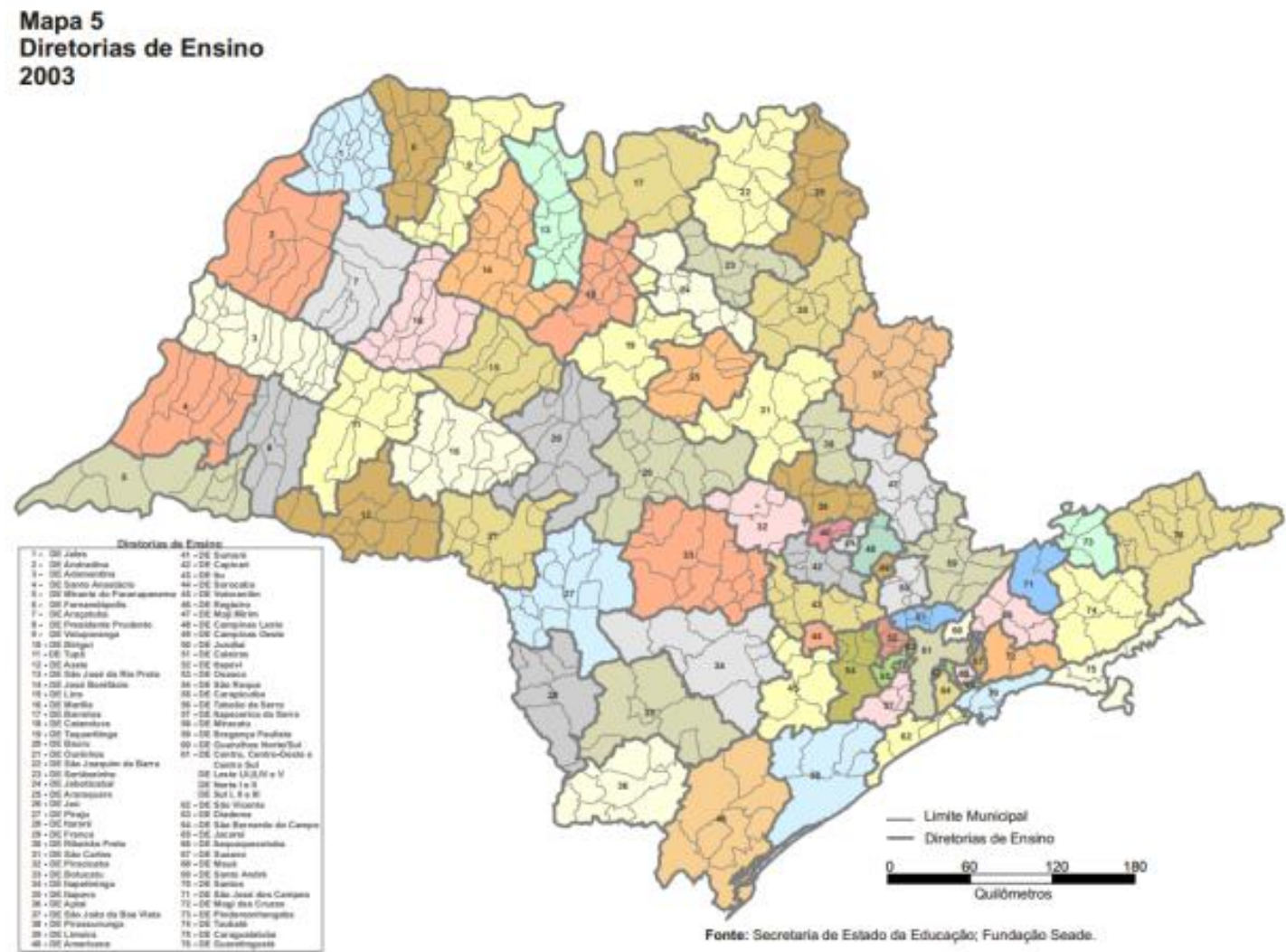


Anexo 4 - Quadro de classificação de proficiência SARESP

Níveis do Sistema de Avaliação da Aprendizagem de São Paulo - Saresp de Desempenho para Leitura e para Matemática, por Série

Estado de São Paulo - 2008

\begin{tabular}{|c|c|c|c|c|c|c|}
\hline \multirow{2}{*}{ Nível do Saresp } & \multicolumn{3}{|c|}{ Desempenho para Leitura } & \multicolumn{3}{|c|}{ Desempenho para Matemática } \\
\hline & $4^{\mathrm{a}}$ Série EF & $8^{a}$ Série EF & $3^{\circ}$ Ano EM & $4^{\mathrm{a}}$ Série EF & $8^{a}$ Série EF & $3^{\circ}$ Ano EM \\
\hline Abaixo do básico & $<150$ & $<200$ & $<250$ & $<175$ & $<225$ & $<275$ \\
\hline Básico & Entre 150 e 200 & Entre 200 e 275 & Entre 250 e 300 & Entre 175 e 225 & Entre 225 e 300 & Entre 275 e 350 \\
\hline Adequado & Entre 200 e 250 & Entre 275 e 325 & Entre 300 e 375 & Entre 225 e 275 & Entre 300 e 350 & Entre 350 e 400 \\
\hline Avançado & Acima de 250 & Acima de 325 & Acima de 375 & Acima de 275 & Acima de 350 & Acima de 400 \\
\hline
\end{tabular}

Fonte: Secretaria de Estado da Educação. 
Anexo 5: Lista dos municípios de cada grupo de análise

\begin{tabular}{|c|c|c|c|c|}
\hline & Grupo 1 & Grupo 2 & Grupo 3 & Grupo 4 \\
\hline \multirow[t]{11}{*}{ A } & Adolfo & Alfredo Marcondes & Altair & Alto Alegre \\
\hline & Águas de São Pedro & Aspásia & & Angatuba \\
\hline & Alumínio & & & Aparecida D'oeste \\
\hline & Álvares Machado & & & Aramina \\
\hline & Analândia & & & Aspásia \\
\hline & Anhembi & & & \\
\hline & Araçariguama & & & \\
\hline & Araçoiaba da Serra & & & \\
\hline & Arapeí & & & \\
\hline & Areias & & & \\
\hline & Areiópolis & & & \\
\hline \multirow[t]{8}{*}{ B } & Bananal & Bastos & Barretos & Bady Bassitt \\
\hline & Barrinha & Borborema & Bebedouro & Balbinos \\
\hline & Barueri & & & Bastos \\
\hline & Boa Esperança do Sul & & & Bom Jesus Dos Perdoes \\
\hline & Boituva & & & Boraceia \\
\hline & Borebi & & & \\
\hline & Buri & & & \\
\hline & Buritizal & & & \\
\hline \multirow[t]{14}{*}{$\mathrm{C}$} & Cajobi & Campinas & Cajobi & \\
\hline & Campos do Jordão & Carapicuíba & & \\
\hline & Canas & & & \\
\hline & Cândido Rodrigues & & & \\
\hline & Canitar & & & \\
\hline & Capela do Alto & & & \\
\hline & Cássia dos Coqueiros & & & \\
\hline & Cedral & & & \\
\hline & Cerquilho & & & Cerquilho \\
\hline & Cesário Lange & & & Cosmorama \\
\hline & Colina & & Colina & \\
\hline & Colômbia & & Colômbia & \\
\hline & Corumbataí & & & \\
\hline & Cristais Paulista & & & \\
\hline $\mathrm{D}$ & Dumont & Dobrada & & Dolcinópolis \\
\hline \multirow[t]{3}{*}{$E$} & Elisiário & & Embaúba & Espirito Santo Do Pinhal \\
\hline & Emilianópolis & & & Estrela D'oeste \\
\hline & Estiva Gerbi & & & \\
\hline
\end{tabular}




\begin{tabular}{|c|c|c|c|c|}
\hline & Grupo 1 & Grupo 2 & Grupo 3 & Grupo 4 \\
\hline \multirow[t]{4}{*}{$\mathrm{F}$} & & & & Fartura \\
\hline & Fernando Prestes & & & Fernando Prestes \\
\hline & & & & Floreal \\
\hline & Flora Rica & Florínia & & Florida Paulista \\
\hline \multirow[t]{5}{*}{$\mathrm{G}$} & Guapiaçu & Gastão Vidigal & Guaíra & \\
\hline & Guará & Guarantã & Guaraci & \\
\hline & Guaraci & & & \\
\hline & Guariba & & & \\
\hline & Guatapará & & & \\
\hline $\mathrm{H}$ & Holambra & Herculândia & & Herculândia \\
\hline \multirow[t]{11}{*}{1} & Ibirá & lacri & & Iacri \\
\hline & Icém & Itaberá & & Ilha Solteira \\
\hline & Igarapava & Itaóca & & Indaiatuba \\
\hline & Ilha Comprida & Itobi & & Itaju \\
\hline & Ilhabela & & & Itapolis \\
\hline & Ipaussu & & & \\
\hline & Iperó & & & \\
\hline & Ipuã & & & \\
\hline & Itajobi & & & \\
\hline & Itatiba & & & \\
\hline & Ituverava & & & \\
\hline \multirow[t]{7}{*}{$J$} & Jaborandi & & Jaborandi & Jales \\
\hline & Jaguariúna & & & \\
\hline & Jambeiro & & & \\
\hline & Jardinópolis & & & \\
\hline & Jeriquara & & & \\
\hline & Joanópolis & & & Joanópolis \\
\hline & Jumirim & & & \\
\hline \multirow[t]{3}{*}{$\mathrm{L}$} & Lavínia & & & \\
\hline & Lindóia & & & \\
\hline & Luís Antônio & & & \\
\hline \multirow[t]{5}{*}{$\mathrm{M}$} & Mairinque & Macaubal & Monte Castelo & Macaubal \\
\hline & Miguelópolis & Mauá & & Matao \\
\hline & Mombuca & Monções & & Mirassol \\
\hline & Monte Alegre do Sul & & & \\
\hline & Motuca & & & \\
\hline \multirow[t]{6}{*}{$\mathrm{N}$} & Narandiba & & & \\
\hline & Nova Campina & & & \\
\hline & Nova Europa & & & \\
\hline & Nova Independência & & & \\
\hline & Novais & & & \\
\hline & Nuporanga & & & \\
\hline \multirow[t]{4}{*}{$\mathrm{O}$} & Orindiúva & & Olímpia & \\
\hline & Orlândia & & & \\
\hline & Oscar Bressane & & & Oscar Bressane \\
\hline & Ouro Verde & & & Ouro Verde \\
\hline \multirow[t]{11}{*}{$\mathrm{P}$} & Palestina & Poloni & Pirangi & Pedreira \\
\hline & Paraíso & Presidente Alves & & Piracaia \\
\hline & Paranapanema & & & Pracinha \\
\hline & Pardinho & & & Presidente Alves \\
\hline & Pedra Bela & & & \\
\hline & Pinhalzinho & & & \\
\hline & Pirapora do Bom Jesus & & & \\
\hline & Potim & & & \\
\hline & Potirendaba & & & \\
\hline & Pradópolis & & & \\
\hline & Presidente Bernardes & & & \\
\hline Q & Quadra & & & \\
\hline \multirow[t]{2}{*}{$\mathrm{R}$} & Restinga & Ribeira & & Ribeirao Do Sul \\
\hline & Ribeirão Corrente & Rinópolis & & Ribeirao Pires \\
\hline
\end{tabular}

